ORNL/ER-69

\author{
Environmental Restoration Division \\ ORNL Environmental Restoration Program
}

\title{
Groundwater Quality Monitoring Well Installation for Upper Waste Area Grouping 2 at Oak Ridge National Laboratory, Oak Ridge, Tennessee
}

\section{J. A. Mortimore}

T. A. Lee

Date Issued-September 1994

Prepared for

\section{U.S. Department of Energy}

Office of Environmental Restoration and Waste Management under budget and reporting code EW 20

Environmental Restoration and Waste Management Programs Oak Ridge National Laboratory

Oak Ridge, Tennessee 37831-6285 managed by

MARTIN MARIETTA ENERGY SYSTEMS, INC.

for the

U.S. DEPARTMENT OF ENERGY

under contract DE-AC05-84OR21400 


\section{DISCLAIMER}

This report was prepared as an account of work sponsored by an agency of the United States Government. Neither the United States Government nor any agency Thereof, nor any of their employees, makes any warranty, express or implied, or assumes any legal liability or responsibility for the accuracy, completeness, or usefulness of any information, apparatus, product, or process disclosed, or represents that its use would not infringe privately owned rights. Reference herein to any specific commercial product, process, or service by trade name, trademark, manufacturer, or otherwise does not necessarily constitute or imply its endorsement, recommendation, or favoring by the United States Government or any agency thereof. The views and opinions of authors expressed herein do not necessarily state or reflect those of the United States Government or any agency thereof. 


\section{DISCLAIMER}

Portions of this document may be illegible in electronic image products. Images are produced from the best available original document. 


\section{Author Affiliations}

J. A. Mortimore is a staff project manager with the Environmental Restoration Program, Oak Ridge National Laboratory, Martin Marietta Energy Systems, Incorporated. T. A. Lee is a hydrogeologist with Ogden Environmental and Energy Services Co., Inc. (formally ERC Environmental and Energy Services Company). 


\section{CONTENTS}

EXECUTIVE SUMMARY $\ldots \ldots \ldots \ldots \ldots \ldots \ldots \ldots \ldots \ldots \ldots \ldots \ldots \ldots$

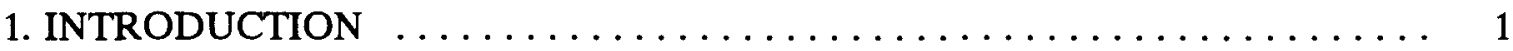

1.1 THE WAG CONCEPT $\ldots \ldots \ldots \ldots \ldots \ldots \ldots \ldots \ldots \ldots \ldots \ldots \ldots \ldots \ldots$

1.2 DESCRIPTION OF UPPER WAG $2 \ldots \ldots \ldots \ldots \ldots \ldots \ldots \ldots \ldots$

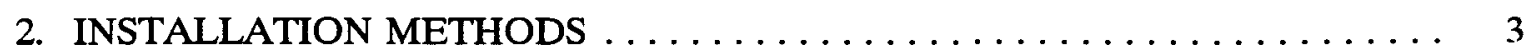

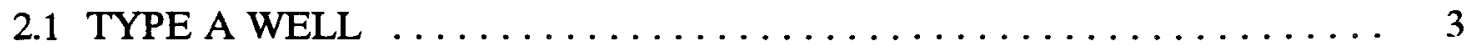

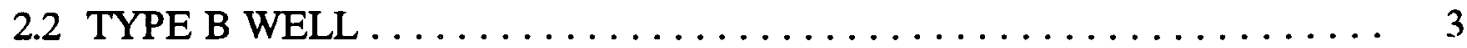

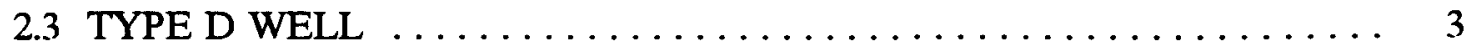

3. ENVIRONMENTAL, HEALTH, AND SAFETY REQUIREMENTS $\ldots \ldots \ldots 6$

4. FIELD SUPPORT $\ldots \ldots \ldots \ldots \ldots \ldots \ldots \ldots \ldots \ldots \ldots \ldots \ldots \ldots \ldots \ldots$

5. DRILLING RECORDS $\ldots \ldots \ldots \ldots \ldots \ldots \ldots \ldots \ldots \ldots \ldots \ldots \ldots$

6. WELL DEVELOPMENT $\ldots \ldots \ldots \ldots \ldots \ldots \ldots \ldots \ldots \ldots \ldots \ldots \ldots$

7. SAMPLING DURING INSTALLATION $\ldots \ldots \ldots \ldots \ldots \ldots \ldots \ldots \ldots, 10$

8. SPECIAL NOTES ON INSTALLATION AND DEVELOPMENT $\ldots \ldots \ldots \ldots 11$

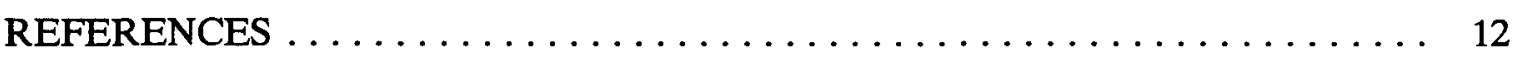

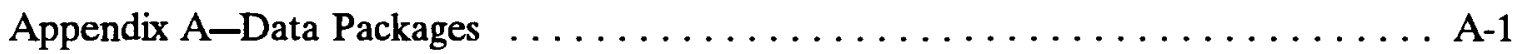

Appendix B-Operating Instructions for Handling Water and Cuttings from Well Drilling and Development of Groundwater Quality

Monitoring Wells ... 


$$
\text { , . }
$$




\section{EXECUTIVE SUMMARY}

This report documents the drilling and installation of seven groundwater quality monitoring (GQM) wells on the perimeter of Upper Waste Area Grouping (WAG) 2. Upper WAG 2 is composed of portions of White Oak Creek (WOC), Melton Branch, two of Melton Branch's tributaries, and the floodplains surrounding these water bodies. The WOC section of the subject site begins at the confluence of WOC and Melton Branch and extends 0.62 mile upstream to the 7500 bridge. The Melton Branch portion of the site also begins at the confluence of WOC and Melton Branch and extends eastward 0.88 mile upstream. The wells at Upper WAG 2 were drilled and developed between December 1989 and October 1990. These wells were installed to characterize and assess the WAG in accordance with applicable Department of Energy, state, and Environmental Protection Agency regulatory requirements.

Well design and placement were performed by Martin Marietta Energy Systems, Inc., (Energy Systems) geologic staff and their subcontractors. The wells were drilled, installed, and developed by a drilling subcontractor (Geotek Engineering, Inc.) under contract with Energy Systems. The contract was administered by the Energy Systems Engineering Division for the Environmental Restoration (ER) Program. Hydrogeologic support was provided by an environmental subcontractor [ERC Environmental and Energy Services, Inc. (ERCE)] under contract with Energy Systems. (As of January 1, 1992, ERCE started operating under the name of Ogden Environmental and Energy Services Co., Inc.) This contract was administered by ER Division staff. Radiation protection and industrial hygiene support for the drilling program was provided by Energy Systems staff or their subcontractors.

The wells at Upper WAG 2 were drilled with auger or air rotary rigs. Depending upon the hydrogeologic conditions present at each proposed well location, one of three basic installation methods was utilized. Detailed procedures for well construction were specified by the Engineering Division to ensure that the wells would provide water samples representative of the aquifer. In order to ensure conformance with the specifications, Energy Systems Construction Engineering and ERCE provided continuous oversight of field activities.

The purpose of the well installation program was to install GQM wells for groundwater characterization at Upper WAG 2. Data packages produced during installation activities by the ERCE hydrogeologists are an important product of the program. These packages document the well drilling, installation, and development activities and provide valuable data for well sampling and WAG characterization. The forms contained in the packages include predrilling and postdrilling checklists, drilling and construction logs, development and hydraulic conductivity records, and quality control-related documents. 


\section{INTRODUCTION}

The purpose of this report is to document the drilling and installation of the groundwater quality monitoring (GQM) wells on the perimeter of Upper Waste Area Grouping (WAG) 2. Installation of GQM wells was required at Oak Ridge National Laboratory (ORNL) for regulatory compliance. Data obtained from these wells will be used to characterize and assess groundwater quality at the perimeter of each WAG in accordance with applicable Department of Energy, state, and Environmental Protection Agency regulatory requirements. The wells in Upper WAG 2 were drilled and developed between December 1989 and October 1990.

\subsection{THE WAG CONCEPT}

At ORNL, the solid waste management units (SWMUs) include solid waste storage areas (SWSAs), pipelines, spill sites, buildings, ponds, and experimental test sites that are considered to be potential sources of contamination. The SWMUs are further grouped into WAGs, the boundaries of which are defined by watersheds that contain contaminants derived from similar assemblages of operating facilities and SWMUs. Basically, the wells are located on or near these boundaries to determine whether contaminants have been released from the WAGs.

\subsection{DESCRIPTION OF UPPER WAG 2}

WAG 2 consists of two SWMUs, (1) White Oak Lake and the embayment below White Oak Dam above the Clinch River and (2) WOC and its tributaries and their respective floodplains. These surface water bodies constitute the major drainage system for ORNL and its outlying support facilities. For the sake of better management of data, production of usable graphics, and presentation of concise descriptive information, WAG 2 has been divided into upper and lower sections.

Upper WAG 2 shares boundaries with WAG 1, WAG 4, WAG 5, WAG 7, and WAG 8 [Fig 1, map pocket (MMES map \#C3E20004A121, Rev. B]. It receives drainage from these WAGs and from WAG 9. Each of the above listed WAGs contains SWMUs that have operating histories spanning as much as 40 years. During this 40 -year period, surface runoff and groundwater transport of contaminants from the adjoining WAGs have occurred. Many of these contaminants have accumulated within the floodplain and streambed sediments of Upper WAG 2.

In addition to serving as a collection point for the more mobile contaminants, Upper WAG 2 contains two inactive waste management units and one active unit. The oldest inactive waste management unit is the remnants of a diked area at the bottom of a former impoundment. The impoundment was located on the WOC floodplain south of the 7500 bridge and served as an intermediate settling basin for ORNL plant discharges from 1943 to 1944. Late in 1944, the dike failed and the impoundment was drained, but many of the contaminated sediments remain.

The second inactive waste management unit in Upper WAG 2 is a short section of 
abandoned intermediate-level liquid waste (ILLW) line that crosses beneath the floodplain. This portion of the ILLW line is located just north of the confluence of WOC and Melton Branch. The short section of line was part of the ILLW delivery system that was extended from the pits and trenches area in WAG 7 to the first hydrofracture site in WAG 5. The line was eventually abandoned in favor of an alternate route, and no leaks are reported to have occurred on this short section of ILLW line.

The only active SWMU in Upper WAG 2 is a short section of ILLW line located about $300 \mathrm{ft}$ east of the confluence of WOC and Melton Branch. This section of ILLW line is part of the alternate route mentioned above. It is used to transfer ILLW to storage tanks at the new hydrofracture facility.

Overall, the contamination in Upper WAG 2 is thought to be derived chiefly from non-point sources in adjoining WAGs. As a result, the distribution of contaminants in Upper WAG 2 is believed to be diffuse, with locally elevated contamination zones resulting from the principal discharge points for surface water and ground water from the adjoining WAGs. Seven monitoring wells were drilled in Upper WAG 2 in the floodplain of White Oak Creek and its tributaries (Fig. 1, map pocket). 


\section{INSTALLATION METHODS}

Four basic types of well construction were used during the GQM installation program at ORNL. Schematic diagrams of these four well types are shown on Fig. 2. Three of the four types (A, B, and D) were used at Upper WAG 2. These three types are described in Sects. 4.1 through 4.3. The specific details of each well installation are included in the monitoring well narratives (Appendix A). The specifications for drilling and well installation were provided in Construction Specifications for Monitoring Wells Installation Construction Project, K-4491G-G1. ${ }^{1}$ The proposed well design criteria for the Upper WAG 2 wells can be found in the report Preliminary Geohydrologic Site Characterization and Proposed Water Quality Well Locations for WAG 11 and Upper WAG 2, ORNL/RAP/Sub-87/SB189/1. ${ }^{2}$ The actual completion data for Upper WAG 2 are listed in Table 1.

\subsection{TYPE A WELL}

The type A well boring is drilled to total depth with solid-stem augers. On completion, the boring is bailed with a steel bailer to remove drill cuttings. The well is completed with 2in.-diam stainless steel screen, casing, and a silt trap. Stainless steel centralizers are positioned at the top of the screen and every $20 \mathrm{ft}$ along the casing. A sandpack is poured into the annular space from total depth to $1 \mathrm{ft}$ above the screen. Pelleted bentonite is poured into the annular space to create a 2 -ft seal above the sandpack. The top of the bentonite seal is measured with a stainless steel weighted tape. The annular space above the bentonite seal is then grouted to the surface through a tremie pipe.

\section{TYPE B WELL}

The first step in drilling the type B wells is to auger a boring from the surface to a depth of $4 \mathrm{ft}$. A steel diverter casing is installed, and the annulus is grouted to the surface. The boring is then deepened with a tricone air rotary bit to a minimum depth of $10 \mathrm{ft}$ total and $2 \mathrm{ft}$ into bedrock. Next, a steel surface casing is installed and grouted into place. The air rotary method is used to drill the boring to the required depth. The well is completed with 4-in.-diam stainless steel screen and casing. A sandpack, a bentonite seal, and grout are installed in the annular space by the same procedures as used for the Type A well.

\subsection{TYPE D WELL}

A type $\mathrm{D}$ well is a type $\mathrm{A}$ well with a diverter casing. If the auger encounters refusal before reaching total depth on a type $\mathrm{A}$ well, the boring was reamed to refusal with a larger auger, and a steel diverter casing is installed. The annulus is grouted up to surface level. The boring is deepened to total depth with a tricone air rotary bit, and the well is completed with 2-in.-diam stainless steel screen and casing. A sandpack, a bentonite seal, and grout are installed in the annular space by the same procedures as those used for the type A well. 


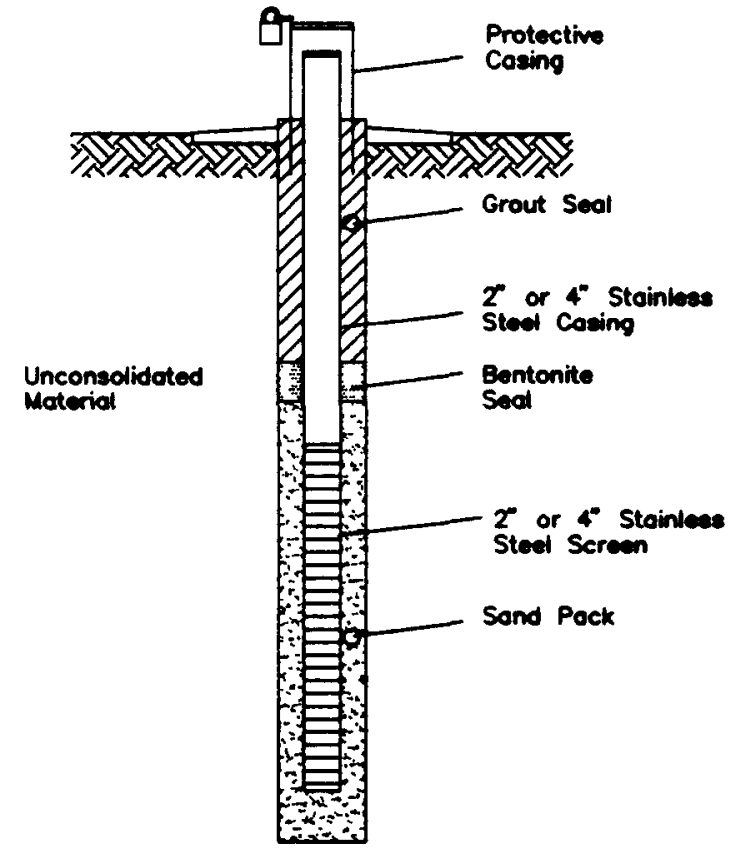

TYPE A WELL

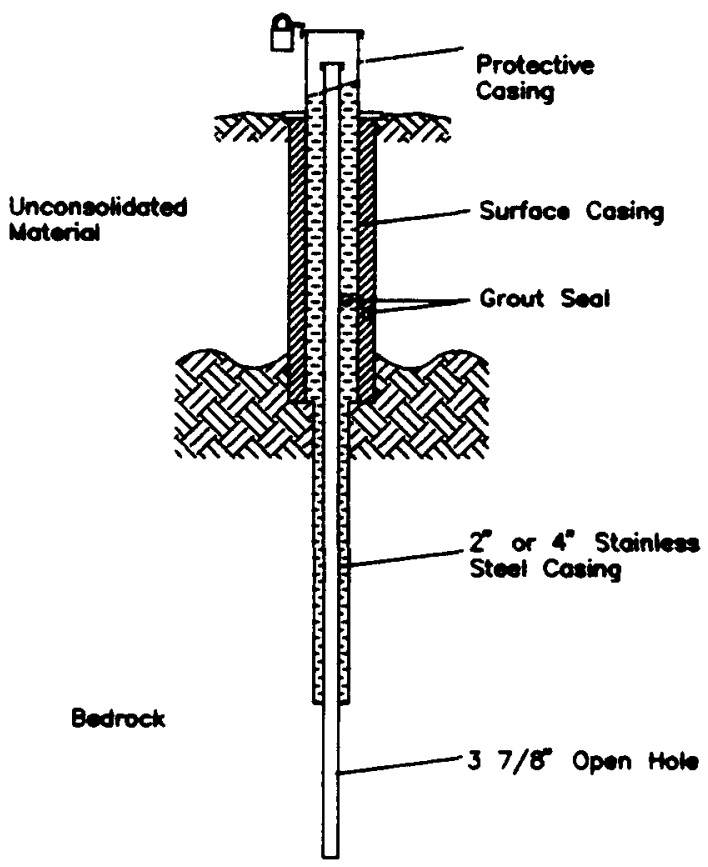

TYPE C WELL

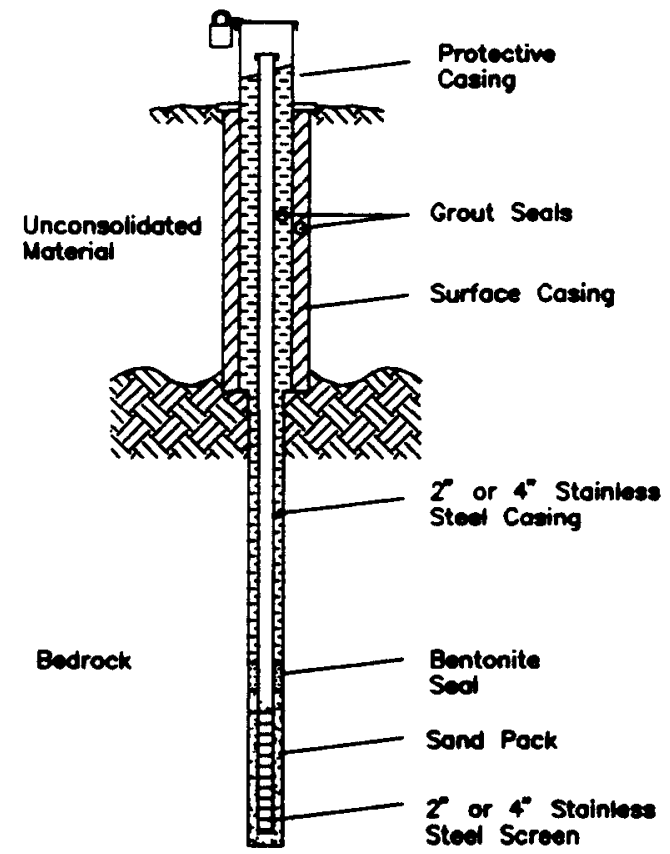

TYPE B WELL

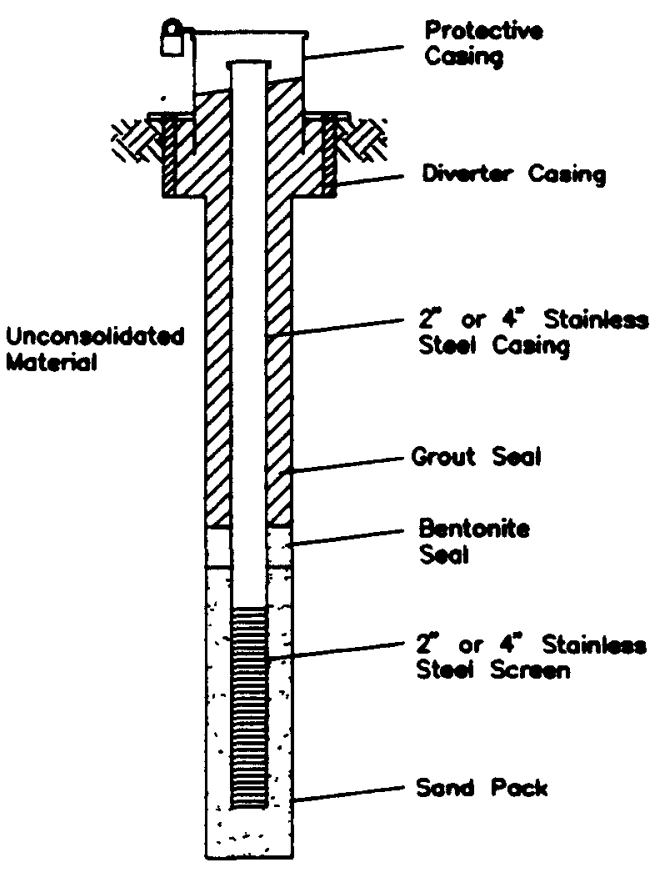

TYPE D WELL

Fig. 2. The four types of well construction used during the Groundwater Quality Monitoring Well Installation Program at Oak Ridge National Laboratory. 
Table 1. Actual completion data for Upper WAG 2

\begin{tabular}{cccccc}
\hline Well & $\begin{array}{c}\text { Depth } \\
\text { clean to } \\
(\mathrm{ft})^{a}\end{array}$ & $\begin{array}{c}\text { SST casing } \\
\text { diam(in.) }\end{array}$ & $\begin{array}{c}\text { Well } \\
\text { type }\end{array}$ & $\begin{array}{c}\text { Screened } \\
\text { interval } \\
(\mathrm{ft})\end{array}$ & $\begin{array}{c}\text { Water } \\
\text { level } \\
(\mathrm{ft})^{b}\end{array}$ \\
\hline 1150 & 16.0 & 2 & A & $5.8-15.8$ & -5.0 \\
1151 & 20.0 & 2 & D & $4.8-19.8$ & -2.1 \\
1152 & 14.9 & 2 & D & $4.7-14.7$ & -5.8 \\
1153 & 18.0 & 2 & D & $7.8-17.8$ & -4.1 \\
1154 & 15.3 & 2 & D & $5.1-15.1$ & -3.9 \\
1155 & 23.0 & 2 & D & $12.8-22.8$ & -6.6 \\
1156 & 21.3 & 2 & D & $11.0-21.0$ & -7.9 \\
\hline
\end{tabular}

${ }^{a}$ Total drilled depth may vary from clean-out depth. See data packages (Appendix A)

${ }^{b}$ Predevelopment water level; depth measured from ground surface. (Negative is below surface; positive, above surface.) 


\title{
3. ENVIRONMENTAL, HEALTH, AND SAFETY REQUIREMENTS
}

\begin{abstract}
All well drilling at Upper WAG 2 was conducted in accordance with procedures outlined in the document Health, Safety, and Environmental Protection Procedures for Excavating Operations, ORNL/M-116/R1 ${ }^{3}$. Among the procedures set forth by this document is a system for rating proposed well locations according to the degree of probability that contamination will be encountered. This rating determined the level of personnel training required and health and safety coverage to be used during drilling.

The Superfund Amendment Reauthorization Act required still more stringent health and safety measures for personnel working in waste areas. These workers were required to have $40 \mathrm{~h}$ of training for hazardous duty through an ORNL-approved course, $8 \mathrm{~h}$ of refresher training each year, $8 \mathrm{~h}$ of supervisor's training for field supervisors, a whole-body count, baseline urinalysis, respirator testing and fitting, and medical monitoring. Personnel were also required to take a construction-worker training course covering the fundamentals of radioactivity and other types of contamination as well as the other hazards that could be encountered at ORNL. The workers were taught the proper procedures to follow in the event of an on-site emergency.
\end{abstract}

Special procedures were used during drilling. The ground surface at all drill sites was covered with polyethylene sheeting to prevent contact between the tools and the ground. The sheeting would also have protected the environment in the event of a hydraulic fluid release. Containment was required for all drill cuttings produced. During augering, a metal pan was used to hold cuttings until a health physicist (HP) could determine their proper disposition. During air rotary drilling, cuttings were diverted from the borehole to a special containment box designed by Martin Marietta Energy Systems, Inc. (Energy Systems). The box is a 500-gal, trailer-mounted tank with demister elements and high-efficiency particulate air filters at the air exhaust. In order that appropriate methods of disposal could be determined, the tank contents were checked by the HP for radioactive contamination and by the site hydrogeologist for volatile organics. The operating instructions that were followed for determining disposition of the cuttings and water produced during drilling and development are in Appendix B. 


\section{FIELD SUPPORT}

The construction contractor Geotek Engineering Company, whose contract began in May 1989, installed the GQM wells in Upper WAG 2. ORNL Engineering administered the drilling contract through Energy Systems Procurement. The management organization chart for the project is in the Task Management Plan for Groundwater Quality Monitoring Well Installation, ORNL/RAP/LTR-88/28. ${ }^{4}$

The hydrogeologic support and installation record keeping were supplied through a contract with ERC Environmental and Energy Service Company (ERCE), formerly EDGe/MCI. An ERCE representative was present during all activities that affected the quality of the wells and advised Energy Systems on well construction. ORNL personnel or their subcontractors provided HP and industrial hygiene support.

Construction engineering support was supplied by Energy Systems personnel. Drawings, excavation permits, well placement in the field, and as-built surveying and calculations were done by the Energy Systems Civil and Architectural Department or by their subcontractor, Adams Craft Herz Walker Engineering Company. The as-built survey coordinates and elevations are on the well installation/completion form for each well (Appendix A). The as-built coordinates are also summarized in a table on the well location map (Fig. 1). 


\section{DRILLING RECORDS}

A complete data package has been compiled for each of the seven GQM wells drilled in Upper WAG 2. These data packages are in numerical order in Appendix A. All original records are retained in the Environmental Restoration (ER) Division Records Control Data Base. The forms included in each well data package are listed here in the order in which they appear in the package:

1. monitor well narrative,

2. predrilling checklist for monitoring wells,

3. decontamination checklist for drilling equipment,

4. well log,

5. well installation/completion form,

6. monitoring well materials certification,

7. post-well completion checklist,

8. monitoring well development form,

9. monitoring well development progress,

10. hydraulic conductivity calculation,

11. nonconformance report (if necessary), and

12. chain of custody forms.

Three additional forms used in the field by the site hydrogeologist but not included in the published data packages are the monitoring well progress form, the hydraulic conductivity test field sheet, and the containment box checklist. These forms are also kept in the ER Division Records Control Data Base. 


\section{WELL DEVELOPMENT}

Wells were developed by pumping. Wells with high initial turbidities were surged beforehand with a workover rig and a stainless steel surge block to facilitate removal of the sediment from the well. The contents of the wells were then pumped out using Geoguard airlift pumps and oilless air compressors. Development of a well was considered complete when at least three well volumes had been removed and the turbidity was measured at 5 nephelometric turbidity units (NTUs) or less. Several wells had turbidity ratings higher than 5 NTUs even after extensive pumping, but, in order to prevent the pulling in of groundwater from too far away, a maximum limit of 30 to 35 well volumes was determined by Energy Systems hydrogeologists to be the upper limit that should be removed. The contents of the wells were pumped out using Geoguard development pumps. The two-stage Geoguard pumps were converted to dedicated bladder pumps for sampling after development was complete. All development water was contained and disposed of according to the operating instructions in Appendix B.

Of the seven wells in Upper WAG 2, six wells had turbidity ratings of less than or equal to 5 NTUs. The number of well volumes removed ranged from 17.4 to 52.1, with an average of 29.9. The procedure for measuring turbidity described in ORNL/RAP/LTR-88/28 ${ }^{4}$ was replaced with a more accurate method. While the previously used method depended on a visual comparison of the sample with prepared standards, the new method employs the ColeParmer turbidimeter, which measures NTUs by passing a lens-focused light beam through a test tube filled with a water sample. A photosensor detects the intensity of the exiting light beam, and an analog scale on the instrument displays the turbidity of the sample. 


\section{SAMPLING DURING INSTALLATION}

The ERCE hydrogeologist took samples of soil, rock, and drilling water during well installation and submitted them to the ORNL Analytical Chemistry Division for chemical analysis. Soil and rock samples were taken from the unsaturated and saturated zones. Samples of drilling water were collected from the water pump discharge on the drill rig when drilling with the air rotary took place. All samples were transferred using chain-of-custody forms, which are included in the data packages. The sampling procedures are explained in ORNL/RAP/LTR-88/28. ${ }^{4}$ Soil samples were collected from each single well and from one well of each well pair. A drilling-water sample was collected from each air-rotary-drilled boring.

Analyses for 31 chemical elements, gross alpha, gross beta, and ${ }^{40} \mathrm{~K}$ were routinely performed on the soil and water samples. The results from these analyses are found in the ER Division Records Control Data Base. 


\section{SPECIAL NOTES ON INSTALLATION AND DEVELOPMENT}

During the drilling of the GQM wells in Upper WAG 2, wells 1152 and 1156 were determined by HP to be Class II locations (moderate probability of encountering contamination). No measurable RAD over background was encountered at either location. 


\section{REFERENCES}

1. Engineering Division, Construction Specifications for Monitoring Wells Installation Construction Project, Rev. 2, K-4491G-G1, Martin Marietta Energy Systems, Inc., Oak Ridge National Laboratory, Oak Ridge, Tenn., August 1988.

2. Engineering, Design and Geosciences Group, Inc., Preliminary Geohydrologic Site Characterization and Proposed Water Quality Well Locations For WAG 11 and Upper WAG 2, ORNL/RAP/Sub/87-SB189/1, Martin Marietta Energy Systems, Inc., Oak Ridge National Laboratory, Oak Ridge, Tenn., September 1987.

3. Environmental Compliance and Health Protection Division, Health, Safety, and Environmental Protection Procedures for Excavating Operations, ORNL/M-116/R1, Martin Marietta Energy Systems, Inc., Oak Ridge National Laboratory, Oak Ridge, Tenn., March 3, 1988.

4. J. A. Mortimore, Task Management Plan for Groundwater Quality Monitoring Well Installation, ORNL/RAP/LTR-88/28, Martin Marietta Energy Systems, Inc., Oak Ridge National Laboratory, Oak Ridge, Tenn., February 1988. 
Appendix A

\section{Data Packages}



ERC / EDGE

Environmental

and Energy

Services Co.

MONITORING WELL PROGRAM

WEZ DATA NARRATVE

WELL NO. 1150

\subsection{General Information}

\subsection{Nel1 Location}

Monitoring well number 1150 is located in Upper WAG 2 . It is 750 feet due south of the intersection of Lagoon Road and Melton Valley Road. The location is shown on ORNL drawing number C3E20004A075. Survey coordinates for this well are N 19,298.5495, E 29,620.0985 (X-10 grid) or latitude $35^{\circ}-55^{\prime}-05.58^{\prime \prime}$ and longitude $84^{\circ}-18^{\prime}-56.76^{\prime \prime}$. Coordinate data were provided by Martin Marietta Energy systems. The method used for conversion from x-10 grid to Tennessee-Lambert state Plane Coordinates came from the publication "Tennessee Valley Authority Data Services Branch and Mapping Services Branch, Oak Ridge, Tennessee, DOE Plant Control, November 6, 1985, Field Book: EsS3115, pp. 1-20." The latitude and longitude were calculated by Adams Craft Herz Walker Engineering, Inc., using methods from the U.S. Coast and Geodetic survey Publication 62-4, "State Plane Coordinates by Automatic Data Processing."

\subsection{Drilling Information}

Well number 1150 was drilled by Geotek Engineering Company. A Schramm Rotadrill rig was used to drill this boring for monitor well installation under operation of George Akins with the assistance of James Shelton. Drilling commenced on December 14, 1989, and was finished on December 14, 1989. Paragraph 2.4.1 includes a detailed discussion of the well installation and a well schematic is included on the well installation/completion 
ERC / EDGE

Environmental

and Energy

Services Co.
MONITORING HELL PROGRAM

WEZL DATA NARRATVE

WEZL NO._L 1150

form. A synopsis of the drilling activity follows. This information was typed directly from field notes and was edited only when necessary for clarification.

12-14-89 The rig was mobilized to the staked location and set up on plastic sheeting. split spoon samples were taken from surface to 10.8 feet at refusal. The boring was deepened to 16.3 feet using a 6-inch auger. set stainless steel casing with sand pack and bentonite seal. The rig was moved from location.

12-15-89 The casing was grouted into place with 1.0 sack of cement.

This well was logged by ERC Environmental and Energy Services Co., Inc., hydrogeologist Timothy A. Lee. All well construction materials and supplies were from Martin Marietta Energy systems approved batches. The batch origin of individual items is shown on the included Monitoring Well Materials Certification form.

\subsection{Technical Information}

\subsection{Decontamination Procedures}

The drilling rig, down hole tools, surface casing, stainless steel screen, stainless steel casing, centralizers, and stainless steel silt trap underwent the cleaning decontamination procedures outlined in the drilling specifications (Release specific Technical 
Directions for Regulatory Compliance Monitoring Wells Phase 1, Oak Ridge National Laboratory, Oak Ridge, W.O. K-4147, April 1987, pgs. 2-4). A checklist of the cleaned materials is included with this data package.

\subsection{8}

The Rome Formation underlies the northern portion of Upper WAG 2 and consists of variegated shale and siltstone with beds of gray, fine grained sandstone. The Conasauga Group underlies the southern portion of Upper WAG 2 and is divided into five members. They are from north to south, the Pumpkin Valley Shale, Rutledge Limestone, Rogersville Shale, Maryville Limestone, and Nolichucky shale. These rocks have undergone extensive deformation and contain many folds and faults resulting in varying strike and dips. The regional strike is 56 degrees northeast with dips of about 30 degrees to the southeast. The White Oak creek tear fault is in Upper WAG 2. Displacement varies from 40 feet up to 350 feet.

\section{3 sample collection}

One soil sample was collected during drilling, placed in an I-CHEM specialty cleaned glass container, sealed and submitted to Sample Receiving, Analytical Chemistry Division, Bldg. 4500s, ORNL. A chain of custody form for this soil sample is included with this data package. Soil sample 1150S01 was collected in the split spoon interval from 8.0 feet to 8.5 feet on December 14,1989 . 
A bulk density soil sample was collected from the split spoon sample interval from 4.5 feet to 4.8 feet. The sample was measured and weighed, and a bulk density of $2.10 \mathrm{grams} / \mathrm{cm}^{3}$ was calculated.

\subsection{Installation and Development}

\subsubsection{Installation}

This was a Type A well. A 6-inch diameter boring was split spooned and augered from ground surface to a total depth of 16.3 feet. A 2-inch diameter stainless steel screen with threaded bottom cap was installed from 5.8 feet to 16.0 feet. A 2-inch diameter stainless steel casing was installed above the screen from 5.8 feet to 1.74 feet above ground surface. A sand pack was then tremied into the annular space from 4.6 feet to 16.0 feet, with a 1.9-foot bentonite pellet seal poured into the annular space above the sandpack from 2.7 feet to 4.6 feet. The annular space from the top of the bentonite seal to the surface was tremie-grouted with a cement/bentonite slurry. A detailed schematic of the well is included on the well installation/completion form.

\section{4 .2 Nell Development}

Well number 1150 was developed to remove drill cuttings, silt, and other fines. The monitoring well was developed using a Geoguard pump with an air compressor. All pumps were cleaned prior to use according to specified cleaning procedures (see Paragraph 2.1). The well was developed until a measured total of 150 gallons of water had been 


\begin{tabular}{|l|l|}
\hline $\begin{array}{l}\text { ERC / EDGE } \\
\text { Environmental } \\
\text { and Energy } \\
\text { Services Co. }\end{array}$ & $\begin{array}{c}\text { MONITORING WEU PROGRAM } \\
\text { WEU DATA NARRA JIE } \\
\text { WELL NO. I150 }\end{array}$ \\
\hline
\end{tabular}

evacuated and the clarity of the discharge water was approved by the company representative. The final turbidity value measured at completion was $>100$ NTU's. A development form showing the exact method of development and other pertinent data is appended.

\subsubsection{Installation of Dedicated Monitoring well Pump}

After the well was developed, a Geoguard Model No. 5614 dedicated monitoring well pump was installed on July 17, 1990, at a depth of 13.6 feet below ground surface. These pumps are decontaminated at American Sigma and are sent prepackaged. A copy of the pump certification is kept on file at ORNL.

\subsection{Hydraulic Conductivity Testing}

Well number 1150 was tested for the determination of hydraulic conductivity of the aquifer in the vicinity of the well screen. This was accomplished by instantaneously adding a known quantity of water to the monitoring well and measuring the recovery of the water level over time. The changing water levels were measured using a Druck 15 psig pressure transducer and an Omnidata Datapod II data recorder. The hydraulic conductivity value of $1.10 \times 10^{-4} \mathrm{~cm} /$ second (shown as permeability on the hydraulic conductivity calculations printout attached) was calculated using the Bouwer and Rice method. A computer printout of the hydraulic conductivity calculations is included in this data package. 


\section{ERC / EDGE}

Environmental

and Enerey

Services Co.

WELL No.1150

\section{PRE-DRILLING CHECKLIST FOR MONITORING WELLS}

PRE-DRILUNG TASKS

1. EXCAVTION PERMIT OBTAINED

2. ALL EQUIPMENT HAS BEEN CLEANED BEFORE DRILLING.

30. SCREEN AND CASING HAVE BEEN WASHED, STEAMED, RINSED WTH DE-IONIZED OR DISTLLED WATER, RINSED WTH ISOPROPN ALCOHOL MRAPPED WTH PROTECTVE COVERING AND STORED OFF THE GROUND.

36. PRE-PACKAGED SCREENS, CASING AND CENTRALIZERS WERE USED.

4. WORK AREA FOR SAMPLE EXAMINATION COVERED WTH CLEAN POL YETHRENE.

5. CLEAN KNIVES, GOVES, SAMPLE JARS AND LABELS ON HAND.

6. POLYETHRENE COVER IN PLACE OVER HOLE.

7. AVR ROTARY COMPRESSED AIR SAMPLED.

RESULT: $N / A$

COMPLIANCE

\begin{tabular}{|c|c|}
\hline \multicolumn{2}{|c|}{ COMPLIANCE } \\
\hline$D A \pi$ & INIRALS \\
\hline $12-14-89$ & 123 \\
\hline $12-14-89$ & $\pi m_{3}$ \\
\hline$N / A$ & $N / A$ \\
\hline
\end{tabular}

$12-14-89$

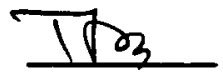

$12-14-89$

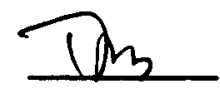

12-14-89

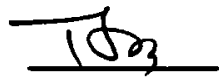

$12-14-89$

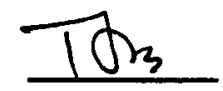

N/A

$N / A$

AODITONAL NOTES/OBSERVA TONS:

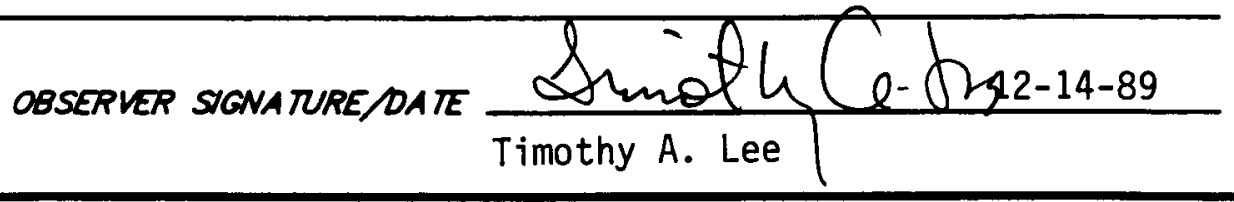




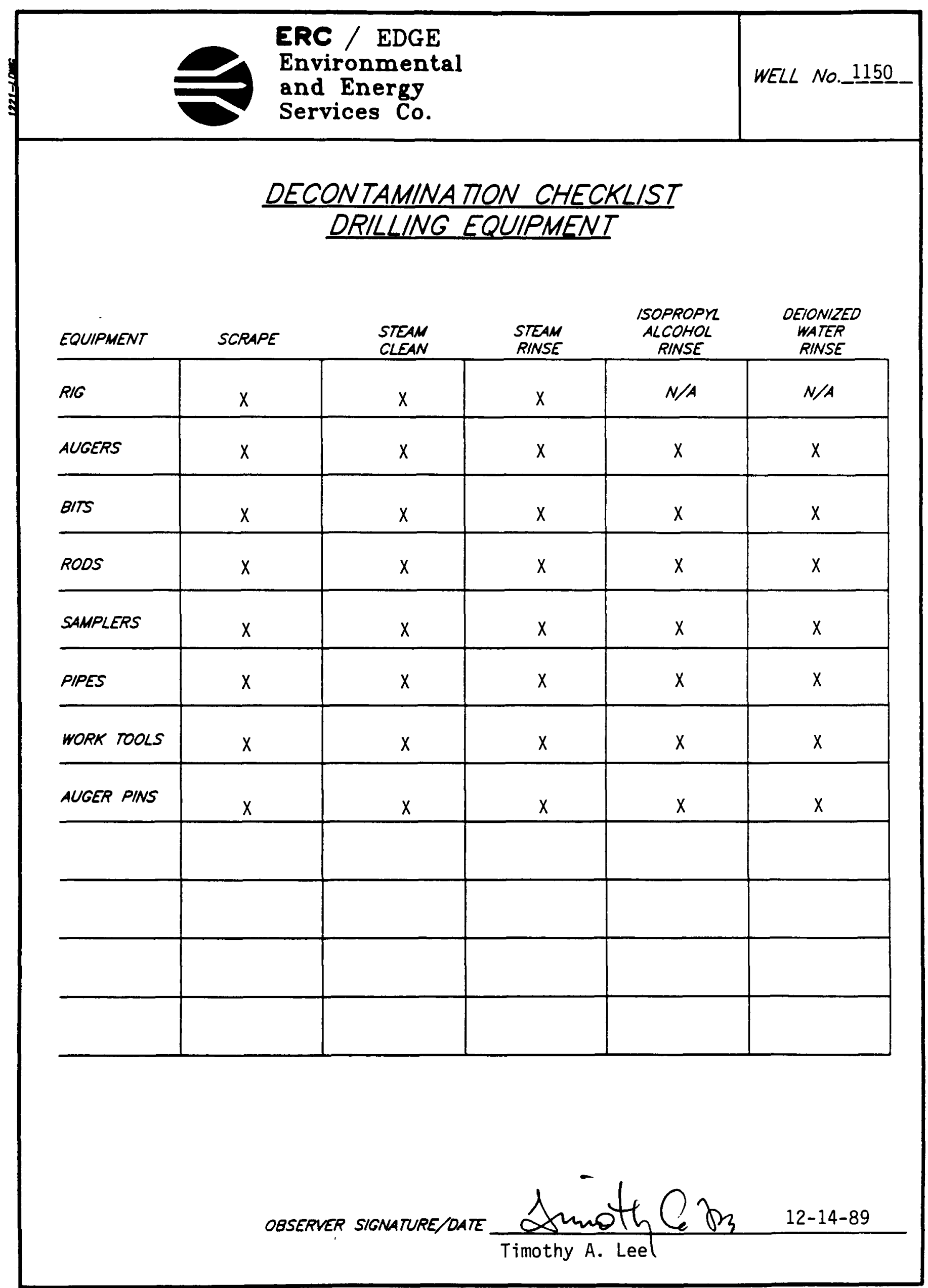

PAGE _ 7 of 19 . 


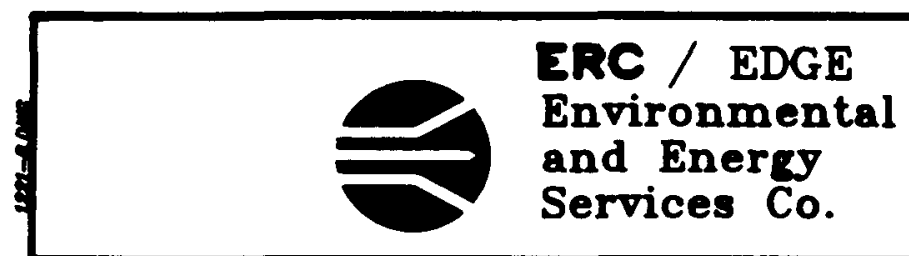

ORNL MONITORING WELL LOG

LOCA TON: Upper WAG 2

ORILLER: George Akins

HELPER: James Shelton

DRILL: Schramin Rotadrill

MPE ORILLNG: Split spoons, augers

No. SAMPLES TAKEN: One

CONTAINMENT TrPE: Plastic, pan

THICKNESS OF SOL (RETUSAL DEPTH): 16.3'

DEPTH DRILLEO IN ROCK:

$0.0^{\prime}$

TOTAL OEPTH OF MELL:

\section{PACE 1 of 2}

DATE: START: $12-14-89$

FINISH: 12-14-89

LOGGED BY: Timothy A. Lee

HEALTH PHISICST: Bill Shinpaugh

LUBRICANT MPE: Green stuff

MPE: SO 11

\begin{tabular}{|c|c|c|c|c|}
\hline \multicolumn{2}{|c|}{$\begin{array}{l}\text { OEPTH } \\
\text { (FEET) }\end{array}$} & $\begin{array}{l}\text { SAMPLE } \\
\text { (NUMBER A } \\
\text { INTERVAL) }\end{array}$ & $\begin{array}{c}\text { PERCENT } \\
\text { RECOVERY } \\
\text { (SPUT SPOONS) }\end{array}$ & SOL BEDROCK OESCRIPTION \\
\hline 0.0 & 1.5 & & Augered & Gravel fill \\
\hline \multirow[t]{2}{*}{1.5} & 3.5 & & $75 \%$ & Clay, moderate yellowish brown, medium dense, \\
\hline & & & & damp, scattered sandstone, reddish brown \\
\hline \multirow[t]{2}{*}{3.5} & 3.8 & & $90 \%$ & Clay, dark yellowish brown, damp, scattered \\
\hline & & & & roots and vegetation \\
\hline \multirow[t]{3}{*}{3.8} & 4.4 & & $90 \%$ & Clay, dark yellowish orange, dry, plastic, \\
\hline & & & & slightly silty, mottled with clay, yellowish \\
\hline & & & & gray, dark streaks \\
\hline \multirow[t]{3}{*}{4.4} & 5.5 & & $90 \%$ & Clay, dark yellowish brown, damp, loose, \\
\hline & & & & slightly silty. Bulk density taken from $4.5^{\prime}$ \\
\hline & & & & $4.8^{\prime}$, Bulk density is $2.10 \mathrm{~g} / \mathrm{cm}^{3}$ \\
\hline \multirow[t]{2}{*}{5.5} & 6.1 & & $50 \%$ & Clay, dark yellowish brown, wet, slightly silty \\
\hline & & & & loose, very soft \\
\hline 6.1 & 6.6 & & $50 \%$ & Clay, light olive gray, moist, loose, soft \\
\hline \multirow[t]{2}{*}{6.6} & 7.5 & & $50 \%$ & Clay, moderate yellowish brown, damp, and shale \\
\hline & & & & olive gray, iron stained \\
\hline \multirow[t]{2}{*}{7.5} & 9.0 & $1150 S 01$ & $90 \%$ & Clay, light olive gray, wet, slightly silty \\
\hline & & $8.0^{\prime}-8.5^{\prime}$ & & \\
\hline \multirow[t]{3}{*}{9.0} & 9.5 & & $100 \%$ & Shale, olive gray to light olive gray, iron \\
\hline & & & & stains \\
\hline & & & & \\
\hline
\end{tabular}




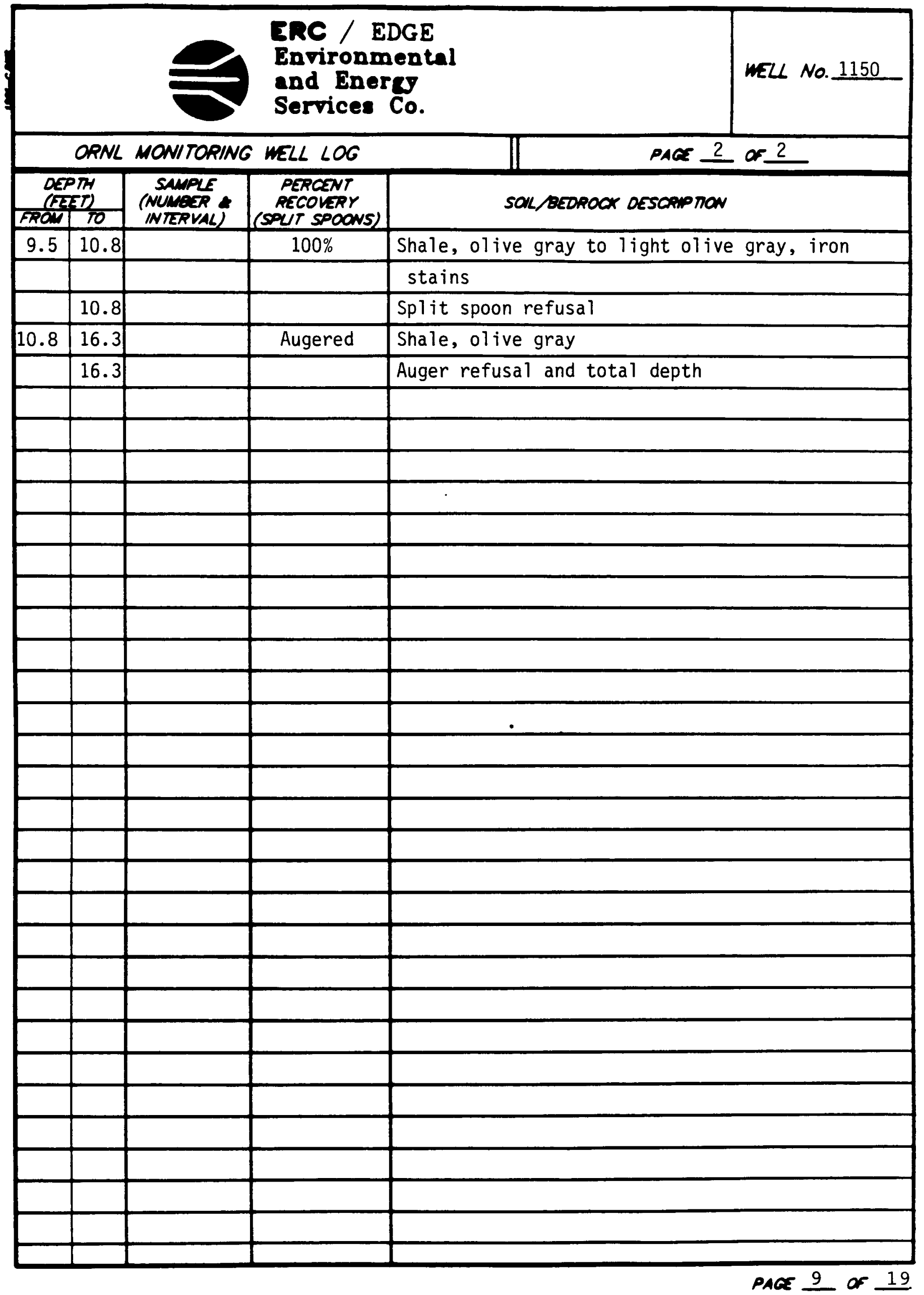




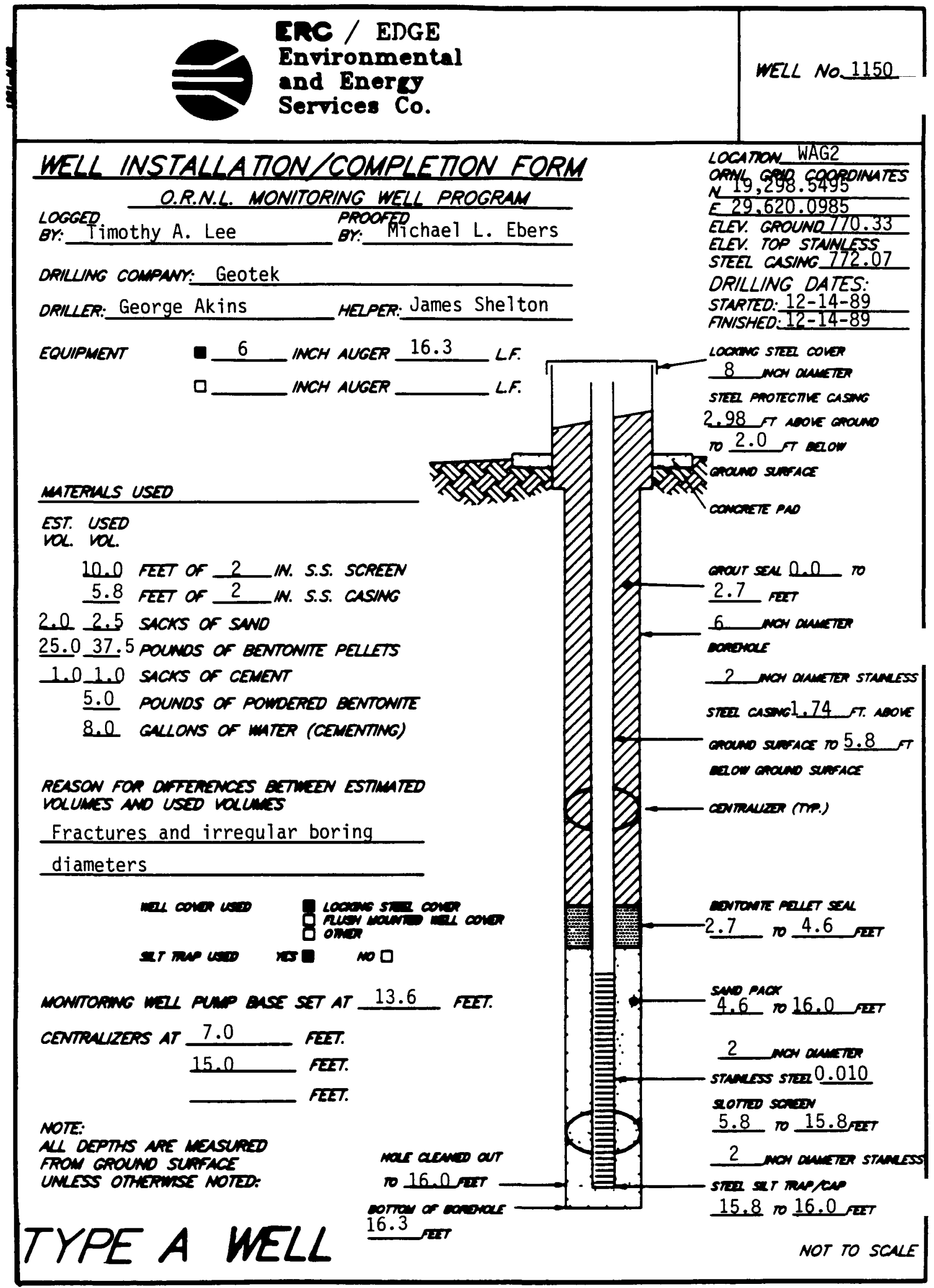

Proe 10 of 19 . 


\section{MONITORING WELL MATERIALS CERTIFICA TION}

ITEM/MATERIAL

DAIE USER

BATCH NUMBER

SANO

BENTONITE

Pellets

Powder

\begin{tabular}{ll}
\hline STAINLESS STEEL SCREEN & (PREPACKAGED \\
\hline STAINLESS STEEL CASING & (PREPACKAGED \\
\hline
\end{tabular}

STAINLESS STEEL CENTRALIZERS (PREPACKAGED

STAINLESS STEEL CAPS

(PREPACKAGED

MONITORING WELL PUMP

(PREPACKAGED

\begin{tabular}{|c|c|c|}
\hline & DATE USER & BATCH NUMBER \\
\hline & $12-14-89$ & 1 \\
\hline \multirow{2}{*}{$\begin{array}{l}\text { ets } \\
\text { der }\end{array}$} & $12-14-89$ & 1 \\
\hline & $12-14-89$ & 3 \\
\hline $\begin{array}{c}\text { YES } \\
\text { NO }\end{array}$ & $12-14-89$ & 2 \\
\hline $\begin{array}{c}\text { YES } \\
\text { NO }\end{array}$ & $12-14-89$ & 2 \\
\hline $\begin{array}{c}\text { VES } \\
\text { NO }\end{array}$ & $12-14-89$ & 2 \\
\hline $\begin{array}{c}\text { VES } \\
\text { NO }\end{array}$ & $12-14-89$ & 2 \\
\hline$\left(\begin{array}{c}\text { YES } \\
\text { NO }\end{array}\right.$ & $07-17-90$ & 7 \\
\hline & $12-14-89$ & 3 \\
\hline & $N / A$ & $N / A$ \\
\hline
\end{tabular}

COMMENTS:

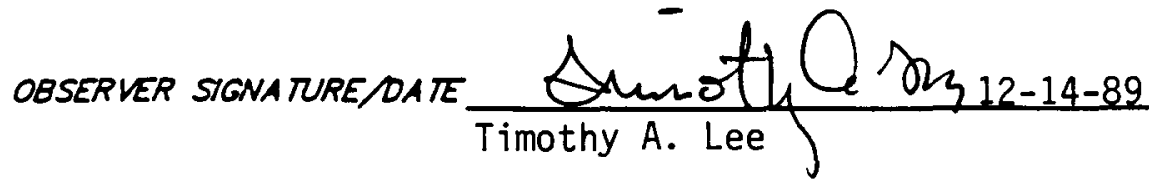

PAGE 11 of 19. 


\section{POST-MELL COMPLETION \\ CHECKLIST}

\section{POST-MELL COMPLETION TASKS}

1. WU SCRAPED FROW AUGERS SAMPLERS ANO ALL OTHER EOUIPIINT.

2. ALL WUO GRON ANG ANO EQUPMENT SORAFWOS MN

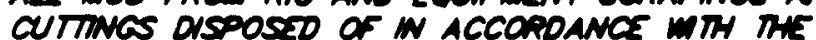
SPECATCA IION PROWOED.

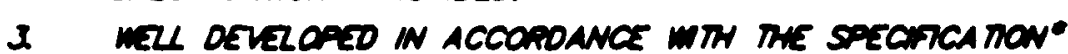
PROMOED ANO OETAKS OF INE OEVZZOPUENT ACIUT PECOAOED.

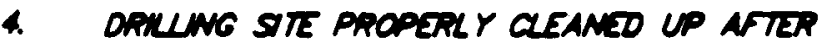
completion of mel INSTALATION.

COMPIIANCE
$\frac{12-14-89}{\text { INITALS }}$
$\frac{\text { 12-14-89 }}{162}$
$\frac{162}{12-14-89}$

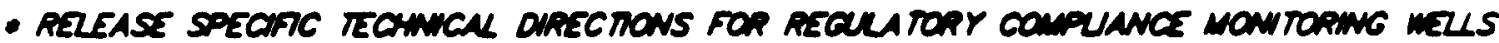

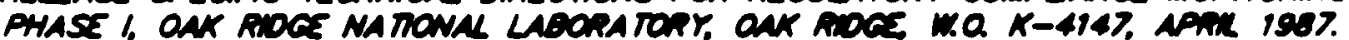
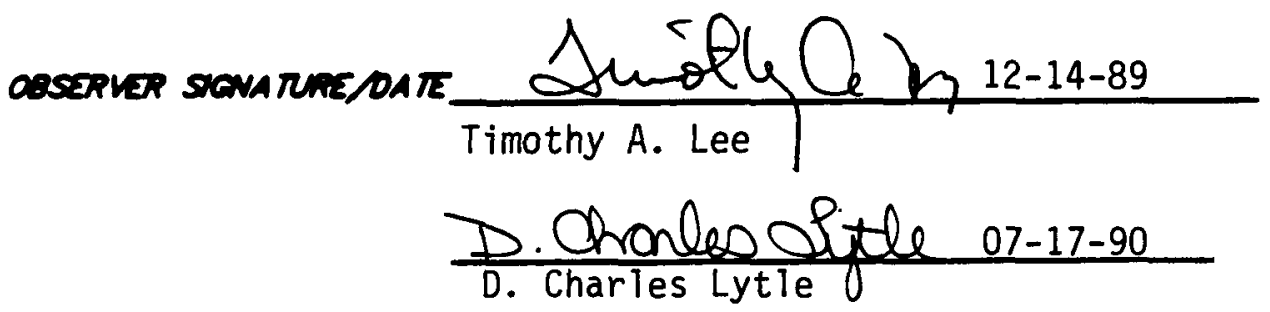
ERCE

Environmental

and Eneres

Services Co.

\section{MONITORING WELL \\ DEVELOPMENT FORM}

DEVELOPMENT DETAILS

MENHOO OF
QEVELORMENT: Surging and pumping

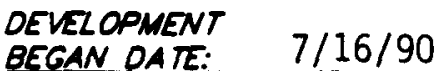

TME:

DEVELOPMENT

ENDING DATE: $\quad 7 / 17 / 90$

DEVELOPMENT

OBSERVED BY:

D. Charles Lytle

ONE WELL VOLUME: 4.5 GALLONS

TOTAL GALLONS PUMPED: 150 TOTAL WEL VOLUMES PUMPED: 33.3

INITAL PH: 8.1

FNAL PH: 8.1

INITAL CONDUCTUTY ( H S/ cm): 466

FNAL CONOUCIVTH ( $\mu S /(\mathrm{cm}): 466$

OESCRIPTION OF INITAL TURBIOITY: MUddy

DESCRIPTION OF FNAL TURBIOITY: Muddy

FNAL MEASURED TURBIDITY: 100 NTU's

WEL APPROVED BY: R.C. Williams MMES

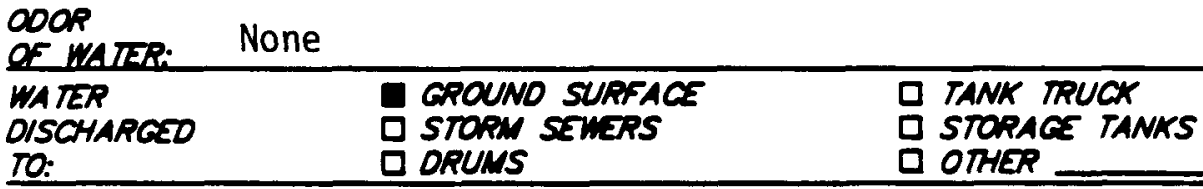

INITAL PRE-DEVEOPNENT

WATER DEPTH: 5.0 feet from ground surface

DEVELOPMENT OBSERVATIONS

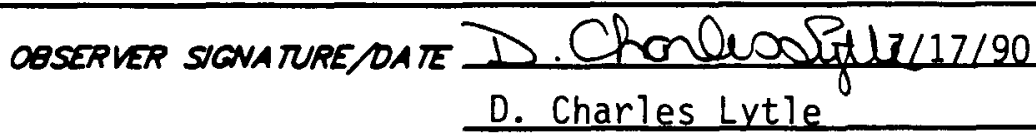




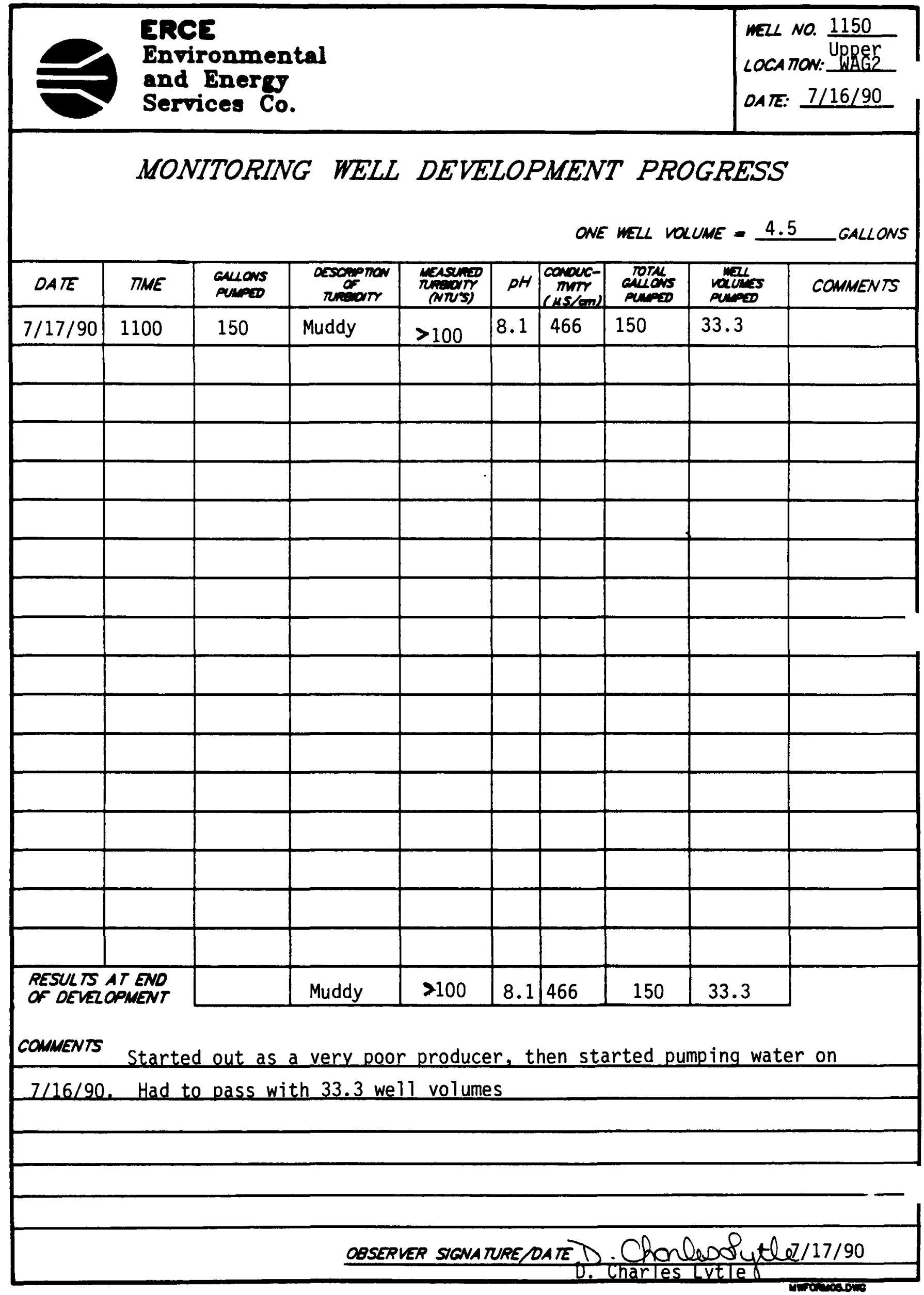

PAGE 14 of 19. 


\section{HYDRAULIC CONDUCTIVTY CALCULATIONS}

PROGRAM SLUGT, VERSION 4.1, NOV. 1986

THIS PROGRAM CALCULATES MEAN TRANSMISSIVITIES FROM

SLUG-TEST DATA BASED ON TWO ANALYTICAL APPROACHES:

(1) METHOD OF COOPER, BREDEHOEFT AND PAPADOPULOS, 1967 (ARTICLE IN VOL.3, NO.1 OF WRR ENTITLED

"RESPONSE OF A FINITE DIAMETER WELL TO AN INSTANTANEOUS CHARGE OF WATER")

(2) METHOD OF BOUWER AND RICE, 1976 (ARTICLE IN

VOL. 12, NO.3 OF WRR ENTITLED

"A SLUG TEST FOR DETERMINING HYDRAULIC CONDUCTIVITY

OF UNCONFINED AQUIFERS WITH COMPLETELY OR PARTIALLY PENETRATING WELLS")

WELL NO.: 1150

DATE OF TEST: $10-29-90$

PROJECT NO.: E221-002

CLIENT: MMES

FITE LOCATION: U. WAG-2

EDGE, INC. FIELD INVESTIGATOR: JAMES W. CARUTHERS

INPUT DATA ARE:

INNER CASING DIAMETER $=2.00$ INCHES

INNER SCREEN OR OPEN-HOLE DIAMETER $=2.00$ INCHES

DIAMETER OF DRILLED HOLE $=6.00$ INCHES

LENGTH OF SCREEN OR INTAKE PORTION $=10.00$ FEET

DEPTH FROM STATIC LEVEL TO BOTTOM OF SCREEN $=11.20$ FEET

THICKNESS OF SATURATED AQUIFER ZONE $=10.00$ FEET

DEPTH TO STATIC WATER LEVEL BELOW REF. POINT $=1.00$ FEET

ESTIMATED POROSITY OF GRAVEL PACK $=.20$

FALLING-HEAD INDEX $=1$ ("1" IF FALLING,"0" IF RISING)

NUMBER OF DEPTH-TIME DATA POINTS = 27

HO WAS COMPUTED FROM INTERCEPT OF PLOT OF LOG(H) VS. TIME

SUCCESSIVE COMPUTED

VALUES FOR HO

(FEET)

1.1307

1.1808 
HYDRAULIC CONDUCTIVTY CALCULATIONS

$\begin{array}{ccc}\text { TIME } & \text { DEPTH TO WATER } & \begin{array}{r}\text { HEAD } \\ \text { (SEC }\end{array} \\ \text { (FEET) } & \\ 10.00 & 4.640 & 3.640 \\ 20.00 & 3.650 & 2.650 \\ 30.00 & 3.240 & 2.240 \\ 40.00 & 2.910 & 1.910 \\ 50.00 & 2.630 & 1.630 \\ 60.00 & 2.430 & 1.430 \\ 75.00 & 2.200 & 1.200 \\ 90.00 & 2.020 & 1.020 \\ 105.00 & 1.870 & .870 \\ 120.00 & 1.750 & .750 \\ 150.00 & 1.540 & .540 \\ 180.00 & 1.410 & .410 \\ 240.00 & 1.260 & .260 \\ 300.00 & 1.170 & .170 \\ 360.00 & 1.140 & .140 \\ 420.00 & 1.120 & .120 \\ 480.00 & 1.090 & .090 \\ 540.00 & 1.080 & .080 \\ 600.00 & 1.060 & .060 \\ 720.00 & 1.040 & .040 \\ 840.00 & 1.040 & .040 \\ 960.00 & 1.040 & .040 \\ 1080.00 & 1.020 & .020 \\ 1200.00 & 1.020 & .020 \\ 1320.00 & 1.020 & .020 \\ 1440.00 & 1.020 & .010 \\ 1560.00 & 1.010 & \end{array}$


HYDRAULIC CONDUCTIVTY CALCULATIONS

METHOD OF BOUWER AND RICE

COMPUTED RESULTS USING DIAMETER OF DRILLED HOLE:

PERMEABILITY $=3.61 \mathrm{E}-06 \mathrm{FT} / \mathrm{SEC}=1.10 \mathrm{E}-04 \mathrm{CM} / \mathrm{SEC}$

TRANSMISSIVITY $=3.61 \mathrm{E}-05 \mathrm{FT} * 2 / \mathrm{SEC}$

COMPUTED RESULTS USING DIAMETER OF CASING AND SCREEN:

PERMEABILITY $=4.80 \mathrm{E}-06 \mathrm{FT} / \mathrm{SEC} \quad=1.46 \mathrm{E}-04 \mathrm{CM} / \mathrm{SEC}$

TRANSMISSIVITY $=4.80 \mathrm{E}-05 \quad \mathrm{FT} * * 2 / \mathrm{SEC}$

PAGE 17 of 19 


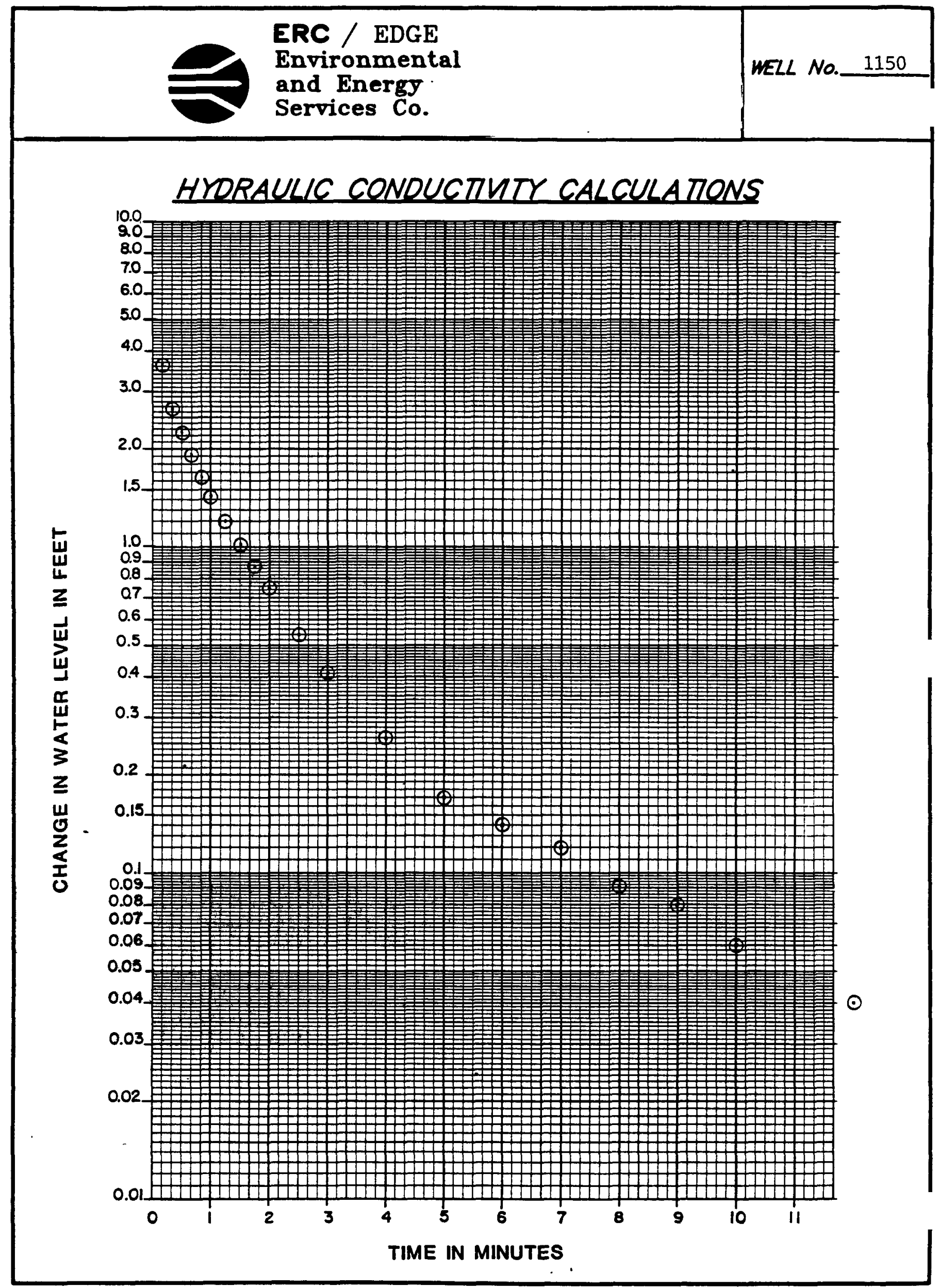

PACE 18 or 19 
1) Gengineering. Design \& Geosciences Group, Inc. 726 Pollisslpp! Parkway

P.0. Box 23010 Knoxvillo, In 37933-1010

CHAIN OF CUSTODY RECORD

FOR

MARTN MARIETTA ENERGY SYSTEMS OAK RIDGE NATIONAL LABORATORY

WELL NO. 1150

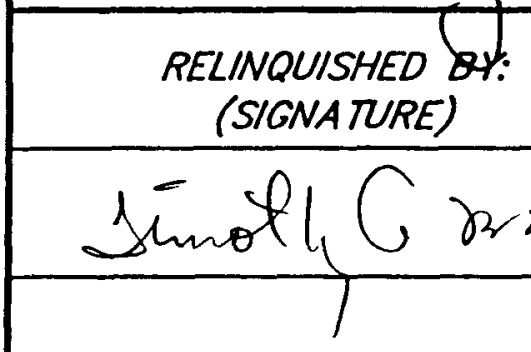

LOCATON: WAG 2
SAMPLE INTERVAL: $8.0^{\prime}$ To $8.5^{\prime}$

OATE:

TYPE OF SAMPLE:

SPLIT SPOON CORES-SOIL

口 AIR ROTARY CUTINGS-ROCK

D AUGER CUTTNGS-SOIL

RECEIVED BY: (SIGNATURE)

\begin{tabular}{|l|l|l|l|}
\hline $12 / 19 / 87$ & 1245 & $E R C$
\end{tabular}

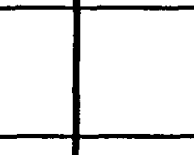

ALL SAMPLES ARE IMMEDIATELY PLACED IN I-CHEM SPECIALTY CLEANED CONTAINERS AND SEALED. REMARKS: 
ERC / EDGE

Environmental

and Energy

Services Co.
MONITORING WELL PROGRAM

WEZL DATA NARRATVE

MEZL NO. 1151

\subsection{General Information}

\subsection{Ne11 Location}

Monitoring well number 1151 is located in Upper WAG 2 . It is along the northeast boundary of Upper WAG 2 , approximately 250 feet southeast of building 7500 . The location is shown on ORNL drawing number C3E20004A075. survey coordinates for this well are $N 18,531.4384$, E $31,761.3675\left(X-10\right.$ grid) or latitude $35^{\circ}-55^{\prime}-11.05^{\prime \prime}$ and longitude $84^{\circ}-18^{\prime}-29.94^{\prime \prime}$. Coordinate data were provided by Martin Marietta Energy Systems. The method used for conversion from $x-10$ grid to Tennessee-Lambert state Plane Coordinates came from the publication "Tennessee Valley Authority Data Services Branch and Mapping Services Branch, Oak Ridge, Tennessee, DOE Plant Control, November 6, 1985, Field Book: Ess-3115, pp. 1-20." The latitude and longitude were calculated by Adams craft Herz Walker Engineering, Inc., using methods from the U.S. Coast and Geodetic Survey Publication 62-4, "state Plane Coordinates by Automatic Data Processing."

\subsection{Drilling Information}

Well number 1151 was drilled by Geotek Engineering Company. A Schramm Rotadrill rig was used to drill this boring for monitor well installation under operation of George Akins with the assistance of James Shelton. Drilling commenced on December 7, 1989, and was finished on December 12, 1989. Paragraph 2.4.1 includes a detailed discussion of the well installation and a well schematic is included on the well installation/completion 
ERC / EDGE

Environmental

and Energy

Services Co.
MONITORING WELL PROGRAM

WEZL DATA NARBATVE

HELL NO. 1151

form. A synopsis of the drilling activity follows. This information was typed directly from field notes and was edited only when necessary for clarification.

12-07-89 The rig was mobilized to the staked location and set up on plastic sheeting.

12-08-89 Split spoon samples were taken from surface to 7.9 feet at refusal. The boring was widened with a 14-inch auger to 3.9 feet and set 10 3/4-inch diverter casing and grouted it into place. the rig was moved from location.

12-12-89 The rig was moved to location and set up. The boring was deepened from 7.9 feet to 20.3 feet using a 7/8-inch rotary air tricone bit into a containment box. Water was heard flowing into well. Therefore, set 2-inch stainless steel screen and casing with sand pack and bentonite seal. The casing was grouted into place with 1 sack of cement.

This well was logged by ERC Environmental and Energy Services Co., Inc., hydrogeologist Timothy A. Lee. All well construction materials and supplies were from Martin Marietta Energy Systems approved batches. The batch origin of individual items is shown on the included Monitoring Well Materials Certification form.

\subsection{Technical Information}

\subsection{Decontamination Procedures}

The drilling rig, down hole tools, surface casing, stainless steel screen, stainless steel casing, 
ERC / EDGE

Environmental

and Energy

Services Co.
MONITORING WELL PROGRAM

WEZL DATA NARRATVE

WELL NO. 1151

centralizers, and stainless steel silt trap underwent the cleaning decontamination procedures outlined in the drilling specifications (Release specific Technical Directions for Regulatory Compliance Monitoring Wells Phase 1, Oak Ridge National Laboratory, Oak Ridge, w.0. K-4147, April 1987, pgs. 2-4). A checklist of the cleaned materials is included with this data package.

\subsection{6e0logy}

The Rome Formation underlies the northern portion of Upper WAG 2 and consists of variegated shale and siltstone with beds of gray, fine grained sandstone. The Conasauga Group underlies the southern portion of Upper WAG 2 and is divided into five members. They are from north to south, the Pumpkin Valley Shale, Rutledge Limestone, Rogersville Shale, Maryville Limestone, and Nolickucky Shale. These rocks have undergone extensive deformation and contain many folds and faults resulting in varying strike and dips. The regional strike is 56 degrees northeast with dips of about 30 degrees to the southeast. The White Oak creek tear fault is in Upper WAG 2. Displacement varies from 40 feet up to 350 feet.

\subsection{Bample Collection}

One soil sample was collected during drilling, placed in an I-CHEM specialty cleaned glass container, sealed and submitted to Sample Receiving, Analytical Chemistry Division, Bldg. 4500S, ORNL. Soil sample 1151501 was collected in the split spoon interval from 6.3 feet to 6.6 feet on December 8, 1989. A drill water sample was collected from the water pump on the drill rig on 
ERC / EDGE

Environmental

and Energy

Services Co.

December 12, 1989. Analytical results for the soil and water samples described above can be obtained from the Remedial Action Program data base at ORNL. Chain of custody forms for these samples are included with this data package.

A bulk density soil sample was collected from the split spoon sample interval from 6.3 feet to 6.6 feet. The sample was measured and weighed, and a bulk density of 2.22 grams $/ \mathrm{cm}^{3}$ was calculated.

The Schramm Rotadrill compressed air was sampled with a cloth filter inserted between drill rods on December 12 , 1989. The sample was examined with an ultraviolet light for the presence of hydrocarbons. The filter showed no detectable signs of hydrocarbons.

\subsection{Installation and Development}

\subsubsection{Installation}

This was a Type D well. A 6-inch diameter boring was split spooned/augered from ground surface to auger refusal ( 7.9 feet). The air rotary method was required to complete the boring to the specified total well depth. Therefore, a 14.0- inch diameter boring was augered from ground surface to 3.9 feet and a 10 3/4-inch diverter casing was installed and grouted. An 8-inch diameter boring was then drilled with an air rotary tricone roller bit from 3.9 to 20.3 feet. A 2-inch diameter stainless steel screen with welded bottom cap was installed from 4.8 to 20.0 feet. A 2-inch diameter stainless steel casing was installed above the screen at 4.8 feet and 
extended 1.80 feet above ground surface. A sandpack was then tremied into the annular space from 3.3 to 20.0 feet, with a 1.6-foot bentonite pellet seal poured into the annular space above the sandpack from 1.7 to 3.3 feet. The annular space from the top of the bentonite seal to the surface was tremie-grouted with a cement/bentonite slurry. A detail of the well is included on the well installation/completion form.

\section{4 .2 We11 Development}

Well number 1151 was developed to remove drill cuttings, silt, and other fines. The monitoring well was developed using a Geoguard pump with an air compressor. All pumps were cleaned prior to use according to specified cleaning procedures (see Paragraph 2.1). The well was developed until a measured total of 495 gallons of water had been evacuated and the clarity of the discharge water was approved by the company representative. The final turbidity value measured at completion was $4.0 \mathrm{NTU}$ 's. A development form showing the exact method of development and other pertinent data is appended.

\subsubsection{Installation of Dedicated Monitoring Well Pump}

After the well was developed, a Geoguard Model No. 5614 dedicated monitoring well pump was installed on June 22 , 1990, at a depth of 18.1 feet below ground surface. These pumps are decontaminated at American sigma and are sent prepackaged. A copy of the pump certification is kept on file at ORNL. 
ERC / EDGE

Environmental

and Energy

Services Co.
MONITORING WELL PROGRAM

WEZL- DATA NARPATVE

\subsection{Eydraulic conductivity Testing}

Well number 1151 was tested for the determination of hydraulic conductivity of the aquifer in the vicinity of the well screen. This was accomplished by instantaneously adding a known quantity of water to the monitoring well and measuring the recovery of the water level over time. The changing water levels were measured using a Druck 15 psig pressure transducer and an Omnidata Datapod II data recorder. The hydraulic conductivity value of $2.87 \times 10^{-5} \mathrm{~cm} /$ second (shown as permeability on the hydraulic conductivity calculations printout attached) was calculated using the Bouwer and Rice method. A computer printout of the hydraulic conductivity calculations is included in this data package. 


\section{PRE-DRILLING CHECKLIST FOR MONITORING WELLS}

RRE-DRILUNG TASKS

1. EXCAVTION PERMIT OBTAINED

\begin{tabular}{|c|c|}
\hline \multicolumn{2}{|c|}{ COMPIIANCE } \\
\hline$\frac{D A \pi E}{12-8-89}$ & ZALS \\
\hline $12-8-89$ & $b_{2}$ \\
\hline$N / A$ & $N / A$ \\
\hline
\end{tabular}

30. SCREEN AND CASING HAVE BEEN WASHED, STEAMED, RINSED WIH DE-IONIZED OR DISTLLED WATER, RINSED WTH ISOPROPN ALCOHOL, WRAPPED WTH PROTECTVE COVERING AND STORED OFF THE GROUND.

36. PRE-PACKAGED SCREENS, CASING AND CENTRALIZERS $12-12-89$

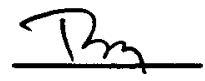
WERE USED.

4. WORK AREA FOR SAMPLE EXAMINATION COVERED WTH CLEAN POL YETHRENE.

5. CLEAN KNIVES, GOVES, SAMPLE JARS AND LABELS ON HAND.

6. POL YETHRENE COVER IN PLACE OVER HOLE.
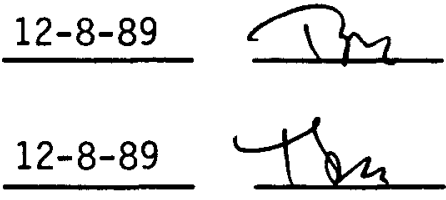

7. AIR ROTARY COMPRESSED AIR SAMPLED.

RESULTS: Showed no signs of hydrocarbons under ultraviolet light

ADDIMONAL NOTES/OBSERVATIONS:

OBSERVER SIGNATURE/OATE

Timothy A. Lee 


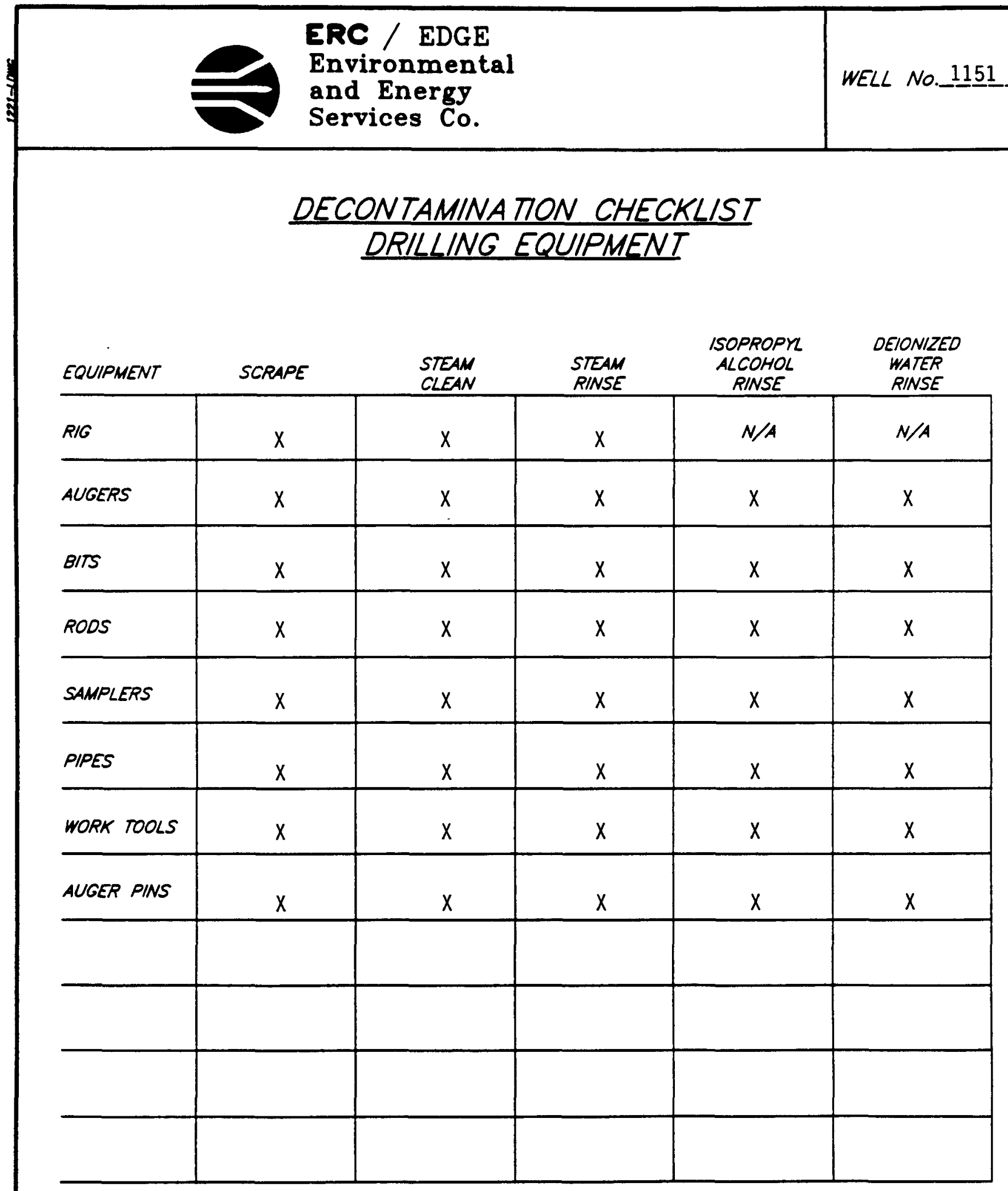

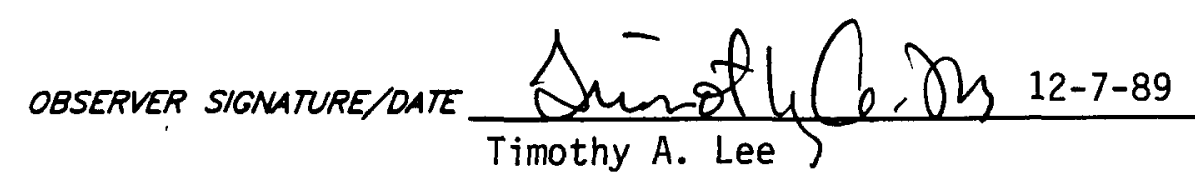




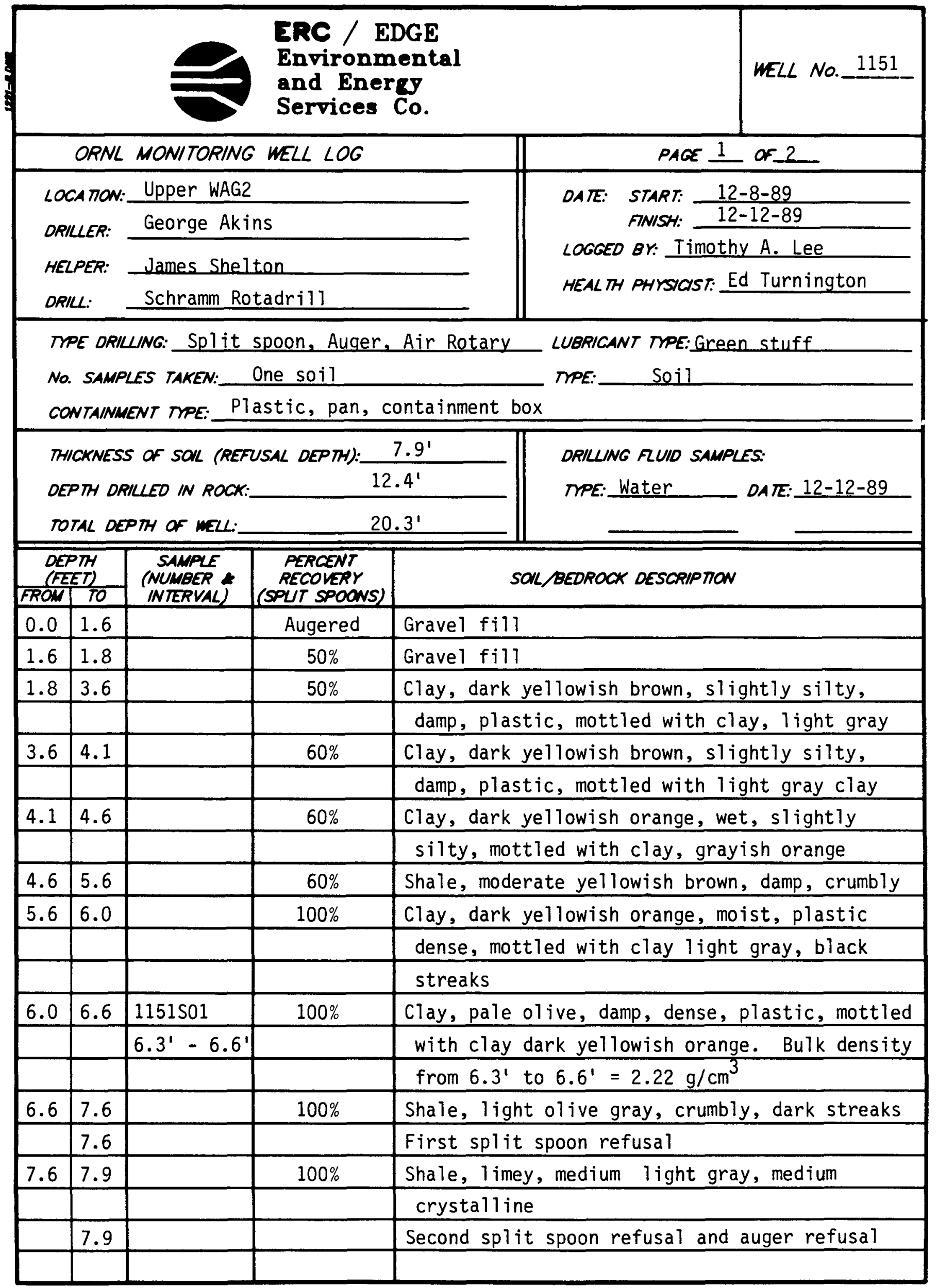




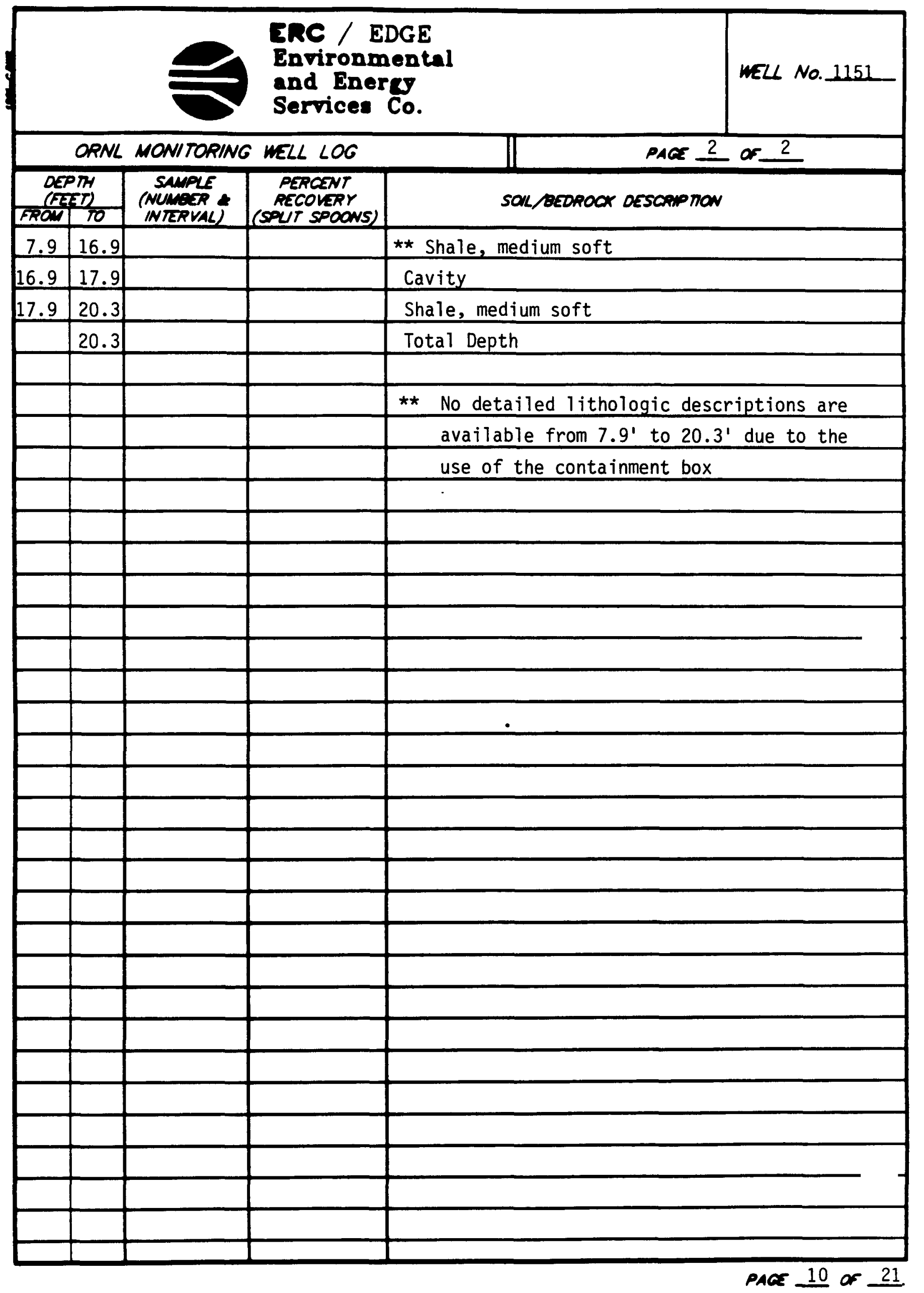




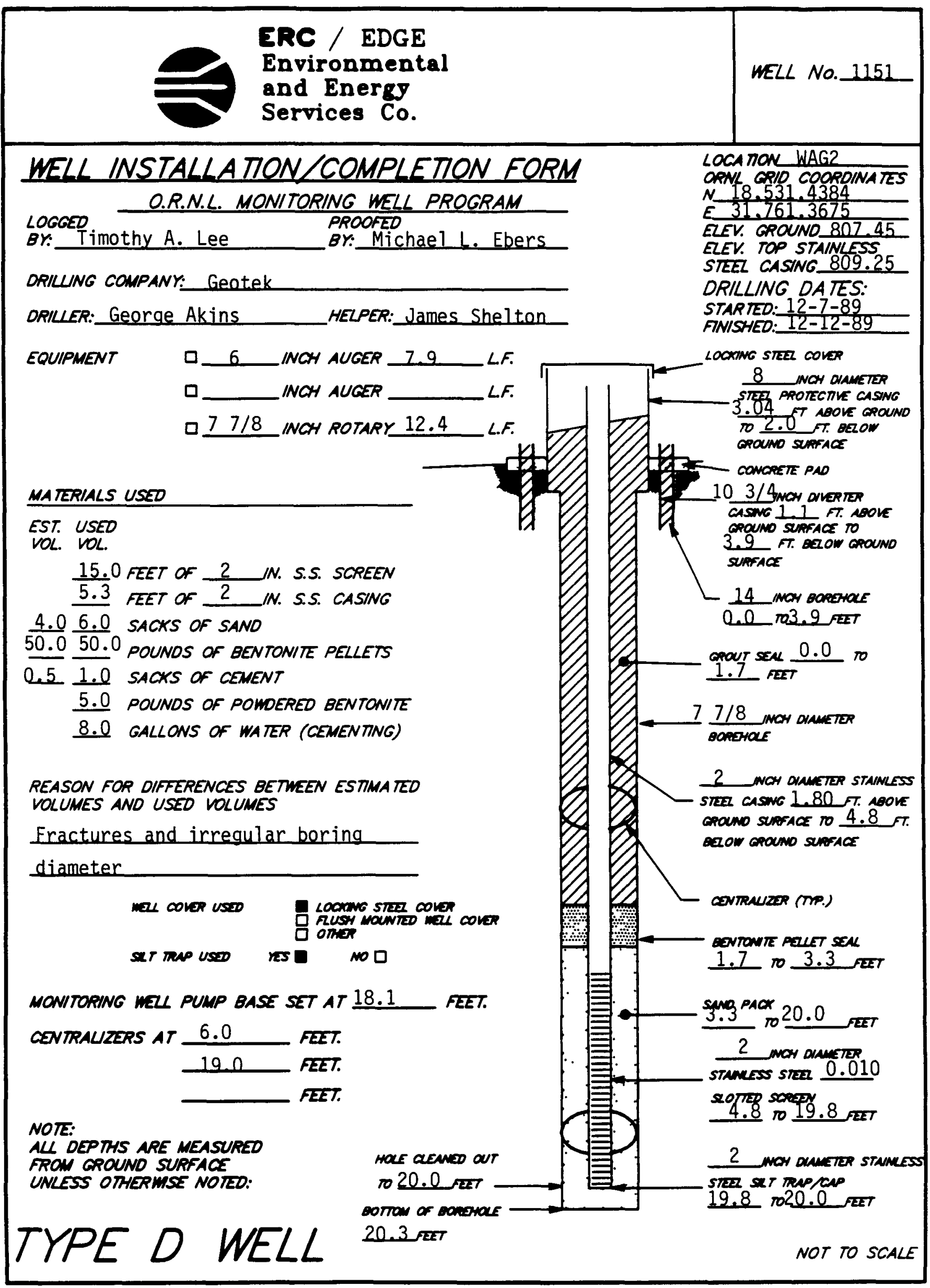

PACE 11 of 21. 
ERC / EDGE

Environmental

WELL NO. 1151

and Energy

Services Co.

DATE: $12-12-89$

\section{MONITORING WELL MATERIALS \\ CERTFICATION}

ITEM/MA TERIAL

DAIE USED BATCH NUMBER

SAND

COMMENTS:

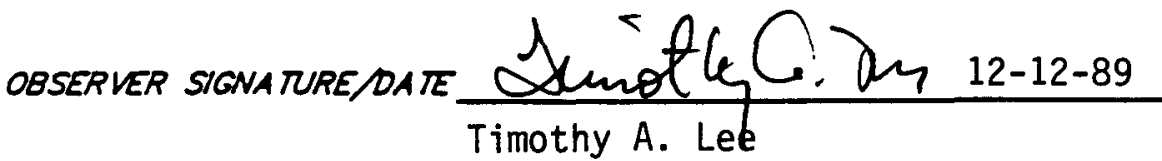

PAGE 12 of 21. 


\begin{tabular}{|l|l|}
\hline $\begin{array}{l}\text { ERC / EDGE } \\
\text { Environmental } \\
\text { and Energo } \\
\text { Services Co. }\end{array}$ & WELL No.1151 \\
\hline & $\frac{\text { POST-WELL COMPLETION }}{\text { CHECKLIST }}$ \\
\hline
\end{tabular}

\section{ROST-MELL COMPLETON TASKS}

1. WUD SCRAPED FROW AUGERS SAMPLERS ANO ALL OTHER EQUIPMENT.

\begin{tabular}{|c|c|}
\hline OA COA & $\begin{array}{l}\text { ANCE } \\
\text { INITALS }\end{array}$ \\
\hline $12-12-89$ & \\
\hline $12-12-89$ & \\
\hline $06-22-89$ & cl \\
\hline $12-12-89$ & \\
\hline
\end{tabular}

4. DRULNG STE PROPERL Y QEANED UP AFTER

complentor of MJL INSTALATION.

2. ALL MU FROM RNG ANO EQUMPUENT SCRAPWGS NO CUTTINOS OUSPOSED OF IN ACCORDANCE MTH THE secaficinaw PROWOED.

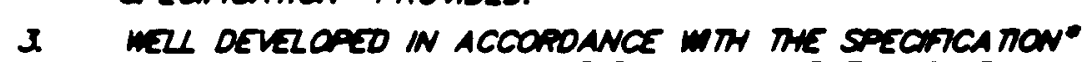
PRO WOEO AND DETAKS OF THE OEVZLOMENT ACTUT RECONOED.

$12-12-89$

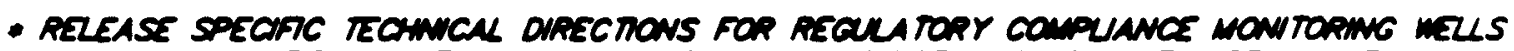

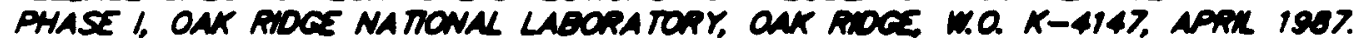

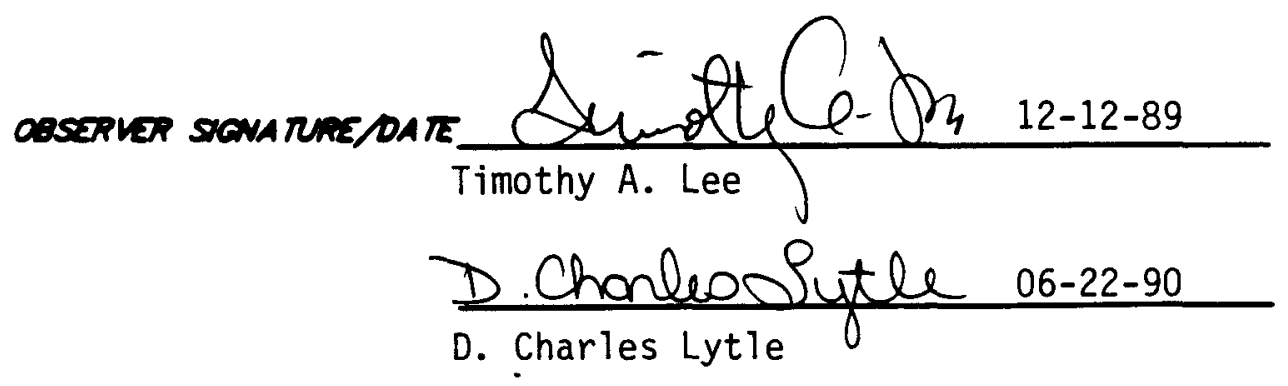




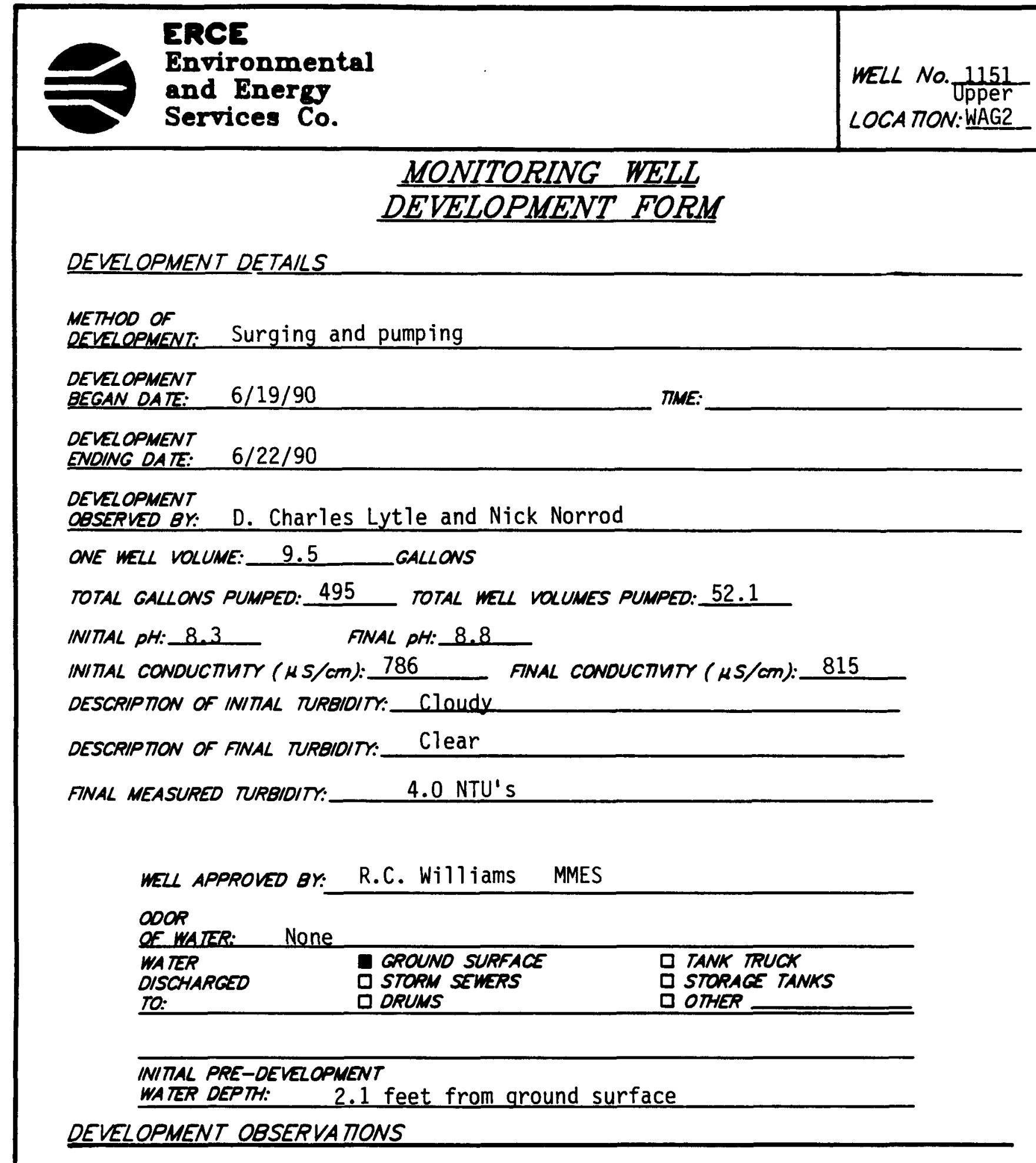




ERCE
Environmental
and EnergJ
Services Co.

COMMENTS Fast recharger and a good producer. Water clean even after surging.

Passed with 4.0 NTU's and 52.1 well volumes. Moved to another hole. 


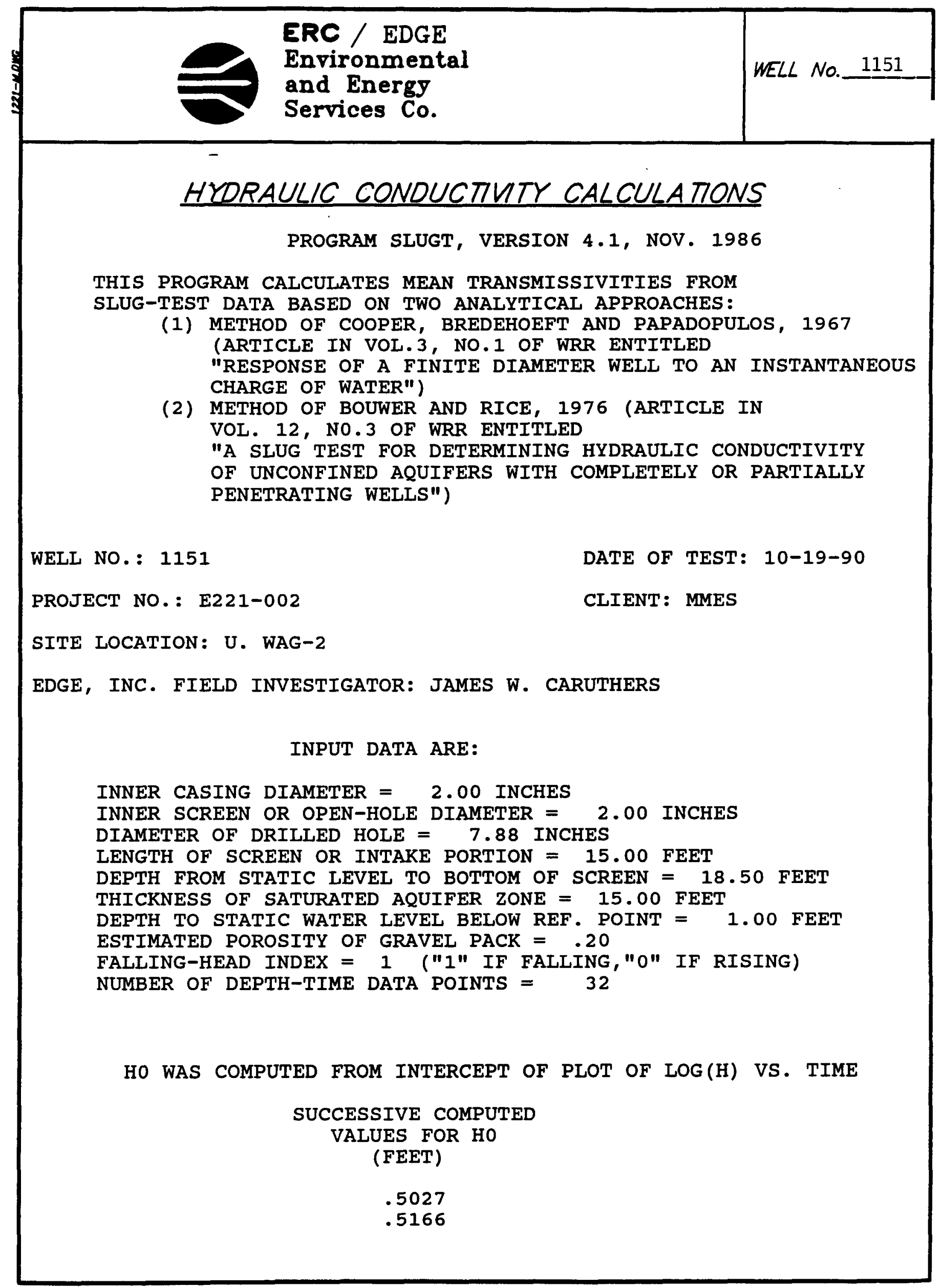




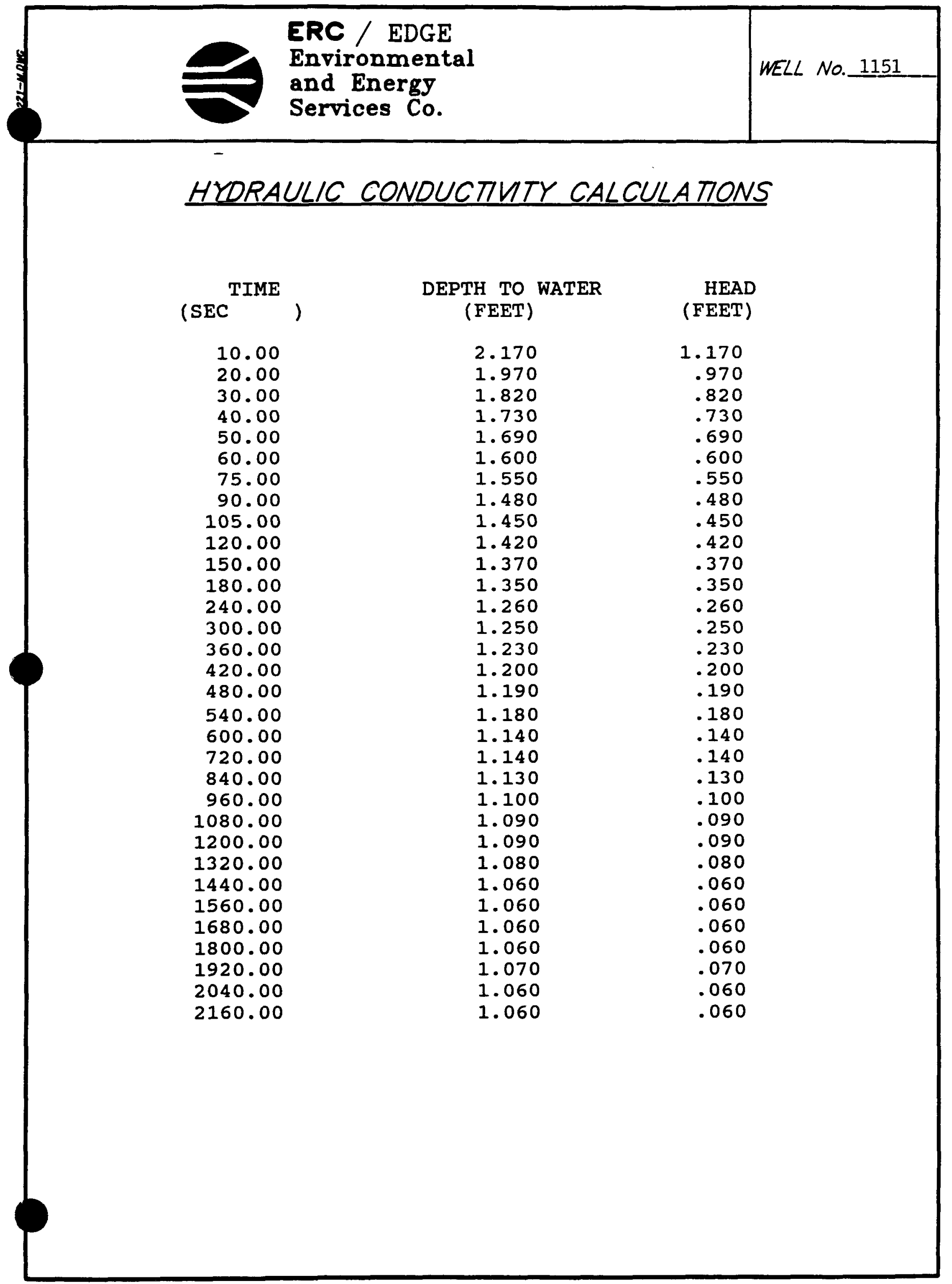




\section{HYDRAULIC CONDUCTIVTY CALCULATIONS}

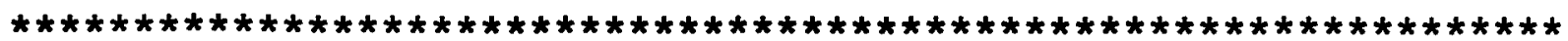

METHOD OF BOUWER AND RICE

COMPUTED RESULTS USING DIAMETER OF DRILLED HOLE:

$$
\text { PERMEABILITY }=9.43 \mathrm{E}-07 \mathrm{FT} / \mathrm{SEC}=2.87 \mathrm{E}-05 \mathrm{CM} / \mathrm{SEC}
$$

TRANSMISSIVITY $=1.41 \mathrm{E}-05 \mathrm{FT} * * 2 / \mathrm{SEC}$

COMPUTED RESULTS USING DIAMETER OF CASING AND SCREEN:

PERMEABILITY $=1.30 \mathrm{E}-06 \mathrm{FT} / \mathrm{SEC}=3.96 \mathrm{E}-05 \mathrm{CM} / \mathrm{SEC}$

TRANSMISSIVITY $=1.95 \mathrm{E}-05 \mathrm{FT} * 2 / \mathrm{SEC}$ 


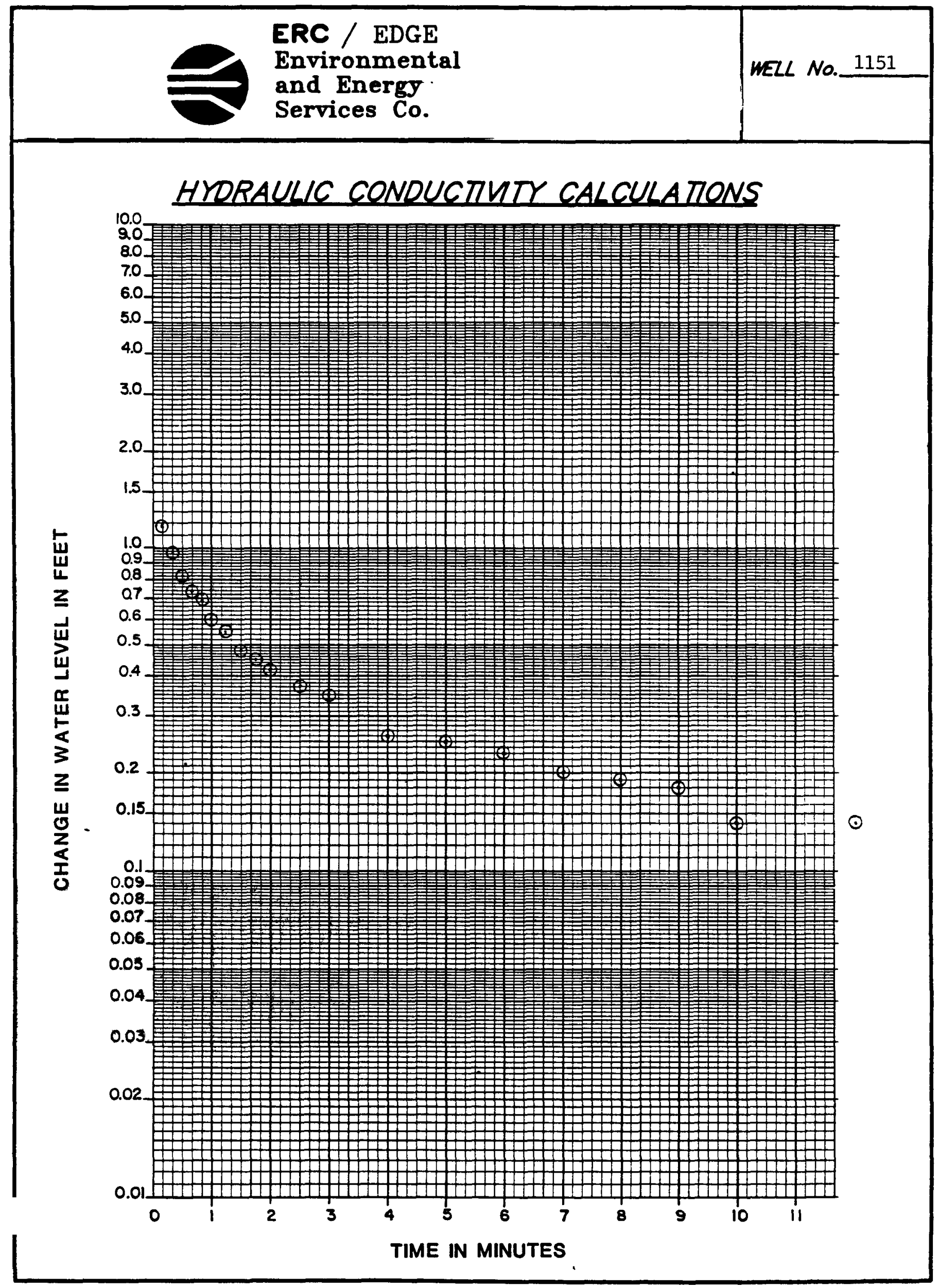

PACE 19 of 21 


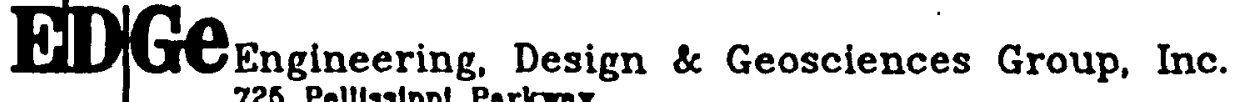
726 Polllsslppl Parkwey

P.0. Box 23010 Koorvillo. in 37933-1010

CHAIN OF CUSTODY RECORD

MARTIN MARIETTA ENERGY SYSTEMS

OAK RIDGE NATIONAL LABORATORY

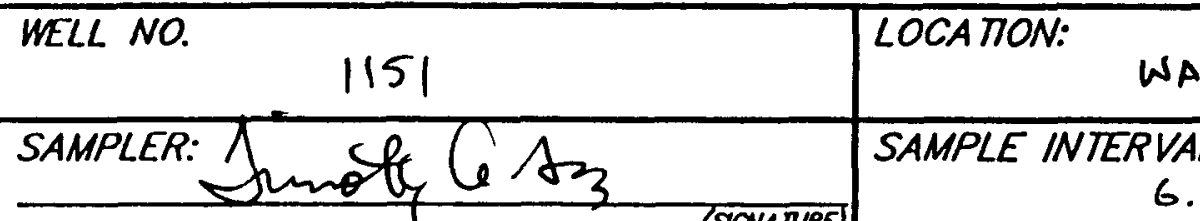

WAG 2

TMPE: SOIL

$6.3^{\prime}-6.6^{\prime}$

\begin{tabular}{l|l}
$\begin{array}{l}\text { DATE: } \\
12-8-89\end{array}$ & TME: \\
\hline
\end{tabular}

RELINQUISHED $B$ Y: (SIGNATURE)

Shmokn Oि tors $D A T E:$

TIME: WTH: $\quad$ RECEIVED BY:
(SIGNATURE)

DATE: $\quad$ TME:

$W T H:$

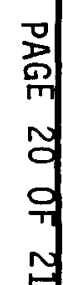

TPE OF SAMPLE:

SPLIT SPOON CORES-SOIL

I AUGER CUTINGS-SOIL

JAS

$12 / 19 / 89 \quad 12: 43$

口 AIR ROTARY CUTINNGS-ROCK

$\square$ DRILL WATER (NO AIR IN SAMPLE) 口OTHER

ALL SAMPLES ARE IMMEDIATELY PLACED IN I-CHEM SPECIALTY CLEANED CONTAINERS AND SEALED. REMARKS: 


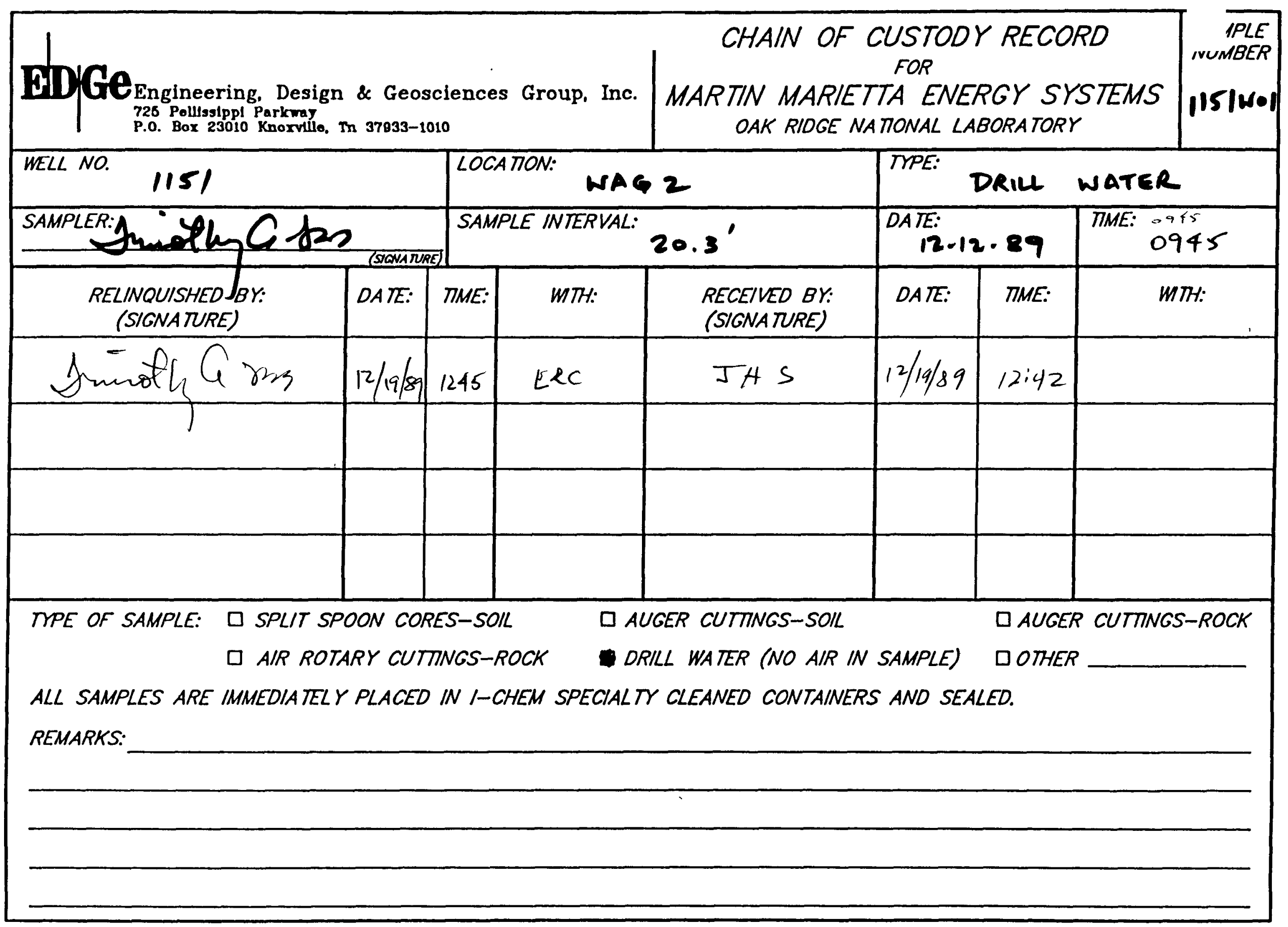


ERC / EDGE

Environmental

and Energy

Services Co.
MONITORING WELL PROGRAM

WEZL DATA NARRATVE

HEZL NO. 1152

\subsection{General Information}

\subsection{Nell Location}

Monitoring well number 1152 is located in Upper WAG 2 . It is on the east side of Upper WAG 2, approximately 500 feet south of building 7900 in HFIR. The location is shown on ORNL drawing number C3E20004A075. Survey coordinates for this well are $N 16,470.8164$, $E$ $32,503.0399(\mathrm{X}-10 \mathrm{grid})$ or latitude $35^{\circ}-54^{\prime}-58.20^{\prime \prime}$ and longitude $84^{\circ}-18^{\prime}-08.51^{\prime \prime}$. Coordinate data were provided by Martin Marietta Energy Systems. The method used for conversion from $\mathrm{X}-10$ grid to Tennessee-Lambert state Plane coordinates came from the publication "Tennessee Valley Authority Data Services Branch and Mapping Services Branch, Oak Ridge, Tennessee, DOE Plant Control, November 6, 1985, Field Book: ESS-3115, pp. 1-20." The latitude and longitude were calculated by Adams craft Herz Walker Engineering, Inc., using methods from the U.S. Coast and Geodetic Survey Publication 62-4, "State Plane Coordinates by Automatic Data Processing."

\subsection{Drilling Information}

Well number 1152 was drilled by Geotek Engineering Company. A Schramm Rotadrill rig was used to drill this boring for monitor well installation under operation of George Akins with the assistance of James Shelton. Drilling commenced on December 11, 1989, and was finished on December 13, 1989. Paragraph 2.4.1 includes a detailed discussion of the well installation and a well schematic is included on the well installation/completion form. A synopsis of the drilling activity follows. This 
information was typed directly from field notes and was edited only when necessary for clarification.

12-08-89 The rig was mobilized to the staked location and set up on plastic sheeting.

12-11-89 Split Spoon samples were taken from surface to 9.9 feet. The boring was widened with a 14 1/2-inch auger to 4.2 feet. Set 4.2 feet of decontaminated 10 3/4-inch diverter casing and grouted it into place with cement. The rig was moved from location.

12-13-89 The rig was moved to location and set up on plastic. The boring was depended from 4.2 feet to 15.0 feet using a 7 7/8-inch air rotary tricone bit into a contaminant box. Set 2 -inch stainless steel screen and casing with sand pack and bentonite seal.

12-14-89 The casing was grouted into place with 1 sack of cement.

This well was logged by ERC Environmental and Energy Services Co., Inc., hydrogeologist Timothy A. Lee. All well construction materials and supplies were from Martin Marietta Energy systems approved batches. The batch origin of individual items is shown on the included Monitoring Well Materials Certification form. 


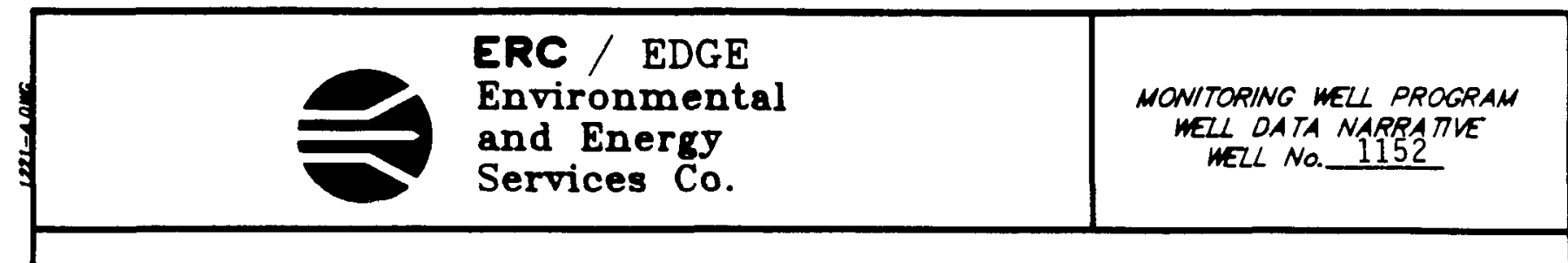

\subsection{Technical Information}

\subsection{Decontamination Procedures}

The drilling rig, down hole tools, surface casing, stainless steel screen, stainless steel casing, centralizers, and stainless steel silt trap underwent the cleaning decontamination procedures outlined in the drilling specifications (Release Specific Technical Directions for Regulatory Compliance Monitoring Wells Phase 1, Oak Ridge National Laboratory, Oak Ridge, w.o. K-4147, April 1987, pgs. 2-4). A checklist of the cleaned materials is included with this data package.

\section{$2.2600109 y$}

The Rome Formation underlies the northern portion of Upper WAG 2 and consists of variegated shale and siltstone with beds of gray, fine grained sandstone. The Conasauga Group underlies the southern portion of Upper WAG 2 and is divided into five members. They are from north to south, the Pumpkin Valley shale, Rutledge Limestone, Rogersville Shale, Maryville Limestone, and Nolichucky shale. These rocks have undergone extensive deformation and contain many folds and faults resulting in varying strike and dips. The regional strike is 56 degrees northeast with dips of about 30 degrees to the southeast. The White Oak creek tear fault is in Upper WAG 2. Displacement varies from 40 feet up to 350 feet. 
ERC / EDGE

Environmental

and Energy

Services Co.
MONITORING WELL PROGRAM

WELL DATA NARRA TVE

\section{3 sample collection}

One soil sample was collected during drilling, placed in an I-CHEM specialty cleaned glass container, sealed and submitted to Sample Receiving, Analytical Chemistry Division, Bldg. 4500S, ORNL. Soil sample 1152501 was collected in the split spoon interval from 6.3 feet to 6.7 feet on December $11,1989$.

A drill water sample was collected from the water pump on the drill rig on December 13, 1989. Analytical results for the samples described above can be obtained from the Remedial Action Program data base at ORNL. The chain of custody forms for these samples are included with this data package.

A bulk density soil sample was collected from the split spoon sample interval from 6.7 feet to 7.0 feet. The sample was measured and weighed, and a bulk density of 2.47 grams $/ \mathrm{cm}^{3}$ was calculated.

The Schramm Rotadrill compressed air was sampled with a cloth filter inserted between drill rods on December 13, 1989. The sample was examined with an ultraviolet light for the presence of hydrocarbons. The filter showed no detectable signs of hydrocarbons.

\subsection{Installation and Development}

\subsubsection{Installation}

This was a Type D well. A 6-inch diameter boring was split spooned and augered from ground surface to auger 
refusal (9.9 feet). The air rotary method was required to complete the boring to the specified total well depth. Therefore, a 14.5- inch diameter boring was augered from ground surface to 4.2 feet and a 10 3/4-inch diverter casing was installed and grouted. An 8-inch diameter boring was then drilled with an air rotary tricone roller bit from 9.9 to 15.0 feet. A 2-inch diameter stainless steel screen with threaded bottom cap was installed from 4.7 to 14.9 feet. A 2-inch diameter stainless steel casing was installed above the screen at 4.7 feet and extended 1.80 feet above ground surface. A sandpack was then tremied into the annular space from 2.9 to 14.9 feet, with a 1.5-foot bentonite pellet seal poured into the annular space above the sandpack from 1.4 to 2.9 feet. The annular space from the top of the bentonite seal to the surface was tremie- grouted with a cement/bentonite slurry. A detail of the well is included on the well installation/completion form.

\subsubsection{Well Development}

Well number 1152 was developed to remove drill cuttings, silt, and other fines. The monitoring was developed using a Geoguard pump with an air compressor. All pumps were cleaned prior to use according to specified cleaning procedures (see Paragraph 2.1). The well was developed until a measured total of 161 gallons of water had been evacuated and the clarity of the discharge water was approved by the company representative. The final turbidity value measured at completion was $4.0 \mathrm{NTU}$ 's. A development form showing the exact method of development and other pertinent data is appended. 
ERC / EDGE

Environmental

and Energy

Services Co.
MONITORING WELL PROGRAM

WEZL OATA NARRATVE MELL NO. 1152

2.4 .3

Installation of Dedicated Monitoring Nell Pump

After the well was developed, a Geoguard Model No. 5614 dedicated monitoring well pump was installed on June 22, 1990, at a depth of 13.4 feet below ground surface. These pumps are decontaminated at American Sigma and are sent prepackaged. A copy of the pump certification is kept on file at ORNL.

\subsection{Hydraulic Conductivity Testing}

Well number 1152 was tested for the determination of hydraulic conductivity of the aquifer in the vicinity of the well screen. This was accomplished by instantaneously adding a known quantity of water to the monitoring well and measuring the recovery of the water level over time. The changing water levels were measured using a Druck 15 psig pressure transducer and an Omnidata Datapod II data recorder. The hydraulic conductivity value of $3.50 \times 10^{-5} \mathrm{~cm} / \mathrm{second}$ (shown as permeability on the hydraulic conductivity calculations printout attached) was calculated using the Bouwer and Rice method. A computer printout of the hydraulic conductivity calculations is included in this data package. 


\section{PRE-DRILLING CHECKLIST FOR MONITORING WELLS}

RRE-DRILLING TASKS

1. EXCAVTION PERMIT OBTAINED

2. ALL EQUIPMENT HAS BEEN CLEANED BEFORE DRILLNG.

30. SCREEN AND CASING HAVE BEEN WASHED, STEAMED, RINSED WTH DE-IONIZED OR DISTLLED WATER, RINSED WTH ISOPROPV ALCOHOL, WRAPPED WTH PROTECTVE COVERING AND STORED OFF THE GROUND.

36. PRE-PACKAGED SCREENS, CASING AND CENTRALIZERS WERE USED.

4. WORK AREA FOR SAMPLE EXAMINATION COVERED WTH CLEAN POL TETHRENE.

5. CLEAN KNIVES, GLVES, SAMPLE JARS AND LABELS ON HAND.

6. POL YETHRENE COVER IN PLACE OVER HOLE.

7. AIR ROTARY COMPRESSED AIR SAMPLED.

COMPLIANGE

DAIE

12-11-89

$12-11-89$

$N / A$

$\underline{12-13-89}$

$12-11-89$

$12-11-89$

$12-11-89$

$\underline{12-13-89}$
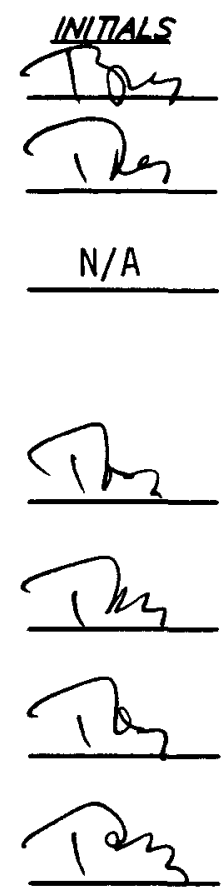

$N / A$

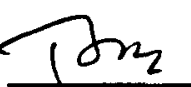

RESUL 75: No hydrocarbons detected under Ultraviolet light

ADDITONAL NOTES/OBSERVATONS:

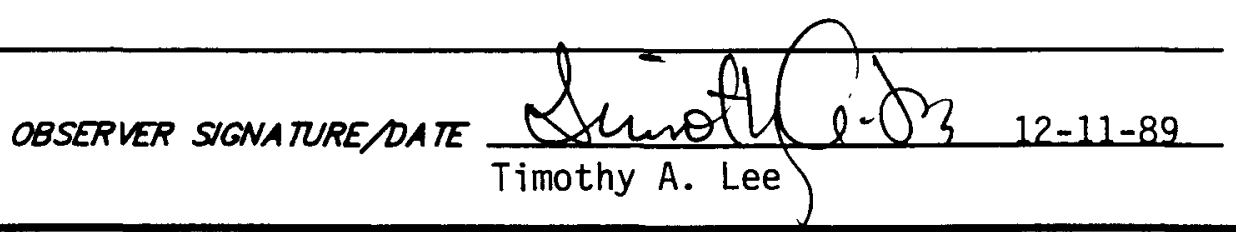

PAGE $\frac{7}{2}$ of 21 . 
ERC / EDGE

Environmental

and Energy

WELL NO. 1152

DECONTAMINATION CHECKLIST

DRILLING EQUIPMENT

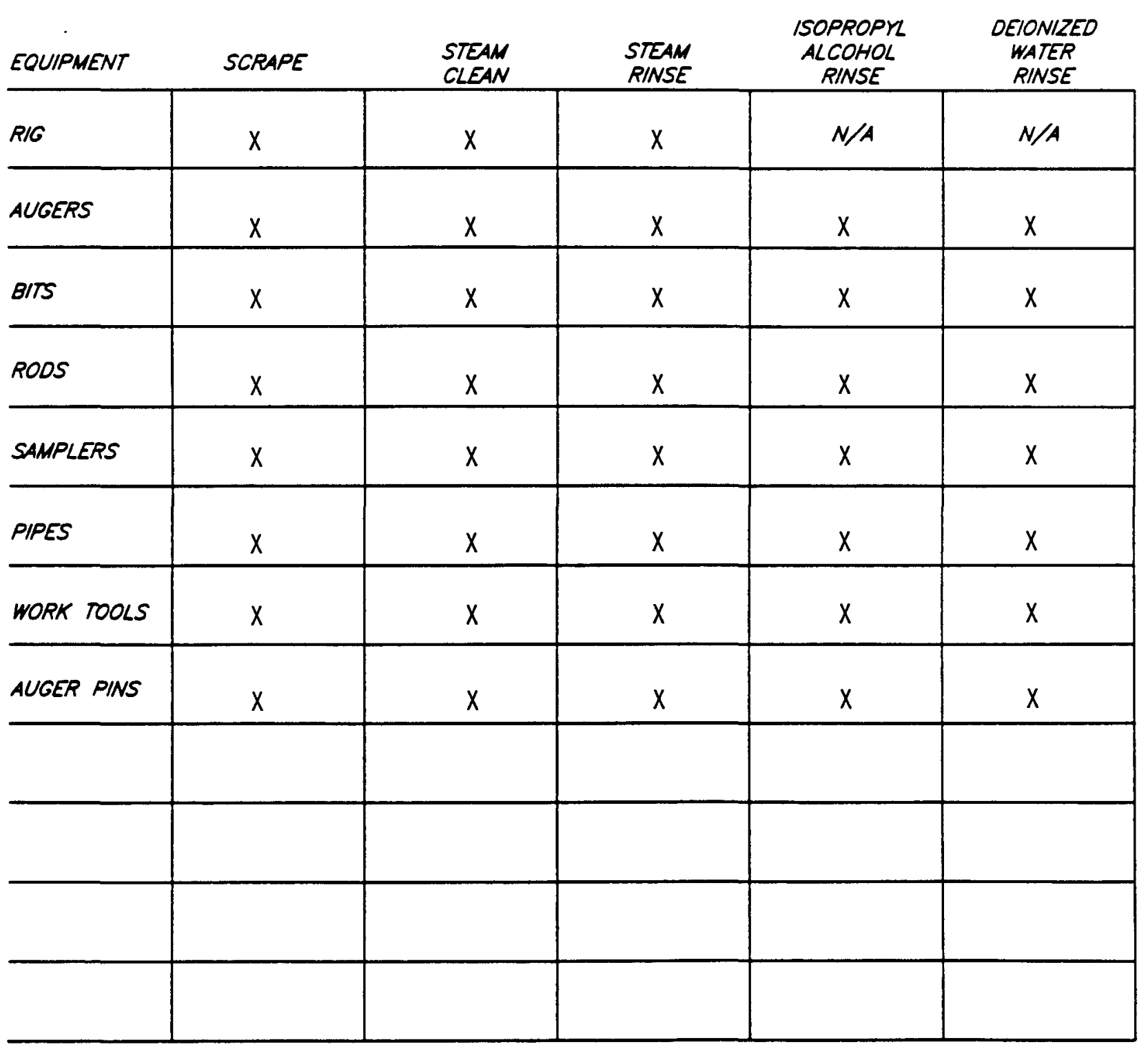

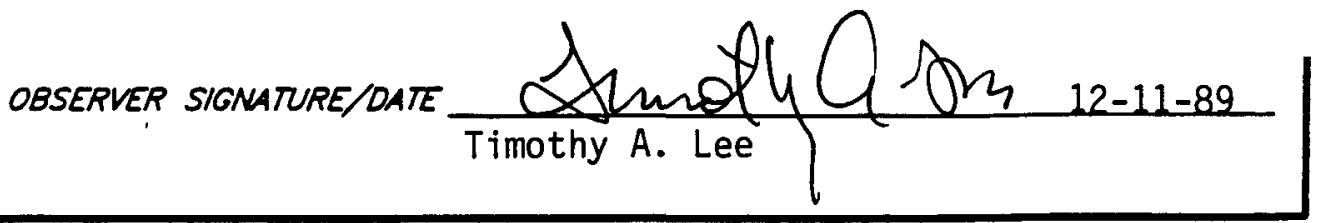




\begin{tabular}{|c|c|c|c|c|}
\hline \multicolumn{5}{|c|}{$\begin{array}{l}\text { ERC / EDGE } \\
\text { Environmental } \\
\text { and Energy } \\
\text { Services Co. }\end{array}$} \\
\hline \multicolumn{4}{|c|}{ ORNL MONITORING WELL LOG } & \multirow{4}{*}{$\begin{array}{l}\text { DATE: START: } \frac{12-11-89}{12-11-89} \\
\text { FNISH: } \frac{\text { Timothy A. Lee }}{\text { LOGGED BY: }} \\
\text { HEAL TH PHYSICST: Bi11 Shinpaugh }\end{array}$} \\
\hline \multirow{3}{*}{\multicolumn{2}{|c|}{$\begin{array}{l}\text { LOCA ION: } \\
\text { ORILLER: } \\
\text { HELPER: } \\
\text { ORILL: }\end{array}$}} & \multicolumn{2}{|l|}{ Upper WAG2 } & \\
\hline & & \multicolumn{2}{|c|}{ James Shelton } & \\
\hline & & \multicolumn{2}{|c|}{ Schramm Rotadri11 } & \\
\hline \multicolumn{5}{|c|}{ TPPE DRILLING: Split spoon, auger, air rotary LUBRICANT TPPE: Green stuff } \\
\hline \multicolumn{4}{|c|}{ No. SAMPLES TAKEN:_One MPE: Soil } & MPE: Soil \\
\hline \multirow{3}{*}{\multicolumn{5}{|c|}{ 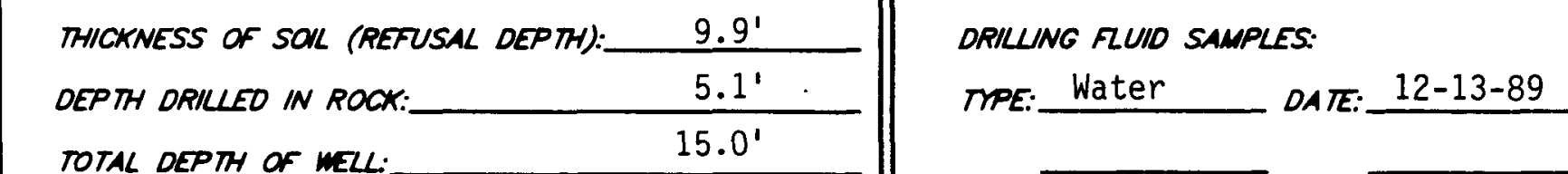 }} \\
\hline & & & & \\
\hline & & & & \\
\hline \multicolumn{2}{|c|}{$\begin{array}{l}\text { DEPTH } \\
\text { (FEET) }\end{array}$} & $\begin{array}{c}\text { SAMPLE } \\
\text { (NUMBER A } \\
\text { INTERVAL) }\end{array}$ & $\begin{array}{c}\text { PERCENT } \\
\text { RECOVERY } \\
\text { (SPUT SPOONS) }\end{array}$ & SOL/BEDROCK DESCRIPTION \\
\hline 0.0 & 2.0 & & Augered & Gravel fill \\
\hline \multirow[t]{2}{*}{2.0} & 4.0 & & $05 \%$ & Clay, dark yellowish brown, wet, loose, very \\
\hline & & & & soft, roots \\
\hline 4.0 & 6.0 & & $0 \%$ & Wet \\
\hline \multirow[t]{2}{*}{6.0} & 6.7 & 1152501 & $50 \%$ & Clay, dusky yellow, wet, soft \\
\hline & & $6.3^{\prime}-6.5^{\prime}$ & & \\
\hline \multirow[t]{3}{*}{6.7} & 7.0 & & $50 \%$ & Clay, light olive brown, damp, medium stiff, \\
\hline & & & & plastic. Bulk density taken from $6.7^{\prime}$ to $7.0^{\prime}$ \\
\hline & & & & is $2.47 \mathrm{~g} / \mathrm{cm}^{3}$ \\
\hline \multirow[t]{3}{*}{7.0} & 7.8 & & $50 \%$ & Shale, yellowish gray to light brown, iron \\
\hline & & & & stains, dry, crumbly \\
\hline & 7.8 & & & First split spoon refusal \\
\hline \multirow[t]{3}{*}{7.8} & 8.7 & & $100 \%$ & Shale, yellowish gray to light brown, iron \\
\hline & & & & stains, crumbly \\
\hline & 8.7 & & & Second split spoon refusal \\
\hline \multirow[t]{2}{*}{8.7} & 9.9 & & Augered & Shale, hard \\
\hline & 9.9 & & & Auger refusal \\
\hline 9.9 & 10.6 & & & $\star \star \star$ Limestone, hard \\
\hline 10.6 & 11.0 & & & Limestone, hard \\
\hline 11.0 & 12.0 & & & Cavity?, soft \\
\hline 12.0 & 15.0 & & & Limestone, hard \\
\hline
\end{tabular}




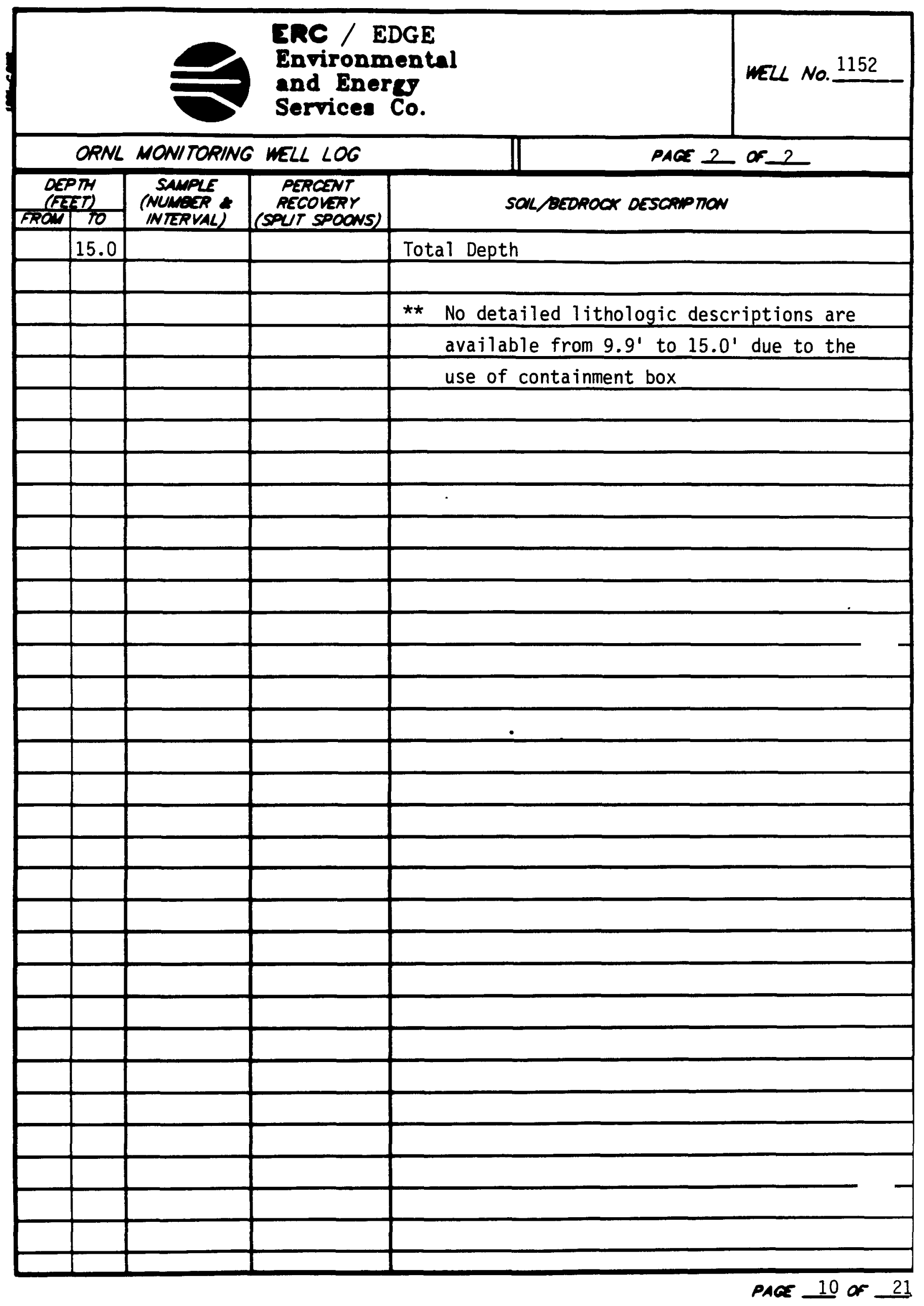




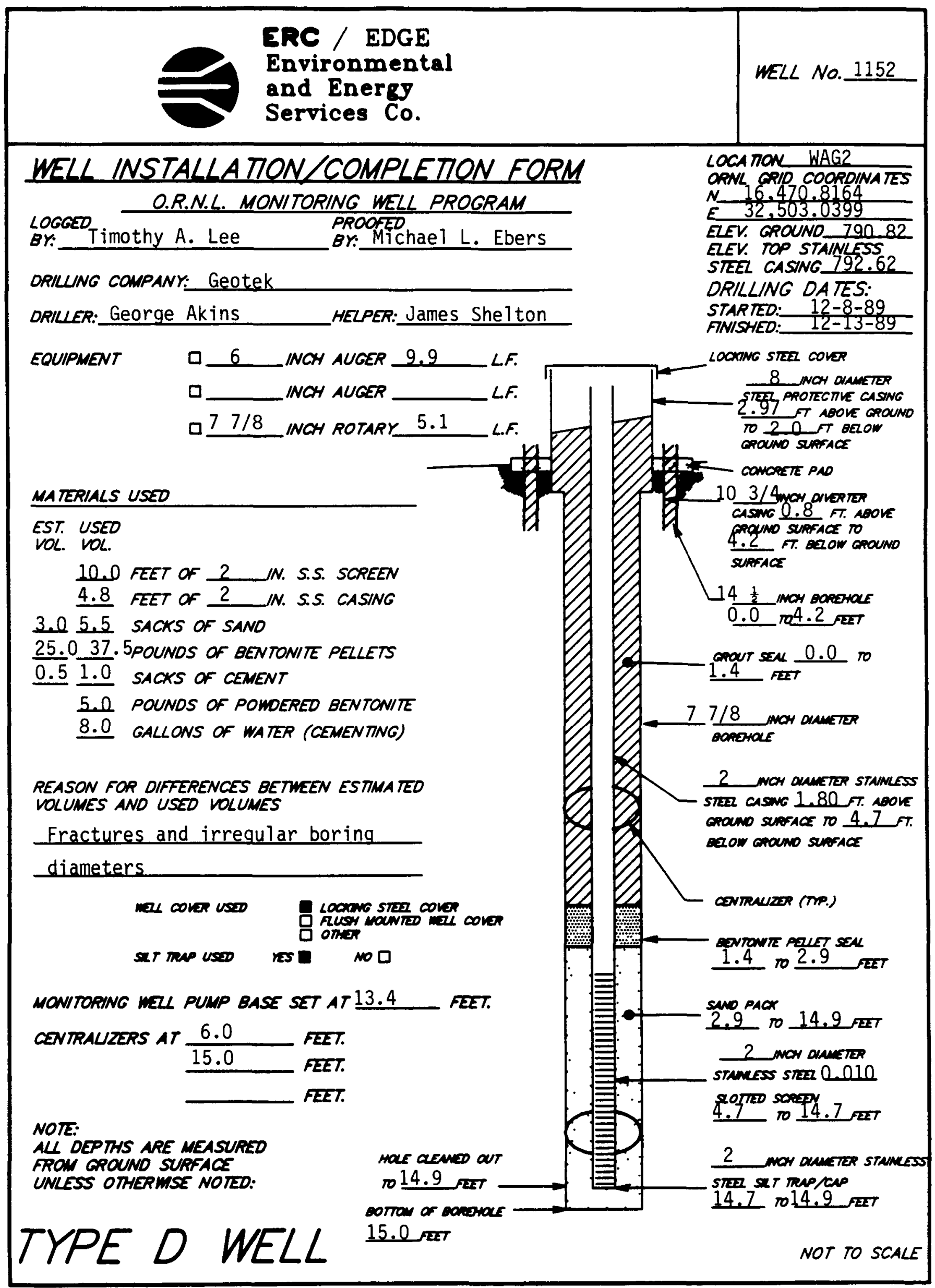




\section{MONITORING WELL MATERIALS CERTIFICA TION}

ITEM/MA TERIAL

SAND

BENTONIE

STAINLESS STEEL SCREEN

STAINLESS STEEL CASING

STAINLESS STEEL CENTRALIZERS

STAINLESS STEEL CAPS

MONITORING WELL PUMP

GROUT

WELL COVERS

SURFACE CASING

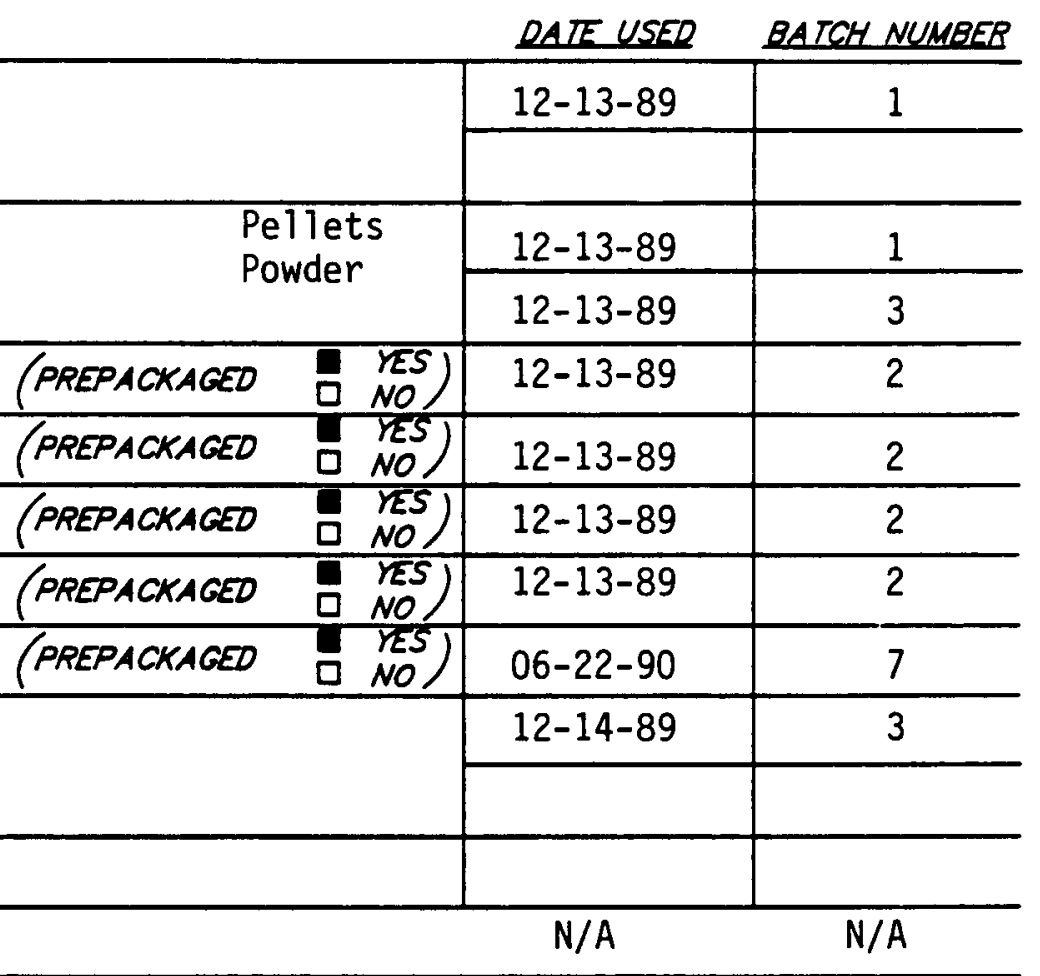

COMMENTS:

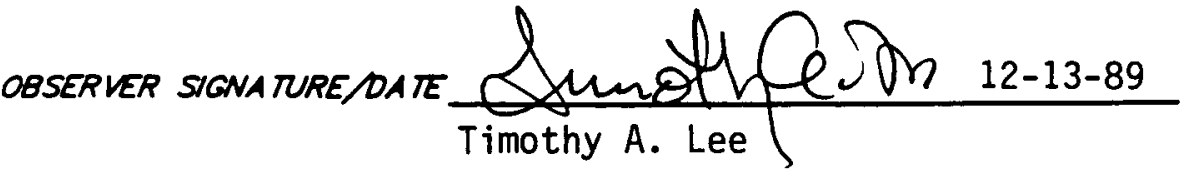

PAGE 12 OF 21. 
ERC / EDGE

Environmental

and Enercy

WELL NO. 1152

Services Co.

\section{POST-WELL COMPLETION CHECKLIST}

\section{POST-MELL COMPLETION TASKS}

1. MU SCRAPED FROM ALGERS SMMPLERS ANO ALL OTHER EOUIPWENT.

COMPIIANCE

QATE INITALS

2. ALL WUD FRON RTE ANO EQUWPMENT SCAAPWCS NO CUTINVS DISPOSED OF IN ACCOPOANCE WIT THE SPECARCA IION PAOWOED.

3 mZL OEVEZOPD IN ACCOROANCE WIH THE SPECATCA nON PROMOED ANO DETAKS OF THE DERELOAUNT ACIUTH RECOADED.

4 DAKLNG STE PROPERL Y QEANED UP AFTER comeletion of MUL INSTALUATON.

\begin{tabular}{l} 
COMPIANCE \\
$\frac{12-11-89}{\text { INITALS }}$ \\
$\frac{12-11-89}{12-22-90}$ DCL \\
\hline DAn
\end{tabular}

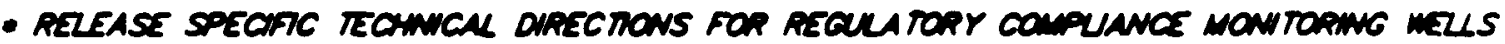

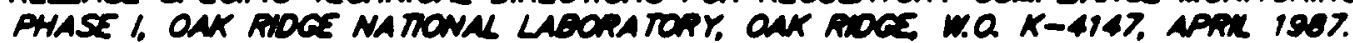

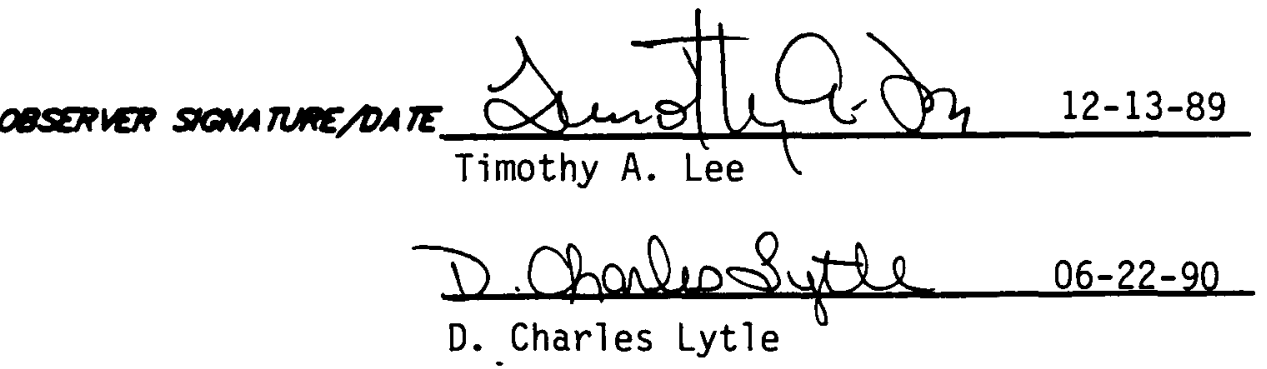




\section{ERes}

Environmental

and Enerey

Services Co.

\section{MONITORING WELL \\ DEVELOPMENT FORM}

DEVELOPMENT DETAILS

METHOO OF

DEVELOEMENT: Surging and pumping

DEVELOPMENT

BEGAN OATE:

$6 / 19 / 90$

TNE:

DEVELOPMENT

ENDING DATE:

$6 / 22 / 90$

OEVELOPMENT

OBSERVED BY: D. Charles Lytle and Nick Norrod

ONE WEL VOLUME: 6.6 GALLONS

TOTAL GALLONS PUMPED: 161

TOTAL WELL VOLUMES PUMPED: 24.4

INITAL PH:_ 8.0

FNAL PH: 8.5

INITAL CONOUCTUTY (N S/cm): 712

OESCRIPTION OF INITAL TURBIOITY:CloudV

DESCRIPTION OF FNAL RURBIOITY: Clear

FNAL MEASURED TURBIDITY:

4.0 NTU'S $^{\prime}$

WEL APPROVED BY: R.C. Williams MMES OOOR None

\begin{tabular}{lll} 
WATER & OROUNO SURFACE & Q TANK TRUCK \\
OISCHARGED & STORN SEWERS & G STORAGE TANKS \\
TO: & D DRUNS & O OTHER \\
\hline
\end{tabular}

INITAL PRE-DEVZOPMENT

WATER DEP TH: 5.8 feet from ground surface

OEVELOPMENT OBSERVA TIONS

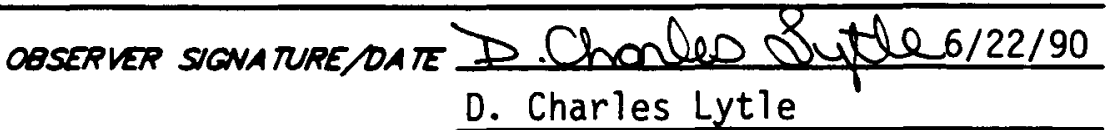




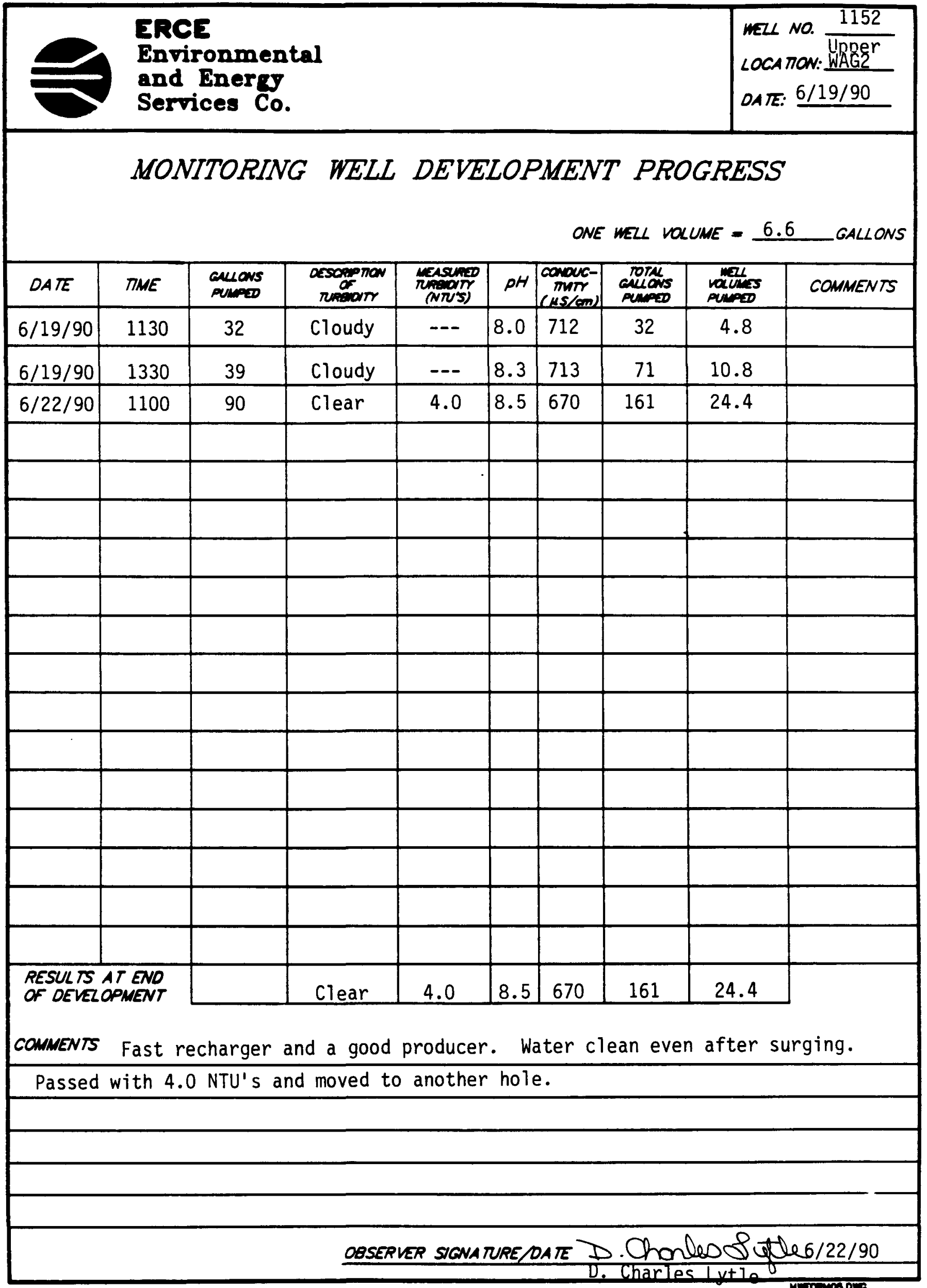




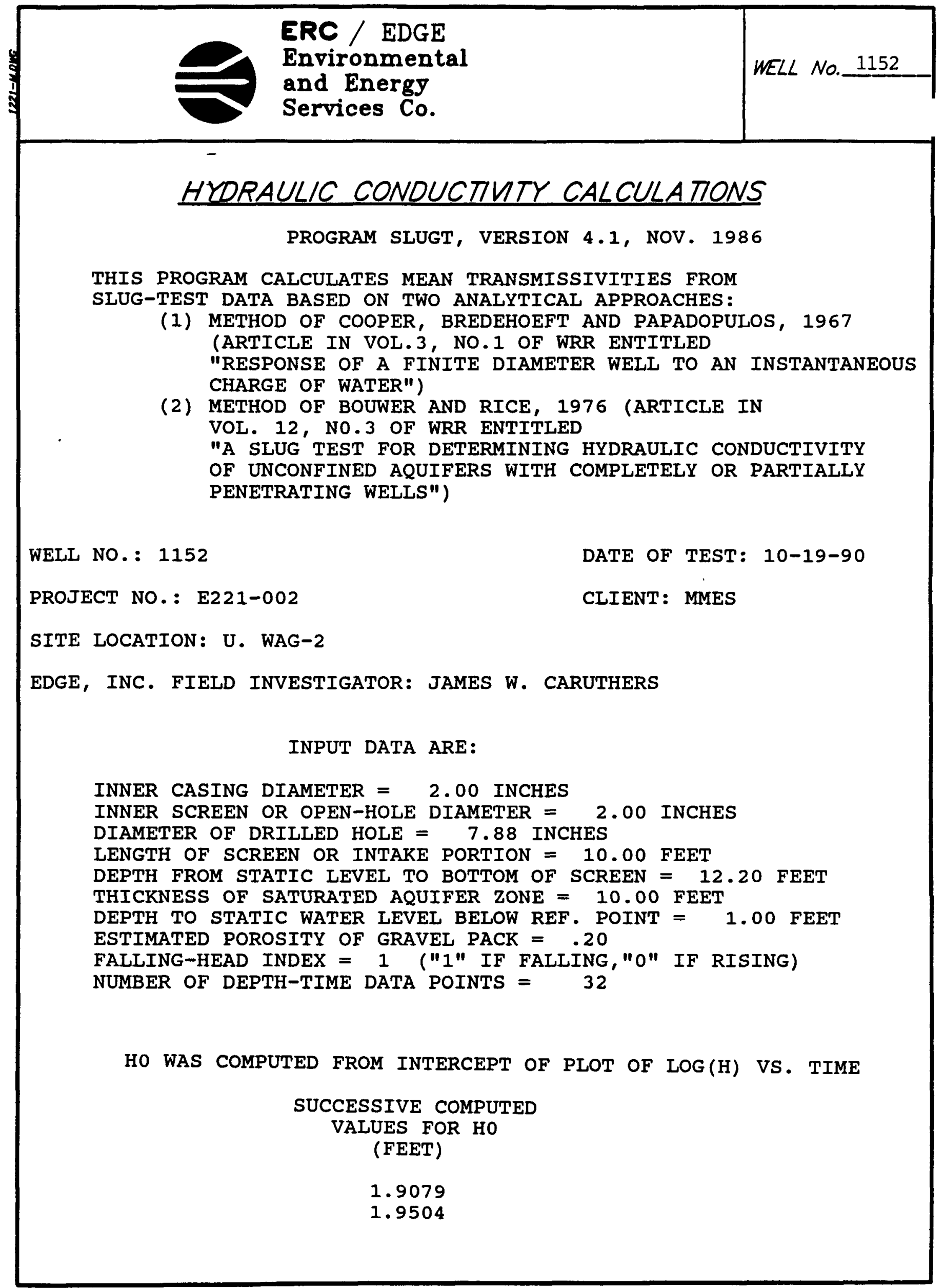

PAGE 16 OF 21 . 


\section{HYDRAULIC CONDUCTIVTY CALCULATIONS}

\begin{tabular}{|c|c|c|}
\hline$\left(\operatorname{SEC}^{\text {TIME }}\right)$ & $\begin{array}{l}\text { DEPTH TO WATER } \\
\text { (FEET) }\end{array}$ & $\begin{array}{l}\text { HEAD } \\
\text { (FEET) }\end{array}$ \\
\hline $\begin{array}{r}10.00 \\
20.00 \\
30.00 \\
40.00 \\
50.00 \\
60.00 \\
75.00 \\
90.00 \\
105.00 \\
120.00 \\
150.00 \\
180.00 \\
240.00 \\
300.00 \\
360.00 \\
420.00 \\
480.00\end{array}$ & $\begin{array}{l}3.920 \\
3.790 \\
3.620 \\
3.480 \\
3.370 \\
3.260 \\
3.120 \\
3.000 \\
2.880 \\
2.780 \\
2.600 \\
2.460 \\
2.240 \\
2.070 \\
1.970 \\
1.870 \\
1.800\end{array}$ & $\begin{array}{r}2.920 \\
2.790 \\
2.620 \\
2.480 \\
2.370 \\
2.260 \\
2.120 \\
2.000 \\
1.880 \\
1.780 \\
1.600 \\
1.460 \\
1.240 \\
1.070 \\
.970 \\
.870 \\
.800\end{array}$ \\
\hline $\begin{array}{r}540.00 \\
600.00 \\
720.00 \\
840.00 \\
960.00 \\
1080.00 \\
1200.00 \\
1320.00 \\
1440.00 \\
1560.00 \\
1680.00 \\
1800.00 \\
1920.00 \\
2040.00 \\
2160.00\end{array}$ & $\begin{array}{l}1.730 \\
1.650 \\
1.570 \\
1.510 \\
1.460 \\
1.420 \\
1.370 \\
1.320 \\
1.310 \\
1.300 \\
1.290 \\
1.260 \\
1.260 \\
1.260 \\
1.250\end{array}$ & $\begin{array}{l}.730 \\
.650 \\
.570 \\
.510 \\
.460 \\
.420 \\
.370 \\
.320 \\
.310 \\
.300 \\
.290 \\
.260 \\
.260 \\
.260 \\
.250\end{array}$ \\
\hline
\end{tabular}




\title{
HYDRAULIC CONDUCTIVTY CALCULATIONS
}

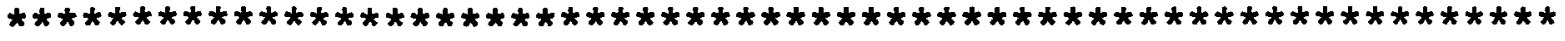 \\ METHOD OF BOUWER AND RICE \\ COMPUTED RESULTS USING DIAMETER OF DRILLED HOLE: \\ PERMEABILITY $=1.15 \mathrm{E}-06 \mathrm{FT} / \mathrm{SEC}=3.50 \mathrm{E}-05 \mathrm{cM} / \mathrm{SEC}$ \\ TRANSMISSIVITY $=1.15 \mathrm{E}-05 \mathrm{FT} * \star 2 / \mathrm{SEC}$
}

COMPUTED RESULTS USING DIAMETER OF CASING AND SCREEN:

PERMEABILITY $=1.64 \mathrm{E}-06 \mathrm{FT} / \mathrm{SEC}=4.99 \mathrm{E}-05 \mathrm{CM} / \mathrm{SEC}$

TRANSMISSIVITY $=1.64 \mathrm{E}-05 \mathrm{FT} * 2 / \mathrm{SEC}$ 


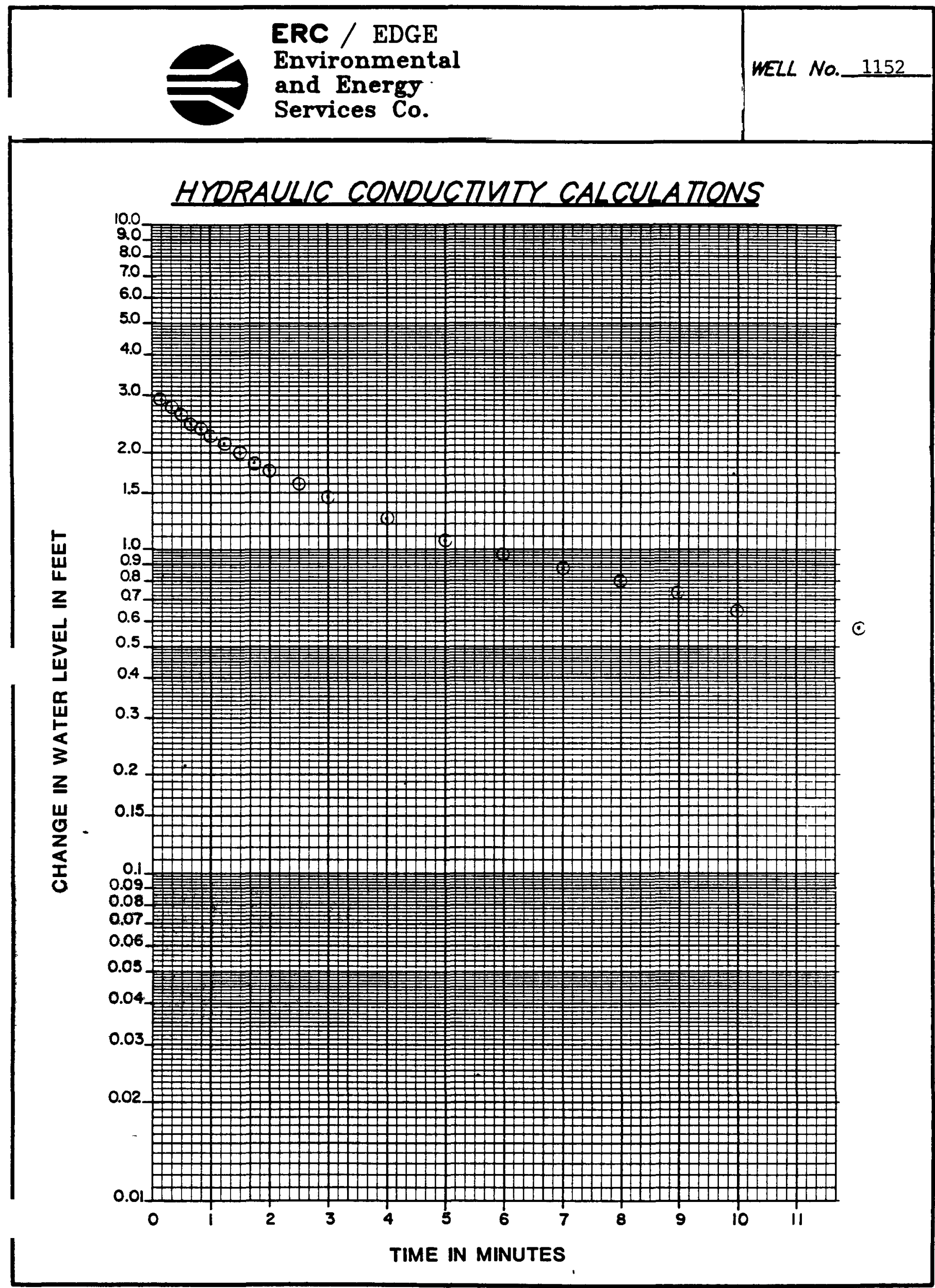

PACE 19 or 21 


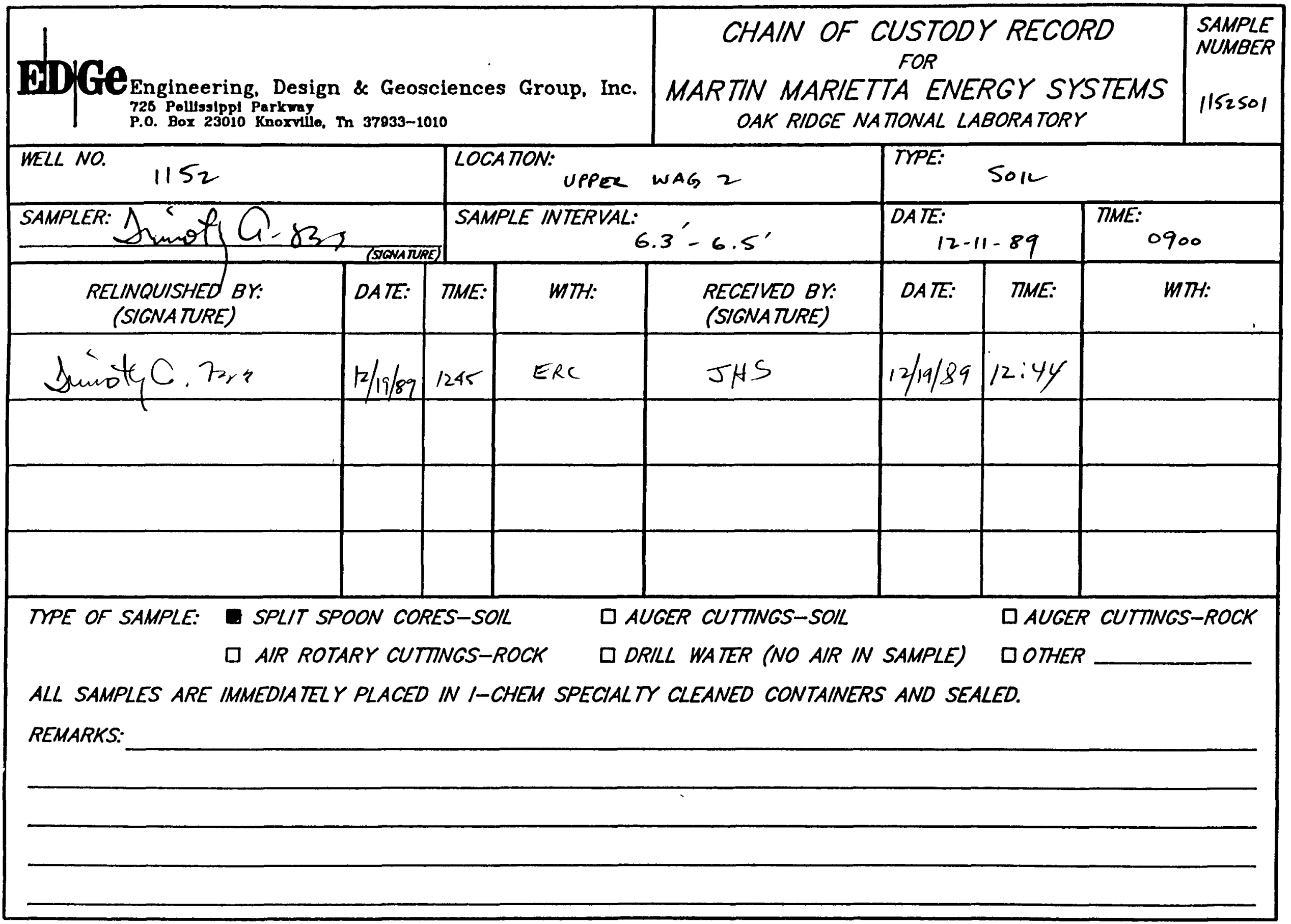


1. A Engineering, Design \& Geosclences Group, Inc. 726 Pollissippl Parkway

P.o. Bor 23010 Knorvillo, In 37933-1010

CHAIN OF CUSTODY RECORD

FOR

MARTIN MARIETTA ENERGY SYSTEMS

OAK RIDGE NATIONAL LABORATORY

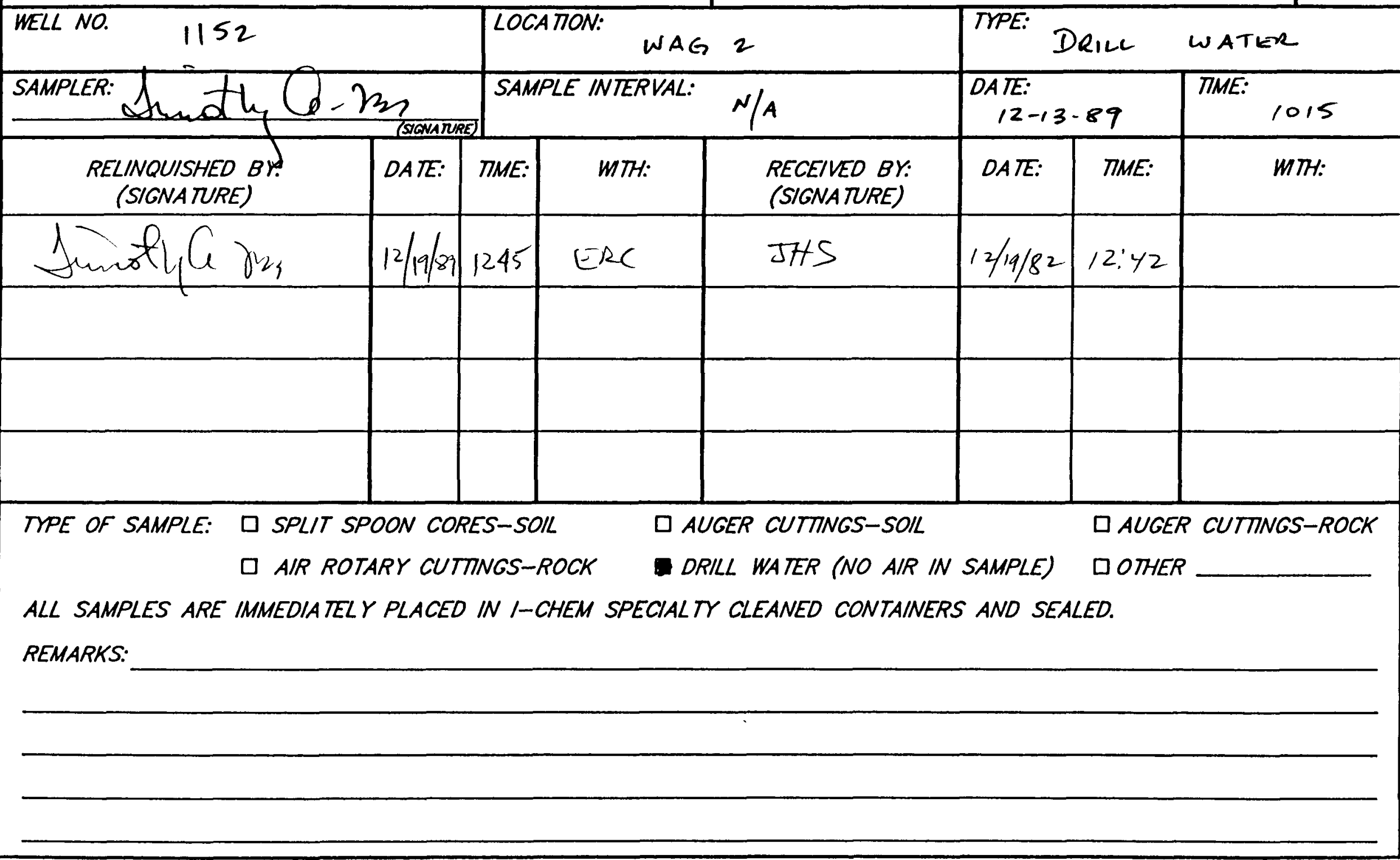




\subsection{General Information}

\subsection{Nell Location}

Monitoring well number 1153 is located in Upper WAG 2 . It is approximately 500 feet due east of building number 7920. The location is shown on ORNL drawing number C3E20004A075. Survey coordinates for this well are $N$ $17,395.6675, \mathrm{E} 33,324.8783$ (X-10 grid) or latitude $35^{\circ}$ $55^{\prime}-10.32^{\prime \prime}$ and longitude $84^{\circ}-18^{\prime}-06.46^{\prime \prime}$. Coordinate data were provided by Martin Marietta Energy systems. The method used for conversion from $x-10$ grid to TennesseeLambert state Plane Coordinates came from the publication "Tennessee Valley Authority Data Services Branch and Mapping Services Branch, Oak Ridge, Tennessee, DOE Plant Control, November 6, 1985, Field Book: ESS-3115, pp. 120." The latitude and longitude were calculated by Adams Craft Herz Walker Engineering, Inc., using methods from the U.S. Coast and Geodetic survey Publication 62-4, "State Plane Coordinates by Automatic Data Processing."

\subsection{Driling Information}

Well number 1153 was drilled by Geotek Engineering Company. A Schramm Rotadrill rig was used to drill this boring for monitor well installation under operation of George Akins with the assistance of James Shelton and Phil Getsi. Drilling commenced on December 14, 1989, and was finished on December 20, 1989. Paragraph 2.4.1 includes a detailed discussion of the well installation and a well schematic is included on the well installation/completion form. A synopsis of the drilling 
ERC / EDGE

Environmental

and Energy

Services Co.
MONITORING WELL PROGRAM

WELL OATA NARPATVE WELL No. 1153

activity follows. This information was typed directly from field notes and was edited only when necessary for clarification.

12-14-89 The rig was mobilized to the staked location and set up on plastic sheeting. Split spoon samples were taken from the surface to refusal at 5.6 feet. The boring was widened with a 14 1/2-inch auger to 4.1 feet and set $103 / 4$-inch decontaminated steel diverter casing. The rig was moved from location.

12-15-89 The diverter casing was grouted into place.

12-20-89 The rig was moved to the location. The boring was deepened to 18.0 feet using a $77 / 8$ air rotary tricone bit into a containment box. Set 2-inch stainless steel casing with sand pack and bentonite seal.

12-21-89 The casing was grouted into place with 2 sacks of cement.

This well was logged by ERC Environmental and Energy Services Co., Inc., hydrogeologist Timothy A. Lee. All well construction materials and supplies were from Martin Marietta Energy Systems approved batches. The batch origin of individual items is shown on the included Monitoring Well Materials Certification form.

2.0 Technical Information

\subsection{Decontamination Procedures}

The drilling rig, down hole tools, surface casing, stainless steel screen, stainless steel casing, 
centralizers, and stainless steel silt trap underwent the cleaning decontamination procedures outlined in the drilling specifications (Release specific Technical Directions for Regulatory Compliance Monitoring Wells Phase 1, Oak Ridge National Laboratory, Oak Ridge, w.0. K-4147, April 1987, pgs. 2-4). A checklist of the cleaned materials is included with this data package.

\subsection{Geology}

The Rome Formation underlies the northern portion of Upper WAG 2 and consists of variegated shale and siltstone with beds of gray, fine grained sandstone. The Conasauga Group underlies the southern portion of Upper WAG 2 and is divided into five members. They are from north to south, the Pumpkin Valley Shale, Rutledge Limestone, Rogersville Shale, Maryville Limestone, and Nolichucky shale. These rocks have undergone extensive deformation and contain many folds and faults resulting in varying strike and dips. The regional strike is 56 degrees northeast with dips of about 30 degrees to the southeast. The White Oak creek tear fault is in Upper WAG 2. Displacement varies from 40 feet up to 350 feet.

\subsection{Bample collection}

One soil sample was collected during drilling, placed in an I-CHEM specialty cleaned glass container, sealed and submitted to Sample Receiving, Analytical Chemistry Division, Bldg. 4500S, ORNL. Soil sample 1153501 was collected in the split spoon interval from 3.3 feet to 3.6 feet on December 14,1989 . A drill water sample was collected from the water pump on the drill rig on 
ERC / EDGE

Environmental

and Energy

Services Co.

December 20, 1989. Analytical results for the soil and water samples described above can be obtained from the Remedial Action Program data base at ORNL. Chain of custody forms for these samples are included with this data package.

A bulk density soil sample was collected from the split spoon sample interval from 1.4 feet to 1.7 feet. The sample was measured and weighed, and a bulk density of 2.14 grams $/ \mathrm{cm}^{3}$ was calculated.

The Schramm Rotadrill compressed air was sampled with a cloth filter inserted between drill rods on December 20, 1989. The sample was examined with an ultraviolet light for the presence of hydrocarbons. The filter showed no evidence of hydrocarbons.

\subsection{Installation and Development}

\section{4 .1 Installation}

This was a Type D well. A 6-inch diameter boring was split spooned and augered from ground surface to auger refusal ( 5.6 feet). The air rotary method was required to complete the boring to the specified total well depth. Therefore, a 14.5- inch diameter boring was augered from ground surface to 4.1 feet and a 10 3/4-inch diverter casing was installed and grouted. An 8-inch diameter boring was then drilled with an air rotary tricone roller bit from 5.6 to 18.0 feet. A 2-inch diameter stainless steel screen with threaded bottom cap was installed from 7.8 to 18.0 feet. A 2-inch diameter stainless steel casing was installed above the, screen at 7.8 feet and 
extended 1.64 feet above ground surface. A sandpack was then tremied into the annular space from 5.8 to 18.0 feet, with a 2.1-foot bentonite pellet seal poured into the annular space above the sandpack from 3.7 to 5.8 feet. The annular space from the top of the bentonite seal to the surface was tremie- grouted with a cement/bentonite slurry. A detail of the well is included on the well installation/completion form.

\subsubsection{Well Development}

Well number 1153 was developed to remove drill cuttings, silt, and other fines. The monitoring well was developed using a Geoguard pump with an air compressor. All pumps were cleaned prior to use according to specified cleaning procedures (see Paragraph 2.1). The well was developed until a measured total of 124 gallons of water had been evacuated and the clarity of the discharge water was approved by the company representative. The final turbidity value measured at completion was $3.0 \mathrm{NTU}$ 's. A development form showing the exact method of development and other pertinent data is appended.

2.4.3 Installation of Dedicated Monitoring Nell Pump

After the well was developed, a Geoguard Model No. 5614 dedicated monitoring well pump was installed on June 26 , 1990, at a depth of 16.7 feet below ground surface. These pumps are decontaminated at American Sigma and are sent prepackaged. A copy of the pump certification is kept on file at ORNL. 


\begin{tabular}{|c|c|}
\hline & $\begin{array}{l}\text { ERC / EDGE } \\
\text { Environmental } \\
\text { and Energy } \\
\text { Services Co. }\end{array}$ \\
\hline 2.5 & $\begin{array}{l}\text { Hydraulic conductivity Testing } \\
\text { Well number } 1153 \text { was tested for the determination of } \\
\text { hydraulic conductivity of the aquifer in the vicinity of } \\
\text { the well screen. This was accomplished by } \\
\text { instantaneously adding a known quantity of water to the } \\
\text { monitoring well and measuring the recovery of the water } \\
\text { level over time. The changing water levels were measured } \\
\text { using a Druck } 15 \text { psig pressure transducer and an } \\
\text { Omidata Datapod II data recorder. The hydraulic } \\
\text { conductivity value of } 5.27 \times 10^{-5} \text { cm/second (shown as } \\
\text { permeability on the hydraulic conductivity calculations } \\
\text { printout attached) was calculated using the Bouwer and } \\
\text { Rice method. A computer printout of the hydraulic } \\
\text { conductivity calculations is included in this data } \\
\text { package. }\end{array}$ \\
\hline
\end{tabular}




\section{PRE-DRILLING CHECKLIST FOR MONITORING WELLS}

\section{RRE-DRIUUNG TASKS}

1. EXCAVTION PERMIT OBTAINED

2. ALL EQUIPMENT HAS BEEN CLEANED BEFORE ORILLING.

30. SCREEN AND CASING HAVE BEEN WASHED, STEAMED, RINSED WTH DE-IONIZED OR DISTLLED WATER, RINSED WTH ISOPROPV ALCOHOL, WRAPPED WTH PROTECTVE COVERING AND STORED OFF THE GROUND.

36. PRE-PACKAGED SCREENS, CASING AND CENTRALIZERS WERE USED.

4. WORK AREA FOR SAMPLE EXAMINATION COVERED WTH CLEAN POL KETHRENE.

5. CLEAN KNIVES, GLOVES, SAMPLE JARS AND LABELS ON HANO.

6. POLYETHRENE COVER IN PLACE OVER HOLE.

7. AIR ROTARY COMPRESSED AIR SAMPLED.
COMPLANCE

$$
\text { DAIE }
$$$$
\text { 12-14-89 }
$$

MURALS

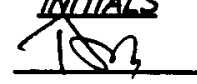

12-14-89

Th

$N / A$

$N / A$

12-20-89

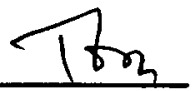

12-14-89

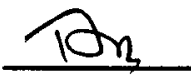

12-14-89

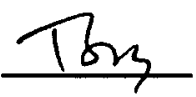

12-14-89

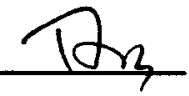

12-20-89

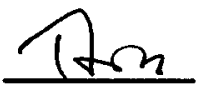

RESULIS: No detectable signs of hydrocarbons under ultraviolet light

ADOITONAL NOTES/OBSERVATONS:

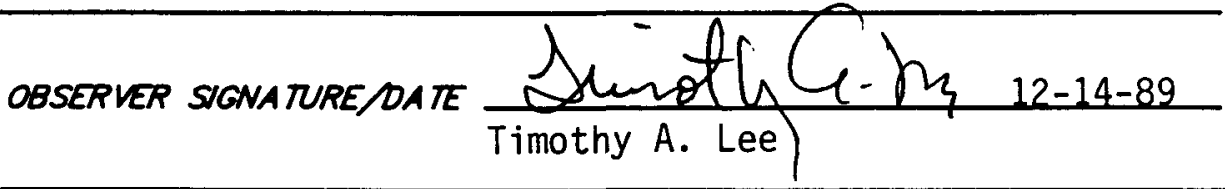


ERC / EDGE

Environmental

and Energy

Services Co.

\section{DECONTAMINATION CHECKLIST \\ DRILLING EQUIPMENT}

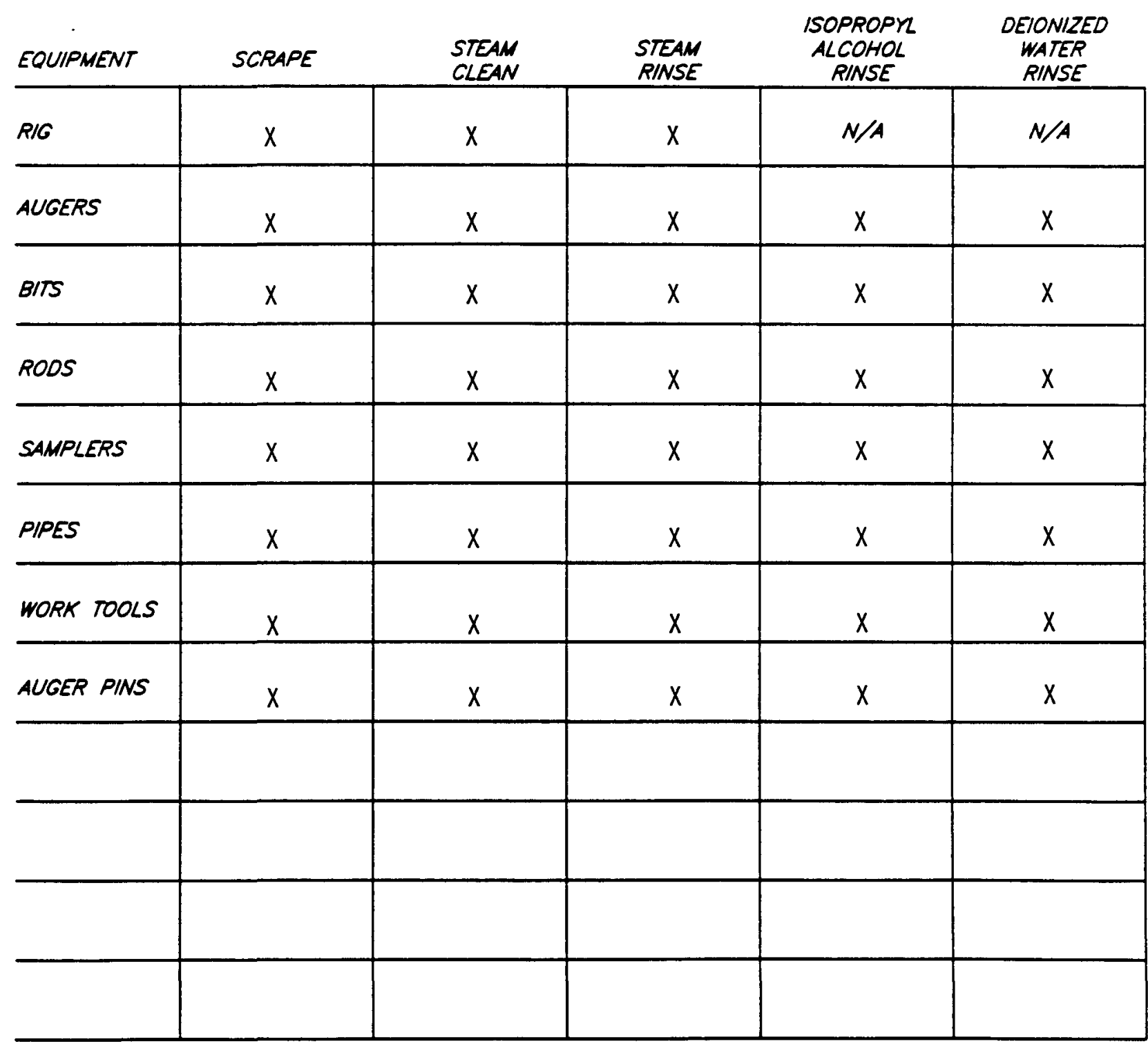

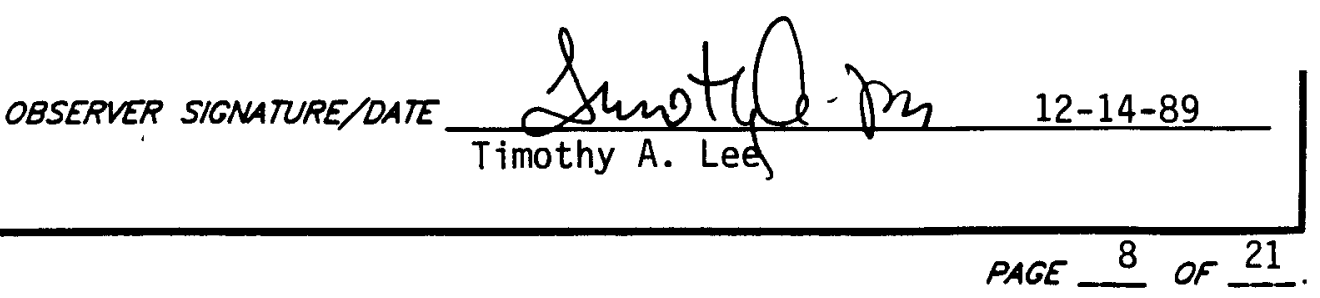




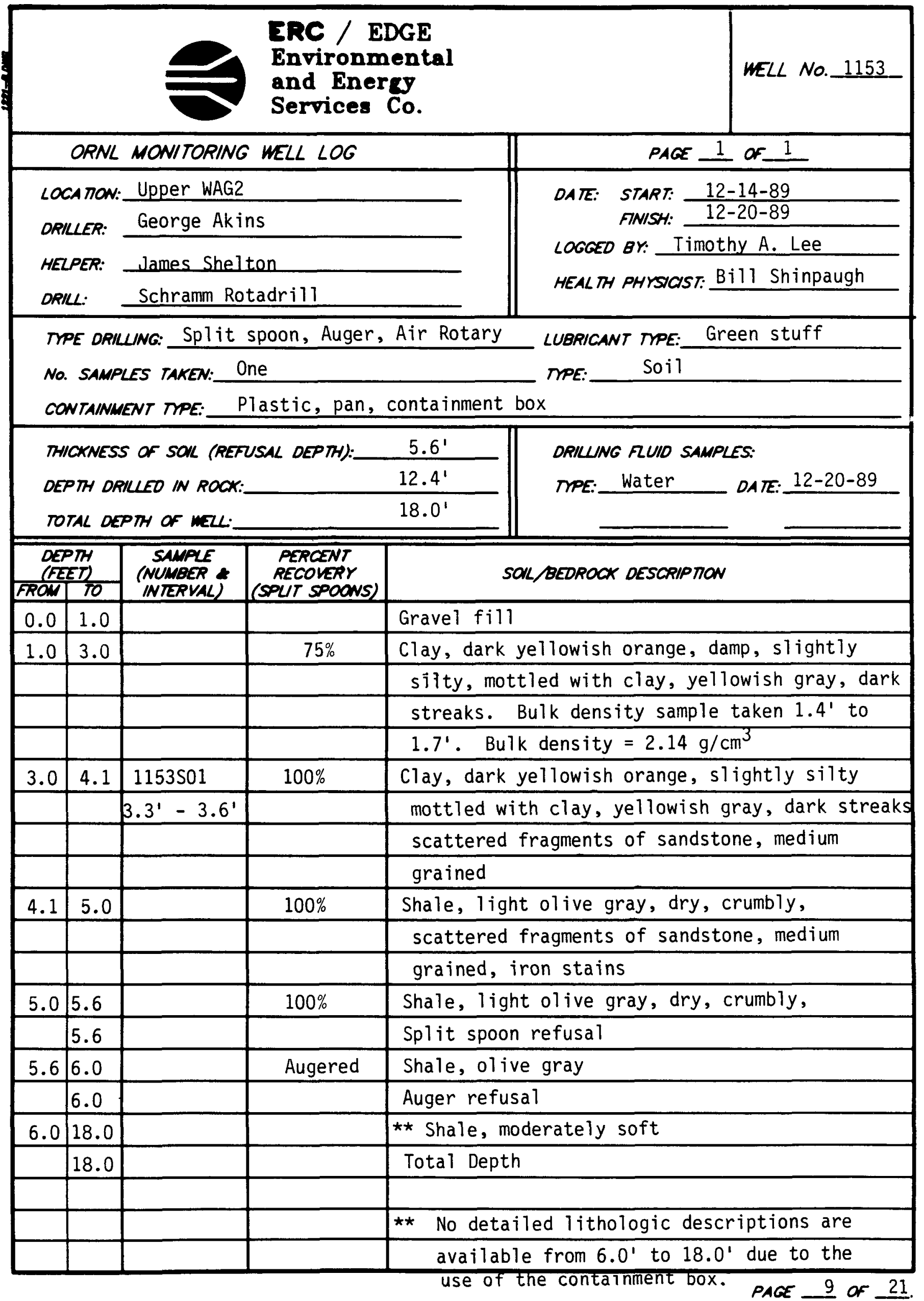




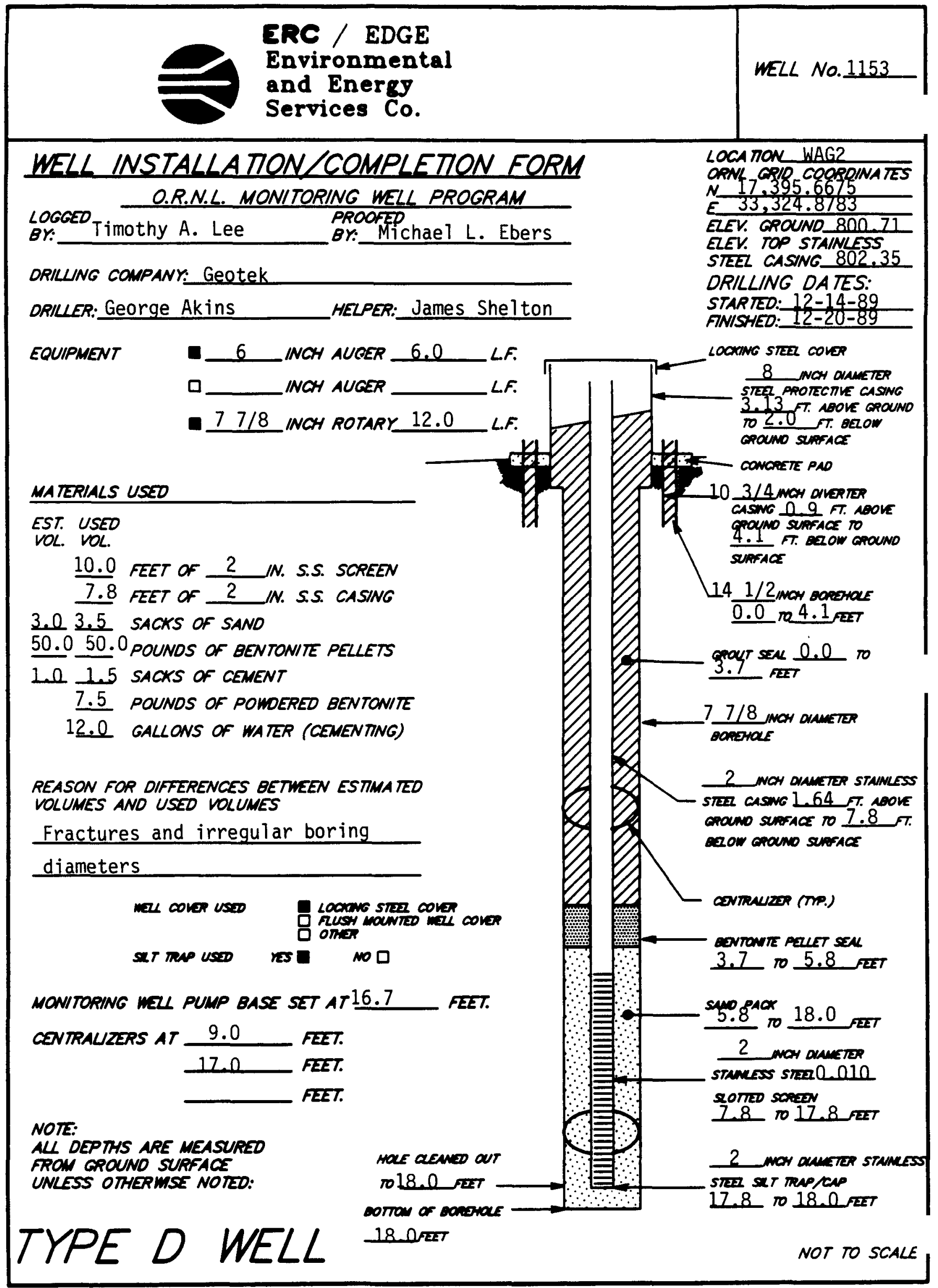

PAGE 10 of 21 . 
ERC / EDGE

Environmental

WELL NO._11 153

and Energy

Services Co.

\section{MONITORING WELL MATERIALS CERTIFICATION}

\begin{tabular}{|c|c|c|c|}
\hline ITEM/MA TERIAL & & DATE USED & BATCH NUMBER \\
\hline SAND & & $12-20-89$ & 2 \\
\hline \multirow{2}{*}{ BENTONITE } & \multirow{2}{*}{$\begin{array}{l}\text { Pellets } \\
\text { Powder }\end{array}$} & $12-20-89$ & 1 \\
\hline & & $12-21-89$ & 4 \\
\hline STAINLESS STEEL SCREEN & $\left(\begin{array}{lll}\text { PREPACKAGED } & \text { VES } \\
\text { NO }\end{array}\right)$ & $12-20-89$ & 2 \\
\hline STAINLESS STEEL CASING & (PREPACKAGED $\left.\begin{array}{c}\text { YES } \\
\text { NO }\end{array}\right)$ & $12-20-89$ & 2 \\
\hline STAINLESS STEEL CENTRALIZERS & $\left(\begin{array}{ll}\text { (PREPACKAGED } & \text { NOS } \\
\text { NO }\end{array}\right)$ & $12-20-89$ & 2 \\
\hline STAINLESS STEEL CAPS & $\left(\begin{array}{cc}\text { (PREPACKAGED } & \text { VES } \\
\text { NO }\end{array}\right)$ & $12-20-89$ & 2 \\
\hline MONITORING WELL PUMP & (PREPACKAGED 口 $\left.\begin{array}{c}\text { YES } \\
\text { NO }\end{array}\right)$ & $06-26-90$ & 7 \\
\hline GROUT & & $12-21-89$ & 4 \\
\hline WELL COVERS & & & \\
\hline SURFACE CASING & & $N / A$ & $N / A$ \\
\hline
\end{tabular}

COMMENTS:

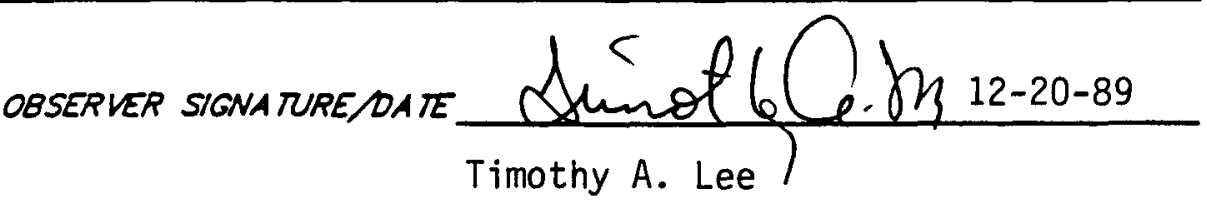

PAGE 11 of 21. 


\begin{tabular}{|l|l|}
\hline $\begin{array}{l}\text { ERC / EDGE } \\
\text { Environmental } \\
\text { and Energs } \\
\text { Services Co. }\end{array}$ & wELL No.1153 \\
\hline & $\frac{\text { POST-WELL COMPLETION }}{\text { CHECKLIST }}$ \\
\hline
\end{tabular}

\section{POST-MELL COMPLERON TASKS}

1. MUD SCRAPED FROM AUCERS SAMPLERS, ANO ALL OTHER EQUIPIENT.

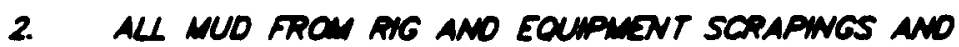
CUTINAS DISPOSID OF IN ACCOPDANCE MTH THE secarich now" priowazo.

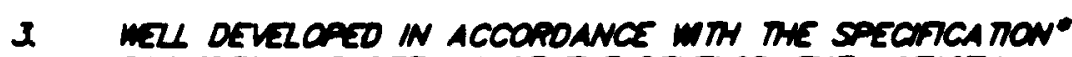

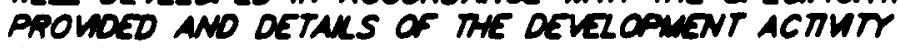
Recainoso.

4. ORULNG SIE PROPERY Y CEANED UP ATTER completion of wiL instALATION.

\begin{tabular}{|c|c|}
\hline CON & $M$ \\
\hline$D A . T$ & INITALS \\
\hline $2-14-89$ & 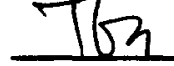 \\
\hline $12-20-89$ & \\
\hline $06-26-90$ & \pm \\
\hline $12-2$ & $r$ \\
\hline
\end{tabular}

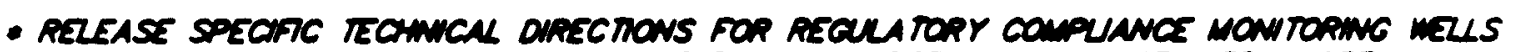
PHASE l, OAK RHOCE NAMONAL LABORA TORY, OAK RIDES M.O. $\mathrm{k}-4147$, APRK 1967.

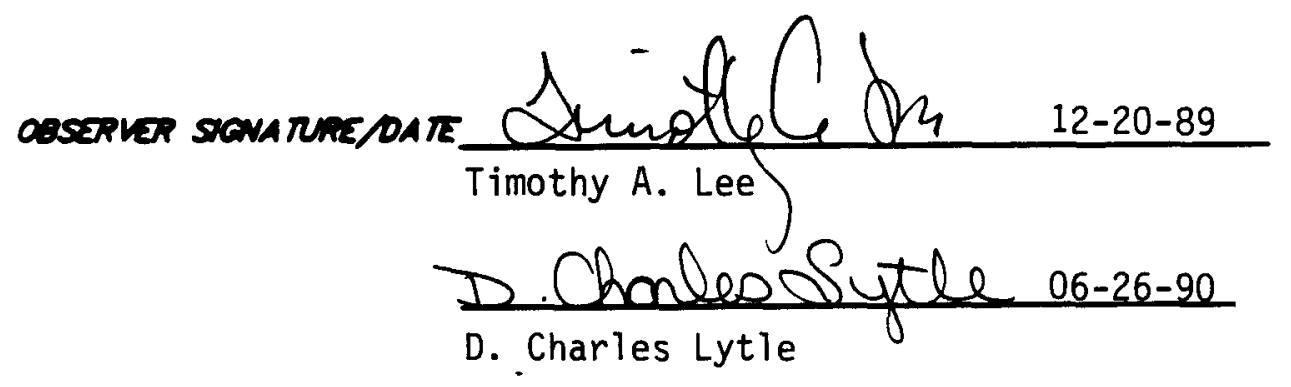


ERCE

Environmental

and Enerey

Services Co.

WELL NO.1153

Upper

LOCA MON: WAG2

\section{MONITORING WELL \\ DEVELOPMENT FORM}

DEVELOPMENT OETAILS

METHOD OF

QEVEL OPMENT: Surging and pumping

DEVELOPMENT

BEGAN DATE: $\quad 6 / 22 / 90$

TME:

OEVELOPMENT

ENOING DATE: $\quad 6 / 26 / 90$

DEVELOPMENT

OBSERVED BY: D. Charles Lytle

ONE WELL VOLUME: 5.6 GALLONS

TOTAL GALLONS PUMPED: 124 TOTAL WELL VOLUMES PUMPED: 22.1

INITAL PH: 8.2 FNAL PH: 8.5

INITAL CONOUCTUTY (KS/cm): 722 FNAL CONOUCTUTH ( $\mathrm{kS} / \mathrm{cm}): 856$

DESCRIPTON OF INITAL TUREIOITY:_ClOUdY

DESCRIPTION OF FINAL RURBIOITY:_Cl__ Clear

FNAL MEASURED TURBIDITY: 3.0 NTU'S

WEL APPROVED BY: R.C. Williams MMES

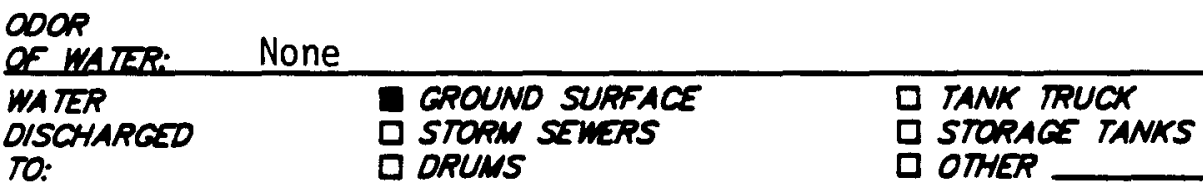

INITAL PRE-DEVELOPMENT

WATER DEPTH: 4.1 feet from ground surface

\section{OEVELOPMENT OBSERVATIONS}

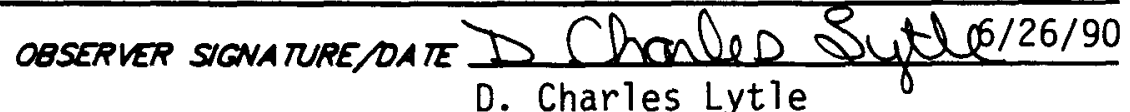




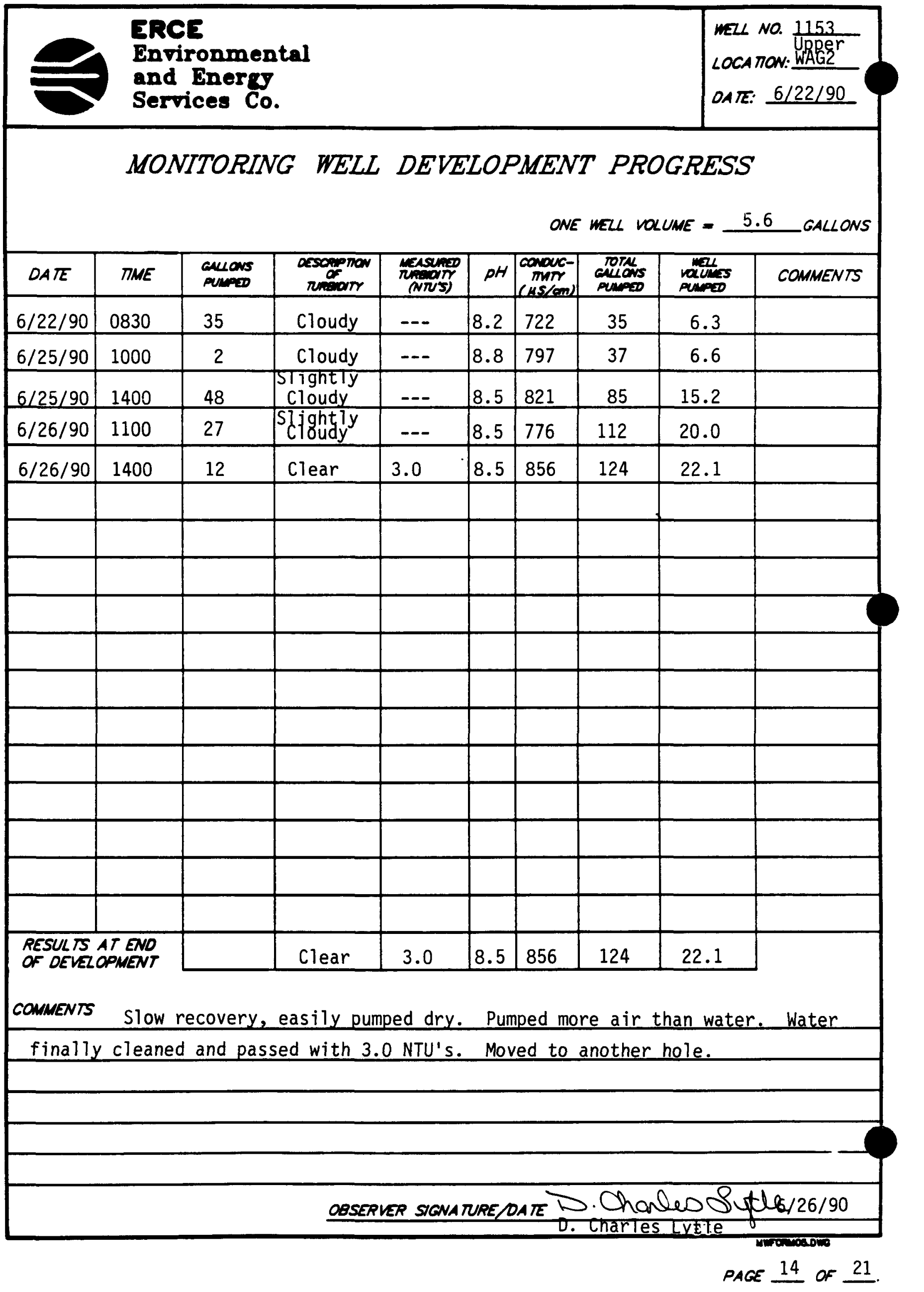




\title{
HYDRAULIC CONDUCTIVTY CALCULATIONS
}

\author{
PROGRAM SLUGT, VERSION 4.1, NOV. 1986
}

THIS PROGRAM CALCULATES MEAN TRANSMISSIVITIES FROM

SLUG-TEST DATA BASED ON TWO ANALYTICAL APPROACHES:

(1) METHOD OF COOPER, BREDEHOEFT AND PAPADOPULOS, 1967

(ARTICLE IN VOL.3, NO. 1 OF WRR ENTITLED

"RESPONSE OF A FINITE DIAMETER WELL TO AN INSTANTANEOUS CHARGE OF WATER")

(2) METHOD OF BOUWER AND RICE, 1976 (ARTICLE IN

VOL. 12 , NO.3 OF WRR ENTITLED

"A SLUG TEST FOR DETERMINING HYDRAULIC CONDUCTIVITY OF UNCONFINED AQUIFERS WITH COMPLETELY OR PARTIALLY PENETRATING WELLS")

WELL NO.: 1153

PROJECT NO.: E221-002

CITE LOCATION: U. WAG-2

EDGE, INC. FIELD INVESTIGATOR: JAMES W. CARUTHERS
DATE OF TEST: $10-29-90$

CLIENT: MMES

INPUT DATA ARE:

INNER CASING DIAMETER $=2.00$ INCHES

INNER SCREEN OR OPEN-HOLE DIAMETER $=2.00$ INCHES

DIAMETER OF DRILLED HOLE $=7.88$ INCHES

LENGTH OF SCREEN OR INTAKE PORTION $=10.00$ FEET

DEPTH FROM STATIC LEVEL TO BOTTOM OF SCREEN $=15.50$ FEET

THICKNESS OF SATURATED AQUIFER ZONE $=10.00$ FEET

DEPTH TO STATIC WATER LEVEL BELOW REF. POINT $=1.00$ FEET

ESTIMATED POROSITY OF GRAVEL PACK $=.20$

FALLING-HEAD INDEX $=1$ ("1" IF FALLING,"0" IF RISING)

NUMBER OF DEPTH-TIME DATA POINTS = 32

HO WAS COMPUTED FROM INTERCEPT OF PLOT OF LOG(H) VS. TIME

SUCCESSIVE COMPUTED

VALUES FOR HO

(FEET)

1.7981

1.8495 


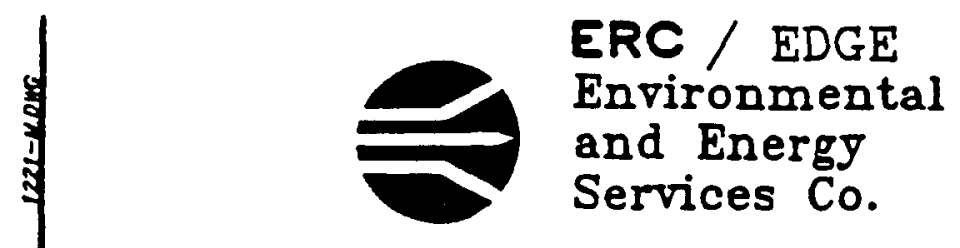

\section{HYDRAULIC CONDUCTIVTY CALCULATIONS}

TIME

(SEC )

$$
\begin{array}{r}
10.00 \\
20.00 \\
30.00 \\
40.00 \\
50.00 \\
60.00 \\
75.00 \\
90.00 \\
105.00 \\
120.00 \\
150.00 \\
180.00 \\
240.00 \\
300.00 \\
360.00 \\
420.00 \\
480.00 \\
540.00 \\
600.00 \\
720.00 \\
840.00 \\
960.00 \\
1080.00 \\
1200.00 \\
1320.00 \\
1440.00 \\
1560.00 \\
1680.00 \\
1800.00 \\
1920.00 \\
2040.00 \\
2160.00
\end{array}
$$

DEPTH TO WATER

(FEET)

4.710

4.320

4.020

3.740

3.560

3.340

3.090

2.890

2.700

2.570

2.340

2.170

1.900

1.750

1.630

1.560

1.500

1.450

1.370

1.320

1.260

1.230

1.200

1.180

1.150

1.150

1.130

1.130

1.100

1.100

1.100

1.090
HEAD

(FEET)

3.710

3.320

3.020

2.740

2.560

2.340

2.090

1.890

1.700

1.570

1.340

1.170

.900

.750

.630

.560

.500

.450

.370

.320

.260

.230

.200

.180

.150

.150

.130

.130

.100

.100

.100

.090 


\section{HYDRAULIC CONDUCTIVTY CALCULATIONS}

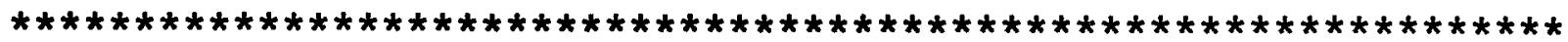

METHOD OF BOUWER AND RICE

COMPUTED RESULTS USING DIAMETER OF DRILLED HOLE:

$$
\text { PERMEABILITY }=1.73 \mathrm{E}-06 \mathrm{FT} / \mathrm{SEC}=5.27 \mathrm{E}-05 \mathrm{CM} / \mathrm{SEC}
$$

TRANSMISSIVITY $=1.73 \mathrm{E}-05 \mathrm{FT} * 2 / \mathrm{SEC}$

COMPUTED RESULTS USING DIAMETER OF CASING AND SCREEN:

$$
\text { PERMEABILITY }=2.43 \mathrm{E}-06 \mathrm{FT} / \mathrm{SEC} \quad=7.42 \mathrm{E}-05 \mathrm{CM} / \mathrm{SEC}
$$

TRANSMISSIVITY $=2.43 \mathrm{E}-05 \mathrm{FT} * * 2 / \mathrm{SEC}$ 


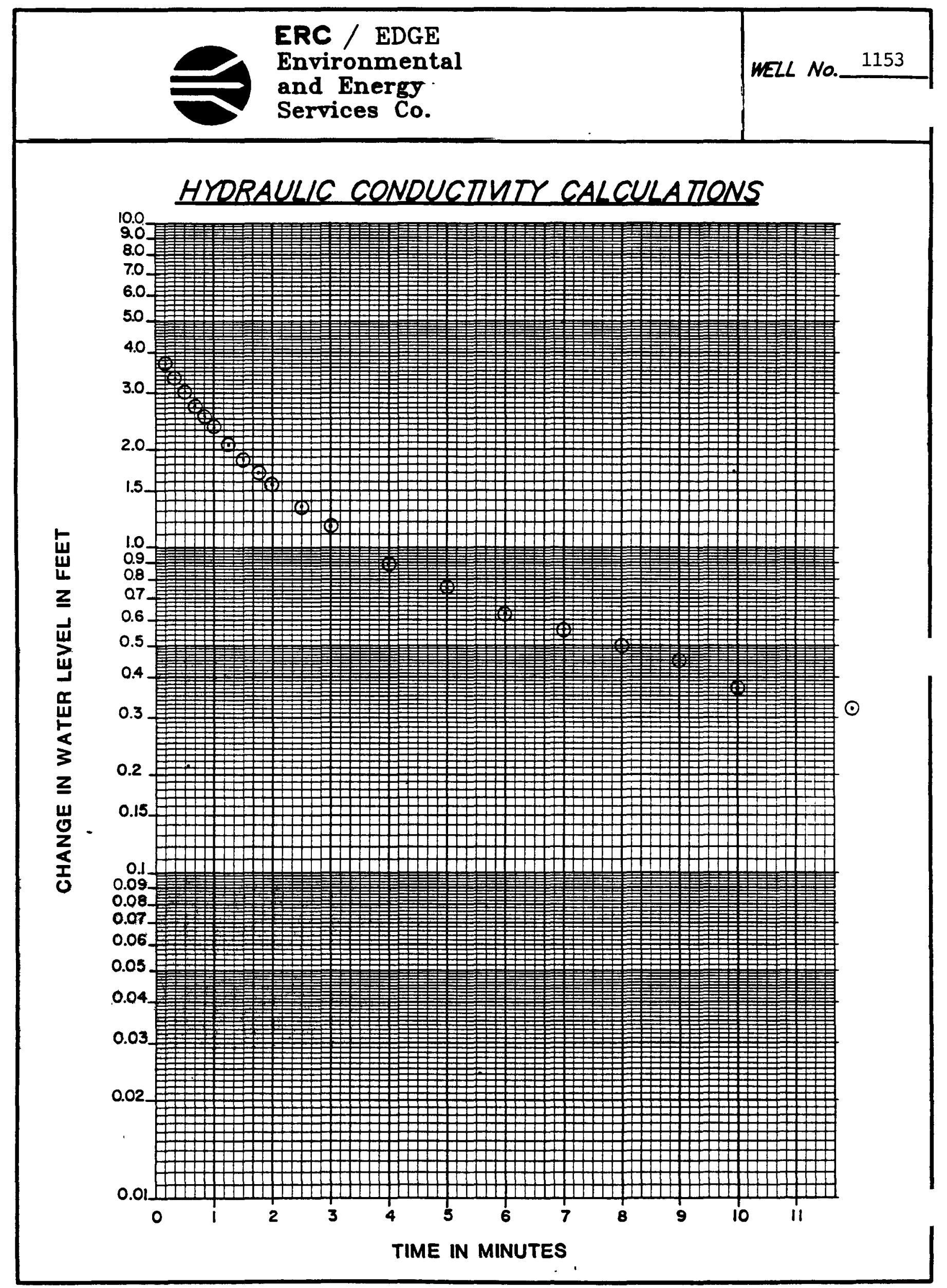


A1/GEngineering. Design \& Geosciences Group, Inc. 726 Pollssippl Parkway

P.0. Box 23010 Knorvillo, in 37933-1010

CHAIN OF CUSTODY RECORD

FOR

MARTIN MARIETTA ENERGY SYSTEMS OAK RIDGE NATIONAL LABORATORY

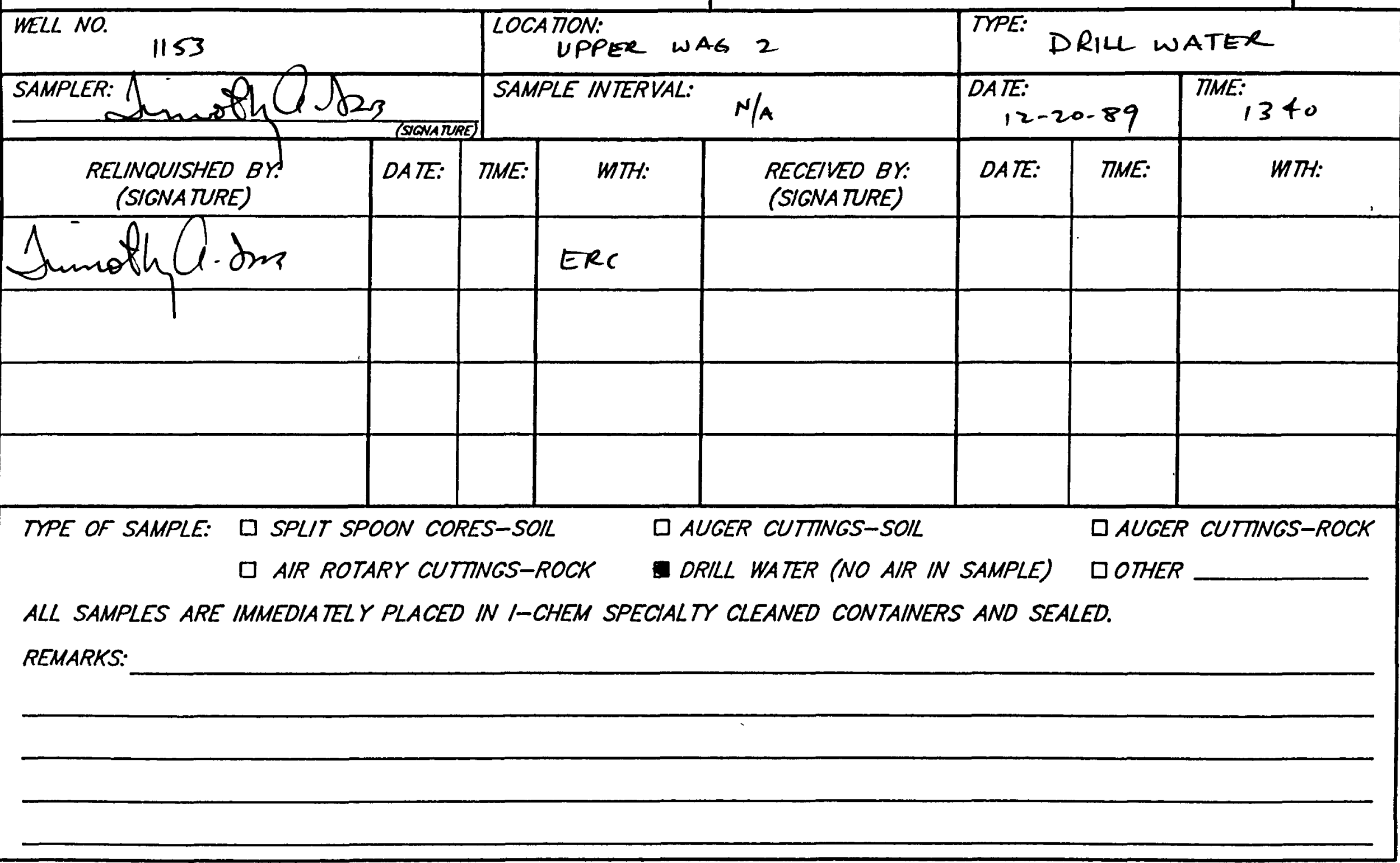




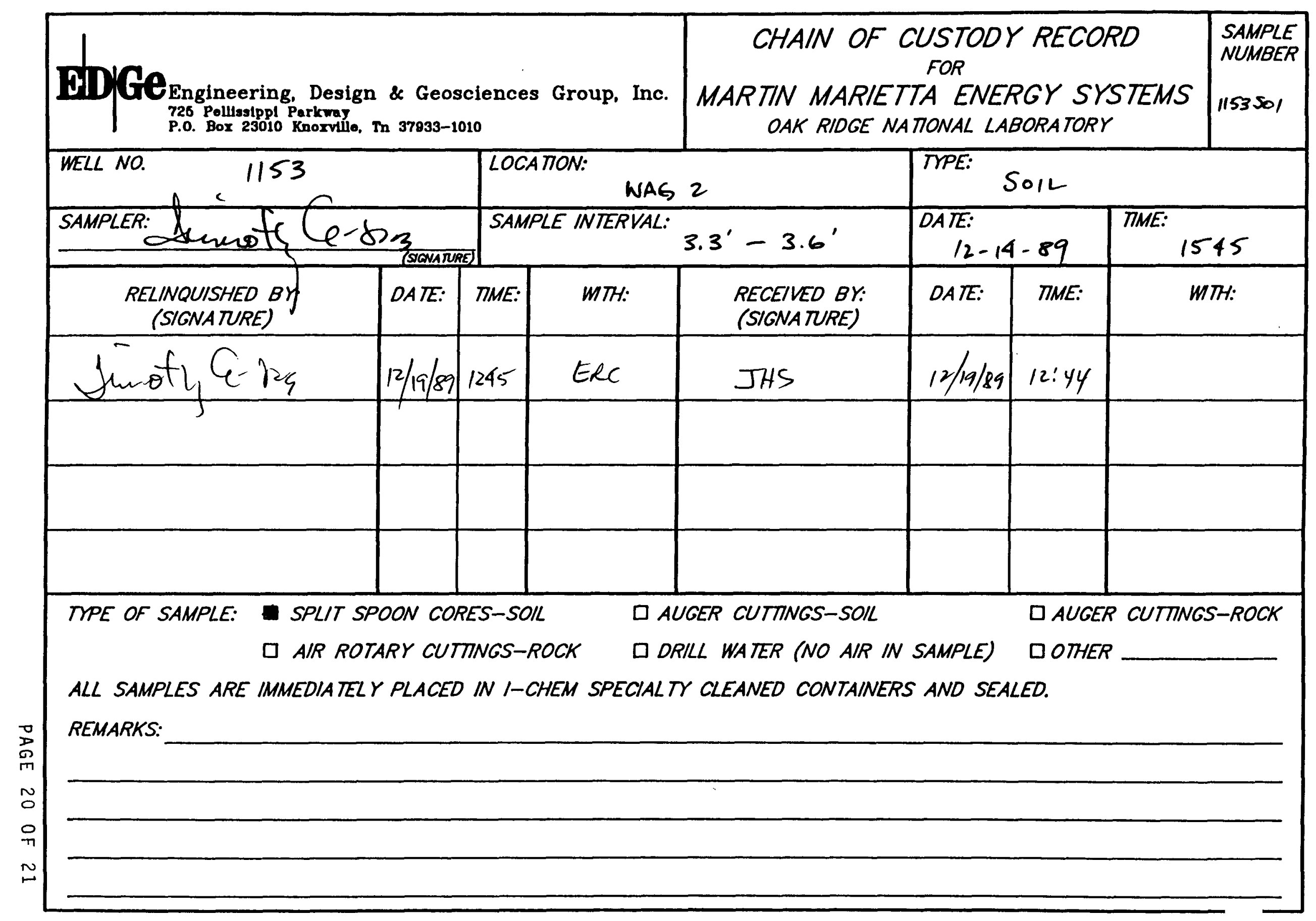




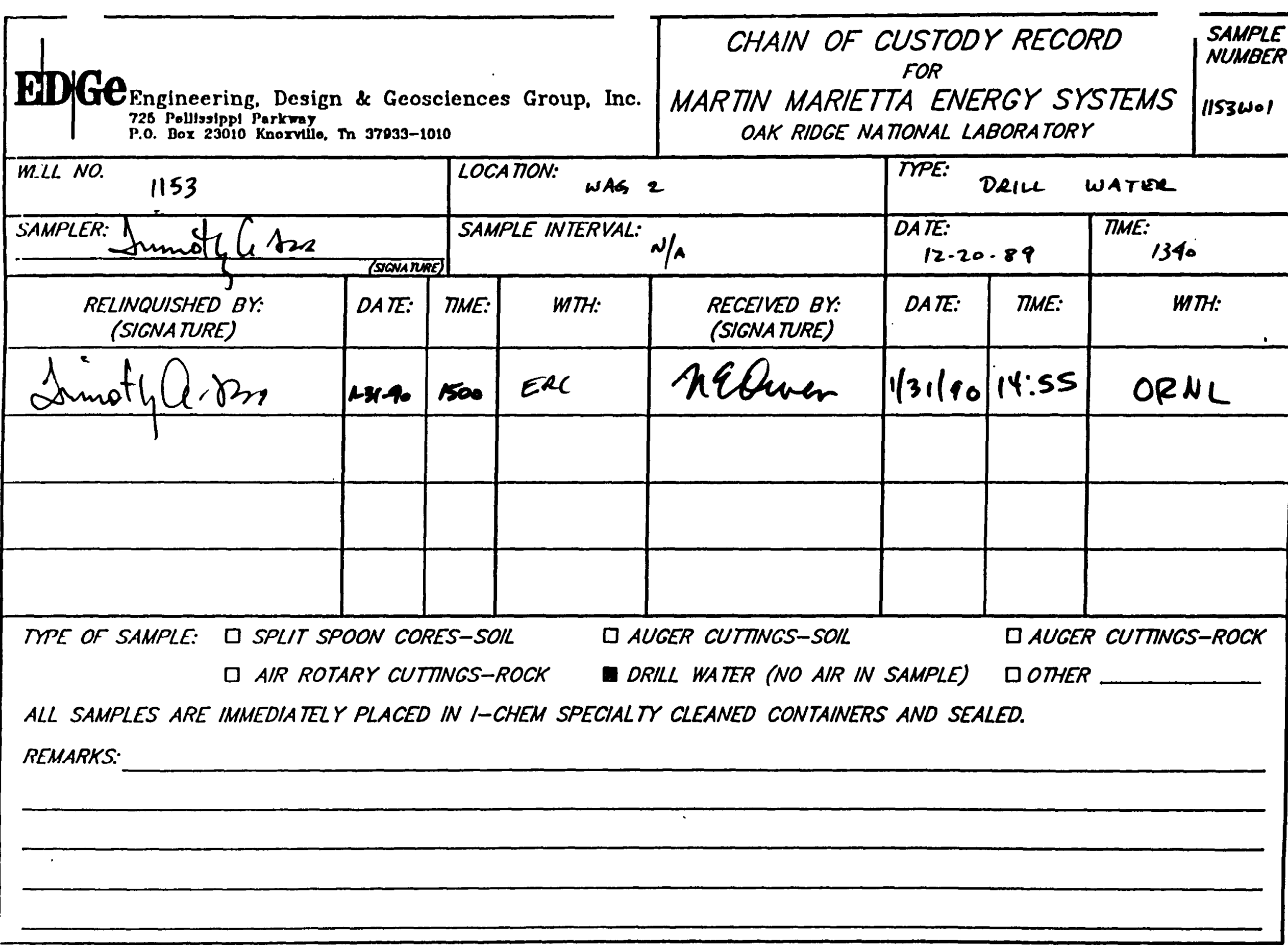


ERC / EDGE

Environmental

and Energy

Services Co.
MONITORING WELL PROGRAM

WEZL DATA NARRATVE

WEZL NO. 1154

\subsection{General Information}

\subsection{Well Location}

Monitoring well number 1154 is located in Upper WAG 2 . It is located in the eastern portion of Upper WAG 2 , approximately 200 feet south of HFIR. The location is shown on ORNL drawing number C3E20004A075. Survey coordinates for this well are $\mathrm{N} 16,191.4921$, E $32,693.8687$ (X-10 grid) or latitude $35^{\circ}-54^{\prime}-56.95^{\prime \prime}$ and longitude $84^{\circ}-18^{\prime}-04.70^{\prime \prime}$. Coordinate data were provided by Martin Marietta Energy systems. The method used for conversion from $x-10$ grid to Tennessee-Lambert state Plane Coordinates came from the publication "Tennessee valley Authority Data services Branch and Mapping Services Branch, Oak Ridge, Tennessee, DOE Plant Control, November 6, 1985, Field Book: ESS-3115, pp. 1-20." The latitude and longitude were calculated by Adams craft Herz Walker Engineering, Inc., using methods from the U.S. Coast and Geodetic Survey Publication 62-4, "state Plane Coordinates by Automatic Data Processing."

\subsection{Drilling Information}

Well number 1154 was drilled by Geotek Engineering Company. A Schramm Rotadrill rig was used to drill this boring for monitor well installation under operation of George Akins with the assistance of James Shelton. Drilling commenced on November 30, 1989, and was finished on December 6, 1989. Paragraph 2.4.1 includes a detailed discussion of the well installation and a well schematic is included on the well installation/completion form. A 
ERC / EDGE

Environmental

and Energy

Services Co.
MONITORING WEL PROGRAM

WELL DATA NARRATVE

MELL NO. 1154

synopsis of the drilling activity follows. This information was typed directly from field notes and was edited only when necessary for clarification.

11-30-89 The drill rig was mobilized to the location and set up on plastic sheeting. Split spoon samples were taken from surface to 5.0 feet. Auger refusal was also at 5.0 feet.

12-01-89 The boring was augered from surface to 4.1 feet with a 20-inch auger. Set 4.1 feet of 15 3/4-inch decontaminated diverter casing and grouted it into place. Moved rig from location.

12-05-89 The rig was moved to location and set up over hole.

12-06-89 Drilled from 5.0 feet to 15.7 feet using a 7 7/8-inch air rotary tricone bit into a containment box. Heard water flowing into hole. Set 15.3 feet of stainless steel casing and screen with a sand pack and bentonite seal. Grouted casing into place with 4 sacks cement.

This well was logged by ERC Environmental and Energy Services Co., Inc., hydrogeologist Timothy A. Lee. All well construction materials and supplies were from Martin Marietta Energy systems approved batches. The batch origin of individual items is shown on the included Monitoring Well Materials Certification form. 
2.0 Technical Information

\subsection{Decontamination Procedures}

The drilling rig, down hole tools, surface casing, stainless steel screen, stainless steel casing, centralizers, and stainless steel silt trap underwent the cleaning decontamination procedures outlined in the drilling specifications (Release specific Technical Directions for Regulatory Compliance Monitoring Wells Phase 1, Oak Ridge National Laboratory, Oak Ridge, w.0. K-4147, April 1987, pgs. 2-4). A checklist of the cleaned materials is included with this data package.

\section{$2.2000109 Y$}

The Rome Formation underlies the northern portion of Upper WAG 2 and consists of variegated shale and siltstone with beds of gray, fine grained sandstone. The Conasauga Group underlies the southern portion of Upper WAG 2 and is divided into five members. They are from north to south, the Pumpkin Valley shale, Rutledge Limestone, Rogersville Shale, Maryville Limestone, and Nolichucky shale. These rocks have undergone extensive deformation and contain many folds and faults resulting in varying strike and dips. The regional strike is 56 degrees northeast and dips of about 30 degrees to the southeast. The white Oak Creek tear fault is in Upper WAG 2. Displacement varies from 40 feet up to 350 feet. 
ERC / EDGE

Environmental

and Energy

Services Co.

MONITORING WELL PROGRAM

\section{3 sample collection}

One soil sample was collected during drilling, placed in an I-CHEM specialty cleaned glass container, sealed and submitted to Sample Receiving, Analytical Chemistry Division, Bldg. 4500S, ORNL. SOil sample 1154 S01 was collected in the split spoon interval from 3.9 feet to 4.2 feet on November 30,1989 . A drill water sample was collected from the water pump on the drill rig on December 6, 1989. Analytical results for the drill water and soil sample described above can be obtained from the Remedial Action Program data base at ORNL. Chain of custody forms for these samples are included with this data package.

A bulk density soil sample was collected from the split spoon sample interval from 3.9 feet to 4.2 feet. The sample was measured and weighed, and a bulk density of 1.94 grams $/ \mathrm{cm}^{3}$ was calculated.

The Schramm Rotadrill compressed air was sampled with a cloth filter inserted between drill rods on December 6, 1989. The sample was examined with an ultraviolet light for the presence of hydrocarbons. The filter showed no detectable signs of hydrocarbons.

\subsection{Installation and Development}

\subsubsection{Installation}

This was a Type D well. A 6-inch diameter boring was split spooned and augered from ground surface to auger refusal ( 5.0 feet). The air rotary method was required 
ERC / EDGE

Environmental

and Energy

Services Co.

MONITORING WEL PROGRAM

MEZL DATA NARRATVE

WELL No. 1154

to complete the boring to the specified total well depth. Therefore, a 20.0- inch diameter boring was augered from ground surface to 4.1 feet and a 15 3/4-inch diverter casing was installed and grouted. An 8-inch diameter boring was then drilled with an air rotary tricone roller bit from 4.1 to 15.7 feet. A 2-inch diameter stainless steel screen with welded bottom cap was installed from 15.3 to 5.1 feet. A 2-inch diameter stainless steel casing was installed above the screen at 5.1 feet and extended 2.16 feet above ground surface. A sandpack was then tremied into the annular space from 4.3 to 15.3 feet, with a 0.8 -foot bentonite pellet seal poured into the annular space above the sandpack from 3.5 to 4.3 feet. The annular space from the top of the bentonite seal to the surface was tremie- grouted with a cement/bentonite slurry. A detail of the well is included on the well installation/completion form.

\subsubsection{Well Development}

Well number 1154 was developed to remove drill cuttings, silt, and other fines. The monitoring well was developed using a Geoguard pump with an air compressor. All pumps were cleaned prior to use according to specified cleaning procedures (see Paragraph 2.1). The well was developed until a measured total of 242 gallons of water had been evacuated and the clarity of the discharge water was approved by the company representative. The final turbidity value measured at completion was 1.0 NTU. A development form showing the exact method of development and other pertinent data is appended. 


\subsubsection{Installation of Dedicated Monitoring nell Pump}

After the well was developed, a Geoguard Model No. 5614 dedicated monitoring well pump was installed on June 26 , 1990, at a depth of 13.9 feet below ground surface. These pumps are decontaminated at American sigma and are sent prepackaged. A copy of the pump certification is kept on file at ORNL.

\subsection{Hydraulic Conductivity Testing}

Well number 1154 was tested for the determination of hydraulic conductivity of the aquifer in the vicinity of the well screen. This was accomplished by instantaneously adding a known quantity of water to the monitoring well and measuring the recovery of the water level over time. The changing water levels were measured using a Druck $15 \mathrm{psig}$ pressure transducer and an Omnidata Datapod II data recorder. The hydraulic conductivity value of $4.39 \times 10^{-5} \mathrm{~cm} / \mathrm{second}$ (shown as permeability on the hydraulic conductivity calculations printout attached) was calculated using the Bouwer and Rice method. A computer printout of the hydraulic conductivity calculations is included in this data package. 
Enc / EDGE

Environmental

WELL No. 1154

\section{PRE-DRILLING CHECKLIST FOR MONITORING WELLS}

RRE-DRILUNG TASKS

1. EXCAVTION PERMIT OBTAINED

2. ALL EQUIPMENT HAS BEEN CLEANED BEFORE DRIUING.

30. SCREEN AND CASING HAVE BEEN WASHED, STEAMED, RINSED WITH DE-IONIZED OR DISTLLED WATER, RINSED WTH ISOPROPI ALCOHOL, WRAPPED WTH PROTECTVE COVERING AND STORED OFF THE GROUND.

36. PRE-PACKAGED SCREENS, CASING AND CENTRALIZERS WERE USED.

4. WORK AREA FOR SAMPLE EXAMINATION COVERED WTH CLEAN POL TETHRENE.

5. CLEAN KNIVES, GLOVES, SAMPLE JARS AND LABELS ON HAND.

6. POLYETHRENE COVER IN PLACE OVER HOLE.

7. AIR ROTARY COMPRESSED AIR SAMPLED.

\begin{tabular}{|c|c|}
\hline \multicolumn{2}{|c|}{ COMPUIANCE } \\
\hline DAIE & INIMALS \\
\hline $11-30-89$ & 324 \\
\hline $11-30-89$ & n \\
\hline$N / A$ & $N / A$ \\
\hline
\end{tabular}

$12-6-89$

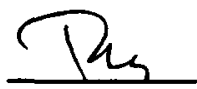

$11-30-89$

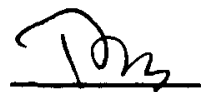

$11-30-89$

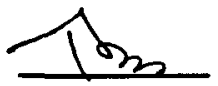

$\underline{11-30-89}$

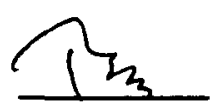

$\underline{12-6-89}$

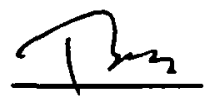

RESULTS: No hydrocarbons detected under ultraviolet light

ADDITIONAL NOTES/OBSERVATIONS:

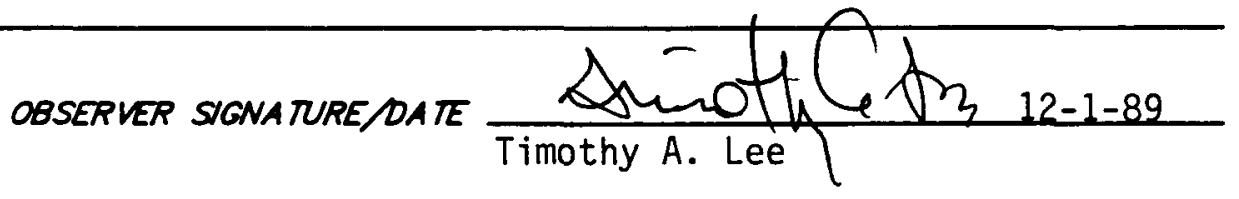


ERC / EDGE

Environmental

and Energy

WELL NO. 1154

Services Co.

\section{DECONTAMINATION CHECKLIST \\ DRILLING EQUIPMENT}

\begin{tabular}{|c|c|c|c|c|c|}
\hline EQUIPMENT & SCRAPE & $\begin{array}{l}\text { STEAN } \\
\text { CLEAN }\end{array}$ & $\begin{array}{l}\text { STEAM } \\
\text { RINSE }\end{array}$ & $\begin{array}{c}\text { ISOPROPY } \\
\text { ALCOHOL } \\
\text { RINSE }\end{array}$ & $\begin{array}{c}\text { OEIONIZED } \\
\text { WATER } \\
\text { RINSE }\end{array}$ \\
\hline$R / G$ & $x$ & $X$ & $x$ & $N / A$ & $N / A$ \\
\hline AUGERS & $x$ & $x$ & $x$ & $x$ & $x$ \\
\hline BITS & $x$ & $x$ & $x$ & $x$ & $x$ \\
\hline ROOS & $x$ & $x$ & $x$ & $x$ & $x$ \\
\hline SAMPLERS & $x$ & $x$ & $x$ & $x$ & $x$ \\
\hline PIPES & $x$ & $x$ & $x$ & $x$ & $x$ \\
\hline WORK TOOLS & $x$ & $x$ & $x$ & $x$ & $x$ \\
\hline AUGER PINS & $x$ & $x$ & $x$ & $x$ & $x$ \\
\hline & & & & & \\
\hline & & & & & \\
\hline & & & & & \\
\hline & & & & & \\
\hline
\end{tabular}

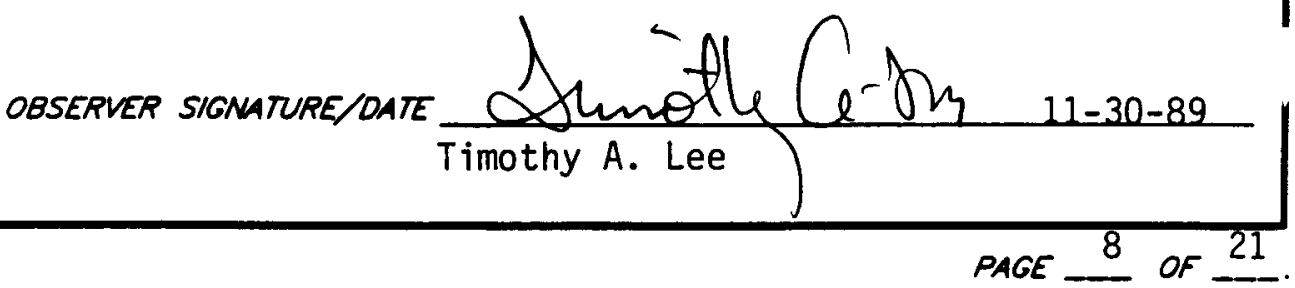




\section{ERC / EDGE
Environmental
and Energy
Services Co.}

\section{ORNL MONITORING WELL LOG}

LOCA TON: Upper WAG2

DRILLER: George Akins

HELPER: James Shelton

ORILL: Schramm Rotadrill

TRPE ORILING: Auger, Split spoon. Air Rotary

No. SAMPLES TAKEN:- One UURRICANT TPPE: Green stuff

CONTAINMENT TPPE: Plastic, pan, containment box TRPE: SO YT

DATE: START: $11-30-89$

FINISH: $12-6-89$

LOGGED BY: Timothy A. Lee

HEALTH PHYSICIST: Carl Stooksbury

THICKNESS OF SOML (REFUSAL OEPTH):- $5.0^{\prime}$ DRILING FLUID SAMPLES:

OEPTH DRILLED IN ROCK.

$10.7^{\prime}$

TRE: Water

DATE: $12-6-89$

TOTAL DEPTH OF WELL:

$15.7^{\prime}$

\begin{tabular}{|c|c|c|c|c|}
\hline \multicolumn{2}{|c|}{ 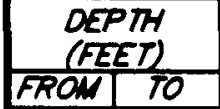 } & \multirow[t]{2}{*}{$\begin{array}{c}\text { SAMPLE } \\
\text { (NUWBER } \\
\text { NNTERVAL) }\end{array}$} & \multirow[t]{2}{*}{$\begin{array}{c}\text { PERCENT } \\
\text { RECOVERY } \\
\text { (SPUT SPOONS) }\end{array}$} & SOL/BEDROCK DESCRIPTON \\
\hline 0.0 & 1.5 & & & Gravell fill \\
\hline 1.5 & 3.5 & & $0 \%$ & \\
\hline 3.5 & 3.6 & & $100 \%$ & Gravel fill \\
\hline \multirow[t]{4}{*}{3.6} & 4.4 & 1154501 & $100 \%$ & Clay, slightly silty, moderate yellowish brown \\
\hline & & $3.9^{\prime}-4.2^{\prime}$ & & with clay, dark yellowish orange. Bulk density \\
\hline & & & & sample taken from $3.9^{\prime}$ to $4.2^{\prime}$. Bulk density \\
\hline & & & & is $1.94 \mathrm{~g} / \mathrm{cm}^{3}$ \\
\hline \multirow[t]{2}{*}{4.4} & 4.7 & & $100 \%$ & Clay, very loose moist and shale, moist, \\
\hline & & & & yellowish brown, crumbly \\
\hline \multirow[t]{4}{*}{4.7} & 5.0 & & $100 \%$ & Clay, moderate yellowish brown, moist and shale \\
\hline & & & & light olive gray, loose \\
\hline & 5.0 & & & Split spoon refusal \\
\hline & 5.0 & & & Auger refusal \\
\hline 5.0 & 6.5 & & & ** Limestone, hard \\
\hline 6.5 & 7.7 & & & Limestone, shaley, soft \\
\hline 7.7 & 8.9 & & & Limestone, hard \\
\hline 8.9 & 9.9 & & & Limestone, shaley, very soft \\
\hline 9.9 & 10.6 & & & Limestone, hard \\
\hline 10.6 & 11.6 & & & Limestone, shaley, soft \\
\hline 11.6 & 11.8 & & & Limestone, hard \\
\hline & & & & \\
\hline
\end{tabular}




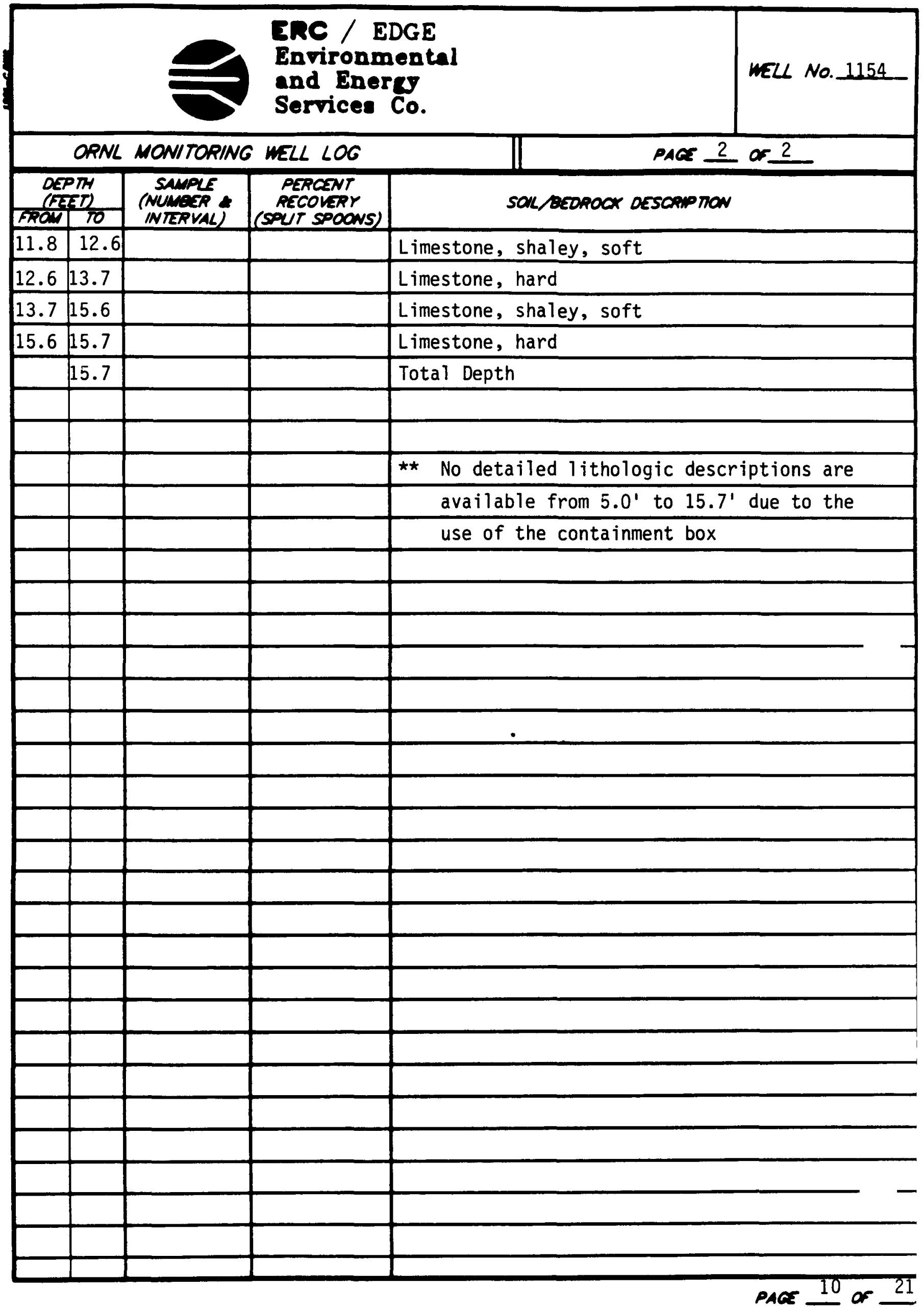




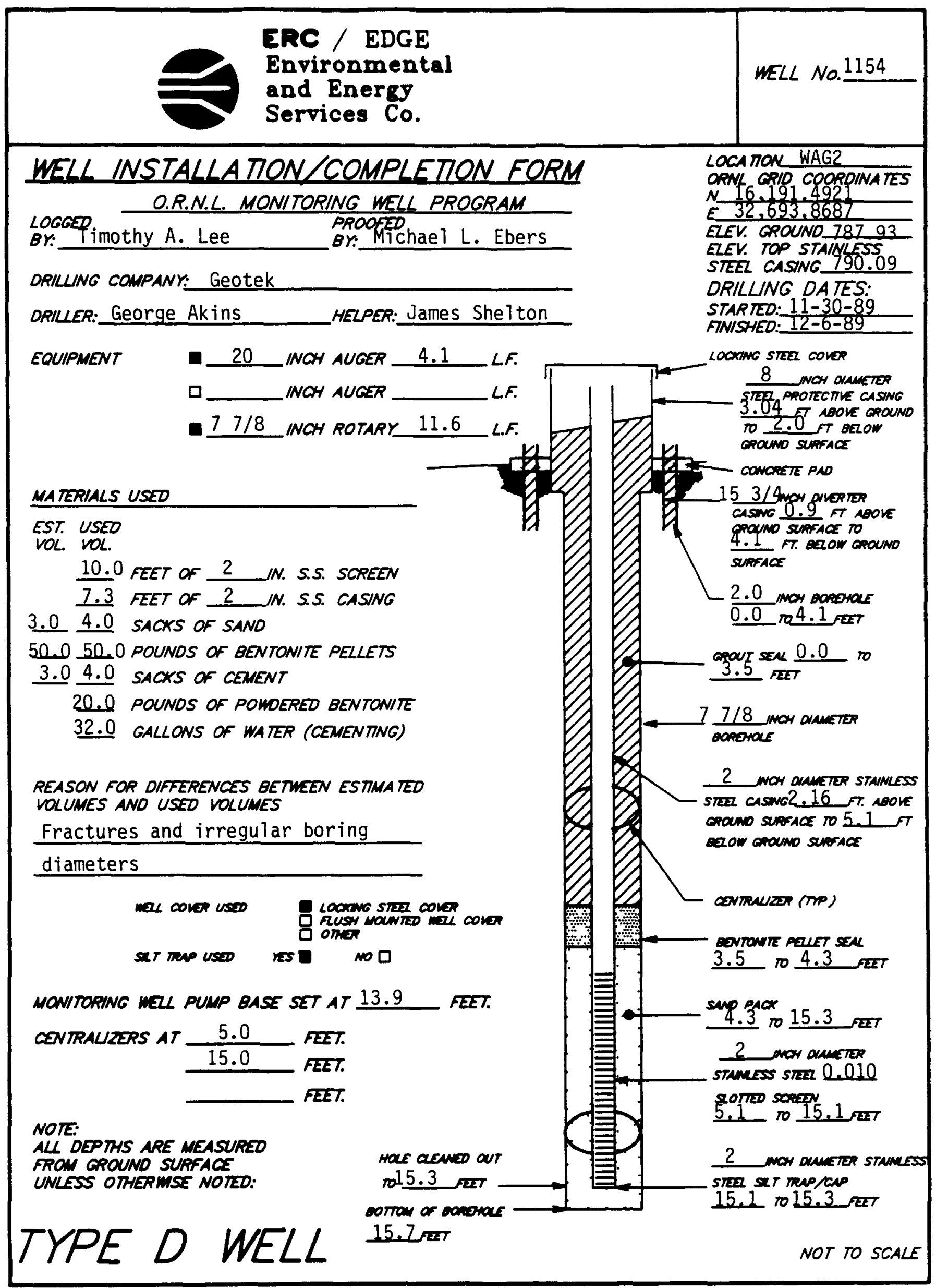

PAGE 11 of 21. 
ERC / EDGE

Environmental

WELL NO. 1154

and Energy

Services Co.

DA TE: 12-6-89

\section{MONITORING WELL MATERIALS}

CER TIFICA TION

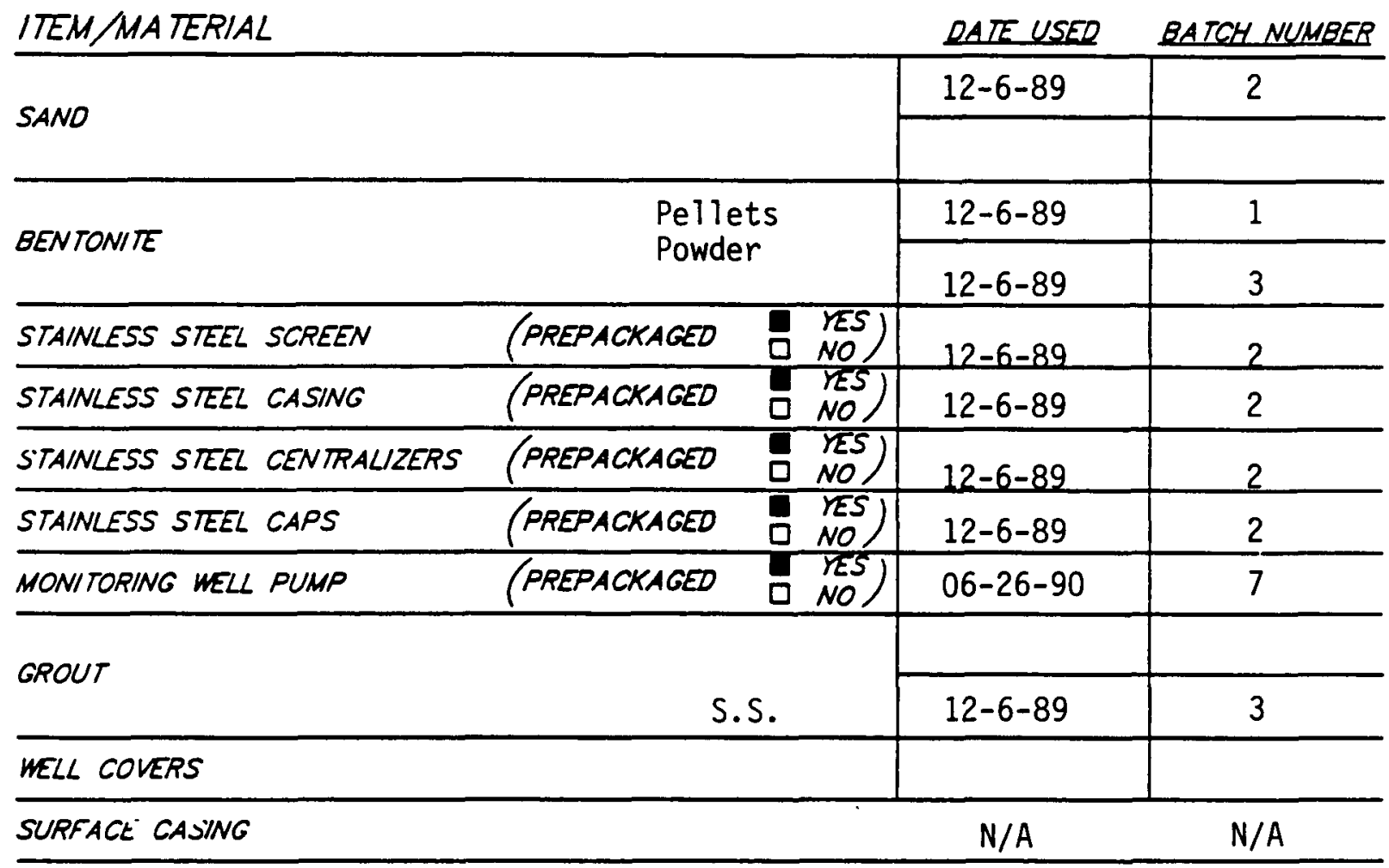

COMMENTS:

OBSERVER SIGNATURE DATE Stmothetoly 12-6-89 


\begin{tabular}{|l|l|}
\hline $\begin{array}{l}\text { EnC / EDGE } \\
\text { Environmental } \\
\text { and EnerEJ } \\
\text { Services Co. }\end{array}$ & WELL No. 1154 \\
\hline & POST-MELL COMPLETION \\
\hline CHECKLIST
\end{tabular}

\section{POST-WELL COMPLETION TASKS}

1. WU SCPAPED FROM AUCERS SMMLERS ANO ALL OTHER EOUIPIENT.

COMPLIANCE

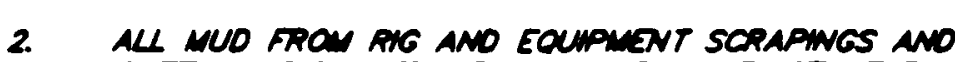
CUTIINOS OSPOSTO OF in ACCOROANCE IITH THE spearich now PROWOED.

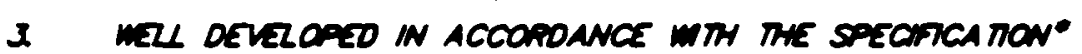

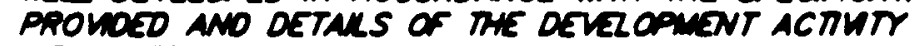
RECONOSD.

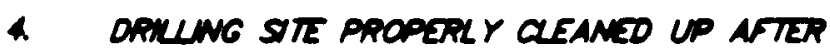
coniplenow or mul instaulinow.

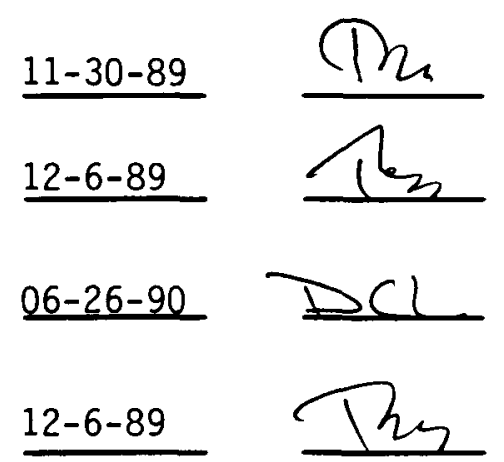

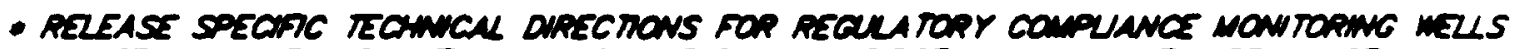

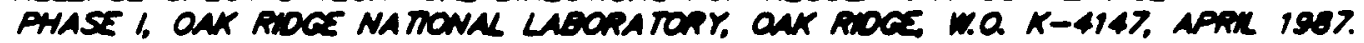
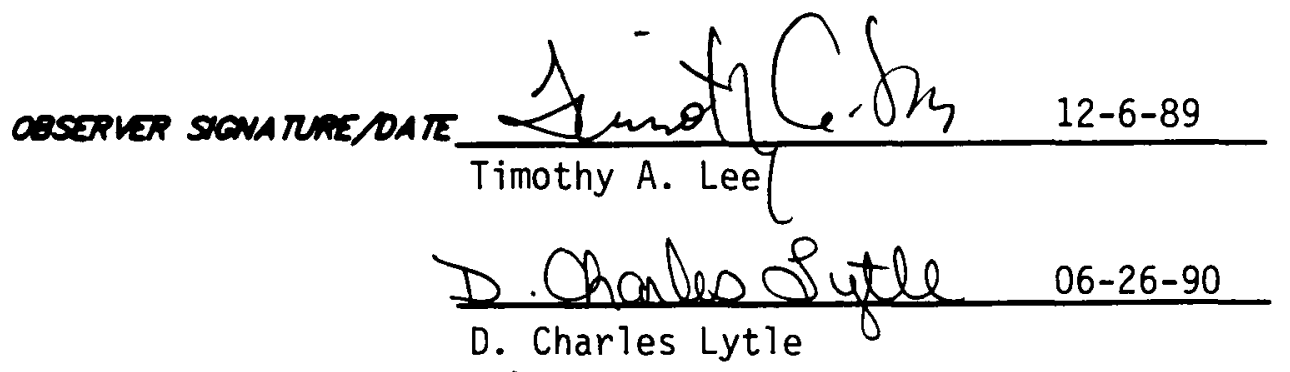

PAG 13 or 21 


\section{MONITORING WELL \\ DEVELOPMENT FORM}

OEVELOPMENT DETAILS

METHOD OF

QEVELPMENT: Surging and pumping

DEVELOPMENT

BEGAN OATE:

$6 / 21 / 90$

TME:

OEVELOPMENT

ENDING DATE:

$6 / 26 / 90$

DEVELOPMENT

OBSERVED BY:

D. Charles Lytle

ONE WELL VOLUME: GALLONS

TOTAL GALLONS PUMPED: 242 TOTAL WELL VOLUMES PUMPED: 39.0

INITAL PH: 7.8

FNAL PH: 8.1

INITAL CONDUCTUTY ( $\mathrm{S} / \mathrm{cm}$ ): 554 FNAL CONDUCRUTY ( $\mu S / \mathrm{cm}): 542$

DESCRIPTION OF INITAL TURBIOITY: Clear

DESCRIPTON OF FNAL TURBIDITY: clear

FNAL MEASURED TURBIOITY: 1.0 NTU's

WELL APPROVED Br: R.C. Williams MMES

\begin{tabular}{|c|c|c|}
\hline $\begin{array}{l}\text { ODOR } \\
\text { OF MAIER. }\end{array}$ & None & \\
\hline $\begin{array}{l}\text { WATER } \\
\text { OISCHARCED } \\
\text { TO. }\end{array}$ & $\begin{array}{l}\text { GPOUND SURFACE } \\
\text { STORM SEMERS } \\
\text { D DRUNS }\end{array}$ & $\begin{array}{l}\text { ㅁ TANK RRUCK } \\
\text { D STORAGE TANKS } \\
\text { O OTHER }\end{array}$ \\
\hline
\end{tabular}

INITAL PAE-DEVELOPMENT

WATER DEPTH: 3.9 feet from ground surface

\section{DEVELOPMENT OBSERVATIONS}

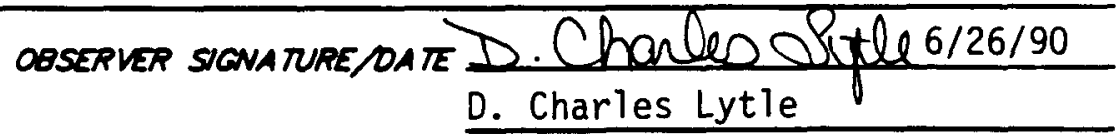




\begin{tabular}{|c|c|c|c|c|c|c|c|c|c|}
\hline & $\begin{array}{l}\text { ER } \\
\text { En } \\
\text { and } \\
\text { Ser }\end{array}$ & $\begin{array}{l}\text { Onm } \\
\text { Ener: } \\
\text { ces }\end{array}$ & & & & & & & $\begin{array}{l}\text { 10. } \frac{1154}{\text { WRRer }} \\
\text { ow: } \frac{\text { WAG2 }}{6 / 21 / 90}\end{array}$ \\
\hline & MO & TOR & $G \quad W E L$ & $D E V E$ & LOF & $M E N$ & $T P F$ & $G R E S$ & \\
\hline & & & & & & & WEL $r$ & IME $=$ & _GALLONS \\
\hline DATE & TME & $\begin{array}{c}\text { angows } \\
\text { punper }\end{array}$ & 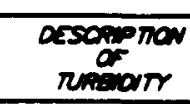 & 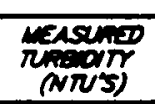 & $\rho H$ & 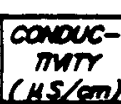 & 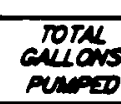 & 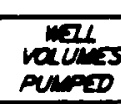 & COMMENTS \\
\hline $6 / 21 / 90$ & 0930 & 60 & Clear & 7.0 & 7.8 & 554 & 60 & 9.8 & \\
\hline $6 / 22 / 90$ & 1400 & 40 & Cloudy & --- & 8.4 & 640 & 100 & 16.1 & \\
\hline $6 / 25 / 90$ & 1000 & 61 & Cloudy & --- & 8.6 & 595 & 161 & 26.0 & \\
\hline $6 / 25 / 90$ & 1400 & 32 & $\begin{array}{l}\text { Slight iy } \\
\text { cloudy }\end{array}$ & -- & 8.4 & 555 & 193 & 31.1 & \\
\hline $6 / 26 / 90$ & 0900 & 29 & $\begin{array}{l}\text { Slightly } \\
\text { cloudy }\end{array}$ & --- & 8.0 & 536 & 222 & 35.8 & \\
\hline $6 / 26 / 90$ & 1100 & 20 & Clear & 1.0 & 8.1 & 542 & 242 & 39.0 & \\
\hline & & & & & & & & & \\
\hline & & & & & & & & & \\
\hline & & & & & & & & & \\
\hline & & & & & & & & & \\
\hline & & & & & & & & & \\
\hline & & & & & & & & & \\
\hline & & & & & & & & & \\
\hline & & & & & & & & & \\
\hline & & & & & & & & & \\
\hline & & & & & & & & & \\
\hline & & & & & & & & & \\
\hline $\begin{array}{l}\text { RESULTS } \\
\text { OF DEVEL }\end{array}$ & $\begin{array}{l}\text { END } \\
\text { MENT }\end{array}$ & & Clear & 1.0 & 8.1 & 542 & 242 & 39.0 & \\
\hline
\end{tabular}

COMMENTS Good producer, pumped dry several times, but started making more water. Passed with 1.0 NTU's and 39.0 well volumes. Moved to another hole. 


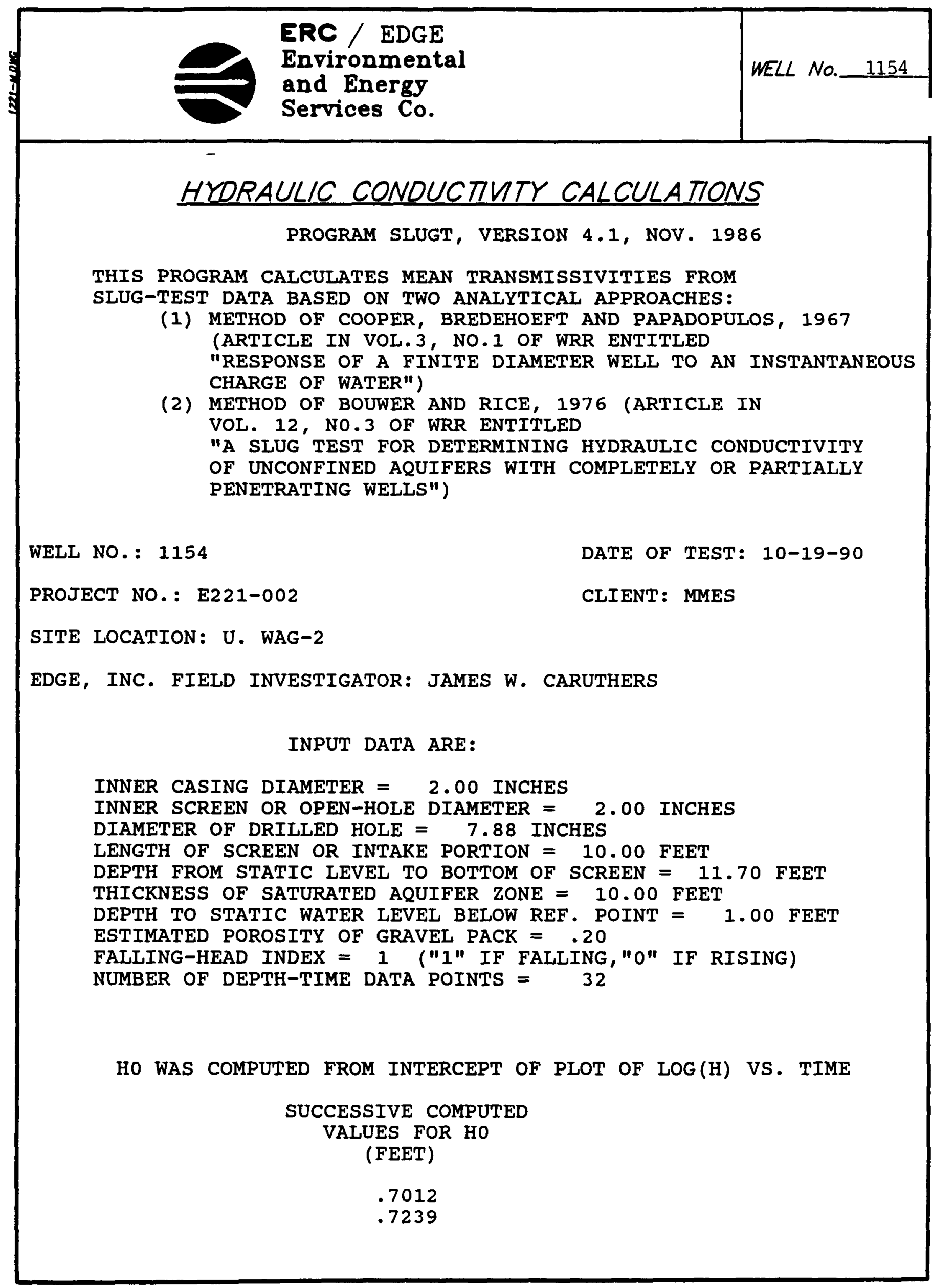




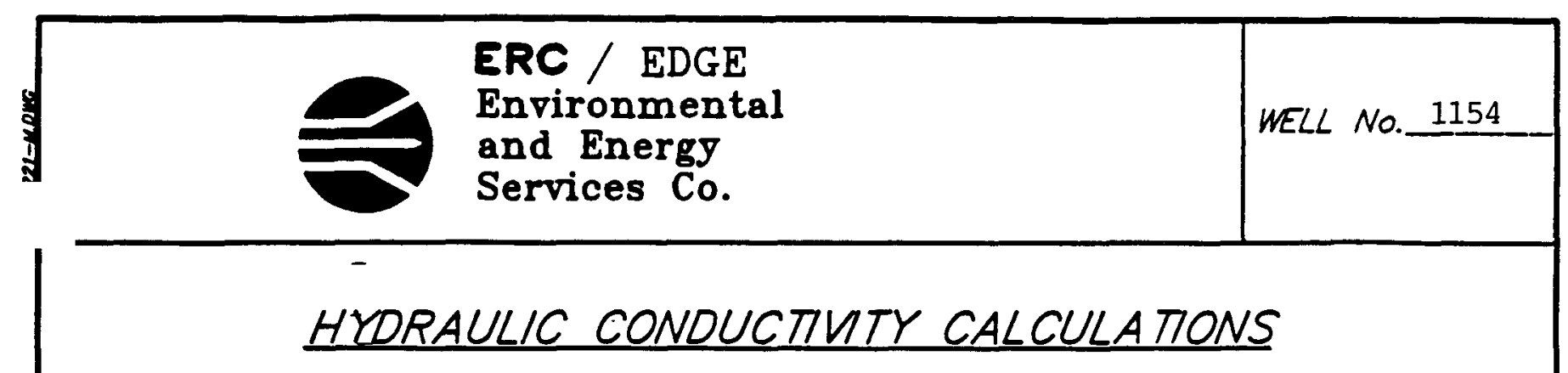

\begin{tabular}{|c|c|c|}
\hline$\left(\operatorname{SEC}^{\text {TIME }}\right)$ & $\begin{array}{l}\text { DEPTH TO WATER } \\
\text { (FEET) }\end{array}$ & $\begin{array}{l}\text { HEAD } \\
\text { (FEET) }\end{array}$ \\
\hline $\begin{array}{r}10.00 \\
20.00 \\
30.00 \\
40.00 \\
50.00 \\
60.00 \\
75.00 \\
90.00 \\
105.00 \\
120.00 \\
150.00 \\
180.00 \\
240.00 \\
300.00 \\
360.00 \\
420.00 \\
480.00\end{array}$ & $\begin{array}{l}4.290 \\
3.760 \\
3.310 \\
2.950 \\
2.630 \\
2.390 \\
2.110 \\
1.870 \\
1.720 \\
1.570 \\
1.410 \\
1.310 \\
1.210 \\
1.180 \\
1.150 \\
1.130 \\
1.140\end{array}$ & $\begin{array}{r}3.290 \\
2.760 \\
2.310 \\
1.950 \\
1.630 \\
1.390 \\
1.110 \\
.870 \\
.720 \\
.570 \\
.410 \\
.310 \\
.210 \\
.180 \\
.150 \\
.130 \\
.140\end{array}$ \\
\hline $\begin{array}{r}540.00 \\
600.00 \\
720.00 \\
840.00 \\
960.00 \\
1080.00 \\
1200.00 \\
1320.00 \\
1440.00 \\
1560.00 \\
1680.00 \\
1800.00 \\
1920.00 \\
2040.00 \\
2160.00\end{array}$ & $\begin{array}{l}1.130 \\
1.100 \\
1.090 \\
1.080 \\
1.080 \\
1.100 \\
1.090 \\
1.090 \\
1.100 \\
1.070 \\
1.080 \\
1.080 \\
1.080 \\
1.070 \\
1.060\end{array}$ & $\begin{array}{l}.130 \\
.100 \\
.090 \\
.080 \\
.080 \\
.100 \\
.090 \\
.090 \\
.100 \\
.070 \\
.080 \\
.080 \\
.080 \\
.070 \\
.060\end{array}$ \\
\hline
\end{tabular}




\section{HYDRAULIC CONDUCTIVTY CALCULATIONS}

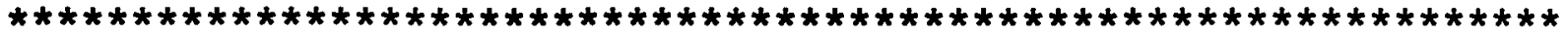

METHOD OF BOUWER AND RICE

COMPUTED RESULTS USING DIAMETER OF DRILLED HOLE:

$$
\text { PERMEABILITY }=1.44 \mathrm{E}-06 \mathrm{FT} / \mathrm{SEC}=4.39 \mathrm{E}-05 \mathrm{CM} / \mathrm{SEC}
$$

TRANSMISSIVITY $=1.44 \mathrm{E}-05 \mathrm{FT} * 2 / \mathrm{SEC}$

COMPUTED RESULTS USING DIAMETER OF CASING AND SCREEN:

$$
\text { PERMEABILITY }=2.06 \mathrm{E}-06 \mathrm{FT} / \mathrm{SEC}=6.27 \mathrm{E}-05 \mathrm{CM} / \mathrm{SEC}
$$

TRANSMISSIVITY $=2.06 \mathrm{E}-05 \mathrm{FT} * * 2 / \mathrm{SEC}$ 


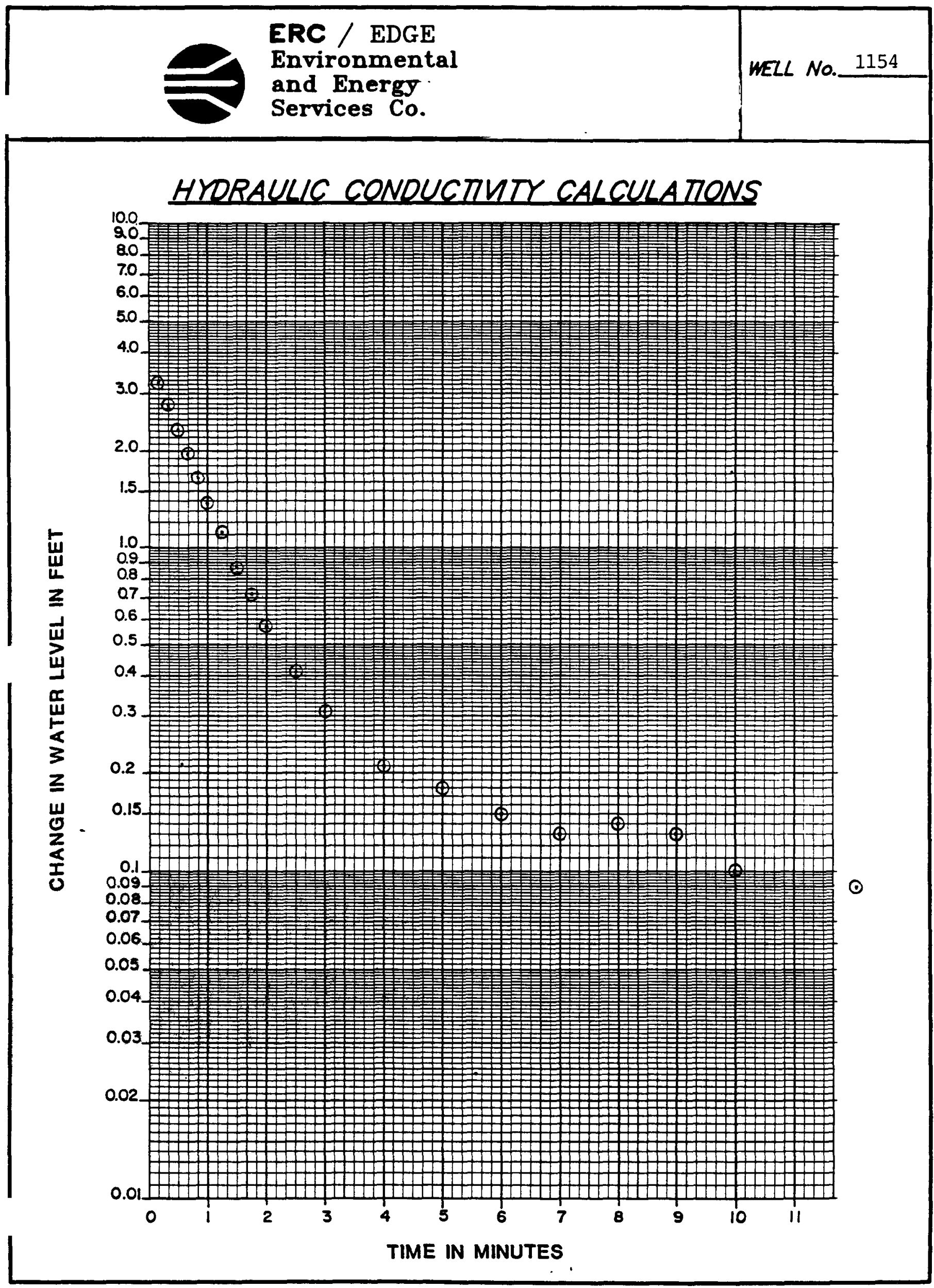

PACE 19 of 21 


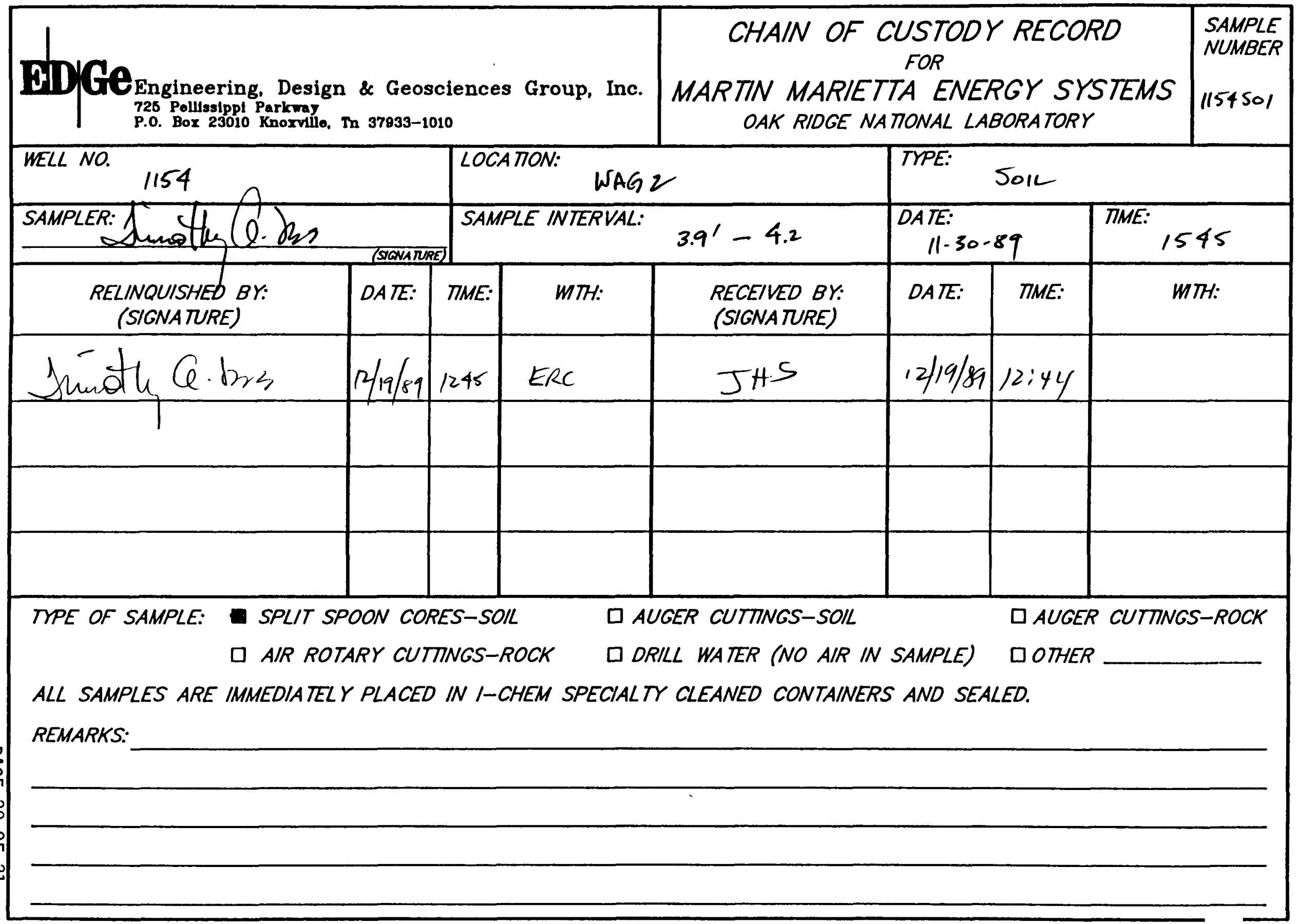




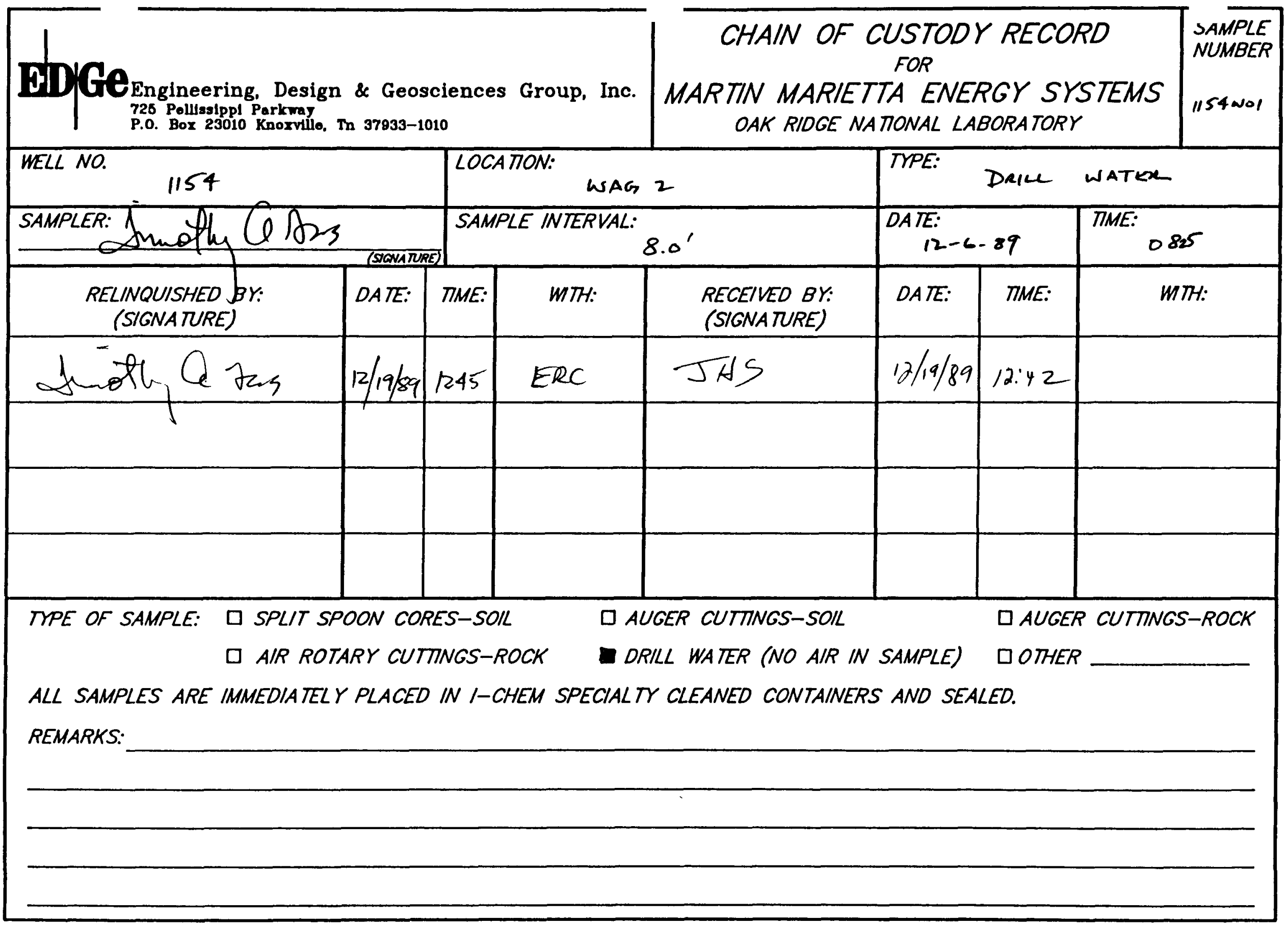




\subsection{General Information}

\subsection{Tell Location}

Monitoring well number 1155 is located in Upper WAG 2 . It is located in the south-central portion of Upper WAG 2. The location is shown on ORNL drawing number C3E20004A075. Survey coordinates for this well are N16,676.5737, E30,538.5387 (X-10 grid) or latitude $35^{\circ}-$ $54^{\prime}-49.08^{\prime \prime}$ and longitude $84^{\circ}-18^{\prime}-29.75^{\prime \prime}$. Coordinate data were provided by Martin Marietta Energy systems. The method used for conversion from X-10 grid to TennesseeLambert state Plane Coordinates came from the publication "Tennessee Valley Authority Data Services Branch and Mapping Services Branch, Oak Ridge, Tennessee, DOE Plant Control, November 6, 1985, Field Book: Ess-3115, pp. 120." The latitude and longitude were calculated by Adams Craft Herz Walker Engineering, Inc., using methods from the U.S. Coast and Geodetic survey Publication 62-4, "state Plane Coordinates by Automatic Data Processing."

\subsection{Driling Information}

Well number 1155 was drilled by Geotek Engineering Company. A Schramm Rotadrill rig was used to drill this boring for monitor well installation under operation of George Akins with the assistance of James shelton. Drilling commenced on December 1, 1989, and was finished on December 6, 1989. Paragraph 2.4.1 includes a detailed discussion of the well installation and a well schematic 
ERC / EDGE

Environmental

and Energy

Services Co.
MONITORING WELL PROGRAM

WEU DATA NARRATIVE

WEZL NO. 1155

is included on the well installation/completion form. A synopsis of the drilling activity follows. This information was typed directly from field notes and was edited only when necessary for clarification.

12-01-89 The rig was mobilized to the staked location and set up on a sheet of plastic. Split spoon samples were taken from the surface to 8.4 feet. The boring was deepened with a 6 inchauger to refusal at 9.0 feet. The boring was widened from the surface to 4.0 feet using a 20-inch auger. Set 4.0 feet of decontaminated 15 3/4-inch steel casing and grouted it into place.

12-02-89 The rig was moved from location.

12-06-89 The rig was mobilized to the location and set up on the hole. The boring was deepened from 9.0 feet to 23.0 feet using a $77 / 8$-air rotary tricone bit. Water was heard flowing into hole. Set 2 -inch stainless steel casing with sand pack and bentonite seal.

12-07-89 Grouted casing into place with 3 sacks cement.

This well was logged by ERC Environmental and Energy Services Co., Inc., hydrogeologist Timothy A. Lee. All well construction materials and supplies were from Martin Marietta Energy systems approved batches. The batch origin of individual items is shown on the included Monitoring Well Materials certification form. 


\subsection{Technical Information}

\subsection{Decontamination Procedures}

The drilling rig, down hole tools, surface casing, stainless steel screen, stainless steel casing, centralizers, and stainless steel silt trap underwent the cleaning decontamination procedures outlined in the drilling specifications (Release specific Technical Directions for Regulatory Compliance Monitoring Wells Phase 1, Oak Ridge National Laboratory, Oak Ridge, W.o. K-4147, April 1987, pgs. 2-4). A checklist of the cleaned materials is included with this data package.

\subsection{Geology}

The Rome Formation underlies the northern portion of Upper WAG 2 and consists of variegated shale and siltstone with beds of gray, fine grained sandstone. The Conasauga Group underlies the southern portion of Upper WAG 2 and is divided into five members. They are from north to south, the Pumpkin Valley shale, Rutledge Limestone, Rogersville Shale, Maryville Limestone, and Nolichucky Shale. These rocks have undergone extensive deformation and contain many folds and faults resulting in varying strike and dips. The regional strike is 56 degrees northeast with dips of about 30 degrees to the southeast. The White Oak creek tear fault is in Upper WAG 2. Displacement varies from 40 feet up to 350 feet. 
ERC / EDGE

Environmental

and Energy

Services Co.
MONITORING WELL PROGRAM

WEZL DATA NARRATVE

WELL NO. 1155

\section{3 sample collection}

One soil sample was collected during drilling, placed in an I-CHEM specialty cleaned glass container, sealed and submitted to Sample Receiving, Analytical Chemistry Division, Bldg. 4500S, ORNL. Soil sample 1155501 was collected in the split spoon interval from 5.3 feet to 5.6 feet on December 1, 1989. A drill water sample was collected from the water pump on the drill rig on December 6, 1989. Analytical results for the soil and drill water samples described above can be obtained from the Remedial Action Program data base at ORNL. Chain of custody forms for these soil samples are included with this data package.

A bulk density soil sample was collected from the split spoon sample interval from 5.3 feet to 5.6 feet. The sample was measured and weighed, and a bulk density of 2.03 grams $/ \mathrm{cm}^{3}$ was calculated.

The Schramm Rotadrill compressed air was sampled with a cloth filter inserted between drill rods on December 6 , 1989. The sample was examined with an ultraviolet light for the presence of hydrocarbons. The filter showed no detectable signs of hydrocarbons.

\subsection{Installation and Development}

\subsubsection{Installation}

This was a Type D well. A 6-inch diameter boring was split spooned and augered from ground surface to auger refusal ( 9.0 feet). The air rotary method was required 
to complete the boring to the specified total well depth. Therefore, a 22.0- inch diameter boring was augered from ground surface to 4.0 feet and a 15 1/4-inch diverter casing was installed and grouted. An 8-inch diameter boring was then drilled with an air rotary tricone roller bit from 9.0 to 23.0 feet. A 2-inch diameter stainless steel screen with welded bottom cap was installed from 12.8 to 23.0 feet. A 2-inch diameter stainless steel casing was installed above the screen at 12.8 feet and extended 1.78 feet above ground surface. A sandpack was then tremied into the annular space from 11.2 to 23.0 feet, with a 1.7 foot bentonite pellet seal poured into the annular space above the sandpack from 9.5 to 11.2 feet. The annular space from the top of the bentonite seal to the surface was tremie- grouted with a cement/bentonite slurry. A detail of the well is included on the well installation/completion form.

\subsubsection{We11 Development}

Well number 1155 was developed to remove drill cuttings, silt, and other fines. The monitoring well was developed using a Geoguard pump with an air compressor. All pumps were cleaned prior to use according to specified cleaning procedures (see Paragraph 2.1). The well was developed until a measured total of 155 gallons of water had been evacuated and the clarity of the discharge water was approved by the company representative. The final turbidity value measured at completion was $3.0 \mathrm{NTU}$ 's. A development form showing the exact method of development and other pertinent data is appended. 
After the well was developed, a Geoguard Model No. 5614 dedicated monitoring well pump was installed on June 26 , 1990, at a depth of 21.3 feet below ground surface. These pumps are decontaminated at American Sigma and are sent prepackaged. A copy of the pump certification is kept on file at ORNL.

\subsection{Hydraulic Conductivity Testing}

Well number 1155 was tested for the determination of hydraulic conductivity of the aquifer in the vicinity of the well screen. This was accomplished by instantaneously adding a known quantity of water to the monitoring well and measuring the recovery of the water level over time. The changing water levels were measured using a Druck 15 psig pressure transducer and an Omnidata Datapod II data recorder. The hydraulic conductivity value of $3.57 \times 10^{-5} \mathrm{~cm} /$ second (shown as permeability on the hydraulic conductivity calculations printout attached) was calculated using the Bouwer and Rice method. A computer printout of the hydraulic conductivity calculations is included in this data package. 
ERC / EDGE

Environmental

and Enercy

Services Co.

\section{PRE-DRILLING CHECKLIST FOR MONITORING WELLS}

\section{RRE-DRILLING TASKS}

1. EXCAVTION PERMIT OBTAINED

2. ALL EQUIPMENT HAS BEEN CLEANED BEFORE DRILING.

30. SCREEN AND CASING HAVE BEEN WASHED, STEAMED, RINSED WIH DE-IONIZED OR DISTILED WATER, RINSED WTH ISOPROPY ALCOHOL WRAPPED WTH PROTECTVE COVERING AND STORED OFF THE GROUND.

36. PRE-PACKAGED SCREENS, CASING AND CENIRALIZERS MERE USED.

4. WORK AREA FOR SAMPLE EXAMINATION COVERED MTH CLEAN POL YETHRENE.

5. CLEAN KNIVES, GLVVS, SAMPLE JARS ANO LABELS ON HAND.

6. POL VETHRENE COVER IN PLACE OVER HOLE.

7. AIR ROTARY COMPRESSED AIR SAMPLED.
COMPLIANCE

DAIE

$12-1-89$

INIRALS

$12-1-89$

(3n

$N / A$

$N / A$

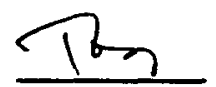

$12-1-89$

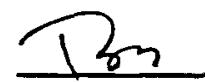

$12-1-89$

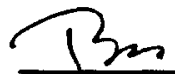

$12-6-89$

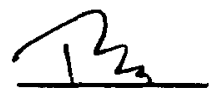

$12-6-89$

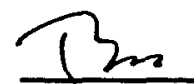

RESULTS. No hydrocarbons detected under ultraviolet light

ADOIMONAL NOTES/OBSERVATONS:

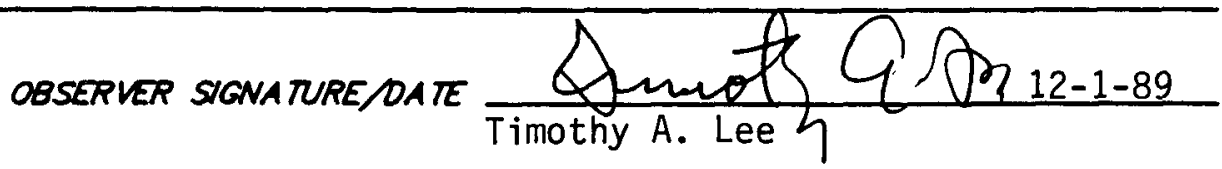


ERC / EDGE

Environmental

and Energy

WELL No._1155

Services Co.

$\frac{\text { DECONTAMINATION CHECKLIST }}{\text { DRILLING EOUIPMENT }}$

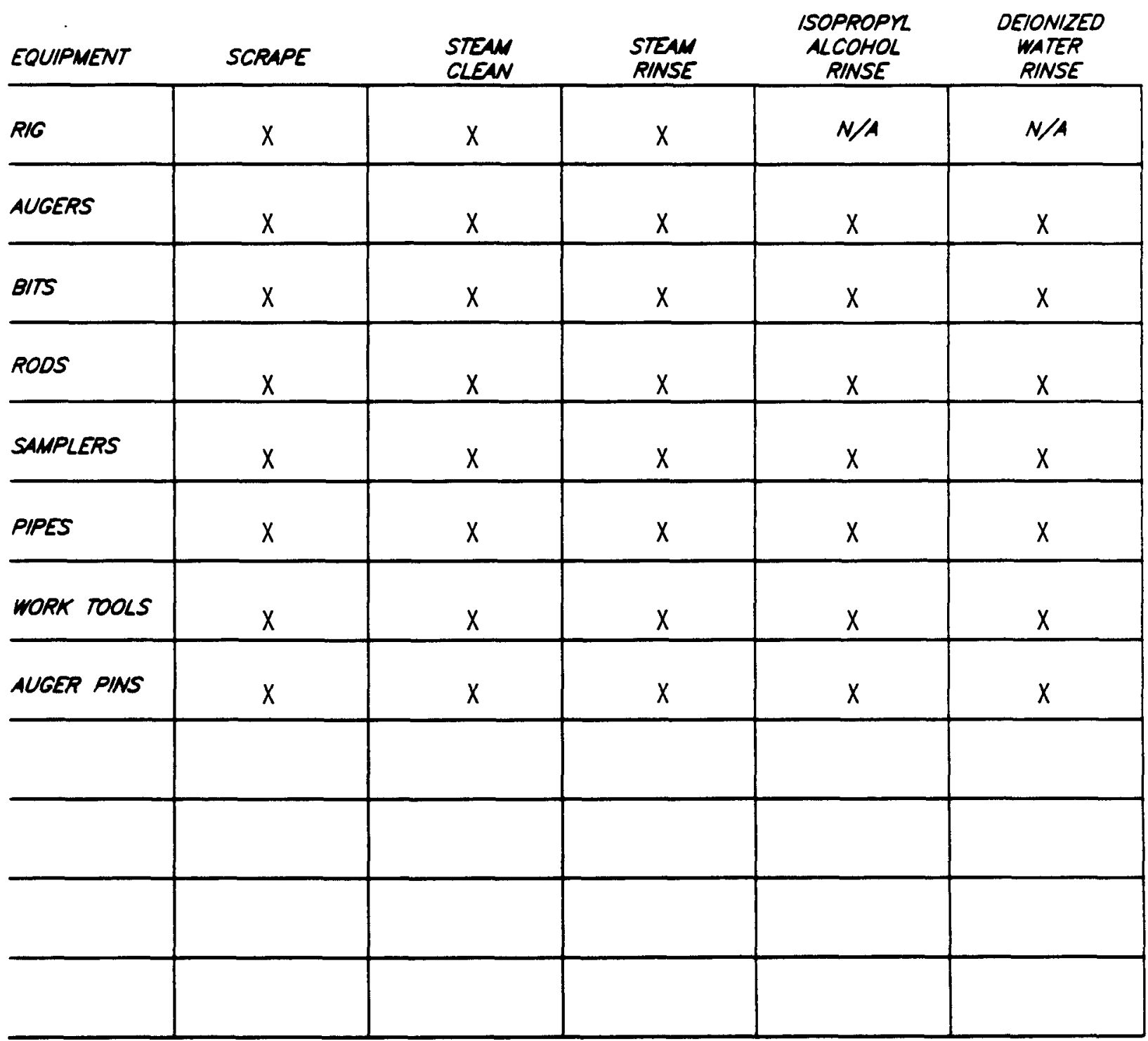

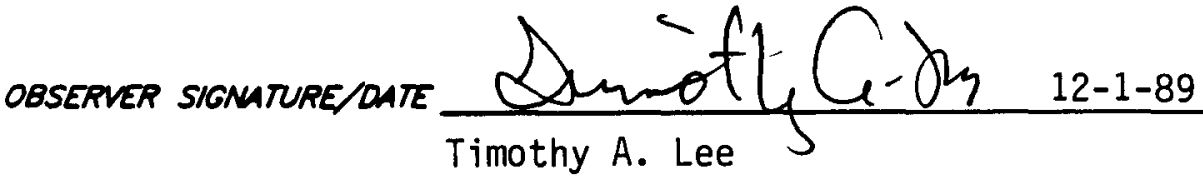
PAGE _ 8 OF 21 . 


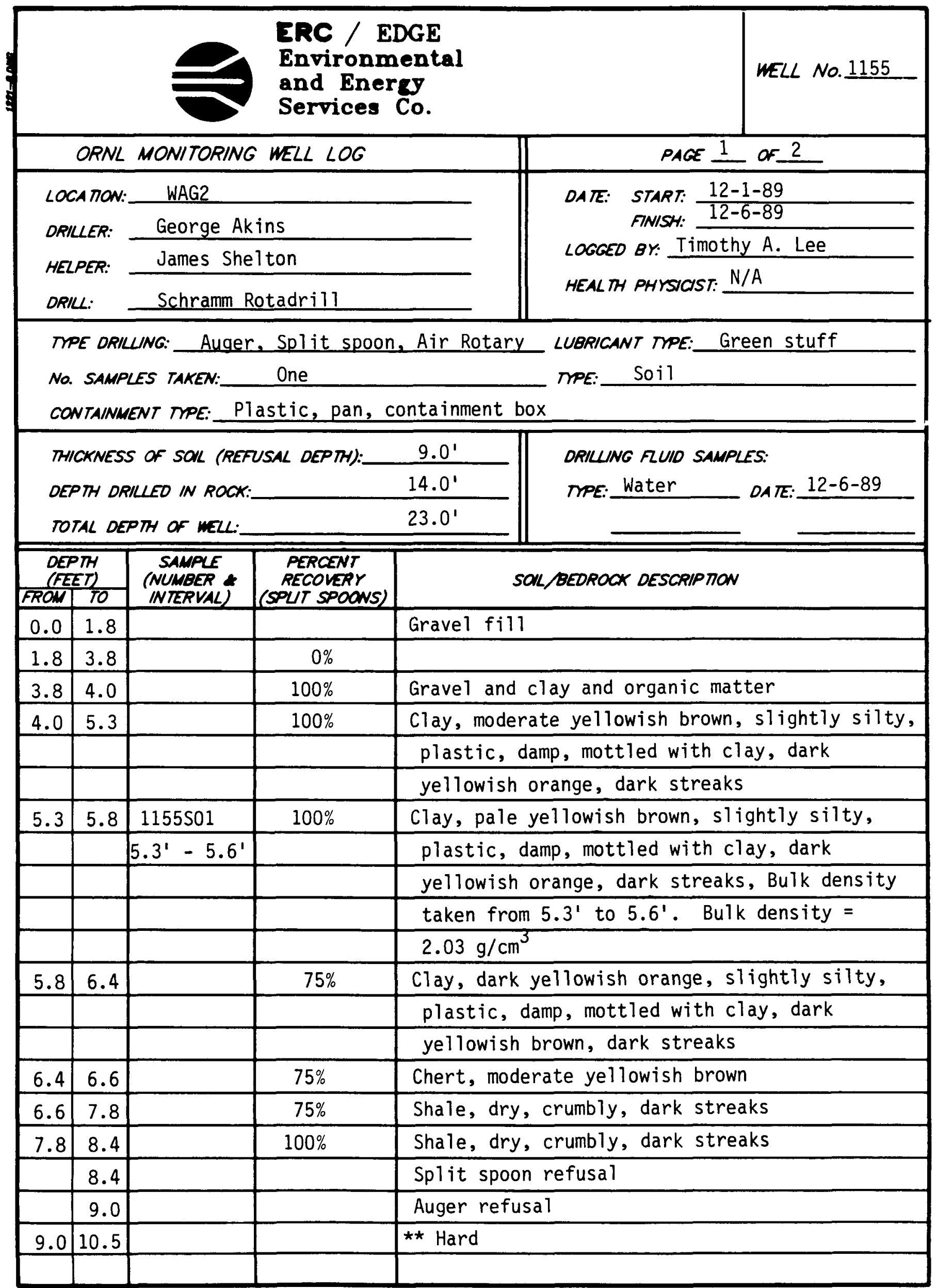




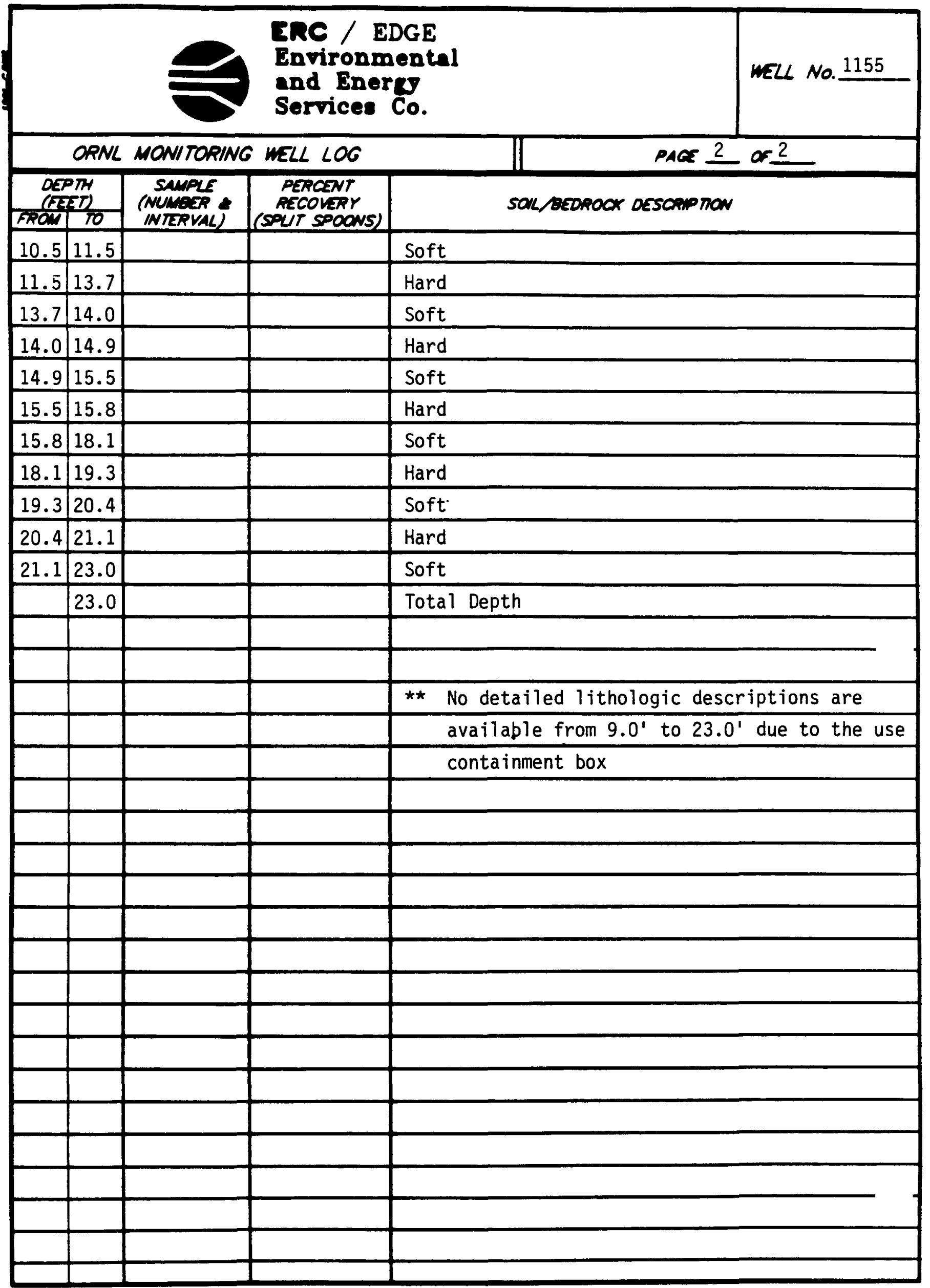




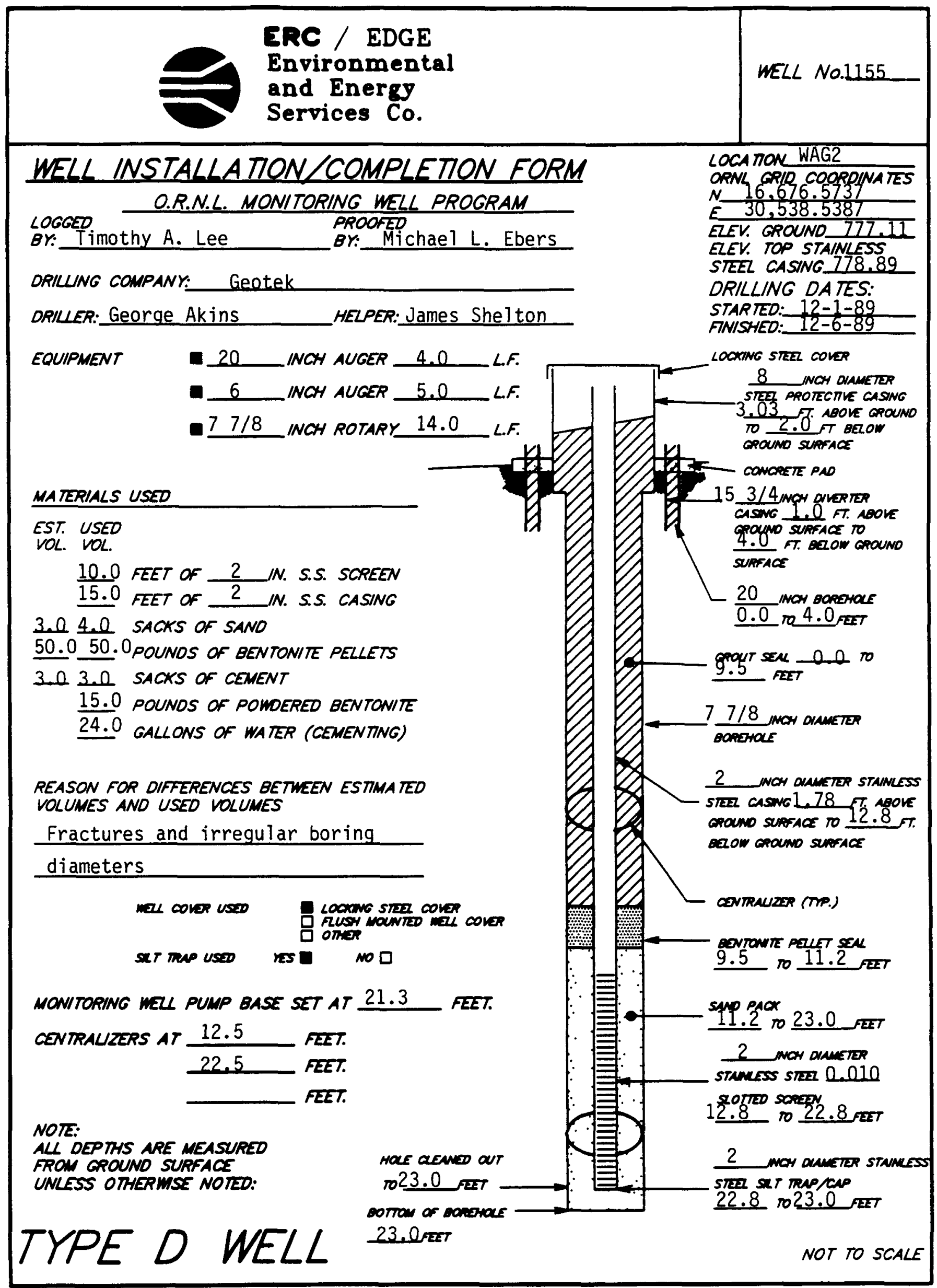

PAGE 11 of 21 
ERC / EDGE

Environmental

WELL No. 1155

and Energy

Services Co.

DATE: $12-6-89$

\section{MONITORING WELL MATERIALS \\ CERTIFICA TION}

ITEM/MATERIAL

\begin{tabular}{|c|c|c|}
\hline & DATE USED & BATCH NUMBER \\
\hline & $12-6-89$ & 2 \\
\hline & $12-6-89$ & 1 \\
\hline & $12-6-89$ & 3 \\
\hline$\left(\begin{array}{c}\text { YES } \\
\text { NO }\end{array}\right.$ & $12-6-89$ & 2 \\
\hline$\left(\begin{array}{cc}M E S \\
N O\end{array}\right)$ & $12-6-89$ & 2 \\
\hline $\begin{array}{c}\text { YES } \\
\text { NO }\end{array}$ & $12-6-89$ & 2 \\
\hline $\begin{array}{c}\text { VES } \\
\text { NO }\end{array}$ & $12-6-89$ & 2 \\
\hline$\left(\begin{array}{c}\text { YES } \\
\text { NO }\end{array}\right.$ & $06-26-90$ & 7 \\
\hline & $12-6-89$ & 3 \\
\hline & $N / A$ & $N / A$ \\
\hline
\end{tabular}

SAND

BENTONITE

Pellets

Powder

STAINLESS STEEL SCREEN

STAINLESS STEEL CASING

(PREPACKAGED

STAINLESS STEEL CENTRALIZERS (PREPACKAGED

STAINLESS STEEL CAPS

MONITORING WELL PUMP

(PREPACKAGED

(PREPACKAGED

GROUT

WELL COVERS

SURFACE CASING 
ERC / EDGE

Environmental

and Enerey

WELL NO. 1155

Services Co.

\section{POST-MELL COMPLETION CHECKLIST}

\section{BOST-MELL COMPLETON TASKS}

1. WUD SCRAPED FROM ALGERS SAMPLERS ANO ALL OTHER EOUIPUENT

2. ALI NUD FRON ANG ANO EQUMPENT SCRAPINGS ANO CUTINOS OISPOSED OF N ACCORDANCE WTH THE SPECATCA IION " PROWOED.

3. WEL DEVEZORED IN ACCOROANCE WTH THE SPECHTCA TON PROYOED ANO DETAKS OF THE OEVZZOPMENT ACTUTY RECOROED.

4. ORKUNG STE PROPERLY CLEANED UP AFTER COUPLETON OF MEL INSTALLATON.

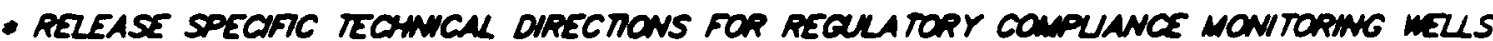
PHASE I. OAK RIOGE NATIONAL LABORATORY, OAK RIDEE W.0. K-4147, APRK 1987.

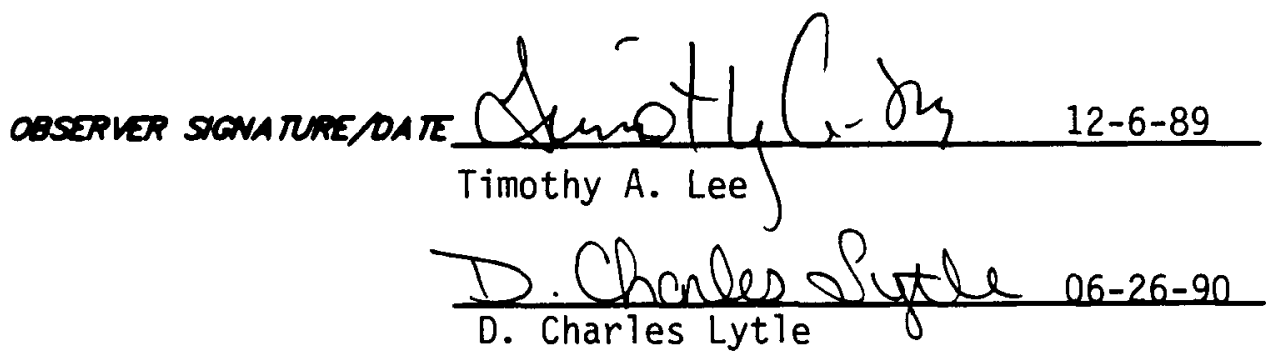




\section{MONITORING WELL \\ DEVELOPMENT FORM}

DEVELOPMENT DETAILS

METHOD OF

DEVEL OPMENT: Surging and pumping

DEVELOPMENT

BEGAN OATE:

$6 / 19 / 90$

TME:

OEVELOPMENT

ENOING DATE:

$6 / 26 / 90$

OEVELOPMENT

OBSERVED BY:

D. Charles Lytle

ONE WEL VOLUME: 7.3 GALLONS

TOTAL GALLONS PUMPED: 155 TOTAL WEL VOLUMES PUMPED: 21.2

INITAL PH: 8.6 FNAL PH: 8.5

INITAL CONOUCTUTY (KS/cm): 606 FNAL CONOUCTUTH ( $\mathrm{HS} / \mathrm{cm}): 573$

DESCRIPTION OF INITAL TURBIOITY: CloudY

DESCRIPTION OF ANAL RUREIDIT: Clear

FNAL MEASURED TURBIDITY 3.0 NTU'S

WEL APPROVED Br: R.C. Williams MMES

ODOR

QE MAIER: None

WATER

DISCHARGED

TO:

GROUND SURFACE
STOPW SEMERS
D ORUMS

D TANK TRUCK

O STORAGE TANKS

口 OTHER

INITAL PRE-OEVEOOMENT

WATRR OEPTH: 6.6 feet from ground surface

\section{DEVELOPMENT OBSERVA IONS}

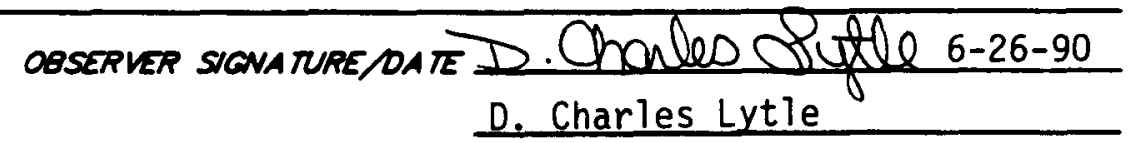




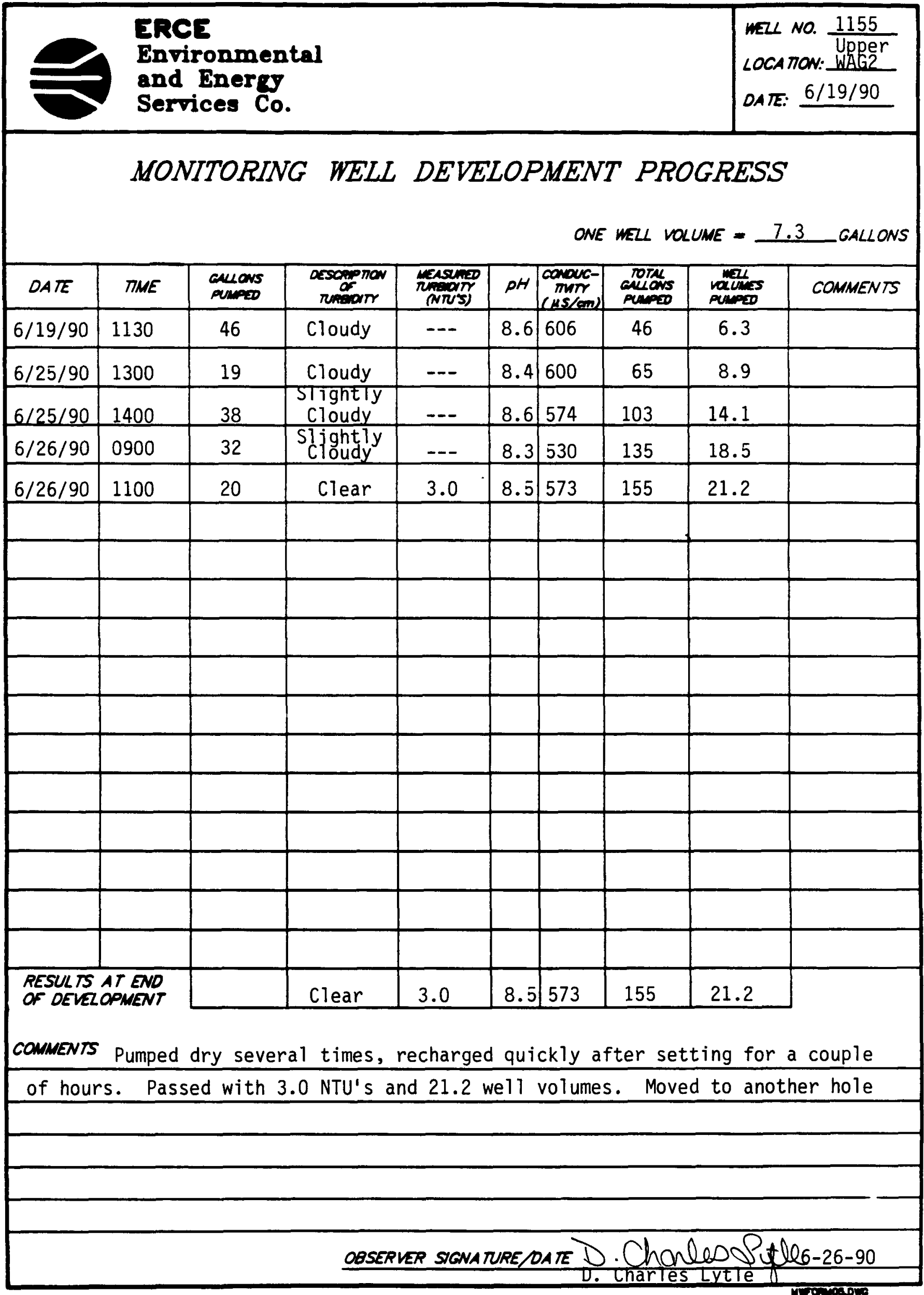




\section{HYDRAULIC CONDUCTIVTY CALCULATIONS}

PROGRAM SLUGT, VERSION 4.1, NOV. 1986

THIS PROGRAM CALCULATES MEAN TRANSMISSIVITIES FROM SLUG-TEST DATA BASED ON TWO ANALYTICAL APPROACHES:

(1) METHOD OF COOPER, BREDEHOEFT AND PAPADOPULOS, 1967 (ARTICLE IN VOL.3, NO.1 OF WRR ENTITLED "RESPONSE OF A FINITE DIAMETER WELL TO AN INSTANTANEOUS CHARGE OF WATER")

(2) METHOD OF BOUWER AND RICE, 1976 (ARTICLE IN VOL. 12 , NO.3 OF WRR ENTITLED

"A SLUG TEST FOR DETERMINING HYDRAULIC CONDUCTIVITY OF UNCONFINED AQUIFERS WITH COMPLETELY OR PARTIALLY PENETRATING WELLS")

WELL NO.: 1155

PROJECT NO.: E221-002

SITE LOCATION: U. WAG-2

EDGE, INC. FIELD INVESTIGATOR: JAMES W. CARUTHERS

INPUT DATA ARE:

INNER CASING DIAMETER $=2.00$ INCHES

INNER SCREEN OR OPEN-HOLE DIAMETER $=2.00$ INCHES

DIAMETER OF DRILLED HOLE $=7.88$ INCHES

LENGTH OF SCREEN OR INTAKE PORTION $=10.00$ FEET

DEPTH FROM STATIC LEVEL TO BOTTOM OF SCREEN $=14.40$ FEET

THICKNESS OF SATURATED AQUIFER ZONE $=10.00$ FEET

DEPTH TO STATIC WATER LEVEL BELOW REF. POINT $=1.00$ FEET

ESTIMATED POROSITY OF GRAVEL PACK $=.20$

FALLING-HEAD INDEX $=1$ ("1" IF FALLING, "0" IF RISING)

NUMBER OF DEPTH-TIME DATA POINTS = 32

HO WAS COMPUTED FROM INTERCEPT OF PLOT OF LOG(H) VS. TIME

SUCCESSIVE COMPUTED

VALUES FOR HO

(FEET)

3.4371

3.4800 


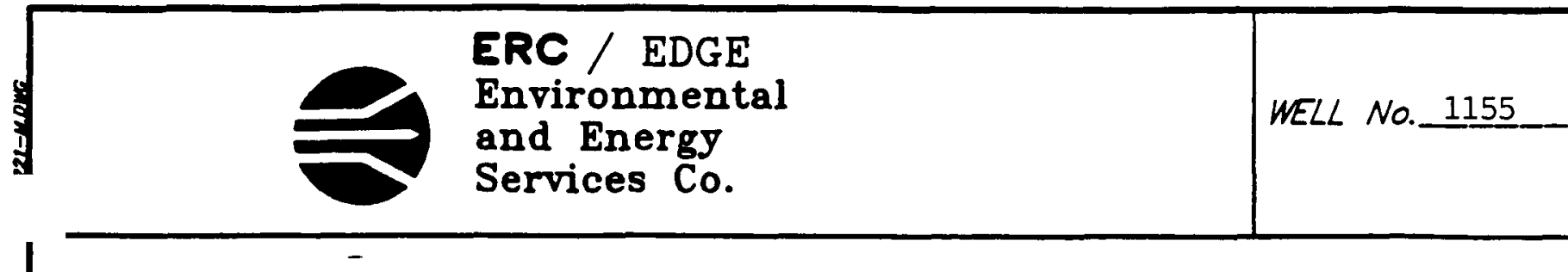

\section{HYDRAULIC CONDUCTIVTY CALCULATIONS}

\begin{tabular}{|c|c|c|}
\hline$\left(\operatorname{SEC}^{\text {TIME }}\right)$ & $\begin{array}{l}\text { DEPTH TO WATER } \\
\text { (FEET) }\end{array}$ & $\begin{array}{r}\text { HEAD } \\
(\text { FEET) }\end{array}$ \\
\hline $\begin{array}{r}10.00 \\
20.00 \\
30.00 \\
40.00 \\
50.00 \\
60.00 \\
75.00 \\
90.00 \\
105.00 \\
120.00 \\
150.00 \\
180.00 \\
240.00 \\
300.00 \\
360.00 \\
420.00 \\
480.00\end{array}$ & $\begin{array}{l}5.130 \\
5.030 \\
4.920 \\
4.820 \\
4.740 \\
4.670 \\
4.540 \\
4.420 \\
4.300 \\
4.200 \\
4.000 \\
3.820 \\
3.480 \\
3.240 \\
3.010 \\
2.810 \\
2.650\end{array}$ & $\begin{array}{l}4.130 \\
4.030 \\
3.920 \\
3.820 \\
3.740 \\
3.670 \\
3.540 \\
3.420 \\
3.300 \\
3.200 \\
3.000 \\
2.820 \\
2.480 \\
2.240 \\
2.010 \\
1.810 \\
1.650\end{array}$ \\
\hline $\begin{array}{r}540.00 \\
600.00 \\
720.00 \\
840.00 \\
960.00 \\
1080.00 \\
1200.00 \\
1320.00 \\
1440.00 \\
1560.00 \\
1680.00 \\
1800.00 \\
1920.00 \\
2040.00 \\
2160.00\end{array}$ & $\begin{array}{l}2.520 \\
2.370 \\
2.190 \\
2.040 \\
1.900 \\
1.790 \\
1.690 \\
1.630 \\
1.570 \\
1.530 \\
1.500 \\
1.460 \\
1.450 \\
1.400 \\
1.360\end{array}$ & $\begin{array}{r}1.520 \\
1.370 \\
1.190 \\
1.040 \\
.900 \\
.790 \\
.690 \\
.630 \\
.570 \\
.530 \\
.500 \\
.460 \\
.450 \\
.400 \\
.360\end{array}$ \\
\hline
\end{tabular}




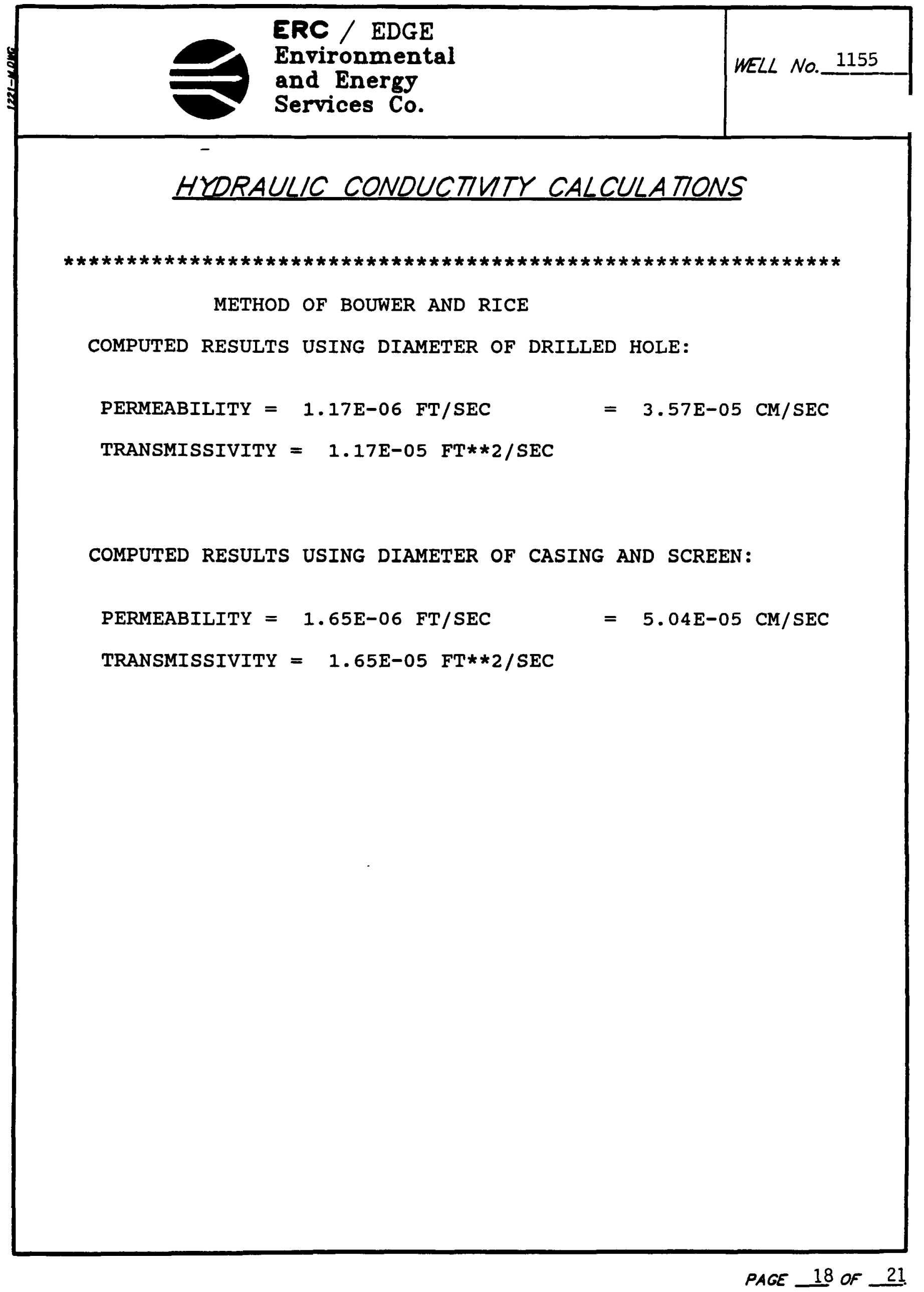




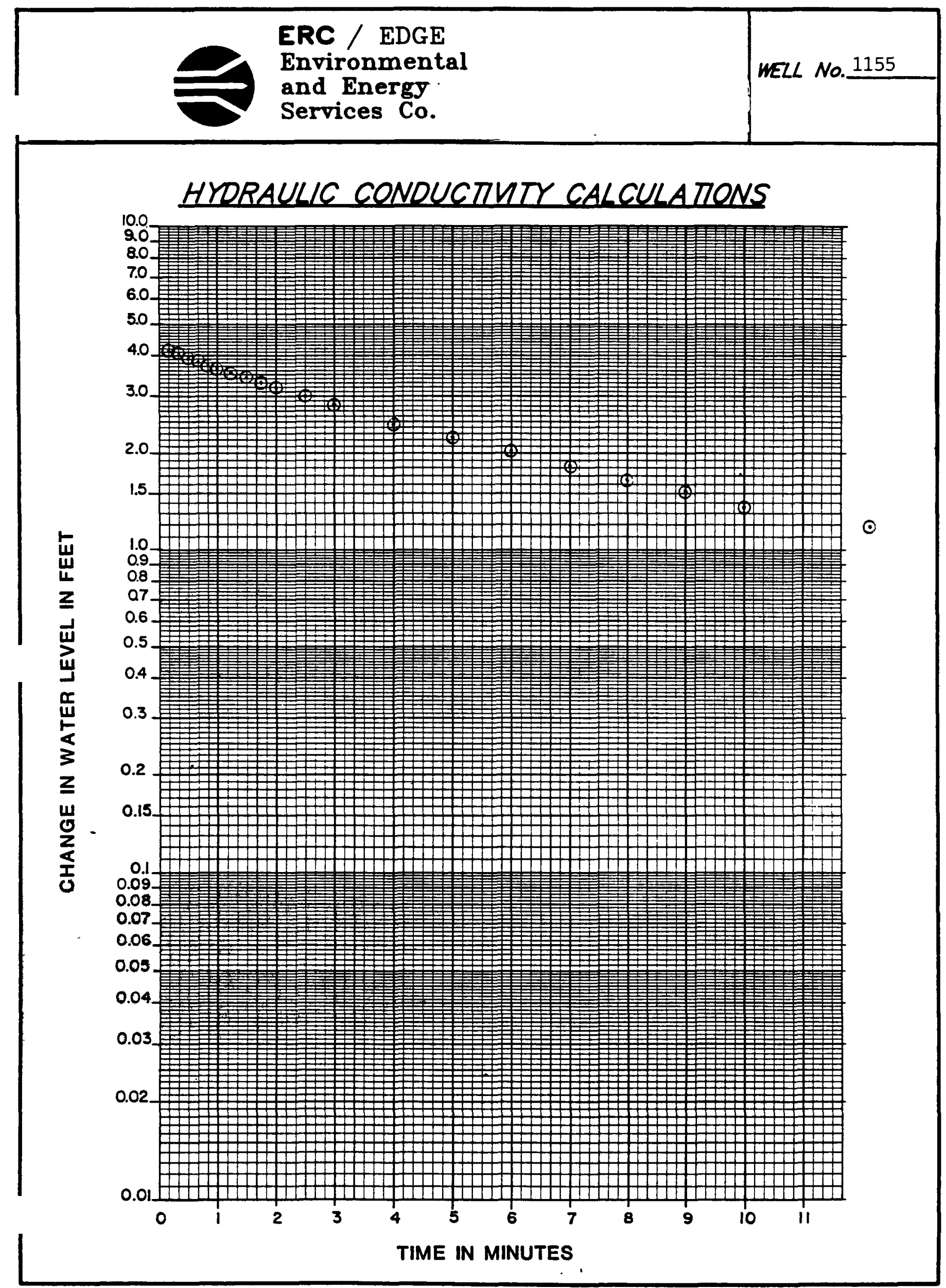

PACE 19 of 21 


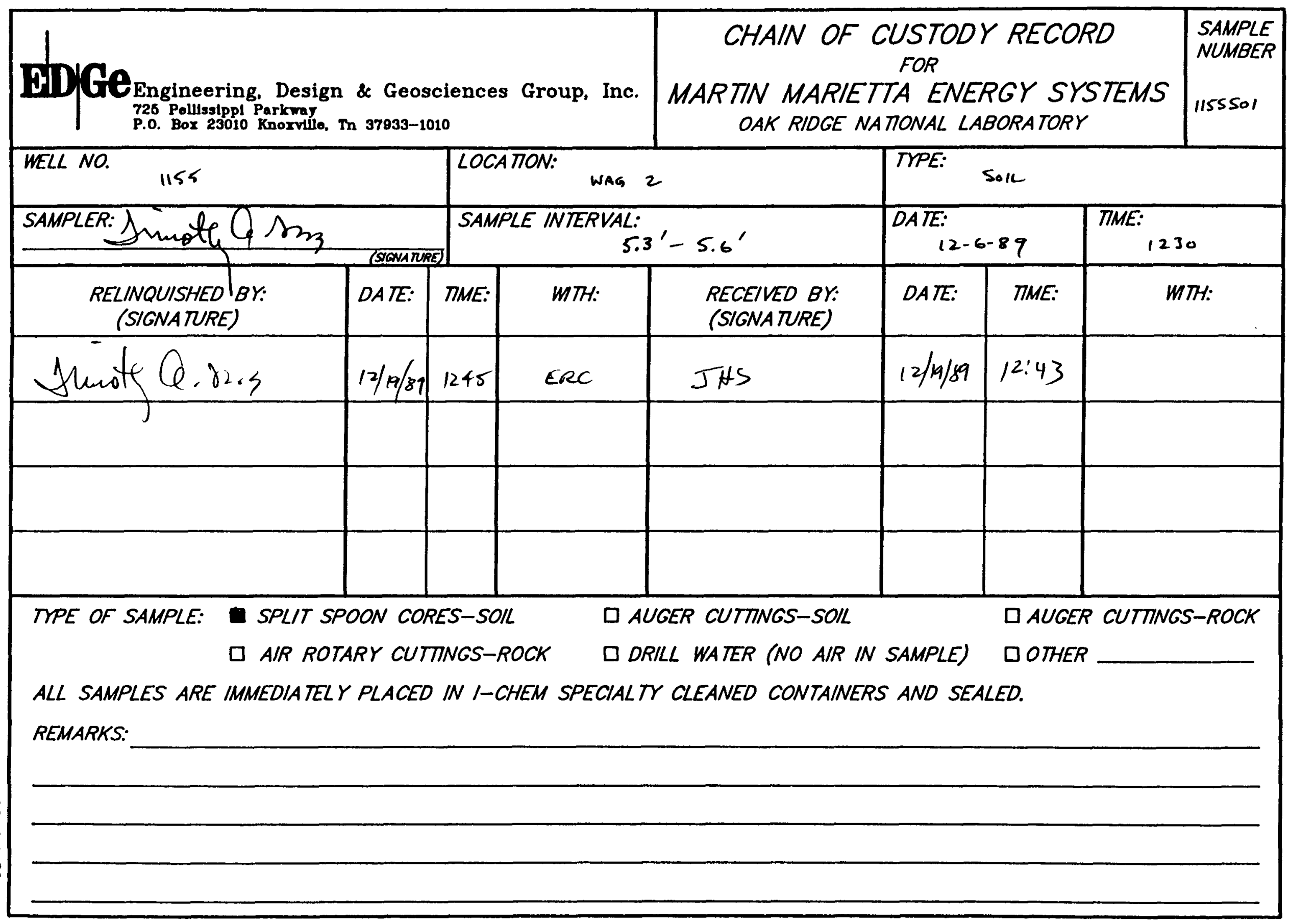




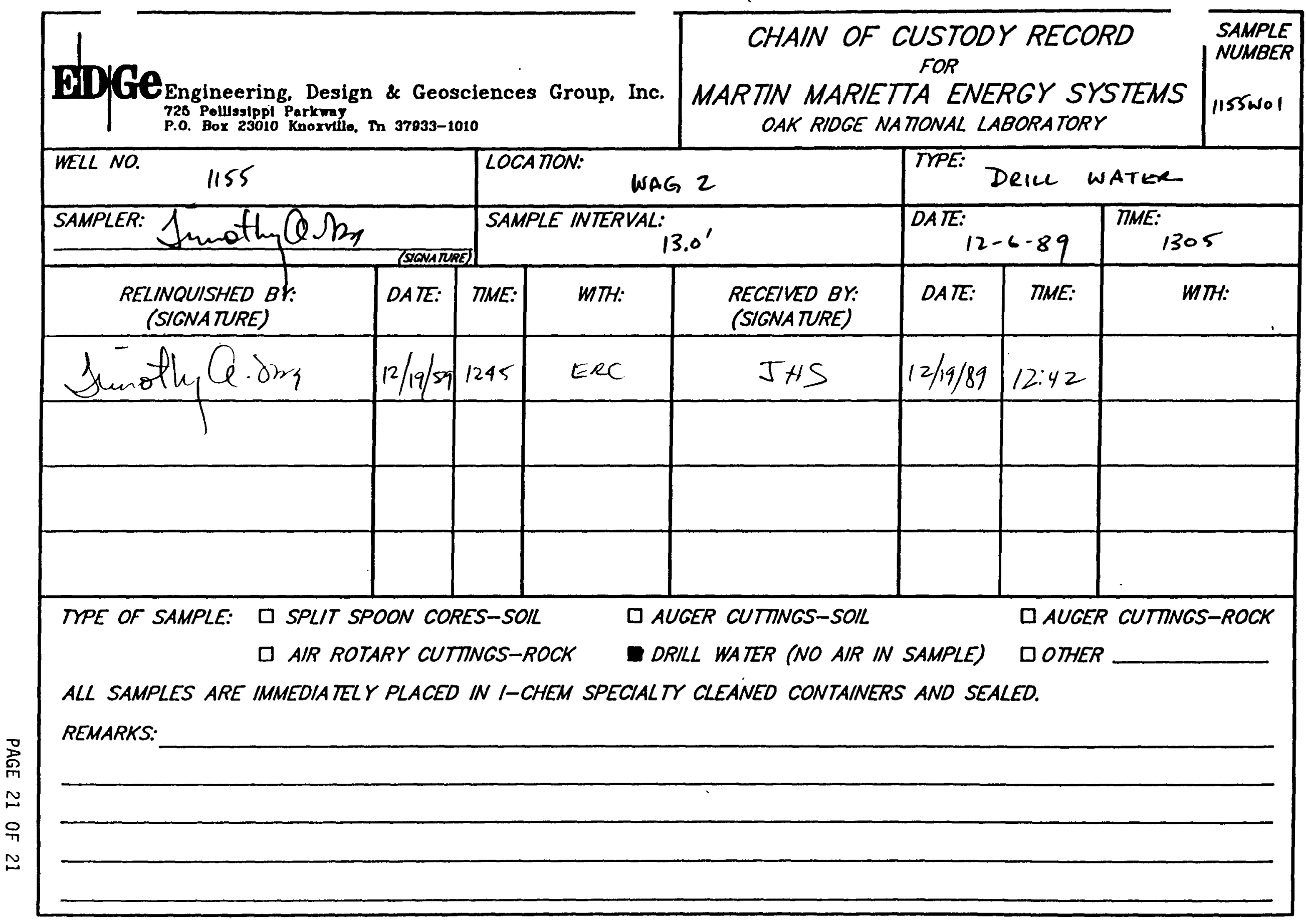




\subsection{General Information}

\subsection{Well Location}

Monitoring well number 1156 is located in Upper WAG 2 . It is in the southwestern corner of Upper WAG 2, approximately 200 feet north of the New Hydro-fracture facility. The location is shown on ORNL drawing number C3E20004A075. Survey coordinates for this well are $N$ $17,001.9312, \mathrm{E} 27,876.1244$ (X-10 grid) or latitude $35^{\circ}-$ $54^{\prime}-37.11^{\prime \prime}$ and longitude $84^{\circ}-18^{\prime}-58.85^{\prime \prime}$. Coordinate data were provided by Martin Marietta Energy Systems. The method used for conversion from $x-10$ grid to Tennessee-Lambert state Plane Coordinates came from the publication "Tennessee Valley Authority Data Services Branch and Mapping Services Branch, Oak Ridge, Tennessee, DOE Plant Control, November 6, 1985, Field Book: ESS-3115, pp. 1-20." The latitude and longitude were calculated by Adams Craft Herz Walker Engineering, Inc., using methods from the U.S. Coast and Geodetic Survey Publication 62-4, "state Plane coordinates by Automatic Data Processing."

\subsection{Drilling Information}

Well number 1156 was drilled by Geotek Engineering Company. A Schramm Rotadrill rig was used to drill this boring for monitor well installation under the operation of George Akins with the assistance of James Shelton. Drilling commenced on 12-12-89 and was finished on 12-12-89. Paragraph 2.4.1 includes a detailed discussion of the well installation and a well schematic is included on the well installation/ 
ERC / EDGE

Environmental

and Energy

Services Co.
MONITORING WELL PROGRAM

WEZL DATA NARRATVE WELL NO. 1156

completion form. A synopsis of the drilling activity

follows. This information was typed directly from field notes and was edited only when necessary for clarification.

12-12-89: The rig was mobilized to the staked location and set up on plastic sheeting. Split spoon samples were taken from the surface to 8.0 feet. The boring was deepened from 8.0 feet to refusal at 9.3 feet using a 6-inch auger. Water could be heard flowing into the well. Set 2-inch stainless steel screen and casing with sandpack and bentonite seal.

12-13-89: The casing was grouted into place with 1.0 sack of cement.

9-12-90: The protective casing, 2-inch stainless steel screen and riser were pulled in order to deepen the well.

9-13-90: The Ingersoll Rand T-4 drill rig and tools were steamcleaned.

9-14-90: The rig was mobilized to the well location and set up over $\$ 1156$. The boring was reamed from $0.0^{\prime}$ to 8.5 feet with 14-inch augers. Ten inch surface/diverter casing as set to 7.6 feet and grouted in place.

9-19-90: The Ingersoll Rand T-4 was decontaminated and mobilized to the location. Drilled from 7.6 to 21.4 feet with 8 -inch tricone bit. Ran in 2-inch stainless steel casing, screen, tremied sand and poured in bentonite. Grouted annulus to surface. 
ERC / EDGE

This well was logged by ERC Environmental and Energy Services Co., Inc., hydrogeologist Timothy A. Lee. All well construction materials and supplies were from Martin Marietta Energy Systems approved batches. The batch origin of individual items is shown on the included Monitoring Well Materials Certification form.

\subsection{Teobnical Information}

\subsection{Decontamination Procedures}

The drilling rig, down hole tools, surface casing, stainless steel screen, stainless steel casing, centralizers, and stainless steel silt trap underwent the cleaning decontamination procedures outlined in the drilling specifications (Release Specific Technical Directions for Regulatory Compliance Monitoring Wells Phase 1, Oak Ridge National Laboratory, Oak Ridge, w.O. K-4147, April 1987, pgs. 2-4). A checklist of the cleaned materials is included with this data package.

\subsection{Geology}

The Rome Formation underlies the northern portion of Upper WAG 2 and consists of variegated shale and -iltstone with beds of gray, fine grained sandstone. The Conasauga Group underlies the southern portion of Upper WAG 2 and is divided into five members. They are from north to south, the Pumpkin Valley Shale, Rutledge Limestone, Rogersville Shale, Maryville Limestone, and Nolichucky Shale. These rocks have undergone extensive deformation and contain many folds and faults resulting in varying strike and dips. The regional strike is 56 


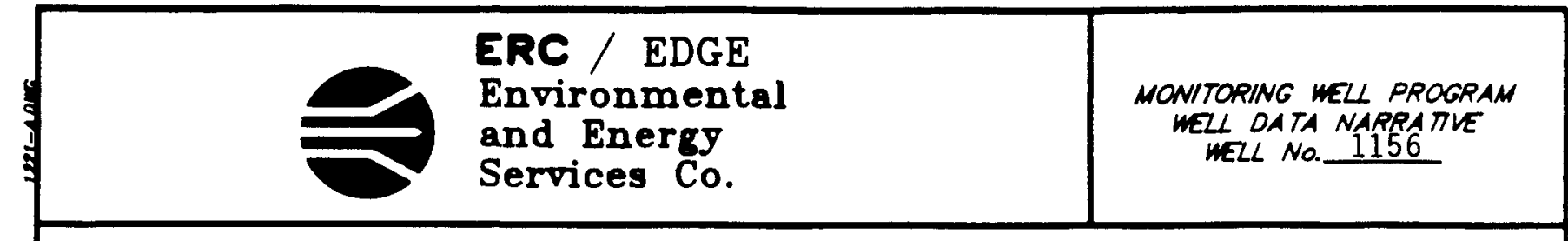

degrees northeast with dips of about 30 degrees to the southeast. The white oak Creek tear fault is in Upper WAG 2. Displacement varies from 40 feet up to 350 feet.

\subsection{Bample collection}

One soil sample was collected during drilling, placed in an I-CHEM specialty cleaned glass container, sealed and submitted to Sample Receiving, Analytical Chemistry Division, Bldg. 4500S, ORNL. A chain of custody form for this soil sample is included with this data package. Soil sample 1156501 was collected in the split spoon interval from 4.3 ' to 4.8 ' on $12-12-89$.

A bulk density soil sample was collected from the split spoon sample interval from $2.5^{\prime}$ to $2.8^{\prime}$. The sample was measured and weighed, and a bulk density of 2.17 grams $/ \mathrm{cm}^{3}$ was calculated.

\subsection{Installation and Development}

\subsubsection{Installation}

This was a Type $D$ well. The air rotary method was required to complete the boring to the specified total well depth. A 14-inch diameter boring was augered from ground surface to 7.6 feet and 10-inch diverter casing was installed and grouted. An 8-inch diameter boring was then drilled with an air rotary tricone roller bit from 8.5 to 21.4 feet. A 2-inch diameter stainless steel screen with threaded botton cap was installed from 11.0 to 21.3 feet. A 2-inch diameter stainless 
steel casing was installed above the screen at 11.0 feet and extended 2.07 feet above ground surface. A sandpack was then tremied into the annular space from 8.3 to 21.3 feet, with a bentonite pellet seal poured into the annular space above the sandpack from 7.3 to 8.3 feet.

The annular space from the top of the bentonite seal to the surface was tremie-grouted with a cement/bentonite slurry. A detail of the well is included on the well installation/completion form.

\subsubsection{Well Development}

Well number 1156 was developed to remove drill cuttings, silt, and other fines. The monitoring well was developed using a Geoguard pump with an air compressor. All pumps were cleaned prior to use according to specified cleaning procedures (see Paragraph 2.1). The well was developed until a measured total of 120 gallons of water had been evacuated and the clarity of the discharge water was approved by the company representative. The final turbidity value measured at completion was 2.0 NTU's. A development form showing the exact method of development and other pertinent data is appended.

2.4 .3

Installation of Dedicated Monitoring well Pump

After the well was developed, a Geoguard Model No. 5614 dedicated monitoring well pump was installed on 10/8/90 at a depth of 20.1 feet below ground surface. These 
ERC / EDGE

Environmental

and Energy

Services Co.
NONITORING WELL PROGRAM

WEZL DATA NARRATVE

WELL NO. 1156

pumps are decontaminated at American sigma and are sent prepackaged. A copy of the pump certification is kept on file at ORNL.

\subsection{Hydraulie conductivity Testing}

Well number 1156 was tested for the determination of hydraulic conductivity of the aquifer in the vicinity of the well screen. This was accomplished by instantaneously adding a known quantity of water to the monitoring well and measuring the recovery of the water level over time. The changing water levels were measured using a Druck $15 \mathrm{psi}$ pressure transducer and an Omnidata Datapod II data recorder. The hydraulic conductivity value of $4.22 \times 10^{-5} \mathrm{~cm} /$ second (shown as permeability on the hydraulic conductivity calculations printout attached) was calculated using the Bouwer and Rice method. A computer printout of the hydraulic conductivity calculations is included in this data package. 
ERC / EDGE

Environmental

and Enerey

Services Co.

\section{PRE-DRILLING CHECKLIST FOR MONITORING WELLS}

RRE-DRILUNG TASKS

1. EXCAVTION PERMIT OBTAINED

2. ALL EQUIPMENT HAS BEEN CLEANED BEFORE DRILLING.

30. SCREEN AND CASING HAVE BEEN WASHED, STEAMED, RINSED WTH DE-IONIZED OR DISTLLED WATER, RINSED WTH ISOPROPV ALCOHOL, WRAPPED WTH PROTECTVE COVERING AND STORED OFF THE GROUND.

36. PRE-PACKAGED SCREENS, CASING AND CENTRALUZERS WERE USED.

4. WORK AREA FOR SAMPLE EXAMINATON COVERED WTH CLEAN POL YETHIENE.

5. CLEAN KNIVES, GLOVES, SAMPLE JARS AND LABELS ON HAND.

6. POL YETHRENE COVER IN PLACE OVER HOLE.

7. AIR ROTARY COMPRESSED AIR SAMPLED.

RESULTS: $\mathrm{N} / \mathrm{A}$

\section{COMPLIANCE}

DATE

12-12-89 T+3

$12-12-89$

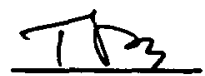

$\mathrm{N} / \mathrm{A}$

$\mathrm{N} / \mathrm{A}$

12-12-89

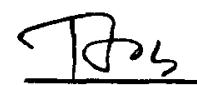

12-12-89 Tr3

$12-12-89$

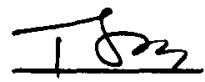

$12-12-89$

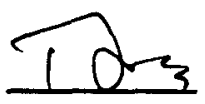

$\mathrm{N} / \mathrm{A}$

$\mathrm{N} / \mathrm{A}$

ADOIMONAL NOTES/OBSERVATONS:

OBSERVER SIGNATURE/DATE

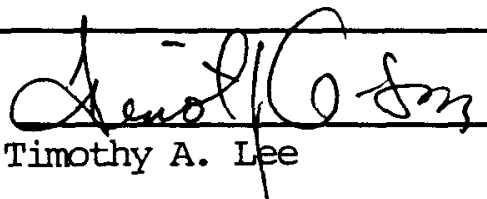

$12-12-89$

Timothy A. Lee

PAGE 7 = of 21 


\section{PRE-DRILLING CHECKLIST FOR MONITORING WELLS}

PRE-DRIILING IASKS

1. EXCAVTION PERMIT OBTAINED

2. ALL EOUIPMENT HAS BEEN CLEANED BEFORE ORILLNG.

30. SCREEN AND CASING HAVE BEEN WASHED, STEAMED, RINSED WTH DE-IONIZED OR DISTLLED WATER, RINSED WTH ISOPROPN ALCOHOL WRAPPED WTH PROTECTVE COVERING AND STORED OFF THE GROUND.

36. PRE-PACKAGED SCREENS, CASING AND CENTRALIZERS WERE USED.

4. WORK AREA FOR SAMPLE EXAMINATION COVERED WTH CLEAN POL YETHRENE.

5. CLEAN KNIVES, GLVES, SAMPLE JARS AND LABELS ON HAND.

6. POL YETHRENE COVER IN PLACE OVER HOLE.

7. ANR ROTARY COMPRESSED AIR SAMPLED.
COMPLANCE

DAIE

$9-14-90$

INIRALS

$9-14-90$

N/A

N/A

9-20-90

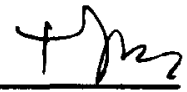

9-14-90

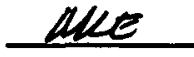

$9-14-90$

ME

$9-14-90$

Ne

N/A

N/A

RESUL TS:

ADDITIONAL NOTES/OBSERVATIONS:

\section{ADOIMONAL NOTES/OBSERVATIONS.}




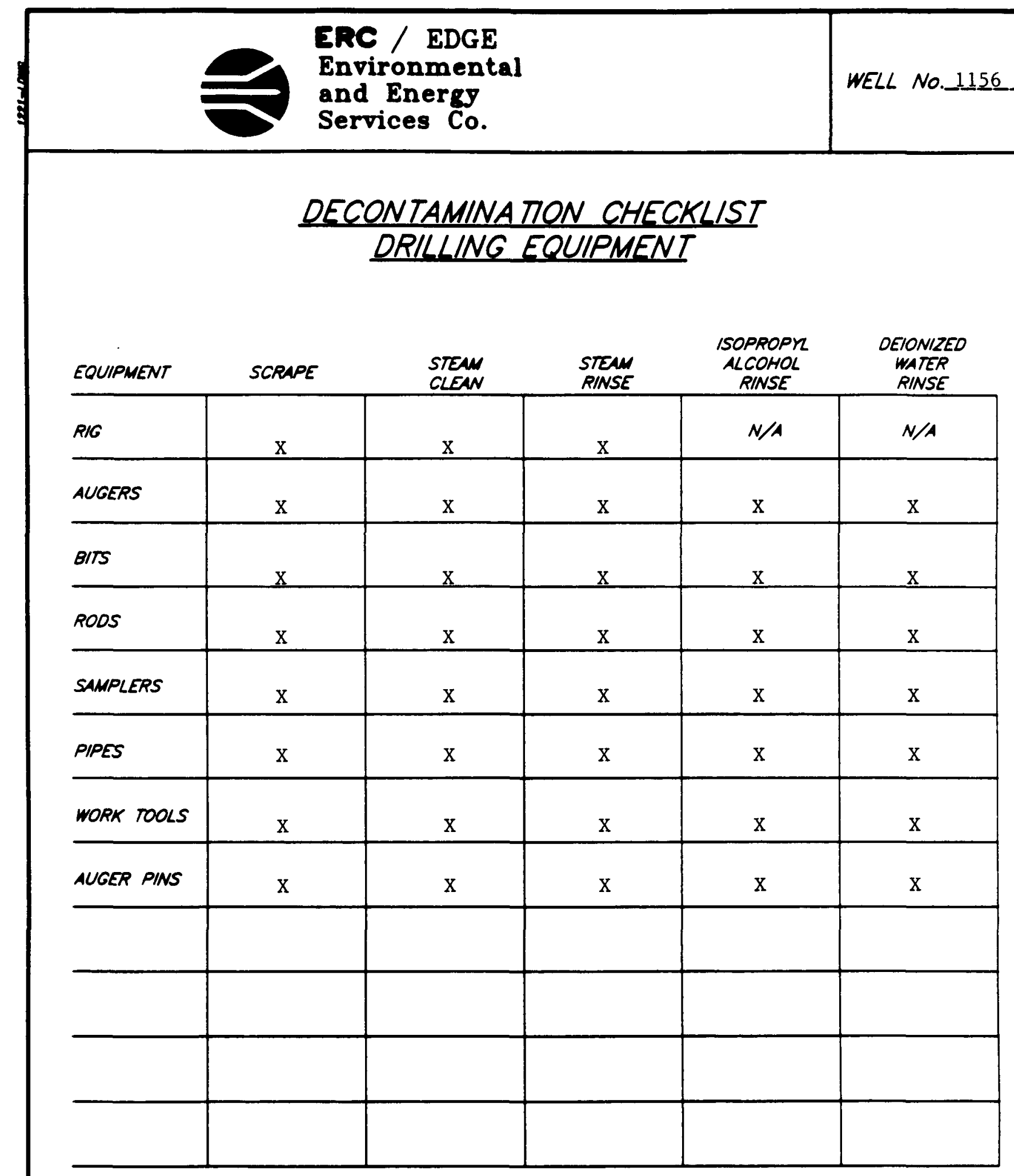

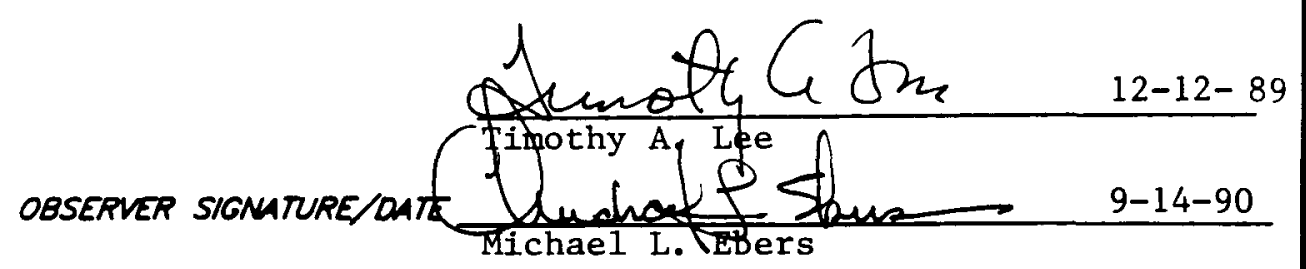

PAGE 9 OF 21. 
ORNL MONITORING WELL LOG

LOCA nON: Upper WAG 2

ORILLER: George Akins \& Larry Ledbetter

HELPER: James Shelton \& Fred Dixon

ORKL: Schramm Rotadrill \& Ingersol1 Rand

TPE DRIUNG: Split spoon, auger, air rotary

No. SAMPLES TAKEN:

One

CONTANWENT TrPE: Plastic, pan, containment box

THICKNESS OF SOL (RETUSAL DEPTH): $9.3^{\prime}$

OEPTH DRLLED IN ROCK:

$12.1^{\prime}$

TOTAL OEPTH OF MELL:

\section{PAG 1 or 2}

DATE: START: $12-12-89$

FINISH: $\frac{9-20-90}{1}$

LOCGED Br. Timothy A. Lee \& Michael

L. Ebers

HEALTH PHRSCAST: Bill Shinpaugh \& Carl Stooksbury

LUBRICANT TYPE: Green stuff

IPPE: Soil

\begin{tabular}{|c|c|c|c|c|}
\hline \multicolumn{2}{|c|}{$\begin{array}{l}\text { OEPTH } \\
\text { (FEET) }\end{array}$} & $\begin{array}{c}\text { SAMPEL } \\
\text { (NUMBER A } \\
\text { INTERVAL) }\end{array}$ & $\begin{array}{c}\text { PERCENT } \\
\text { RECONERY } \\
\text { (SPUT SPOONS) }\end{array}$ & SOK/BEDPOCK DESCRIPTION \\
\hline 0.0 & 2.0 & & Augered & Gravel fill \\
\hline \multirow[t]{4}{*}{2.0} & 4.0 & & $75 \%$ & Clay, dark yellowish orange, medium dense, wet \\
\hline & & & & plastic; mottled with clay, yellowish gray; \\
\hline & & $\bullet$ & & dark streaks, Bulk density taken 2.5 to $2.8^{\prime}$ \\
\hline & & & & $=2.17 \mathrm{~g} / \mathrm{cm}^{3}$ \\
\hline \multirow[t]{4}{*}{4.0} & 6.0 & $1156 \mathrm{SO} 1$ & $85 \%$ & Clay, dark yellowish orange, wet, plastic, \\
\hline & & $4.3^{\prime}$ to $4.8^{\prime}$ & & mottled with clay, yellowish gray, dark \\
\hline & & & & streaks; vegetation roots. Scattered cavities \\
\hline & & & & throughout \\
\hline \multirow[t]{2}{*}{6.0} & 6.5 & & $60 \%$ & Clay, dark yellowish orange, moist, dense, \\
\hline & & & & mottled with clay, yellowish gray; dark streaks \\
\hline 6.5 & 6.7 & & $60 \%$ & Cavity, wet \\
\hline \multirow[t]{4}{*}{6.7} & 8.0 & & $60 \%$ & Clay, dark yellowish orange, moist, dense; \\
\hline & & & & mottled with clay, yellowish gray; dark \\
\hline & & & & streaks; roots \\
\hline & 8.0 & & & Split spoon refusal \\
\hline 8.0 & 9.3 & & Augered & Shale, limey, medium hard \\
\hline 9.3 & 12.0 & & & *Shale, hard \\
\hline 12.0 & 13.0 & & & Limestone, very hard \\
\hline 13.0 & 21.4 & & & Shale, hard \\
\hline & & & & \\
\hline
\end{tabular}




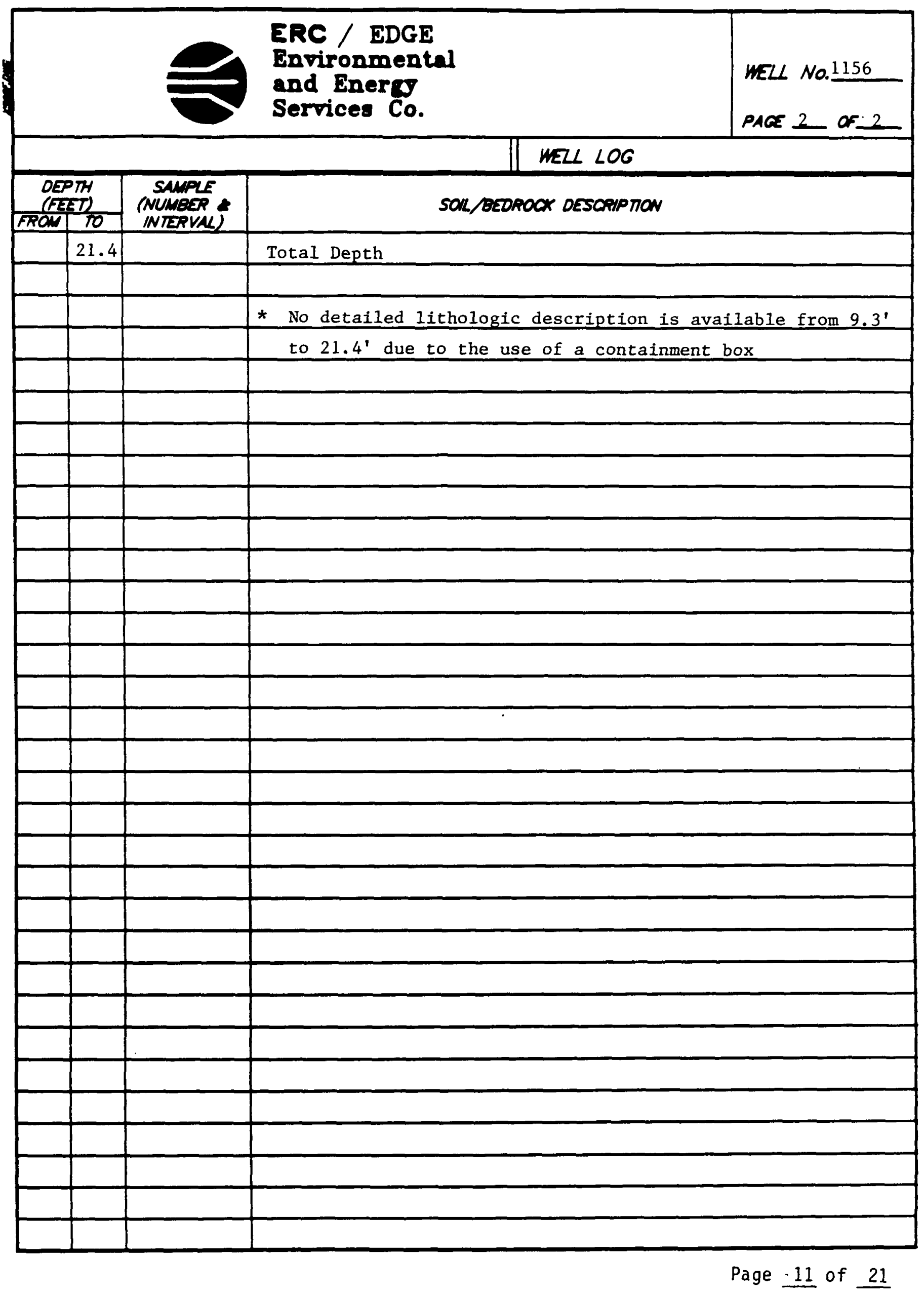




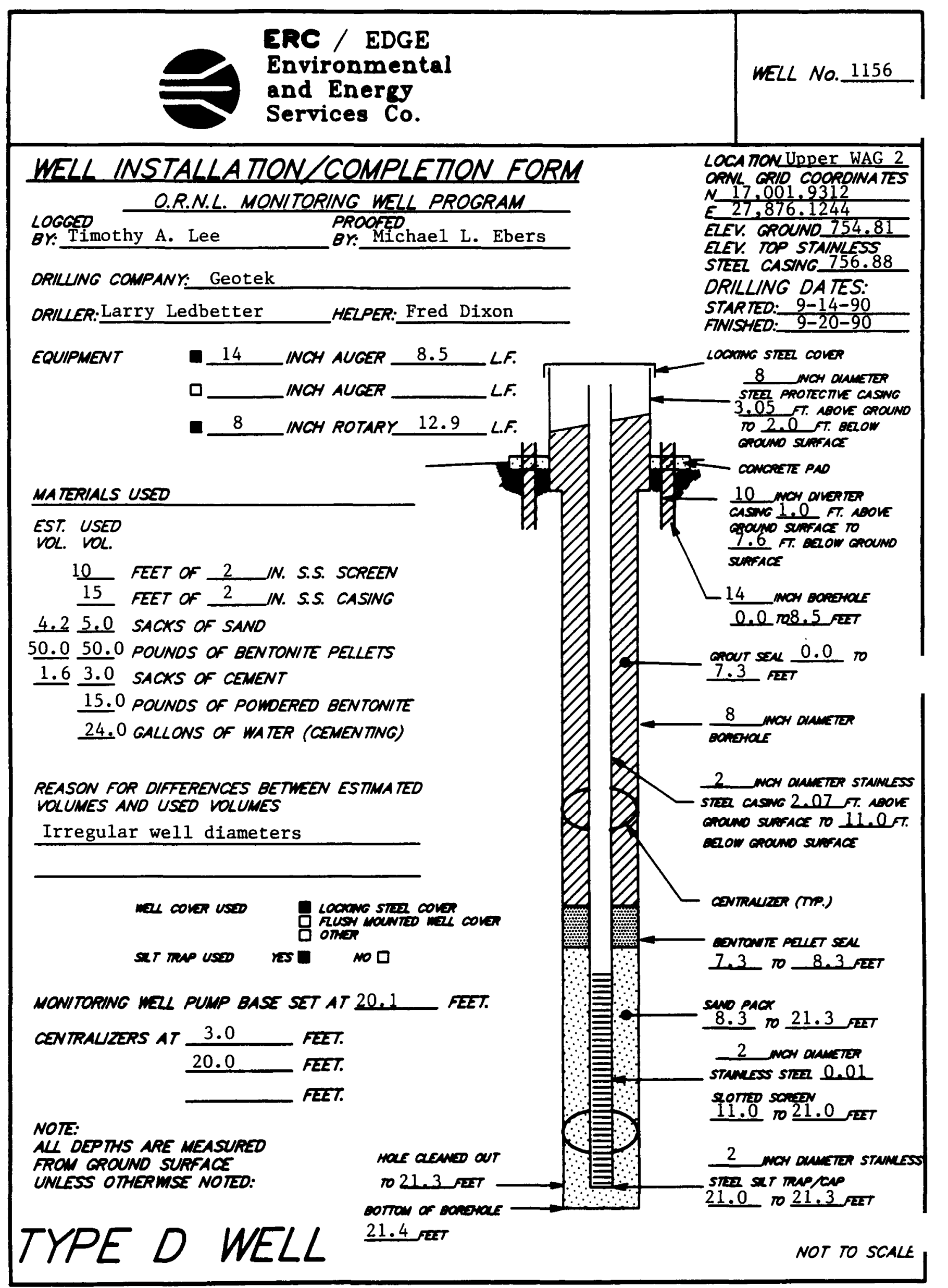


ERC / EDGE

Environmental

MELL NO._1156

and Energy

Services Co.

DA TE: $9-20-90$

\section{MONITORING WELL MATERIALS \\ CERTIFICATION}

ITEM/MA TERIAL

\begin{tabular}{|c|c|c|}
\hline & RATE USED & BATCH NUAMER \\
\hline & $9-20-90$ & 2 \\
\hline \multirow{2}{*}{$\begin{array}{l}\text { Pellet } \\
\text { Powder }\end{array}$} & $9-20-90$ & 6 \\
\hline & $9-20-90$ & 1 \\
\hline \multirow{2}{*}{ 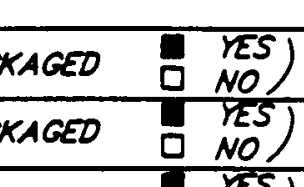 } & $9-20-90$ & 4 \\
\hline & $9-20-90$ & 4 \\
\hline 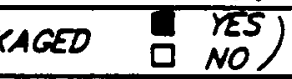 & $9-20-90$ & 4 \\
\hline \multirow{3}{*}{ 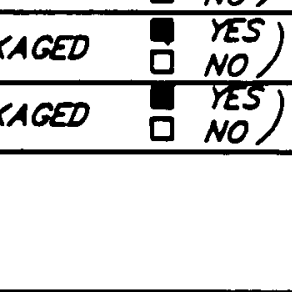 } & $9-20-90$ & 4 \\
\hline & $10-8-90$ & 8 \\
\hline & $9-20-90$ & 7 \\
\hline & $\mathrm{N} / \mathrm{A}$ & $\mathrm{N} / \mathrm{A}$ \\
\hline
\end{tabular}

COMMENTS:

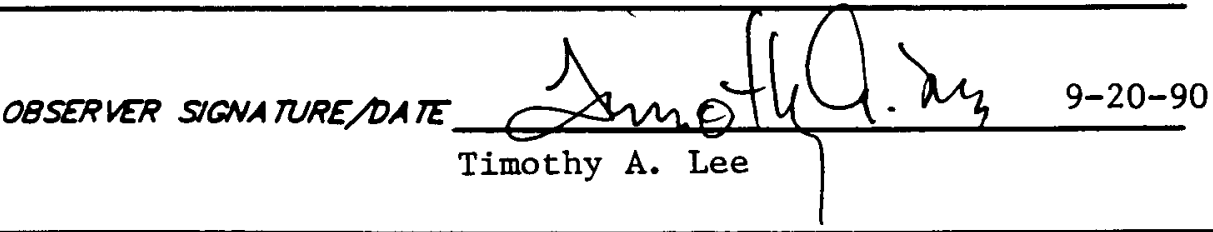

PAGE 13 OF 21 


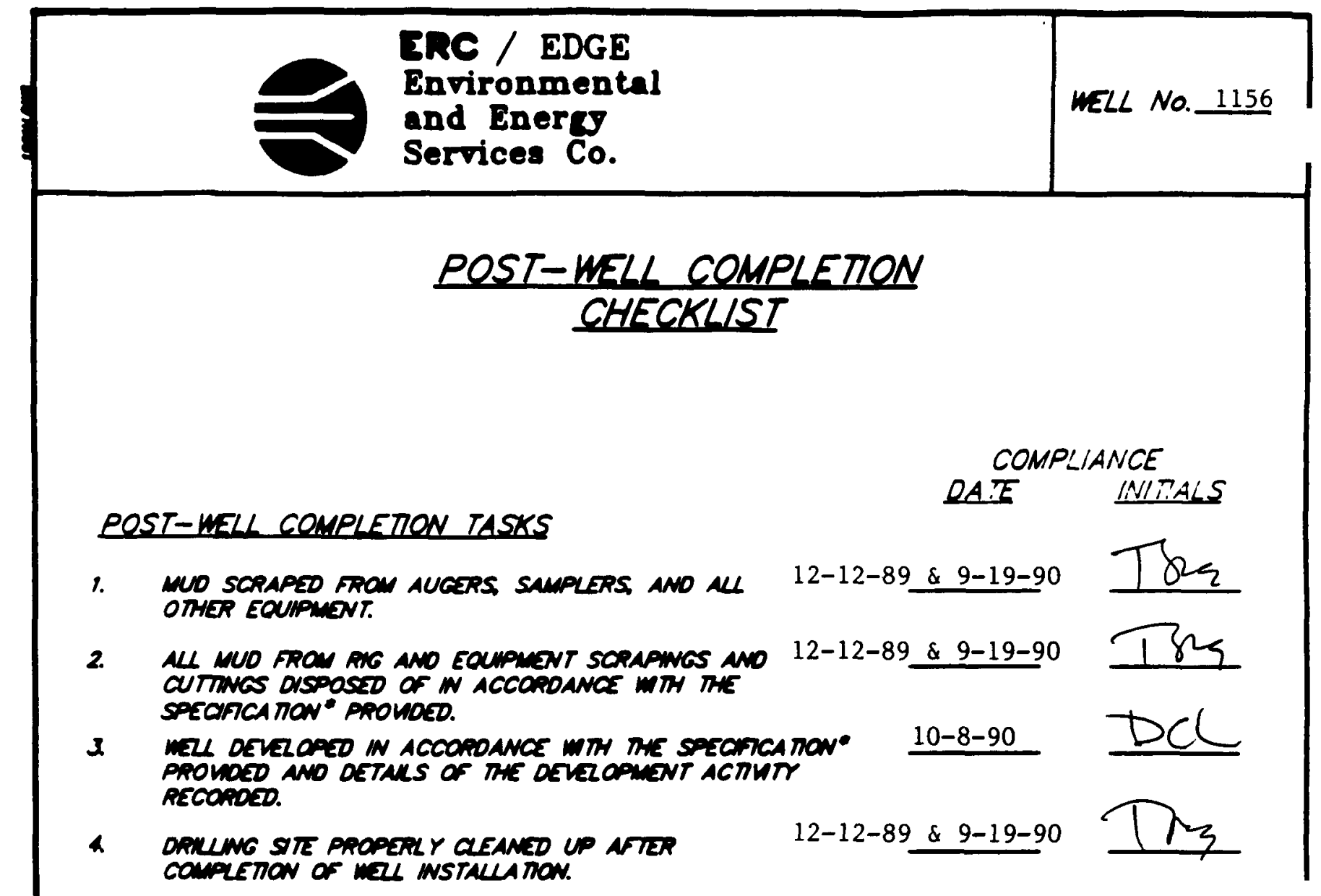

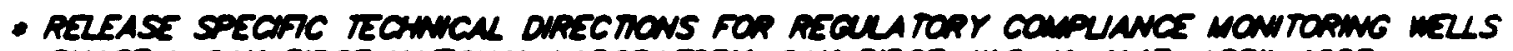

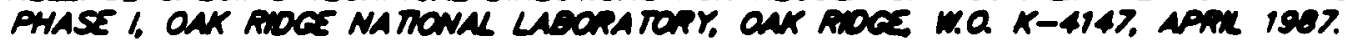

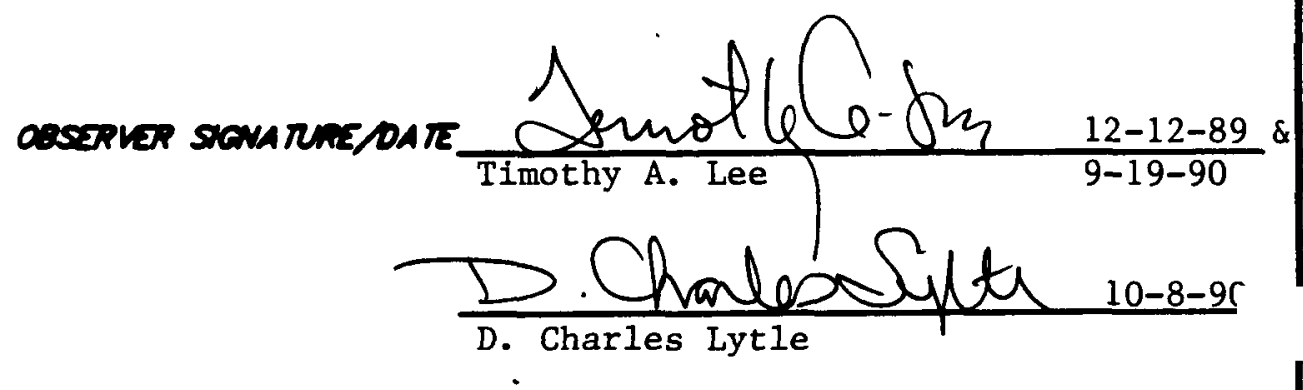




\section{MONITORING WELL \\ DEVELOPMENT FORM}

DEVELOPMENT DETAILS

METHOD OF

QEVELOPMENT: Surging and pumping

DEVELOPMENT

BEGAN DATE: $\quad 9-24-90$ TME:

DEVELOPMENT

ENDING DATE: $\quad 10-8-90$

DEVELOPNENT

OBSERVEO BY: D. Charles Lytle

ONE WELL VOLUME: 6.9 GALLONS

TOTAL GALLONS PUMPED: 120 TOTAL WEL VOLUMES PUMPED: 17.4

INITIAL PH: 9.4

FNAL PH: 7.8

INITAL CONOUCTUTH (KS/Cm): 578 FNAL CONOUCTUTH ( $\mu S / \mathrm{cm}): 810$

OESCRIPTON OF INITAL TURBIOITY: Slightly cloudy

OESCRIPTION OF FNAL RURBIDITY. Clear

FNAL NEASURED TURBIOITY: 2.0 NTU'S

WEL APPROVED BY: R.C. Williams MMES

ODOR

QE MAIER: None

WATER O GROUND SURFACE

OISCHARGED I STORW SEWERS

TO: $\square$ DRUNS

口 TANK RUCK

I STORAGE TANKS

口 OTHER

WITAL PRE-DEVEOONENT

WATRP DEPTH: 7.9 feet from ground surface

\section{DEVELOPMENT OBSERVATIONS}

Re-drill because well was not producing sufficient water. Deepened hole to 21.4 feet.

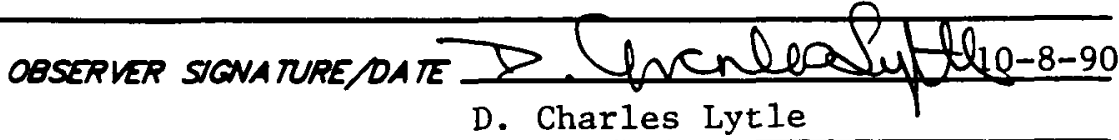




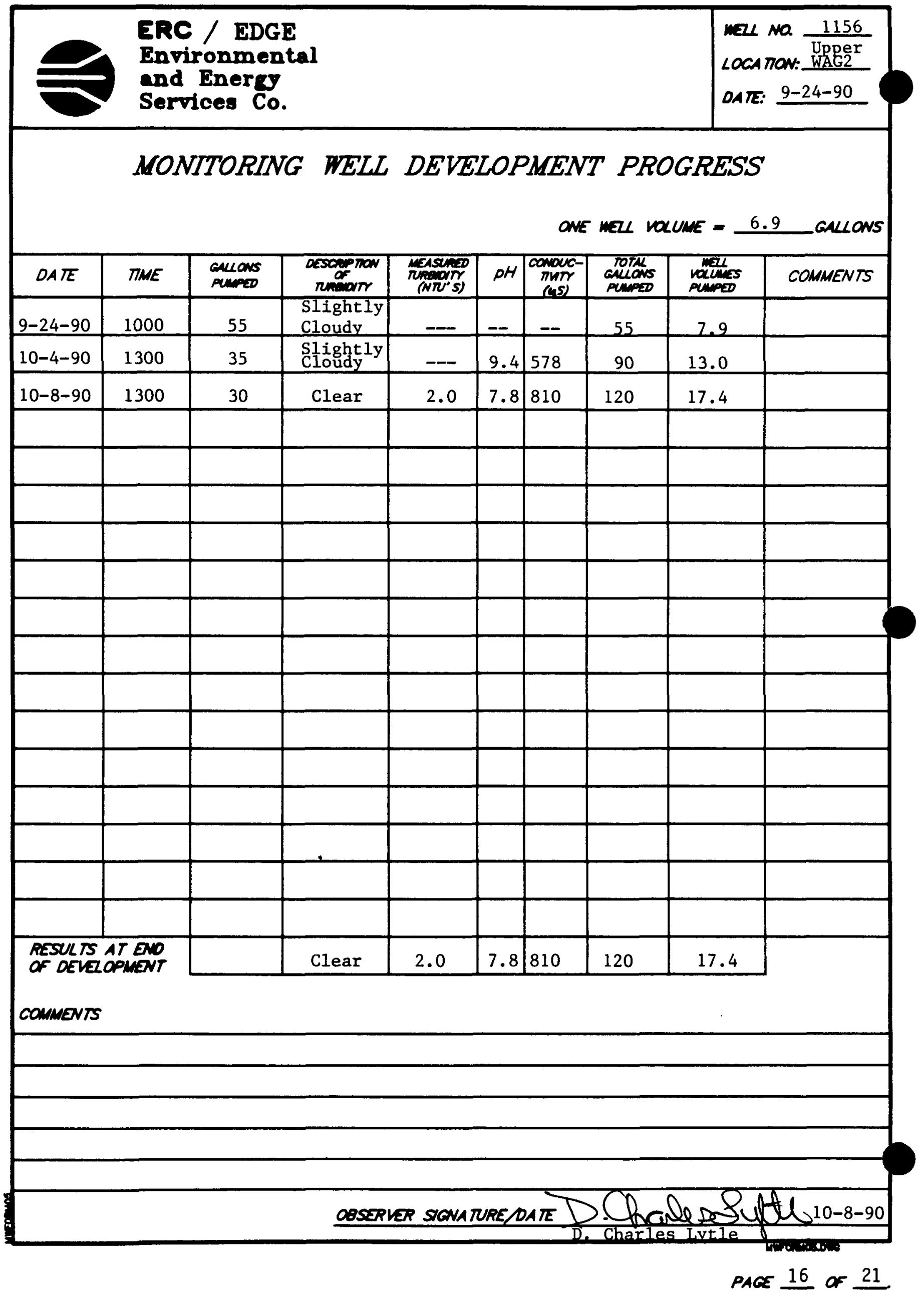




\section{HYDRAULIC CONDUCTIVTY CALCULATIONS}

PROGRAM SLUGT, VERSION 4.1, NOV. 1986

THIS PROGRAM CALCULATES MEAN TRANSMISSIVITIES FROM SLUG-TEST DATA BASED ON TWO ANALYTICAL APPROACHES:

(1) METHOD OF COOPER, BREDEHOEFT AND PAPADOPULOS, 1967 (ARTICLE IN VOL.3, NO.I OF WRR ENTITLED "RESPONSE OF A FINITE DIAMETER WELL TO AN INSTANTANEOUS CHARGE OF WATER")

(2) METHOD OF BOUWER AND RICE, 1976 (ARTICLE IN VOL. 12 , N0.3 OF WRR ENTITLED

"A SLUG TEST FOR DETERMINING HYDRAULIC CONDUCTIVITY OF UNCONFINED AQUIFERS WITH COMPLETELY OR PARTIALLY PENETRATING WELLS")

WELL NO.: 1156

PROJECT NO.: E221-002

SITE LOCATION: U. WAG-2

:DGE, INC. FIELD INVESTIGATOR: JAMES W. CARUTHERS

INPUT DATA ARE:

INNER CASING DIAMETER $=2.00$ INCHES

INNER SCREEN OR OPEN-HOLE DIAMETER $=2.00$ INCHES

DIAMETER OF DRILLED HOLE $=8.00$ INCHES

LENGTH OF SCREEN OR INTAKE PORTION $=10.00$ FEET

DEPTH FROM STATIC LEVEL TO BOTTOM OF SCREEN $=15.85$ FEET

THICKNESS OF SATURATED AQUIFER ZONE $=10.00 \mathrm{FEET}$

DEPTH TO STATIC WATER LEVEL BELOW REF. POINT $=1.00$ FEET

ESTIMATED POROSITY OF GRAVEL PACK $=.20$

FALLING-HEAD INDEX $=1$ ("I" IF FALLING, "0" IF RISING)

NUMBER OF DEPTH-TIME DATA POINTS = 32

HO WAS COMPUTED FROM INTERCEPT OF PLOT OF LOG(H) VS. TIME

SUCCESSIVE COMPUTED

VALUES FOR HO

(FEET)

1.2228

1.2640 


\section{HYDRAULIC CONDUCTIVTY CALCULATIONS}

\begin{tabular}{|c|c|c|}
\hline$\left(\operatorname{SEC}^{\text {TIME }}\right)$ & $\begin{array}{l}\text { DEPTH TO WATER } \\
\text { (FEET) }\end{array}$ & $\begin{array}{l}\text { HEAD } \\
(\text { FEET) }\end{array}$ \\
\hline $\begin{array}{r}10.00 \\
20.00 \\
30.00 \\
40.00 \\
50.00 \\
60.00 \\
75.00 \\
90.00 \\
105.00 \\
120.00 \\
150.00 \\
180.00 \\
240.00 \\
300.00 \\
360.00 \\
420.00 \\
480.00\end{array}$ & $\begin{array}{l}4.850 \\
4.230 \\
3.800 \\
3.410 \\
3.100 \\
2.890 \\
2.580 \\
2.360 \\
2.190 \\
2.040 \\
1.860 \\
1.700 \\
1.530 \\
1.460 \\
1.390 \\
1.360 \\
1.340\end{array}$ & $\begin{array}{r}3.850 \\
3.230 \\
2.800 \\
2.410 \\
2.100 \\
1.890 \\
1.580 \\
1.360 \\
1.190 \\
1.040 \\
.860 \\
.700 \\
.530 \\
.460 \\
.390 \\
.360 \\
.340\end{array}$ \\
\hline $\begin{array}{r}540.00 \\
600.00 \\
720.00 \\
840.00 \\
960.00 \\
1080.00 \\
1200.00 \\
1320.00 \\
1440.00 \\
1560.00 \\
1680.00 \\
1800.00 \\
1920.00 \\
2040.00 \\
2160.00\end{array}$ & $\begin{array}{l}1.310 \\
1.260 \\
1.240 \\
1.230 \\
1.190 \\
1.180 \\
1.180 \\
1.180 \\
1.170 \\
1.170 \\
1.170 \\
1.150 \\
1.150 \\
1.150 \\
1.150\end{array}$ & $\begin{array}{l}.310 \\
.260 \\
.240 \\
.230 \\
.190 \\
.180 \\
.180 \\
.180 \\
.170 \\
.170 \\
.170 \\
.150 \\
.150 \\
.150 \\
.150\end{array}$ \\
\hline
\end{tabular}




\section{HYDRAULIC CONDUCTIVTY CALCULATIONS}

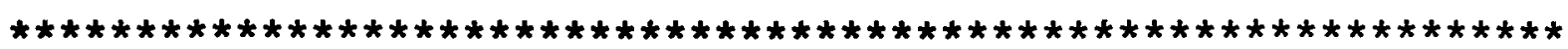

METHOD OF BOUWER AND RICE

COMPUTED RESULTS USING DIAMETER OF DRILLED HOLE:

PERMEABILITY $=1.38 \mathrm{E}-06 \mathrm{FT} / \mathrm{SEC}=4.22 \mathrm{E}-05 \mathrm{CM} / \mathrm{SEC}$

TRANSMISSIVITY $=1.38 \mathrm{E}-05 \mathrm{FT} * 2 / \mathrm{SEC}$

COMPUTED RESULTS USING DIAMETER OF CASING AND SCREEN:

PERMEABILITY $=1.95 \mathrm{E}-06 \mathrm{FT} / \mathrm{SEC}=5.95 \mathrm{E}-05 \mathrm{CM} / \mathrm{SEC}$

TRANSMISSIVITY $=1.95 \mathrm{E}-05 \quad \mathrm{FT} * * 2 / \mathrm{SEC}$ 


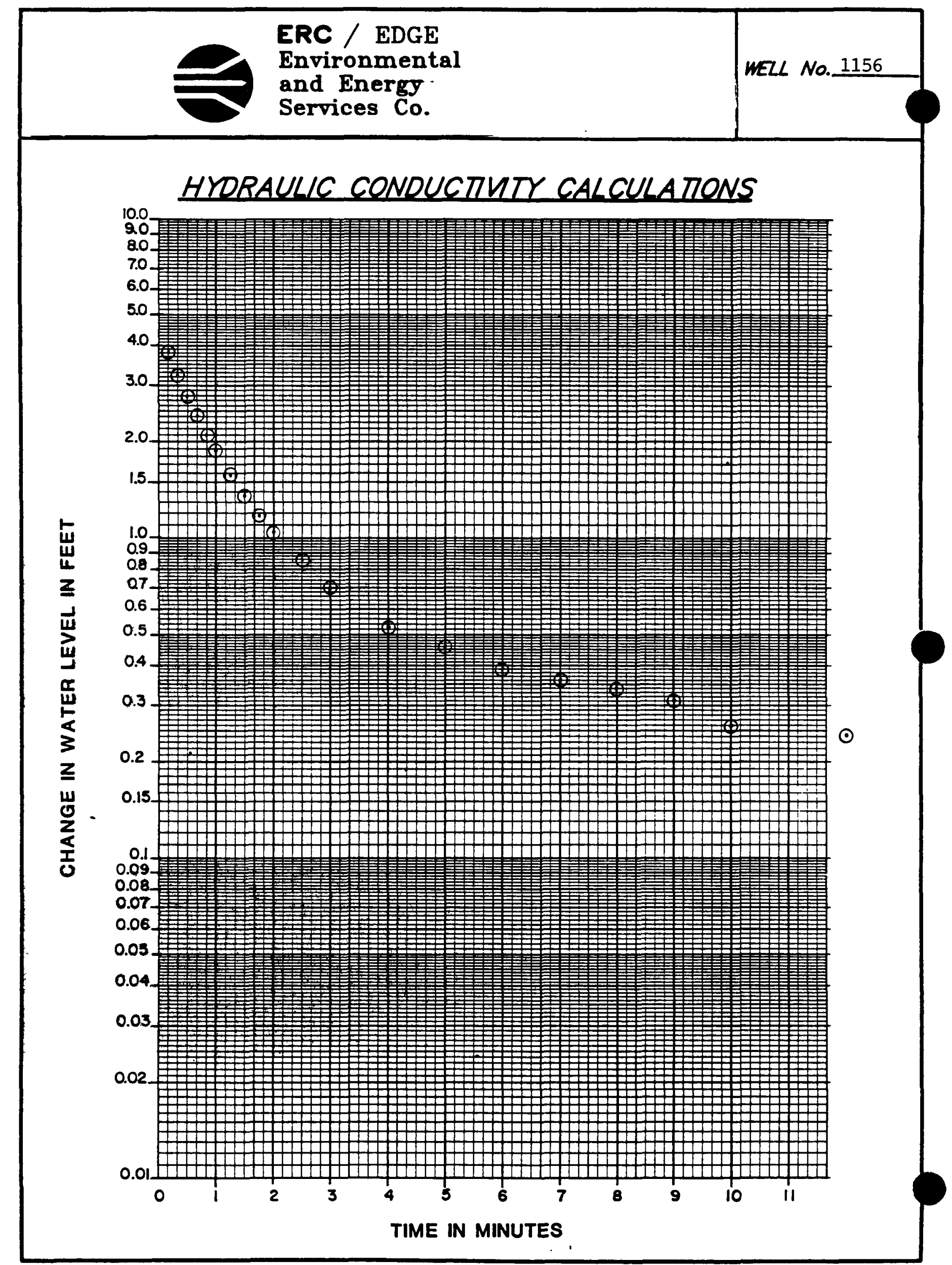

PACE 20 of 21 


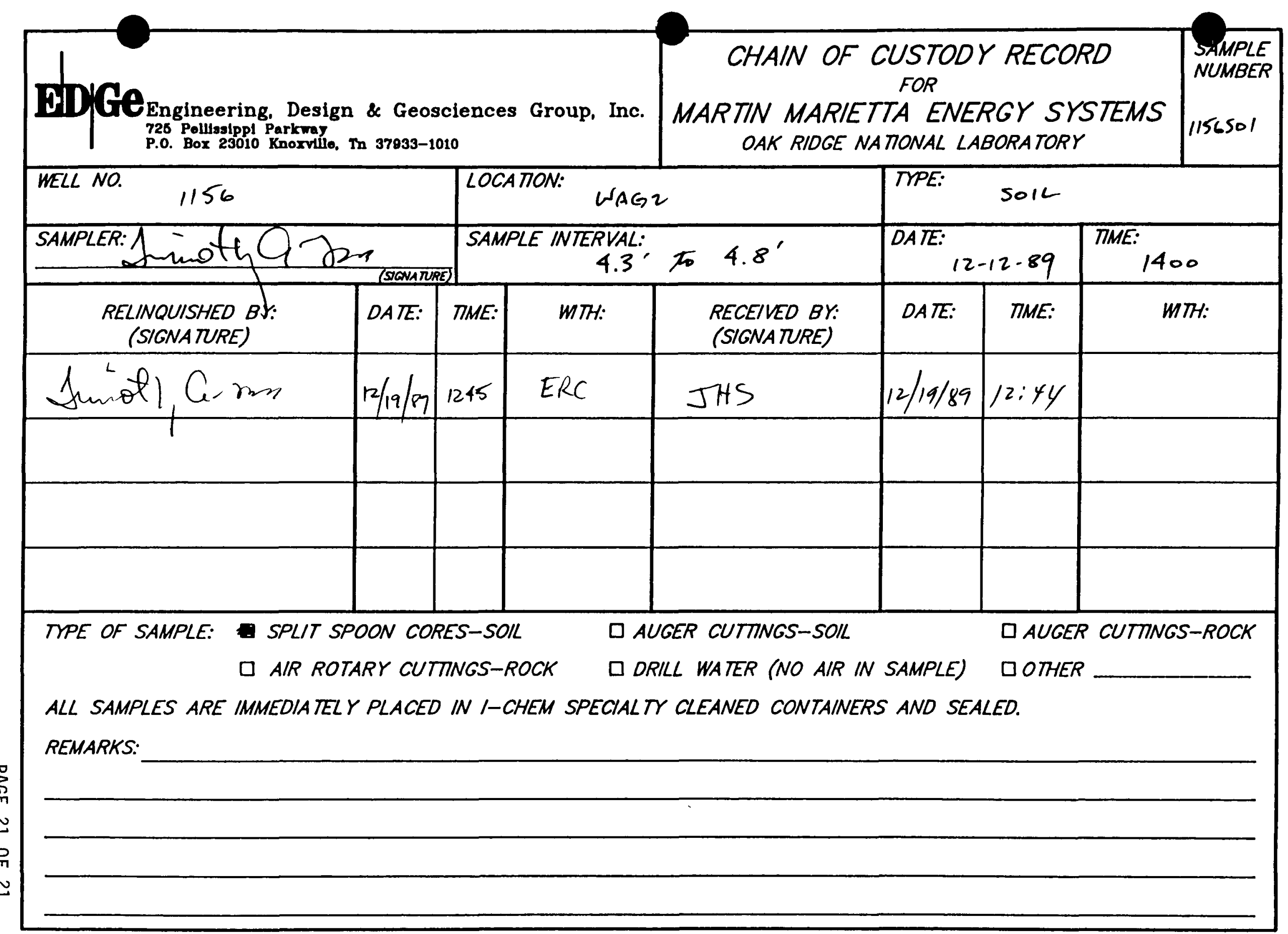


Appendix B

Operating Instructions for Handling Water and Cuttings from Well Drilling and Development of Groundwater Quality

Monitoring Wells 
OPERATING INSTRUCTIONS FOR HANDLING CUTMINGS AND WATER FROM FROM VELL DRILLING AND DEVELOPLEMT OF THE

GROUNDWATER QUAIITY KONITORING WELLS

Prepared by

J. A. Greene 


\section{PROCEDURE REVIEW AND APPROVAL Form}

Environmental and Health Protection Division

Operating Instructions for Handing Cuttings and hater from

Procedure Tille hell Drilling and Development of the Groundwacer Cualitv

Procedure No. Monitoring Wells

Author

REVIEW AND APPROVALAl m minimum, proceduree ere eporoved by the manager of the Implementine unit and the next hioher level menager. SOPa must be reviewed by oA etalt to

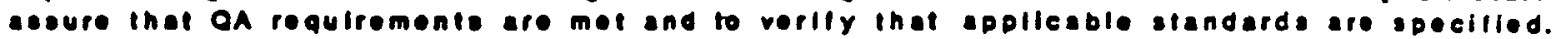
signetures of the epprovera MUST eppear on the liret paoe of each approved piocedure. The required approvere end ine OA reviewer mut ion below.

Approved by:

Aevlewed by:

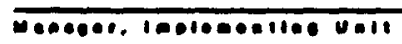

Dete

Hev. No.

Date

In the epeces below Indleate eddilionsl revlews (R) or approvale (A). All reviewers and epprovere muet ign end date inis lorm belore ine procedure can be linaliy appioved.

Il more inan one proecudie le belng reviewed, atteen liet.

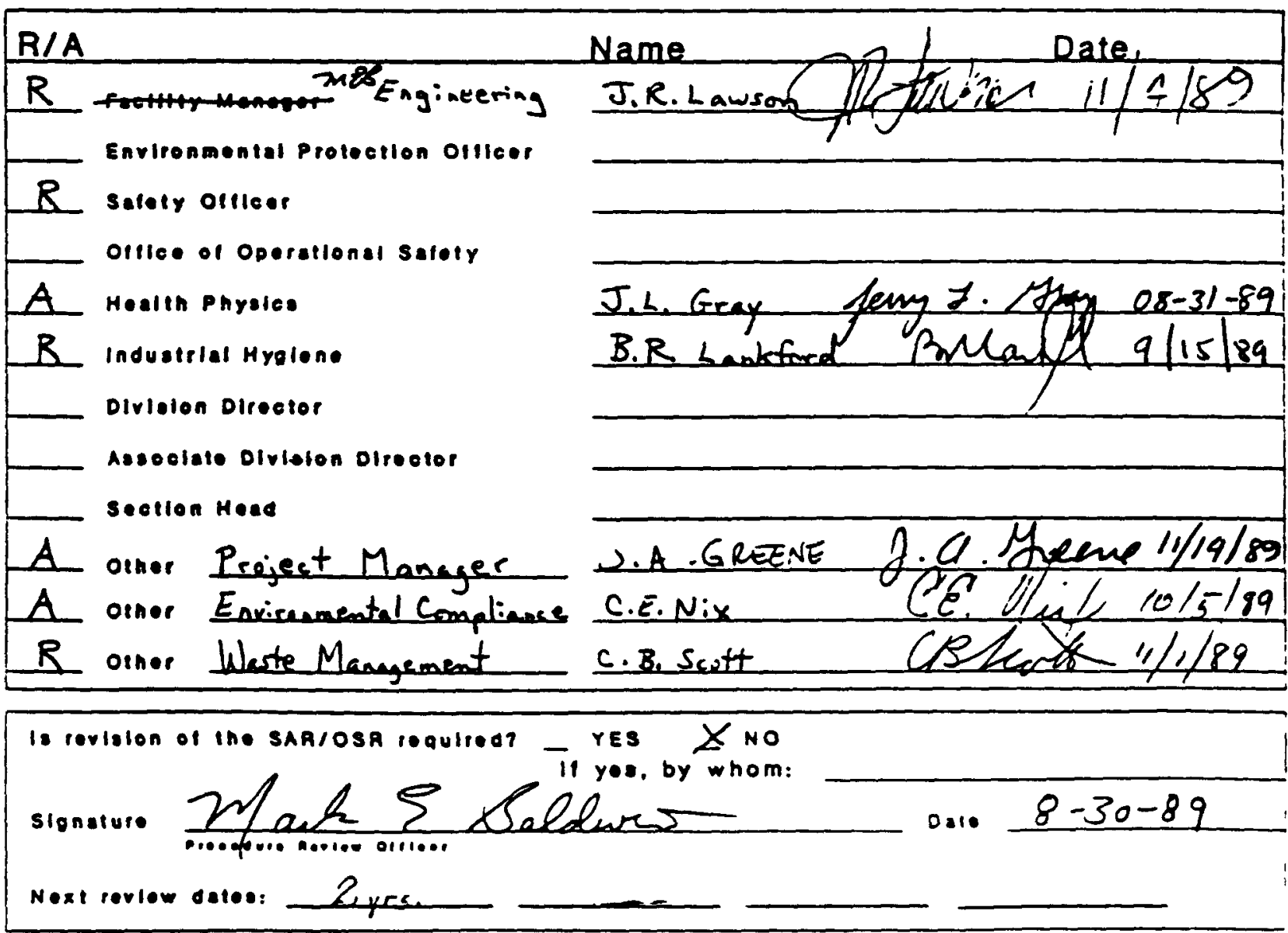

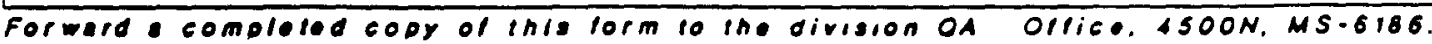


OPERATING INSTRUCTIONS FOR HANDLING CUTTINGS AND WATER FROM

FROY WELL DRILLING AND DEVELOPMENT OF THE

GROUNDWATER QUALITY MONITORING WELLS

\subsection{PURPOSE}

The purpose of this document is to cite the steps that are followed to handle water and soil produced during the installation and development of wells.

\subsection{SCOPE}

This document applies to well drilling and development associated with the Groundwater Quality Monitoring Wells Installation Program at Oak Ridge National Laboratory.

\subsection{REFERENCE}

Health, Safety, and Environmental Protection Procedures for Excavating Operations, ORNL/M-116/R1, Oak Ridge National Laboratory, March 3, 1988.

\subsection{DEFINITIONS}

We11 Ratings. Ratings assigned during the excavation permit cycle by Radiation Protection (RP) and Industrial Hygiene (IH) to indicate the probability of encountering radioactive and chemical contamination, respectively. These ratings are based on historical information or from previous drilling or excavation activity. The ratings are marked on the excavation permits. (RP ratings on permits may sometimes be called "HP'" for "Health Physics." The two designations are interchangeable.) Protective measures required for the three categories are stated in Table 1, "Excavation-classification categories," in ORNL/M-116/Rl. The categories for soll handling are stated in Appendix B, 'Radiological Soil Handling Criteria,"' in ORNL/M-116/RI.

RP Category 1. A rating assigned by RP which indicates that the probability of encountering radioactive contamination is low and that intermitcent monitoring is required by $R P$.

IH Category 1. A rating assigned by IH which indicates that the probability of encountering chemical contamination (1.e., organics) is low and that monitoring is not required by IH. An IH and/or Environmental Monitoring and Compliance (EM\&C) representative will be called in any time chemical or hazardous contamination is suspected.

RP Category 2. A rating assigned by $R P$ which indicates that the probability of encountering radioactive contamination is moderate and that continuous monitoring is required. The RP representative will determine the necessary level of protective clothing to be worn.

IK Category 2. A rating assigned by_IH_which indicates that the probability of encountering chemical contamination is moderate and that respirators must be on-site and ready for use by the workers when 
indicated by the IH or RP representative on-site. Location will be checked periodically with an IH field instrument, such as a Photovac or Organic Vapor Organizer (OVA).

$R P$ Category 3. A rating assigned by $R P$ which indicates that there is a high probability of encountering radioactive contamination. Therefore, continuous monitoring by an RP representative is required, and protective clothing must be worn. In addition to the training listed above, workers must have successfully completed the Category 3 Driller Training course that is administered by Environmental and Health Protection Division (E\&HP) personnel.

IH Category 3. A rating assigned by IH which requires the workers to wear respirators as a minimum. Additional protection deemed appropriate by IH will be designated for each location. Continuous monitoring by IH personnel is required.

Training Requirements. Training requirements for workers include the Basic Radiation Trafning administered by E\&HP personnel and the $40 \mathrm{~h}$ of training required by the Superfund Amendment Reauthorization Act (SARA) through a company-approved course. There is an additional training course required for Category 3 drilling.

Air rotary containment box. A box specially designed to contain the cuttings and water that are blown from the borehole during air rotary drilling. The box is equipped with a high-efficiency particulate air (HEPA) filter to prevent particles that possibly contain contaminants from being dispersed into the air. Air rotary drilling is generally used only for drilling into bedrock.

Auger pan. A metal catch pan with a hole cut in the middle. The pan surrounds the borehole and contains soil cuttings as they are augered up.

Proper On-Site Disposal. Disposal of noncontaminated soil and water produced from work on a well at a location near the well that is not openly visible to the public and has no risk of causing erosion or direct discharge into a stream. The construction engineer (CE) will indicate to the drillers which areas are acceptable for on-site disposal. The $\mathrm{pH}$ will have been checked and adjusted to the 5-to-9 range before releasing. This precise definition is intended wherever this term is used in this procedure.

Proper Contaminated Waste Disposal. Generally, radioactively contaminated soil will be packaged in drums and tagged by the RP representative for disposal by ORNL Waste Operations. However, Category-2-level soil may be used on site as backfill in remote areas when covered by $1 \mathrm{ft}$ of noncontaminated soil as stipulated in ORNL/M. $116 / R 1$. The $C E$ will specify to the drillers when a well location has been approved by EM\&C for on-site dispesal of contaminated soll. This definition is intended wherever this term is used in this procedure. 
Temporary Drilling Equipment Cleaning Facllity. An outdoor area located in Melton Valley for steam cleaning of drill rigs and associated equipment, referred to as the steam cleaning area.

Contalnment Box Holding Pit. A lined pit at the Temporary Drilling Equipment Cleaning Facility. The contents of the pit will be sampled and tested for gross alpha, gross beta, pH, and tritium*, before being released through a silt fence. Contents that have a potential for containing hazardous materials (1.e.. IH Category 2 and 3 locations) will have been checked with an IH field instrument before being released into the pit.)

Steam Cleaning Pits. Two lined pits at the Temporary Drilling Equipment Cleaning Facility that collect runoff from the stean cleaning operations. The contents of the pits will be sampled and tested for gross alpha, gross beta, pH, and tritium*, before being released through a silt fence. Contents that have a potential for containing hazardous materials (i.e., IH Category 2 and 3 locations) will have been checked with an IH field instrument before being released into the pit.)

\subsection{RESPONSIBIIITIES}

5.1 Radiation Protection Personnel monitor and determine the presence of detectable radioactive contamination in drill cuttings during well-drilling activities. They provide guidance to ensure that exposures to the workers, public, and environment are kept as low as reasonably achievable. They also provide radiation monitoring during the precursory cleaning by the drillers.

5.2 Well-Drilling Personnel perform well drilling and completion activities. They package soll and water in appropriate containers and transport it, if necessary; perform precursory cleaning of low-level contaninated equipment; and perform cleaning of equipment between the drilling of each well.

5.3 EDGe Hydrogeologists observe all crucial well installation activities and record data for all boreholes drilled. They do a visual inspection of the cuttings produced during augering and note any unusual occurrences and obvious deleterious material encountered during the drilling process. They check the cuttings and water with a Photovac or OVA or similar instrument and check $\mathrm{pH}$ of water when necessary.

5.4 Construction Engineer serves as the field contact and provides guidance to the drillers during field activities.

\subsection{PROCEDURE}

\subsection{EXPLANATION OF THE WELL RATING SYSTEM}

Each well is assigned a rating by RP and IH before drilling begins. Because additional information is gained during drilling, 
well ratings may be changed by $R P$ and $I H$ as the work progresses. A lower RP Category rating will be changed to a Category 3 rating upon encountering radioactive contamination within the Category 3 range defined in ORNL/M-116/Rl. Likewise, an IH Category 3 may result if chemical contamination is detected in a well with a lower rating. The RP and/or IH representative on site will notify the on-site personnel when conditions warrant a rating change. Any additional actions or modifications in protective clothing required by the rating change will be executed at that time. The change will be documented immediately by the on-site hydrogeologist in the well data package and as soon as possible by the RP and/or IH representative by a signed written statement stating the well number, the old and new ratings, and the rationale supporting the change. The statement will be sent by the RP and/or IH representative to the Construction Engineer (CE) for filing with the original excavation permit. A copy will be sent to the RAP Well Installation Manager by the CE.

A well category also may be changed frow a higher rating to a lower rating. For example, if no contamination is encountered while drilling a Category 2 or 3 well, it may be changed to a lower rating after drilling to a certain depth or for development purposes, depending on the history of the area. The documentation procedure stated above for an increase in rating must also be followed for a decrease in rating.

\subsection{CATEGORY 1 WELLS (RP OR IH)}

\subsubsection{Category 1 Drilling}

\subsubsection{Category 1 Auger Cuttings}

a. Auger cuttings will be collected in a catch pan.

b. An RP representative will scan the cuttings intermittently to check for radioactive contamination. Cuttings will be inspected for any unusual discoloration or odor by the hydrogeologist.

c. If there is no contamination detected, proper on-site disposal or disposal at the steam cleaning area will be done.

\subsubsection{Category 1 Air Rotary Drilling}

a. Cuttings will be collected in a containment box.

b. When the containment box is full, one of the following will be done to empty cuttings and/or decant water from the containment box:

$$
\text { proper on-site disposal. }
$$


(2) disposal at the containment box holding pit.

\subsubsection{Category 1 Well Development}

6.2.2.1 Water removed from the well will be contained in drums.

6.2.2.2 The $\mathrm{pH}$ of the water will be measured and will be adjusted to be between 5 and 9 by the $C E$ if it is above or below that range.

6.2.2.3 Drums of water will be discarded by proper on-site disposal or disposal at the stean cleaning area will be done.

\subsection{CATEGORY 2 WELLS (RP AND IH)}

\subsubsection{Category 2 Drilling}

\subsubsection{Category 2 Auger Cuttings}

a. Auger cuttings will be collected in a catch pan.

b. An RP representative will scan the cuttings continuously to check for radioactive contamination. Cuttings will be inspected for any unusual discoloration or odor and tested with a Photovac or OVA by the hydrogeologist for presence of RCRA materials.

c. If there is no contamination detected, proper on-site disposal or disposal at the steam cleaning area will be done.

d. Cuttings will be contained in drums if contamination is detected. Proper disposal will be arranged by Martin Marietta Energy Systems through Waste Operations.

\subsubsection{Category 2 Air Rotary Drilling}

a. Rock cuttings and drill water will be collected in a containment box.

b. When the containment box becomes full, the RP representative will perform a wet towel smear to detect the presence of radioactive contamination. An inspection for unusual discoloration or odor and tests with an OVA will be conducted for the presence of RCRA materials by the hydrogeologist. 
c. If no contamination is detected, one of the following will be done to empty cuttings and/or decant water from the containment box:

$$
\text { proper on-site disposal. }
$$

(2) disposal at the containment box holding pit.

d. If contamination is detected by the rests, arrangements will be made by Martin Marietta Energy Systems through Waste Operations to properly dispose of the water. Further laboratory testing of the box contents may be done.

\subsubsection{Category 2 Development}

\subsubsection{Water removed fron the well will be contained in drums.}

6.3.2.2 When the drums are ready to be emptied, the RP representative will perform a wet towel smear to detect the presence of radioactive contamination. An inspection for unusual discoloration or odor and tests with an OVA will be conducted for presence of RCRA materials by the hydrogeologist. The $\mathrm{pH}$ will be adjusted if necessary.

6.3.2.3 If no contamination is detected, the water will be discarded by proper on-site disposal or disposal at the stean cleaning area will be done.

6.3.2.4 If contamination is detected by the tests, arrangements will be made by Martin Marietta Energy Systems to properly dispose of the water. Further laboratory testing may be done.

\subsection{CATEGORY 3 WELLS (RP AND IH)}

\subsubsection{Category 3 Drilling \\ 6.4.1.1 Category 3 Augering}

a. When a well is classified as an RP Category 3 or an IH Category 3, continuous monitoring will be required by RP and IH. Wearing of respirators will be required. Cuttings will be inspected for any unusual discoloration or odor. Tests for chemical contamination (i.e., organics) will be performed with IH field instruments by an IH representative for IH Category 3 wells. Specially trained personnel will be required to do the drilling. 
b. If no contamination is detected by RP or IH while augering through soil to bedrock, a rating may be changed by RP or IH to a Caregory 2 depending on the depth, the type of contamination expected, and the history of the area.

c. If contamination is detected during augering, cuttings will be drummed. Proper disposal of all cutrings and water will be arranged by Martin Marietta

Energy Systems.

6.4.1.2 Category 3 Air Rotary Drilling

a. Rock cuttings and drill water will be collected in a containment box.

b. When the containment box becomes filled with water and/or curtings, a sample will be collected by EM\&C and will be tested by the Analytical Chemistry Division for gross alpha, gross beta, tritium*, for an RP Category 3. If it is an IH Category 3, the IH representative on-site will determine which (if any) laboratory testing is necessary for chemical contaminants.

c. Proper disposition of the containment box contents will be decided by consensus of E\&HP, the IH or RP representative, EMEC, and the CE, based on the results from Analytical Chemistry Division of the above tests.

\subsubsection{Category 3 Development}

6.4.2.1 Water pumped from Category 3 wells will be contained in drums. Samples will be collected by EM\&C and will be tested by Analytical Chemistry Division for gross alpha, gross beca, tritium,, and pH. It will be tested with IH field instruments by IH representatives for the presence of RCRA materials.

6.4.2.2 A decision based on the test results will be made between E\&HP and Engineering whether to continue development.

\subsection{BOREHOLE CLEANING}

When sludge and water have accumulated in the bottoms of boreholes drilled in soil, the boreholes must be cleaned out prior to setting casings. A decision based on the location of the borehole and its rating will be made between the RP and/or IH

representatives whether the sludge and water from the borehole must be contained in a drum. Water and sludge from a Category 2 well will be drummed, and a wet towel smear will be done by RP to 
determine proper disposal of the drum contents. Laboratory testing of the drum contents for gross alpha, gross beta, tritium*, and $\mathrm{pH}$ will be done if recomended by the RP or IH representative. Water and sludge removed from an RP Caregory 3 well will be drumed, and laboratory testing will be done for gross alpha, gross beta, tritiumt, and pH. EM\&C will be consulted to determine proper disposal based on the test results. Further laboratory testing to determine actual contaminants will be done if recommended by EM\&C.

-Testing for tritiun will be done for wells locoted in areas there tritiun contanination is suspected. This decision will be made between RP and EMRC. 


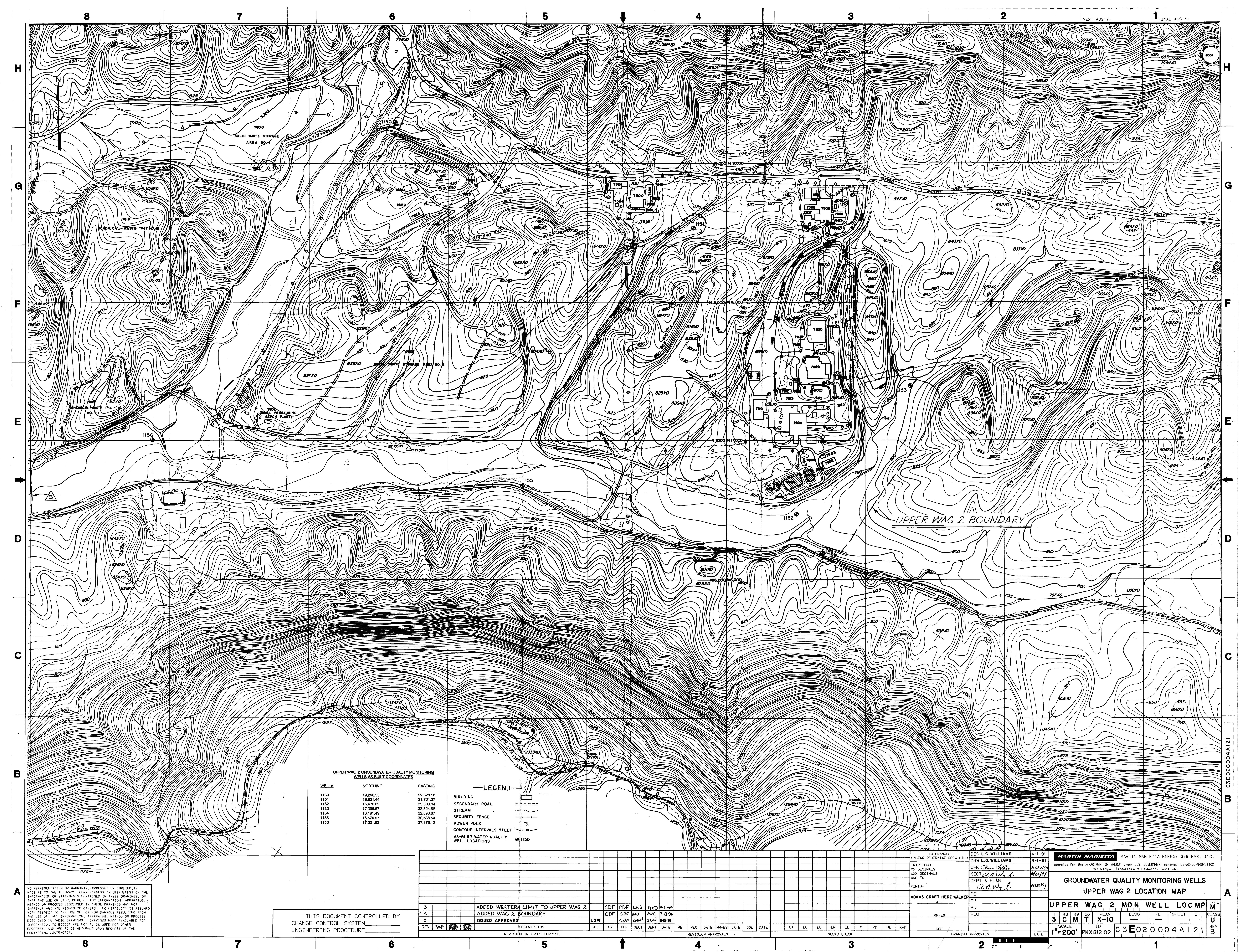




\section{DISTRIBUTION}

1. F. P. Baxter

2. H. L. Boston

3. T. A. Early

4. M. L. Ebers

5. S. Herbes

6. R. H. Ketelle

7-9. D. M. Matteo

10. J. A. Mortimore

11-12. P. T. Owen

13. P. A. Schrandt

14. M. M. Stevens

15. P. S. Wood

16-18. ORNL ER Document Management Center

19. ORNL Patent Section

20-22. Central ER Document Management Center

23. Laboratory Records Department

24. Central Research Library

25. Office of Assistant Manager for Energy Research and Development, DOE Oak Ridge Operations Office, P.O. Box 2001, Oak Ridge, TN 37831-8600

26-27. Office of Scientific and Technical Information, P.O. Box 62, Oak Ridge, TN 37831 